\title{
A HISTORY OF THE \\ BRITISH DOMINIONS \\ BEYOND THE SEAS
}

AVARY H. FORBES M. A.

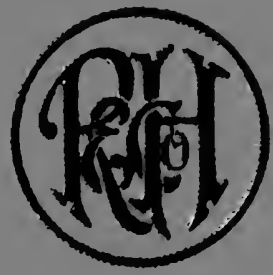

RALPH, HOLLAND \& CO. 


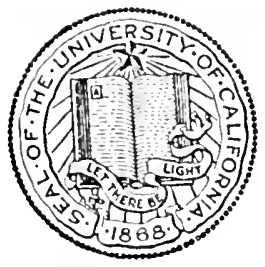

THE LIBRARY

OF

THE UNIVERSITY OF CALIFORNIA LOS ANGELES 


$$
\begin{aligned}
& \text { 피 } 1 \%
\end{aligned}
$$

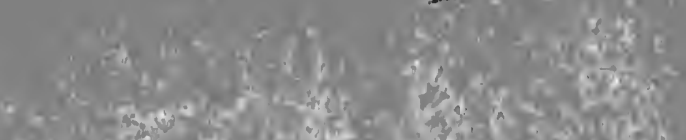

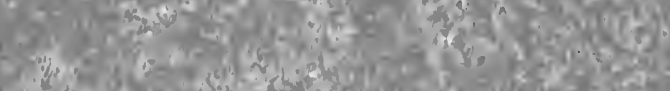

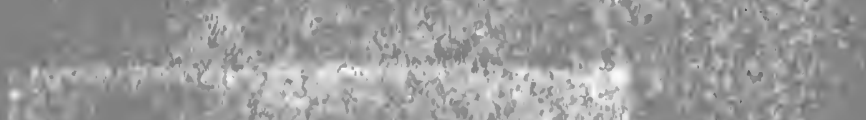

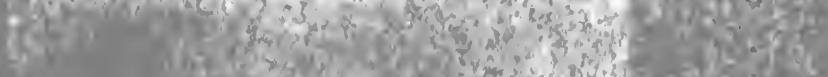
it

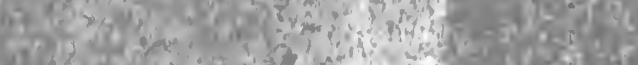

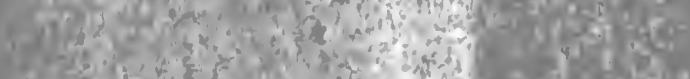

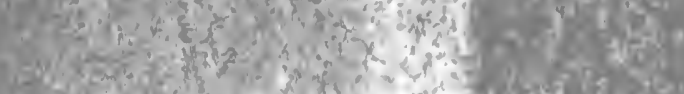

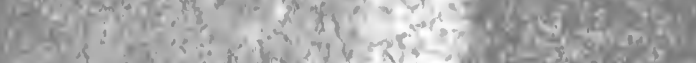

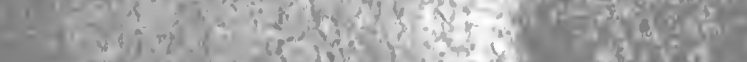
$1 \% \sin 20$ a

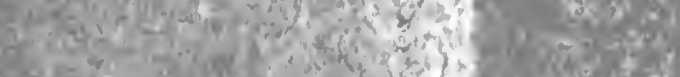

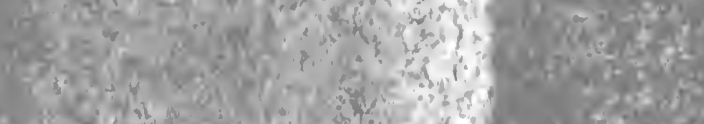
N.

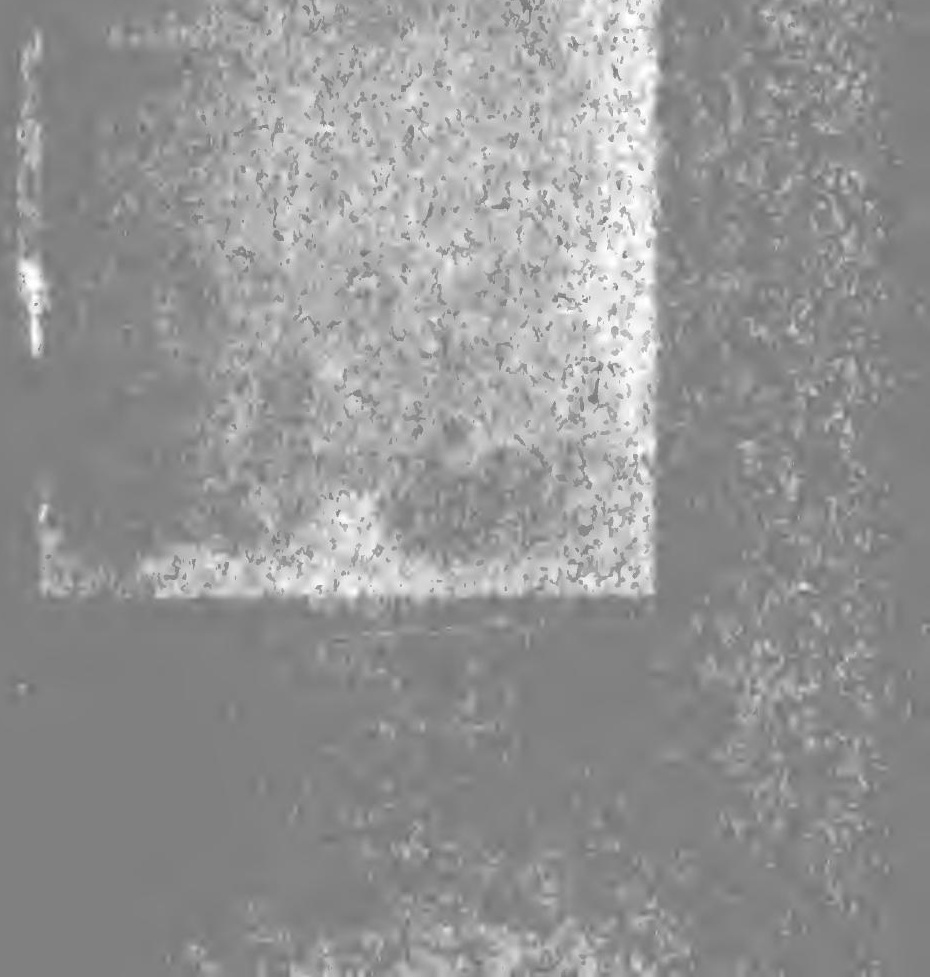


(1)

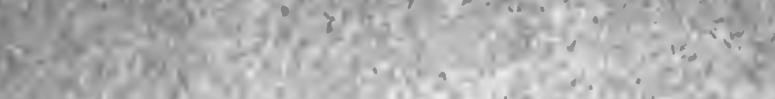

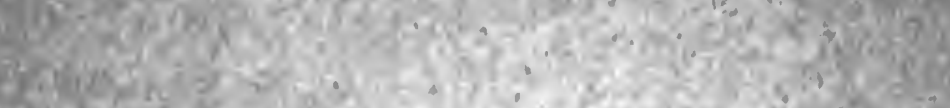

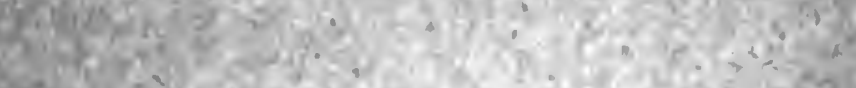

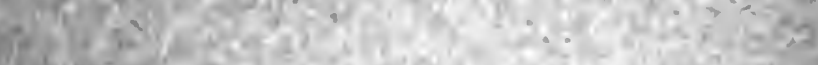

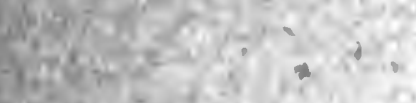

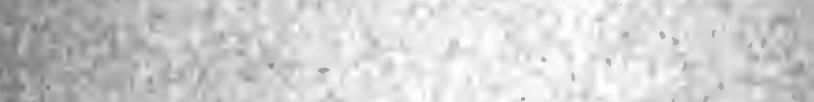

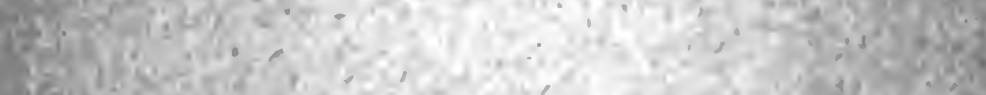

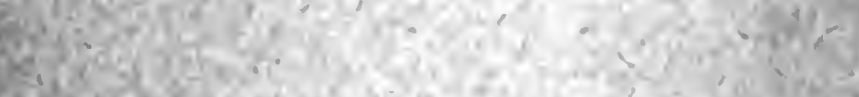

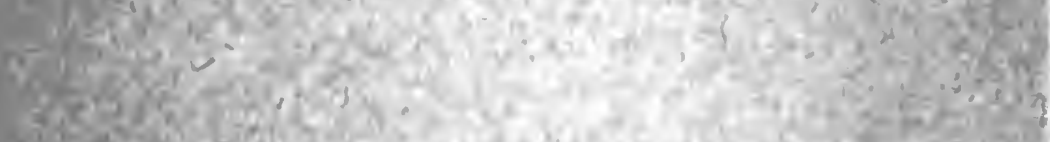
4.

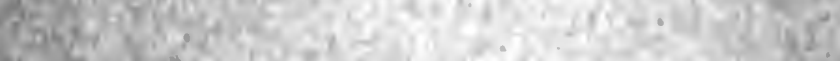
104
10 2.

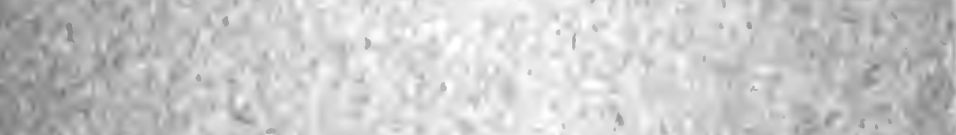

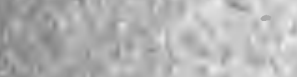

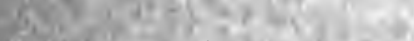

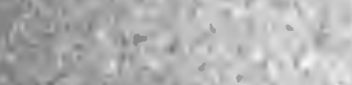

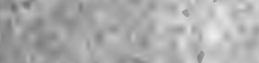

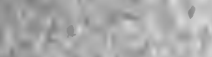

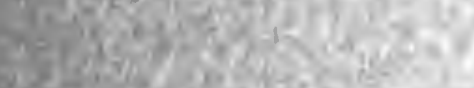

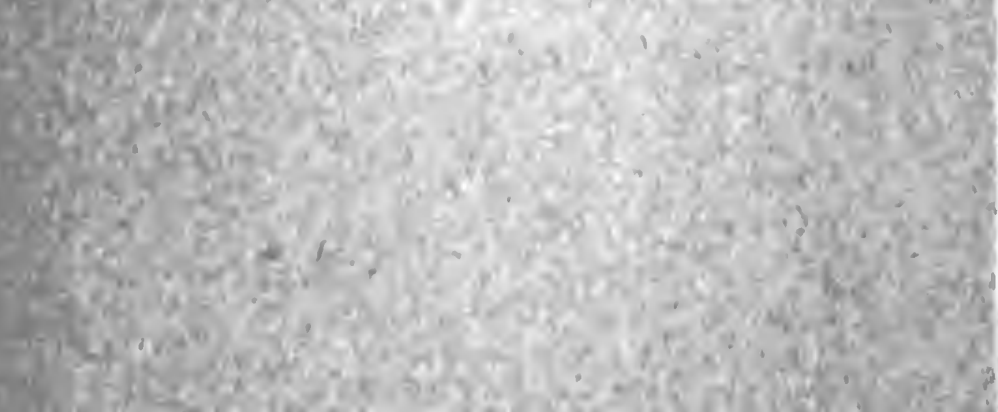


<smiles>[3H]</smiles> 


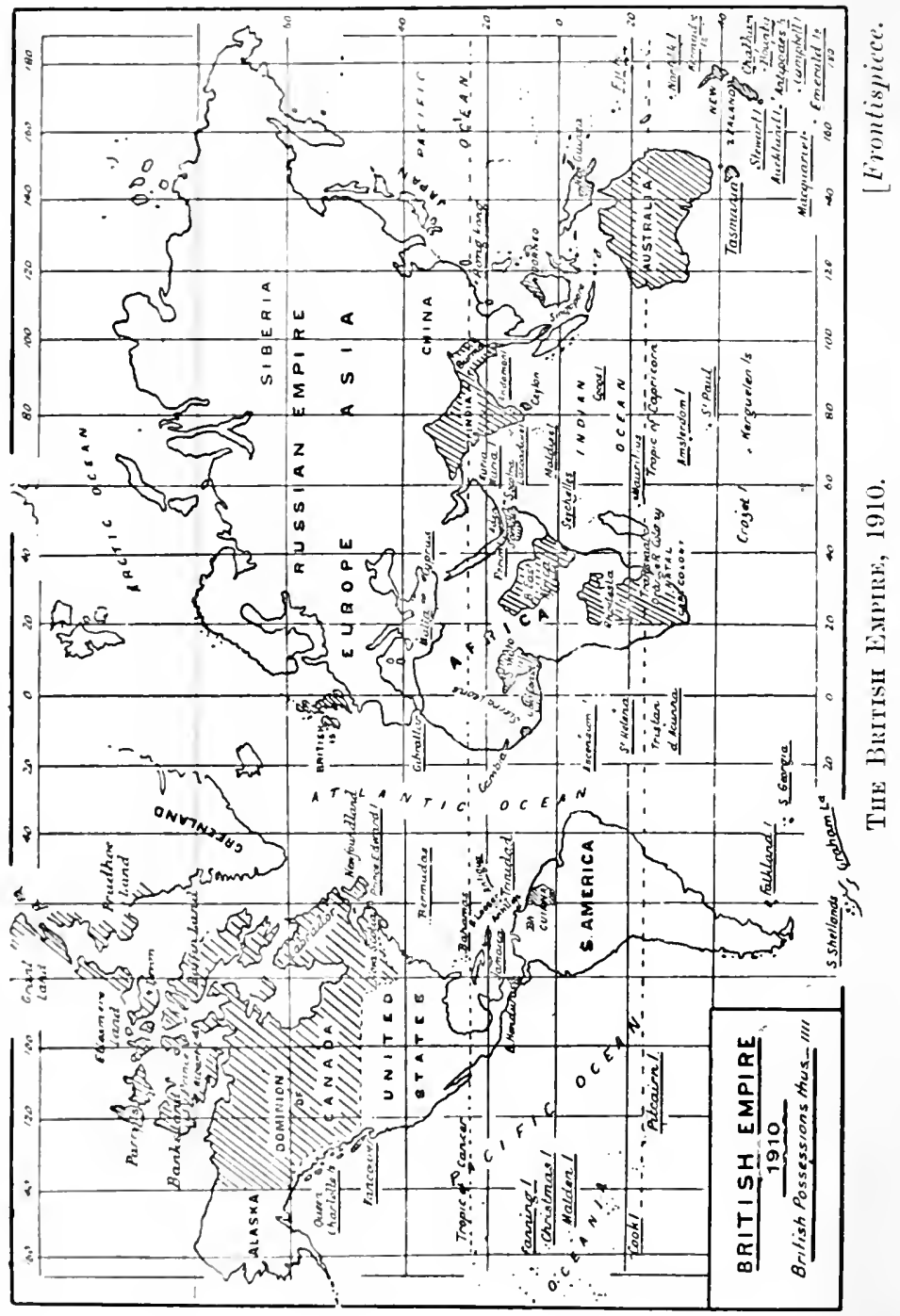




\title{
BRITISH DOMINIONS
}

\section{BEYOND THE SEAS}

\author{
(1558-1910).
}

EDITED BY

AVARY H. FORBES, M.A. (Barrister-at-Law),

GOLD MEDALLIST IN EXgLISH LITERATCRE, AND SENIOA MODERATOR, CNIVERSITY OF DUUbiN ; AUTHOR OF "CERTIFICATE HISTORY (1763-1815)," "A CONCISE HISTORY OF EUROPE," "ESSAYS AND HOW TO WRITE THEM," "History of ENGLAND (1688-1820)."

\section{วờัon :}

Ralph. Holland \& Co., Temple Chambers, E.C. 


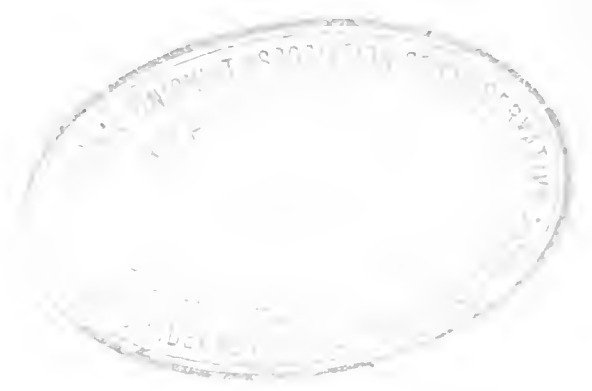

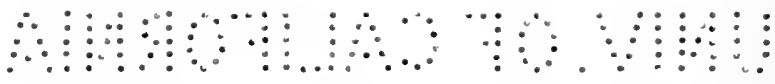

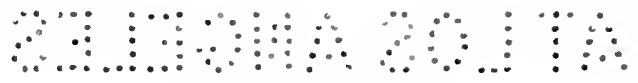
$\because \because \because \therefore \because \because \because \vdots: \vdots \vdots$ 


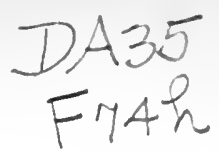

\section{PREFACE.}

Wrrn some slight emendations this volume embodies "Clough's Expansion of the British Empire (1558-1858)," and continues the same down to 1910. The book treats of the origin, growth and development of the Colonial Empire of Great Britain, in. eluding thereunder not only the great depen lency of India, but all the recently acquired Protectorates-such as those of Nigerii and Nyassaland-and leaseholds or "contingent" holdings such as Cyprus an 7 Weihaiwei. The last fifty years have been exeedingly aetive in Colonial growth, both as regards territorial expansion and federal consolidation, and no pains have been spared to obtain the liatest and most reliable information respecting these great advances.

The present volume is plentifully supplied with Maps, as well as 'Tables-all brought up to date-illustrating the up. building of the Empire, and biographical and glossarial Appendices have likewise been added.

Many of our South African possessions have undergone frequent experimental changes, being declared, at one time protectorates, at another time dependencies of a larger state, and anon separate colonies or protectorates again. This will account for some seeming inconsistencies in the dates or descriptions in the following Tables; but great care has been taken to make the matter as aceurite and clear as possible.

Every effort has also been made to keep up with the spelling vagaries of the day; but perfect suceess in this respect is not to be looked for, sinee, before these sheets are dry, the orthography of many geographieal names will probably have altered!

Upper Tooting, 1910.

A. H. F. 
Digitized by the Internet Archive in 2008 with funding from Microsoft Corporation 


\section{CONTENTS.}

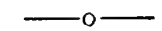

CHAPTER.

PAGE.

$\begin{array}{llllllll}\text { Introluctory } & \ldots & \ldots & \ldots & \ldots & \ldots & \ldots & 13\end{array}$

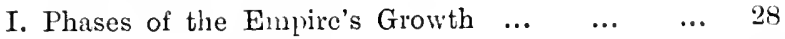

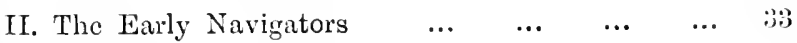

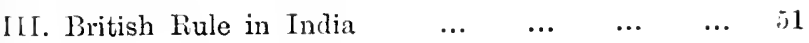

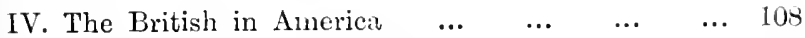

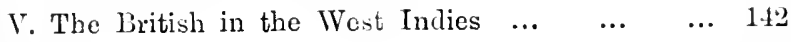

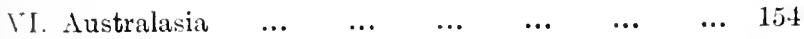

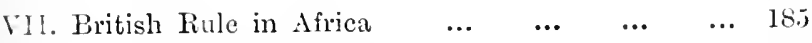

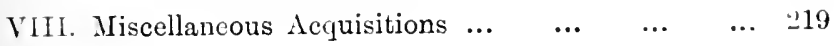

\section{Appendix-}

$\begin{array}{llllllll}\text { I. Biographical } & \ldots & \ldots & \ldots & \ldots & \ldots & \ldots & 225\end{array}$

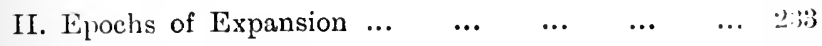

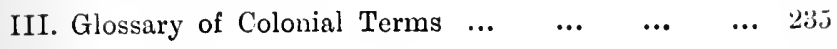




\section{MIAPS AND TABLES.}

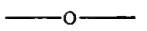

\section{MAPS.}

PAGE.

The British Empire ... $\quad \ldots \quad \ldots \quad$... $\quad$ Frontispiece.

The World, to illustrate Commerce and Diseovery $\begin{array}{lllllll}\text { under Queen Elizabeth } & \ldots & \ldots & \ldots & \ldots & 35\end{array}$

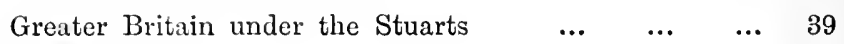

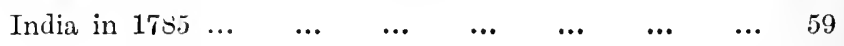

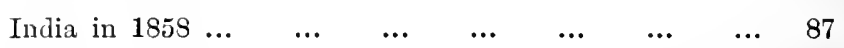

The Ameriean Colonies at the Beginning of the Seven

$\begin{array}{llllllll}\text { Years' War } & \ldots & \ldots & \ldots & \ldots & \ldots & \ldots & 112\end{array}$

The Ameriean Colonies at the End of the Seren

$\begin{array}{llllllll}\text { Year's' War } & \ldots & \ldots & \ldots & \ldots & \ldots & \ldots & 117\end{array}$

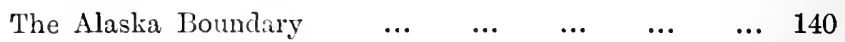

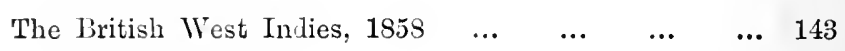

$\begin{array}{llllllll}\text { South Afriea } & \ldots & \ldots & \ldots & \ldots & \ldots & \text { (to face) } & 192\end{array}$

British East Africa Protectorates ... ... $\quad$ (to face) 200

$\begin{array}{lllllll}\text { British IVest Africa } & \ldots & \ldots & \ldots & \ldots & \text { (to face) } & 208\end{array}$

$\begin{array}{llllllllll}\operatorname{Burma} & \ldots & \ldots & \ldots & \ldots & \ldots & \ldots & \ldots & \ldots & 220\end{array}$

$\begin{array}{llllllllll}\text { Borneo } & \ldots & \ldots & \ldots & \ldots & \ldots & \ldots & \ldots & \ldots & 222\end{array}$

British New Guinea (Papua) $\quad \ldots \quad \ldots \quad \ldots \quad \ldots \quad \ldots \quad 222$

\section{TABLES.}

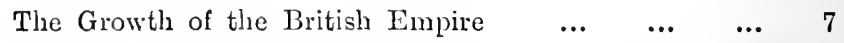

The Growth of the British Empire (Chronologieal) $\ldots . \quad 11$

The Growth of British liule in India $\ldots . \quad \ldots \quad \ldots \quad$ 105 


\section{CIIRONOLOGICAL TABLE ILLUSTIATING}

THE:

\section{Growth of the British Empire.}

1583. Newfourdlana.

1600. St. Helena.

1605. Barbadocs.

1609. Bermudas.

1631. Gambia. (Abantoned a"d re-settled in 1919.)

1632. Antigui, Montserrat, and the Leeward Islands

1655. Jamaica.

1661. Gold Coast.

1661. Barbuda.

1666. The Virgin Islands.

1666. Bahamas.

16:8. 'Turks and Caicos Islands.

1704. Cibla!tar.

1713. New Brunswick.

Prince Edward's Island.

Nova Scotia.

1759. Canalia. (Ontario and Qtiebec.)

1763. St. Vincent, Tobago, Gruada, Dominica.

The Windward Islands.

1783. St. Christopher, Nevis.

1787. Sierra Leone.

1787. New South Wales.

1795. Ceylon.

1797. Trinidat.

1798. Honduras.

1800. Malta and Gozo.

1803. British Guiana, st. Lucia.

1806. Cape Colony.

1810. Mauritius.

1815. Ascension.

1818. Gambia, 'Tristan d'Aca uha.

1825. Tasmania. 
1829. West Australia.

1632. Falkland I sla:ds.

1836. South Australia.

1838. Aden.

1840. New Zeaknd.

1843. Hong liong.

1844. Natal.

18:5. Labuan.

1851. Vietoria.

1855. Perim.

1857. Feeling Islands.

1858. Straits Settements.

1858. British Columbia.

1858. India formally placed under the British Crown.*

18j9. Queensland.

186t. Lagos.

1862. Griqualand East.

1868-1884. Basutoland.

1870. Manitoba.

1871. Griqualand West.

1871. Fiji Islands.

1877. West Paeifie Islanãs.

1878. Cyprus.

1881. North Borneo.

1884-1853. Nigeria Protectorate.

1851. British New Guinea (Papuz).

188j. Bechuanaland.

1886. Upper Buma.

1883-1830. British East Africa.

1837. Zulnland.

1887. Somaliland Protectoraie.

1888. Nyassaland.

1888. Salawak.

1888. Ihodesia.

1888. Brunei Protectorate.

1890. Zanzibar Protectorate.

1894-1896. Uganda Protectorate.

1898. Weihaiwei.

1902 'Transvaal.

1902. Orange River Colony.

1905. Aluerta, Saskatchewan.

- Fur Thble illustrutiny the grouth of British rule in India, see p. 10.5. 


\section{A HISTORY OF THE \\ BRITISIH DOMINIONS}

\section{BETOND THE SEAS.}

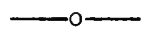

The foundation of Britain's vast colonial empire forms a chapter of absorbing interest in the history of civilisation. Indeed, it might well be asserted that the spread of the Anglo-Saxon people forms the feature of the present age, in that it has, more than any other cause, influenced the destinies of mankind and affected the happiness of the human race. Equally momentous is the question as to the relations which are to obtain between the mother country and her various dependencies. To the effectual solution of this question it may be of value to consider briefly some few of the causes which have brought about the success of the British colonies rather than those of those rival nations, which, though first in the field, have now been hopelessly outdistanced.

A colony may be defined as the planting of a portion of the inhabitants of one country on the territory of another. In ancient times the foundation of colonies was the natural outcome of the growth of the population

Ancient

Colonies. and of the ineritable law of food necessity. As a nation grew, its population became too great both for its bounds and for its fool supply. The readiest solution of the difficulty which thus periodically 
occurred was to be found in conquest. A population which had developed to a burdensome pitch, found its natural outlet in an inroad upon some neighbouring people, more richly endowed with territory and better supplied with food. Hence, one great reason for the anxiety of ancient peoples to breed a race of soldicrs.

Thus it was formerly in Greece and Rome. Two noteworthy differences, however, existed between the colonies of these great nations of the ancient world. Those of Grecce were all planted at a distance from the parent state and became, for the most part, independent countries, while those of ancient Rome, planted first in the immediate vicinity of the great city itself, gradually spread throughout Italy into the adjacent countries, thus forming a vast territory of which Rome was the centre and of which the various states were all held in the strictest subjection to the central authority.

Thus in very early times we see two distinct types of colonies. The types persist throughout the history of colonisation, and it is on the conflict between them that that history turns.

As we approach modern times there rise in long array the fruits of the energy and enterprise of the greatest nations of the civilised world. The thirst for discovery which prompted men to penetrate into hitherto unexplored

Modern

Colonisation. regions and to brave dangers, all the more terrifying because unknown, was not con. fined to any one nation. Five great European peoples shared the risk and divided the glory. Spaniard, Portuguese, Dutch. man, Frenchman and Englishman each attempted to plant his country's flag and extend her dominions among the barbarous nations of the world, and each, in turn, achieved pre-eminence in the endeavour to found a colonial empire. New Spain, New Portugal, New Holland and New France all bad their day. Bnt all these once great empires have fallen 
or have dwinciled into nothingness or insignificance. England, alone, has succeeded in firmly establishing her dominion, and the history of her progress should, in displaying the reasons for this, furnish a clue to the policy on which her future relations with the vast dependencies thus called into being should be based.

Early attempts at colonisation were doubtless due, in great measure, to the caprice of adventurers, the greed of traders and the despairing efforts of broken men to repair their fortunes, or

Reasons for

Colonisation.

of public spirited ones to escape the incidence of unjust laws or to free themselves from the yoke of civil or religious oppression.

At other times they have resulted from the determination of the goverument itself to further commerce, provide an outlet for the surplus population or to secure a convenient means of disposing of its convieted prisoners, or yet again to guard its other possessions from attack or to maintain the route to them in time of war. In each ease, whether the settlewent was originally a trading station, an agricultural eolony, a penal settlement or a military outpost, the eourse of after events was much the same. The original settlement speedily became the centre of an enterprising population, tending its tlocks and herds, tilling the soil, or developing the natural resources of its new home.

It should, however, be remembered, that a colony in the strict sense of the word can only be maintained in such parts of the world as afford Europeans a permanent houne. Such a place will grow the cereals which form so

Agricultural and

Plantation Colonies. great a part of the diet of the white man, will admit, without serious detriment to health, of the most arduons and sustained labour on his part, and will, moreover, admit of his rearing a family in full health and vigour. Where such conditions do not prevail, the agrienltural colony gives way 
Defore the plantation, upon which the settler, at more or less peril to health, if not to life, remains until he has won a sufficient competence to enable him to return to Europe and to the family, from which the nature of the climate has necessitated his parting. In such a colony white labour is all but unattain. able, and the population divides itself into aliens and natives, the former the masters, and the latter,- the original owners of the soil-their servants or slaves.

The history of modern colonisation fitly begins with the first of the Spanish settlements in Anerica. True the early Spanish adventurers were hardly to be termed colonists in the proper sense of the word. They sought but Now Spain. to satiate the thirst for wealth excited by the stories, current aniong the mariners, of the riches of the New World. Their daring was of the most extraordinary type. Indeed they were no less famous for their courage and hardihood than they were notorious for their cruelty. Their names stand imperishably upon the roll of fame: they are no less indelily inscribed upon that terrible record of gold-hunger and blood-lust that caused Christendom to thrill with horror at the "devildoms of Spain." But these adventurers made no attempt at colonisation. The country drained of its floating wealth, they sought other and more profitable spheres of industry. To them succeeded the plariter, the missionary and the governor from Europe. The missionaries brought the refining influences of Christianity to bear upon the natives, and the Home Government insisted upon such measures as would ensure that the colonies were, at least, decently governed.

But the planter and the adventurer had one great feature in common. Each desired to exploit the new country for his own benefit. The planter desired merely to obtain a competence with which to retire to his own land, and to this end he sought to bring the wretched aborigines under his yoke: wringing unwilling labour from them while he himself battened 
on the riches thus produced. He sought to take everything and give nothing. No home policy, be it never so wise, could make a colony where such principles prevailed, flourish, or could even bolster it from fall. Without individual energy and enterprise there can be no success. The colonist who is to succeed must justify his existence: the colony which is to prosper must give as well as take. The natives were ground down by forced labour and exaction, the country impoverished by the continual drain upon its resources. Nor was the evil less when the planter acted as the agent of a company at home. For a time, it is true, success seemed to follow the settlers. The accumulated riches of the East and West needed only to be tapped, not created. It was only necessary to fit out an expedition and, barring accidents, success was sure. But such success was as ephemeral as easily won. After a time the system failed. The labourer-the wealth producer-grew more and more in importance, while the capitalist grew less and less. Then the decline began and the downfall of the commercial coloniesthose whose riches were exploited by a company from Europe, has been signal.

Nor was the lot of those governed directly by the home government to be preferred. Their rulers, often without the most elementary linowledge of the requirements of the district or the conditions of existence which there prevailed, legislated without sympathy for their desires or comprehension of their needs. Laws, which might have proved entirely beneficial in the old country, here produced nothing but disaster.

Such conditions were fatal, but such conditions nevertheless prevailed everywhere throughont the American settlements of Spain and Portugal. As a result, the colonial bistory of these, the first of the great colonisiug nations, is a record of almost unbroken failure. The loss, by revolt, of the chicf of their colonies at the beginuingr of the nineteenth 
century is, in itself, a proof of their incapacity to rule them wisely. Even in the few that remain, no spirit of loyalty exists such as, for instance, Britain's colonies have shown when the mother country has passed through a time of stress and difficulty. All that they can claim is a reluctant allegiance wrung from the natives by force and maintained by means of a vast military expenditure.

The triumph of Anglo-Saxon colonisation and the cause of the expansion of Britain is largely due to a recognition of these facts. English settlers looked upon a colony as a place where persevering labour might win wealth. They went thither to work, not to enjoy what the natural wealth of the country afforded or what the labour of others had created. Moreover, they believed that a colony could only be administered on the spot, and not governed, machine-wise, by a power thousands of miles away in Europe; a power, moreover, blindly ignorant of the necessities of the settlement and of the conditions of its successful development. Thus each and all of the British colonies eame in time to possess freedom of action, within certain well-defined limits, although the mother country, until the revolt of the American colonies opened her eyes, was still blind encagh to claim the right of regulating both taxation and trade.

Probably another influence tended to the triumph of the English colonies over those of Spain and Portugal-the "insularity" of the Briton, who earried into his new homo all the ideas and tastes of the old, while, on the other hand, Spaniard and Portuguese were adapting themselves, with a fatal facility, to habits and customs prevalent around them, amalgamating with the native population and merging their identity more and more in that of the conquered races.

Thus an English community abroad presonted the eharacteristice of a similar community at home, and Greater Britain 
became not only an extension of the state, like Greater. Spain and Greater Portugal, but an expansion of the nation as well.

Perhaps one of the most valuable lessons which the world has learned from the fall of the colonial empires of Spain and Portugal is that, when the growth of an empire is counter. balanced by no corresponding development of the nation to which it belongs, then the hold of that nation upon the cmpire becomes loosened, its rule artificial, and its tenare precarious. To one portion of the British dominions only does this apply. In the vast dependency of India alone do we find the vast bulk of the nation of other than Anglo-Saxon race. A.ll other parts of the empire are not only ruled by Britons but peopled by settlers of British descent, who are linked to the parent race by ties of common blood, common tastes and feclings, common modes of thought and common religion. It may be objected that in Canada there still exists a remnant of the conquered French; in the Indies, bodies of enfranchised negroes, relics of English pre-eminence in the unholy traflic in human flesh and blood; and at the Cape, both the aboriginal races of Kaffirs and Hottentots and the descendants of their first conquerors-the Duteh; yet the conflict of races in these colonies has presented little real difficulty and the tendency in them is to approximate, year by year, more and more closely to the Anglo-Saxon type. In the two former, indeed, the question of the relations between the settlers of British birth and those of alien origin has been, in great part, solved by the wise adoption of a policy which grants the colonies political frecdom and which sacrifices no jot of their welfare for the advantage of the home government. In the last, the question presents greater difficulties of solution. Yet even here there is little danger of such a rising as that which reft from Spain and Portugal their vast possessions in Central and South America, and, by the foundation of the Central and South American republics and the lingdom of Brazil, 
annihilated New Spain and New Portugal, which, in the fifteenth and sixteenth centurics, bade fair to engross between them the whole of the New World. From that time Spain and Portugal have stood, as regards the rest of Europe, as they did before Columbus made his adventurous voyage and placed the key of the New World in the hands of their rulers.

The Exclusive System.-It should be noted that the greed of gain which plajed so great a part in the establishment of colonies, was equally potent in its effect upon their administration. Whether the scttlement had been the work of individuals, or of a trading company, or of a nation, the prime object of its rulers was to secure all the adrantages possible to be gained from it and to exclude all other individuals, merchants or nations from participating in them. England had been the last to adopt this system. Up to the passing of the Navigation Act unfer the Commonwealth in 1651, the American colonies had been free to trade with whom they pleased. Indeed the liberty to do so was specifically secured to them in their original charters, and as early as 1620 , the Virginias had their warebouses in Midaclburg and Flushing, and did a great trade in tobacco among the Dutch. As England had been the last to adopt this policy of rigid protection, so she was the first to give it up. But meanwhile the rigid adherence of her statesmen to it brought about the destruction of the first New England, and in the empire she had then to found afresh, England reversed a policy whose effects had bcen so fatal in the past, and adopted in its stead that system of virtual self-government under which later colonies have flourished until her empire has become the greatest in the world.

The motives which have led to the growth and development of our colonies have been various. It has depended upon the lust of conquest, awakened either by the desire for enlarged resources or the endearour to protect rights Growth of or territories already acquired; upon the Colonisation. desire, first shown to great purpose by the sea-dogs of Elizabethan times, to attack an enemy's foreign possessions or to cripple his resources in that most vulnerable of points-his commerce; or upon schemes for the disposal of convicted prisoners, whom it was felt undesirable to retain 
longer in the country and whose lawless energies and turbulent tendencies might (it was thought) be turned to good account in a younger civilisation.

The actual growth of the colonies thewse'ves, however, depended in the greatest degree, upon the outflow of the surplus population. Religious persecution in the seventeenth

Emigration. century had much to do with increasing the stream that flowed from England; the revolt of the Ameriean colonies, the downfall of the "exelusive system," and the advent of the "era of independence " rapidly increased it in the eighteenth. As early as 1710, too, the adrocation of emigration was made a direct part of the policy of the government, in the case of distressed agricultural labourers and their families. In the nineteenth century, there has been a vast increase consequent, to a great degree, on the industrial revolution, which, by the increased employment of machinery, threw vast numbers of hands out of work. The improved facilities for navigation and the enlarged knowledge of the resources of the New World have all tended in the same direction. The legislative union of England and Scotland, in 1707 , led to the emigration of large numbers of Scots, to whom the English colonies had hitherto been barred, by their exclusion from the advantages of English trade. Their attempt to set up a separate colony on the Isthmus of Darien had ended in disastrous failure and bitter disappointment. Then, however, the spirit of enterprise, characteristic of the North Briton, led to a vast exodus, and now the Scot is found wherever the fing is planted, prominent alike in business, in agriculture and in polities. Of late years, it is the unlappy Isle of Erin which has been drained of its inhabitants by emigration. To this result many eauses have been contributory. The destruetion, in the last century, of the small holdings for the benefit of the greater landlords, the unjust penal laws and the constant bitterness of religious strife stand among the ehief. The intro- 
duction of the potato and its adoption as the staple food of the country has not been without effect upon emigration. One consequence of the ease with which the potato crop could be cultivated was a general decline in industry, and the failure of that crop left the people without resources and the prey of famine. The two disastrous years, 1846 and 1847 , drove nearly two million Irish to seek a new home beyond the seas.

As a natural result of the overcrowding that exists at home and the increasing difficulty of finding work for the whole population, it has been proposed that a regular scheme should be organised by the government, having for its object the encouragement of emigration and the consequent lessening of pauperism at home. Many serious objections may be made to such a course. The advent of shiploads of useless and indolent paupers is not an event to be looked forward to with pleasure by any country. America, in particular, has strongly set her face against the introduction of such useless additions to her population. Only those who are able and willing to work can find benefit in emigration or contribute to the well being of the country selected. Given these qualities, emigration is in every way desirable, the colonies hold out their hands to welcome the new comer, assist his passage and provide him, if agriculture is his aim, with a grant of land on which he can settle.

The Yalue of the Colonies.-The value of her colonial empire to Great Britain has been immense. She has created vast communities in distant lands, and fostered them until they have matured into settled prosperity, but the reaction of the colonies on the mother country has been no less momentous. It is to her colonies that Britain is mainly indebted for that vast trade which fills her great seaports with their forests of masts and lires them with their miles of docks and wharves, filled with the products of her energy and 
enterprise in every part of the globe-the great harvest of the richest commerce the world has ever known. Commerce, in turn, has called into being her enormous mercantile marine, and, for its defence and by means of the wealth it carries, has created her mighty navy. It has made England the richest of the manufacturing nations of the earth, for from her colonies she draws the material for her industries and every stroke of the miner's pick and every movement of the squatter's shears feeds the fires of her factories or wakes to motion the shuttles of her looms.

It is, in fact, only by means of the resources which she has obtained from her dependencies across the sea, that Britain has been able to dominate the commerce and industry of the world and maintain her position inviolate and secure among the powerful nations with which she is surrounded. Indeed, it may be said that only by the aid of her dependents and by the loyalty and spirit of their people has she been enabled to make the empire what it is. It was largely by the devotion of the Sepoys that India was won: it was, in no small degree, to the efforts of the North American colonists that we owe the conquest of Canada.

The political benefits Britain has derived from the possession of her colonies were most apparent in the early stages of her history. Then it was that suecessive waves of emigration swept from England those bold and unquiet spirits who threatened her peace, and who found, in a new land, that freedom of action and of thought which the settled condition of an established government forbade. Not the least notable of the developments which occurred in this connection was the formation of the penal settlements where some, whose criminal and anti-social tendencies brought them into dangerous conflict with the authorities at home, were converted, aniust new surroundings, into honest and industrious citizens, who, in forwarding their own fortunes, vastly improved the prospects 
of the land of their exile. Such a result is pregnant with meaning for the philanthropist or social economist of to day who seelis a remedy for the poverty and distress which form an ever-present blot upon the richest civilisation the world has seen. The value of colonies as schools for the training of forces for the defence of the empire is equally pronounced. In her colonies England can foster every quality of manly endurance and soldierly discipline. The native races, many of them warlike by nature and instinct, might also be trained in their turn for the safeguarding of the empire. The drafting of Sikhs to Africa and, say, Kaffirs to India, would-the first strangeness gone-tend to consolidate the British power and promote the fusion of the British dominions into one great and powerful whole. As a nursery for her seamen Britain's colonial empire is even of greater value. The vast mercantile navy which her enormous trade has called into being would furnish, in time of need, a sufficient supply of sailors slilled in their work and eager to emulate, in their country's behalf, the deeds of their fore-fellows, who earned for England the proud title of "the Mistress of the Seas."

The Future of the Colonies.-The great question of the future, as far as Imperial politics are concerned, is the relation which is to obtain between the mother country and her dependencies. As the colonies grow in wealth and influence the present position becomes more and more untenable, and the relations more and more strained. The question lies between two opinions. On the one hand it is claimed that each colony as soon as it becomes self-supporting; as soon, to speak figinatively, as it attuins its full growth, should be cut adrift from its parent and allowed to shift for itself as an independent nation, with no tie between it and the country that gare it birth, save only the sentiment arising from common race. On the other hand. it is insisted that the time has come 
for a closer union between Britain and her colonies; and tho followers of this belief advocate the formation of a great federation, which should unite all the colonies and dependencies of Great Britain under one vast dominion, the members of which, while enjoying the free exercise of all constitutional rights, and controlling all affairs pertaining to independent self-government, should yet render a loyal homage to the British Crown, and act, in questions affecting the welfare of the empire as a whole, in union with all the other units of that empire by means of some system of Imperial representation, by which each dependency could make its voice heard in the councils of the empirc. In support of the idea of federation stands the shining example of Canada. Since the formation of the Domiuion the progress of that Colony has been singularly rapid.* The Australian colonies followed Canada's example in 1900 , and although there has been some little difficulty with West Australia, owing to the general wealnness of the colony and her distance from the seat of government, the unification appears to be working well. A similar movement was long on foot for the federalisation of British South Africa, and by the Bill of 1909 the Rubicon has at length been crossed. The difficulties there are great-from race, language, religion, and geographical conditions. Still, the Mother Country will waft her benediction, and say-" Floreat !"

In the appointment of colonial lawyers to the Judicial Committee of the Privy Council (the Court which, sitting at Whitehall, hears colonial appeals), as well as in the despatch of colonial troops from Canada, Australia, New Zealand, etc., to the assistance of the mother country in the South African War of 1899-1902, some pioneer movements have been made towards Imperial Federation, which may perhaps be followed

- Some indication of the economic progress of Canada may be gleaned from the fact that in ten years-1 $999-1909$ - the increase in exported corn in one Canadian province alone was from $9,000,000$ to $200,000,000$ busbels. 
up in the near future. Disraeli's aphorism, that the unity of the British Empire "depends as much on sympathy as on foree," is certainly being more forcibly verified as time goes by, and "so is the still greater sentiment of Burke, when pleading for a more liberal and magnanimous treatment of Britain beyond the seas:-

"My hold of the colonies is in the close affeotion which "grows from common names, from kindred blood, from "similar privileges, and equal protection. These are ties, " which, though light as air, are as strong as links of iron. " Let the colonies always keep the idea of their civil rights " associated with your government-they will cling and "grapple to you; and no force under heaven will be of power "to tear them from their allegiance. But let it once be " understood, that your government may be one thing, and " their privileges another; that these two things may exist " without auy mutual relation, the cement is gone; the " cohesion is loosened; and everything bastens to decay and "dissolution. As long as you have the wisdom to keep the "sovereign authority of this country as the sanctuary of "liberty, the sacred temple consecrated to our common faith, " wherever the chosen race and sons of England worship free"dom, they will turn their faces towards you. The more " they multiply, the more friends you will have; the more " ardently they love liberty, the more perfect will be " their obedience. . . . This is the true Act of Navigation " which binds to you the commerce of the colonies, and "through them secures to you the wealth of the world. . . . "It is the spirit of the English constitution, which, infused "through the mighty mass, pervades, feeds, unites, " invigorates, vivifies every part of the empire, even down " to the minutest member. . . . We ought to elevate " our minds to the greatness of that trust to which the "order of Providence has called us. By adverting to the "dignity of this bigh calling, our ancestors have turned a 
INTRUDUC'YRY.

27

"silage wilderness into a glorious empire, and have made

"tho most extensive, and the only honourable conquest r,

"not by destroying, but by promoting the wealth, tho

"number, the happiness of the human race." 


\section{CHAPTER I.}

\section{- \\ Phases of the Empire's Growth.}

THE growth of the British Empire has been the work of three centuries of unremitting effort, in which our forefathers have borne the brunt of the hostility of the world.

Three great potentates of modern history have set themselves against it. Philip II. of Spain, Louis XIV. of France, and the first Napoleon, each endeavoured to stem its onward progress. Against them have been arrayed, on England's side, Elizabeth and her great seamen, William III. and the famous Duke of Marlborough, and Chatham and Nelson. Thus the history divides itself into three great historic duels, the first with Spain, and the second and third with France. The result of the first was the overthrow of the Spanish Empire, with its vast dominions across the Atlantic, and its claim under the Papal Bull to the monopoly of the New World. The second determined Spain's successor. Her European possessions passed to the House of Bourbon; her trude and her inaritime and colonial supremacy to England. The third shattered Napoleon's hopes, as British ascendency at sea crushed his projects of an empire in the east, and forced his anbition to confine itself to Europe.

Thus the ihree centuries which have elapsed between the death of Queen M vary in 1558 and the proclamation of Victoria's sovereiyuty over India in 1858 , fall naturally into three periods.

In the first of these, from the accession of Elizabeth to the death of Anne, England expanded into Great Britain and laid 
the foundations of her empire abroad. In the second, from the death of Anne to the battle of Waterloo, there was waged the long contest between Englind and France for supremacy in India and America, during which the British Empire rose from its foundations; while during the third period, from 1815 to 1858 , Britain admittedly supreme as a maritime and colonial power, bas everywhere extended, developed and consolidated the empire she had gained.

England and Spain.-It was against these adversaries and through these phases, that the small half islaud over which Elizabeth ruled, developed into the world wide empire which 'acknowledges Britain's sway. The efforts of the Elizabethan seamen, greatly as they shook the maritime supremacy of Spain, did little to affect her colonial empire. But Dralie was suoceeded by Raleigh, the pioneer of the Empire of the Seas, and by the founders of that vact Empire of the West, whose continents lay yet for the most part unexplored. Greater Britain sprang into existence when Englishmen made their permanent home across the Atlantic. In point of territory gained, the reign of Elizabeth has little to show. What it did was to initiate a policy of expansion and to strike at the foundations of the sea-power of Spain until the superstructure tottered to its fall. The natural consequence followed. The flag of England Hoated over every sea, and the trade of England followed the fiag.

"The Spanish Armada marks the moment when the period of pre. paration or apprenticeship closes. The nation ... looks no longer towards the oontinent, but towards the ocean and the New World. It bas become both maritime and industrial." - (SEELEY).

Holland ranged itself on the side of England in the contest and throughout the early Stuart period, Dutch and English are found combined as the rivals of Spain in commerce and in colonisation. 
England and Holland.-But the British Empire entered upon a new phase of its development with the establishment of the Commonwealth. Secure by land, it was essential that the Protectorate should guard itself against attack by sea. With the navy, which thus came into existence, organised by Vane and commanded by Blake, England finally committed herself to a maritime career.

"At this moment, England woke more clearly th"n ever before to a consciousness of her geographical position, of the fact that a maritime rocation was that to which she was called by nature itself."-(RANKE).

Trro events stand clearly prominent, the passing of the Navigation Act in 1651, and the seizure of Jamaica by Penn and Venables in 1655, "the most high-handed measure recorded tn the modern history of England."

Cromwell's foreign policy revealed England's great possi. bilities as a maritime power. "It is a first sketch of the British Empire."

"The Navigation Act consummated the work which had been commenced by Drake, discussed and expounded by Raleigh and continued by others. It completed the apparatus of our foreign trade by creating an English commercial navy."-(SEELEY).

But for England to commit herself to a maritime career was to enter into rivalry with the Dutch. The great power of Spain had sunk to a shadow. The revolt of Portugal had robbed her of much of her power and prestige.

France was wholly occupied with internal dissensions. Holland alone could offer a dangerous opposition, and henceforth, England and Holland were engaged in a deadly contest for supremacy. It was a war of growth and expansion for England, a struggle of life or death for Holland. The contest began with the massacre of Amboyna in 1623. It grew acute at the beginning of the reign of Charles II. It ended, when, in 1674. Charles II. withdrew from his alliance with France. From 
this time forward, England and Holland were once more side by side in resisting the aggressions of France. But the Dutch power had seen its meridian. Heneeforth it began to deeline.

"These sturdy seamen now lost the great position which they, like the Spaniards previously, had held for nearly a century, and the field was left clear for the rivalry of Great Britain and France by land and sea."-(Burrows).

England and France.-The next phase in the development of Greater Britain, found England and Holland once more allied, this time to resist the aggressions of France. The latter country had been little, if at all, behind England in exploration, and had even proceded her in settlement. When the pilgrims of the Mayflower founded, in 1620, the New England states, Acadia and Canada were already settled, and Champlain had founded, in the natural fortress of Quebec, the stronghold of French power in America. During the Protectorate, French policy had lain in the hands of Cardinal Mazarin to whom colonial development did not appeal. France fell behind in the race for expansion. He died in the year after the Restoriation, and was succeeded by Colbert. The latter, full of the spirit of the times, entered into eager competition with English and Dutch for the empire of the New World, and the commerce of the Old. Hence the efforts of France to set England and Holland at variance and to keep them so. The restoration of peace, or the supremacy of either combatant, would have left her face to face with a formidable adversary. The combatants, finding that the policy of France was to allow thein to destroy one another, speedily made peace and took sides against their common adversary, and the Netherlands and Britain were driven into a close alliance which mutual interest preserved intact for more than a century. It was eemented by the accession of the Dutch Stadholder, William of Orange, to the English throne, and was indeed, one of the main causes of the English revolution of 1688 . 
Two of the most characteristic features of the early part of the struggle were the series of naval victories gained by England over the French, commencing with that of La Hogue, and the eren more brilliant series of battles on land which are associated with the genius of Marlborough. But it was abroad, among the colonies of India and America, that the contest was keenest. France and Spain closed round our American settlements, and together attempted to shut our commerce from the Mediterranean. In India, the French were already dreaming of a great empire of the East built upon the ruins of British dominion. In the struggle which ensued, Britain, after many vicissitudes, was everywhere successful. In the Mediterranean, the capture of Gibraltar secured the British commerce with the East, while shutting off the western ports of France and Spain from communication with those upon the Mediterranean. In America, Pitt's scheme for the conquest of Canada was carried to a perfect realisation, and the fall of Quebec in $\mathbf{1 7 5 9}$ added French North America to the British Empire. In India, the military genius of Clire, and the administrative ability of Warren Hastings, placed the British power upon a basis too firm to be easily shalien. The accession of Napoleon renewed the conflict. His design was to regain for France in the Mediterranean, in India and in the New World, the supremacy of which she had been deprived. His failure to do so was the great failure of his life. Vanquished at the Nile, driven from Egypt and then from Malta, his naval power annihilated at Trafalgar, he had to fall back on an attempt to break the British power by ruining British trade. His fall at Waterloo set the coping stone in the security of the British Empire, and in securing it, gained for her, as the reward of three centuries of strenuous effort and desperate struggle against heavy odds, a world-wide commerce and an empire on which the sun never sets. 


\section{CHAPTER II.}

\section{- \\ The Early Navigators.}

Tne year 1558 marks a erisis in the history of England. If was the year in whieh Queen Elizabeth came to the throne and the great rivalry between England and Spain began. From this time dates that great impulse of diseovery and exploration which was to plant England's flag in every quarter of the globe: from the defeat of the Armula, thirty years later, we may reckon the commeneement of her supremacy upon the sea, which alone enabled the work to be sueeessfully aceomplished. True, navigators had sailed from England on voyages of diseovery before that date, and inrestigators had previously explored new regions, but such attempts were rather the result of isolated efforts than due to any great national movement for the extension of the empire or of its commeree.

The Bristol Merchants. - Foremost in the annals of English commeree stand the merchants of Bristol. First on the list of English explorers is to be found their ehosen navigator, Sebastian Cabot. Towards the end of the fifteenth eentury there settled in Bristol one Gioranni Cabotto (or Gabotto), a man slilled in the geographical lore of his day, and, withad, a man of enterprise and daring. He, in the year 1496, first beeame emulous of rivalling, in the interests of the country of his adoption, the exploits of Columbus. "of whom there was great talk in the court of King Henry VII., insomuch that all men, with great aduiration, altimed it to be a thing * more divine than human to sail by the west into the east by a way that was never linown before." From Henry VII., Sebastian sought permission to attenupt a like voyage of discovery. That monarch, keen to the advantages of the projeet, if chary to adventure on his own part, freely grauted a 
patent to "John Cabote, citizen of Venice; to Lewes, Sebastian and Santius, sons of the said John, settled at Bristol, to navigate the northern seas under the English flag with five ships and as many men as they should think proper at their own sole cost and charges, to discover the Countries of Gentiles or Infidels, in whatever part of the world situated, which had hitherto been unknown to all Christians," and, further, to rule such countries, "as our vassals, lieutenants, governors or deputies-the dominions, title and jurisdiction of them remaining with us, and a fifth part of the profits of such enterprise being payable to us; "-a most economical arrangement on the part of the King, and one thoroughly characteristic of the gracious monarch from whom it proceeded.

With two ships, Cabot sailed from the port of Bristol, toward the end of May, 1497, on perhaps the most momentous voyage in English history, for with it begins the history of English colonisation. Sailing to the north and west, he touched at Iceland, and thence, impressed by the legends of the early Vilings, determined to follow their path and win, if it might be, to the fertile land they had discovered beyond the western ocean.

It is to the Vikings, our brothers in blood, rather than to Genoese or Spaniard, that the credit of the discovery of America is due. The history of their royaging is preserved in the old Norse sagas of Eric the Red, and of Thorfinn Earlsefni, botb dating, in their mannscript shape, from the twelfth century and probably handed down from skald to skald, for some generations before that. Here, with mach that is mythical and more that is conjectural, there is mingled sulficient truth to enable modern geographers to trace the course of their royages with something approaching to certainty, and to connect the Hellaland, Murkland and Vinland of the Scandinavian sagas, with Newfoundland, Nova Scoti?, and the New England provinces of the present day, while the wonderful Furthastrandir is, with little margin of doubt, the name they applied to the sandy besches of Chatham and Monomy, lying to the south of Cape Cod.

Following in their track, Cabot reached land. True, it was not the Cathay which he sought. No one could have mistaken 


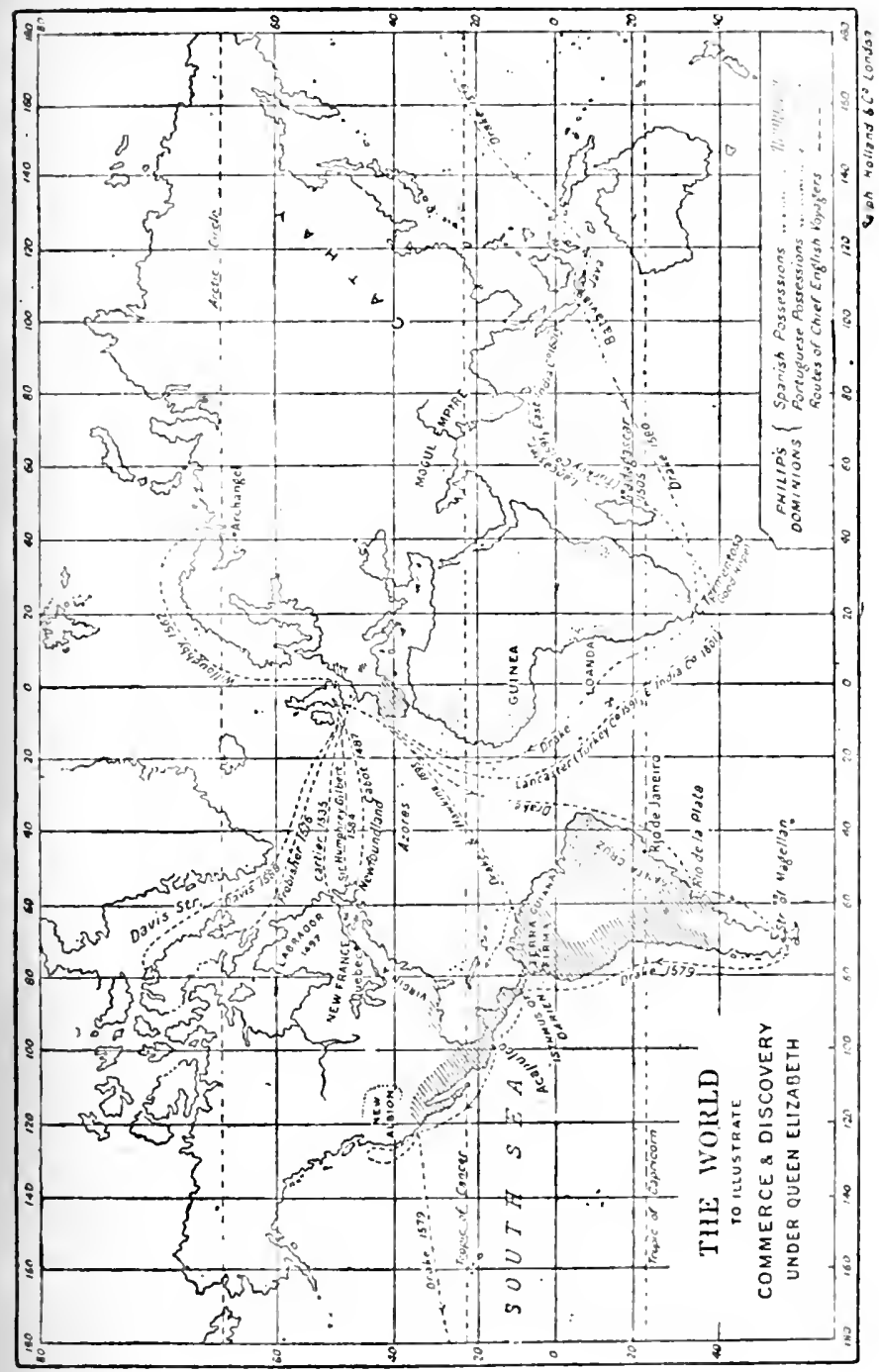


its rocky and icebound coast for the golden sands of that fabled region, or its barren soil for the luxuriant vegetation of the tropics. So his crew concluded, and as each day the number of icebergs increased and the sea fogs grew denser and denser, they insisted upon his quitting this inhospitable region, where there was nothing save a wonderful and apparently inexhaustible supply of fish. He was in Bristol again in August, and his report led to the formation of a fleet, which, year by year, set out from that port to gather the harvest of the sea upon the rich banks of Cabot's "New-found. land." Fishing stations were established where the "take" might be cured, and to maintain these, certain of the seamen, the first English settlers in America, made their home on the shores of Labrador, carrying on, between the fishing seasons, a rude traffic with the natives and collecting what rarities the country afforded for sale at home.

Henry VII., in 1505, paid 13s. 4d. "for popinjass, and wild cats of the Newfoundland islands." At the period when our history begins, the Newfoundland fishery had risen into considerable importance, some forty ships were engaged in it and the prosperity of the fishing towns of the west of England greatly increased. Although Cabot's search for Cathay had been vain, the spirit of discovery was in no wise quenched. Other expeditions were planned, and the royal aid sought. Still no substantial result followed. The adventurers were nnable, alone, to subsidise the enterprise, while the parsimonious king was so chary of his wealth, that he not only refused them assistance, but even when a continent was discovered for him, would not be at the expense of developing its resources. It is, however, only jnst to note that the record of Henry's Privy Purse contains under date, August 10,1197, the entry: " $£ 10$ to him that found the new isle."

Sebastian Cabot. Numbers of royages were, however, made at the cost of private persons, and many of these owed their origin to the zeal of Sebastian Cabot. He had, in his youth, procceded to Spain, where Charles V. made him the Pilot-21ajor of the Empire. In 1547, after a disastrous royage to La Plata, he came to England, and had much to do with the planning of the royages of Willoughby and Stephen Borrough, in seareh of the North-East passage to Cathay, a quest he bad himself madcraken in 1517 . Ten years later, be died in 
great ohscurity, and in the direst poverty, but his fawe has grown tiil he is now recognised as having been one of the freatest of navigator. and cosmographers, "the autbor of the maritime strength of Englanil, who opened the way to those improvenents which bave made thu English so great, so eminent and so tlourishing a people."

Throughout the whole of Elizabeth's reign the desire of exploration grew, fed by the tales spread by English seamen of the wealth of the Spanish settlements beyond the Atlantie.

Two famous half-brothers, Sir Humphry

sir Humphry Gilbert and Sir Walter Raleigh, led the van. The former had arranged at his own expense, two voyages to the western seas, only to find his projects of colonisation thwarted by the inefficiency and half-heartedness of his crews. In June, 1583, undaunted by his former failures, he succeeded in fitting out five ships in order to plant a colony on the shores of Newfoundland. From this royage he never returned. His men, lacking his zeal, refused to proceed with the hazardous task he had set himself of mapping the dangerous coast for the benefit of future voyagers and compelled him to turn homewards. Twothirds of the way had been passed when there fell foul weather and "seas breaking short and pyramid-wise." The remainder may be given in the words of the original chronicler. "Monday, the 9th of September, the frigate was near cast " away, oppressed by the waves, but at that time recovered, "and giving forth signs of joy, the general sitting abaft with " $a$ book in his hand, eried unto us in the Hinde, so often as "we did approach within hearing, "We are as near to "Ieaven by sea as by land,' reiterating the same speech, " bescentning a soldier resolute in Jesus Christ as I can "testify he was. The same Monday night, about twelve of "the clock, the frigate being ahead of us in the 'Golden " Hinde,' suddenly her lights were out, whereof, as it were "in a moment, we lost the sight; and withal, our watch " cried 'The General was cast away,' which was too truo."(HakLUXT'S VOTaGrs.! 
It is interesting to note the size of the ships of his little fieet. The "Delight" was 120 tons, the "Raleigh" 200 tons (she, howerer, deserted off the Land's End, the "Golden Hinde " and the "Swallow," both of 40 tons, while the "Squirrel," which the chronicler culls "the frigate"-the ressel chosen by Sir Humphry for all his investigations, and the one in which he rrent down, was bnt of 10 tons burden.

Nor was Raleigh more successful. In 1584 he obtained a charter from her Majesty appointing him successor to Sir Humphry Gilbert. The following year he organised an expedition to Virginin, founding there a colony which led a precarious existence for a twelvemonth, at the end of which time the colonists, by their harsh treatment of the Indians, provoked so severe a retaliation that they were glad to return again to England. A second body of colonists, planted in 1587 , was killed to a man, the result of the legacy of hate its predecessors had won.

Still, these were but the first ripples of that great tide which was to follow. The business of Englishmen, under good Queen Bess, was not so much to colonise as to fight, and, in fighting, to win for their country the mastery of the sea, to defeat the Spaniard, and to prepare the way for the expansion which was to come.

The Sea-Dogs.-Elizabeth's policy in the early part of her reign had been to keep the peace, above all with Spain. Her people were of another mind. The growing enthusiasm for discovery sent one adventurous Englishman after another across the Atlantic, to poach upon the preserves of Spain. Many were the deeds of daring they performed, till the terror of their names spread through the Spanish ports. Ever at home upon the sea, the English seamen now learned to ply their craft with unmatched skill, to fight against their great rival, no matter how heavy the odds, and, in most cases, to win. The Spaniards hated them no less than they fcared them, and when, as often occurred, a few wretched Englishmen fell into their hands, the tortures of the Inquisition were requisi. 


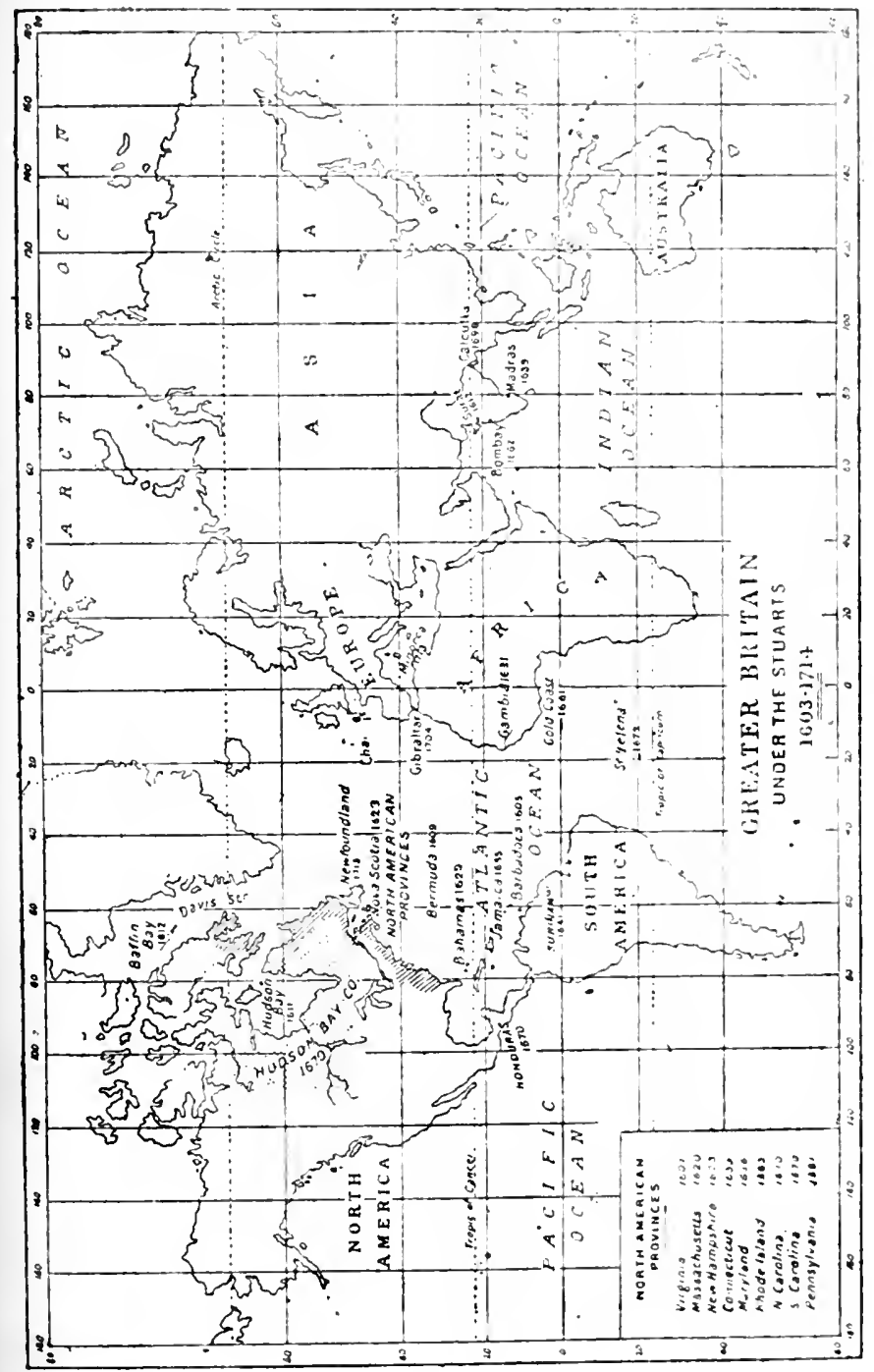


tioned to wipe out the debt of revenge which the daring of his companions had incurred, and many an English prisoner, escaping from the Spanish dungeons, carried home tales of horrors which made the blood boil with desire for retaliation. Moreover, there werc immense riches to be won on the Spanish main. The Spaniards at home, too, by reason of their religion and the attempts they had made-and were still prepared to malie-to force it upon England, furnished another cause for revenge. Thus such men as Drake, Hawkins, Howard, Paleigh and Grenville were actuated by motives which were curiously diverse. Peligion, discovery, revenge and gold were with them impulses of almost equal weight. Their hearts were stirred by the tales of the cruelties of the Inquisition, and their imaginations fired by the stories of the wonders and the wealth of the Americas. While the profits to be gained by a farourable royage were such as to justify the risk and compensate, in some degree, for the perils of the vorage, it was the same chivalrous spirit as sent all Europe, at the bidding of Peter the Hermit, against the Infidel, that actuated these rovers of the sea. They believed themselves the champions of Protestantism against the Spaniard and that to damage his powcr, to capture his galleons, to free his slaves, and, above all, to destroy his influence and break the power of the Inquisition was a task meet for God's elect, and it was in this spirit that they met the Spaniard with a fanaticism is great as his own. It has been the fashion during these lattci years to term such adventurers pirates, and to see in such a man as Drake or Raleigh nothing more than a successful bnccaneer, one whose animal courage was beyond question, but whose pretences to religion were almost on a par with the derotion of an African savage to his fetish.

As an illustration of the feeling with which they set about their task, the following quotations may suffice. The first is from a letter of Raleigh's, who had gained the consent of 
the statesmen of his day to an attempt to colonise Guiann. The attempt was never made, for the Spinish Armada called for the services of all such as he at home.

"Who will not be persuaded that now at length the great "judge of the world hath heard the sigh;, groans and "lamentations, hath seen the tears and blood of so many " millions of innoeent men, women and children, anlicted, " robbed, reviled, branded with hot irous, roasted, dis" membered, mangled, stabbed, whipped, raeked, scalded " with hot oil, put to the strappado, ripped alive, behended " in sport, drowned, dashed against the roeks, famisbed, " devoured by mastiffs, burned and by infinite tortures "consumed, and purposeth to sconrge and plague that "cursed nation, and to take the yoke of servitude from that "distressed people, as free by nature as any Christian."

When one remembers that in addition to the list of tortures given above, English prisoners were subject to the terrors of the Inquisition, and that the said prisoners incluted townsmen, friends and brothers of the "Sea-dogs" of Elizabeth's time, one begins to understand somewhat of the hatred of Spain whieh filled their hearts and led them to those reprisals which ended in the destruetion of the naval and colonial supremaey of Spain and the development of the British empire. The noble words whieh follow are the coneluding sentences of a memorial, drawn up by Sir Humphry Gilbert after his examination by her Majesty's Privy Couneil, as to the results of his voyages.

"Never therefore mislike with me for taking in hand any "landable and honest enterprise, for if through pleasure or "idleness we purchase shame, the pleasure vanisheth, but " the shamo abideth for ever.

"Give me leave therefore, without offence, always to live and "die in this mind: that he is not worthy to live at all, that, " for fear or danger of death shunneth his country's servico 
" and his own hollour, seeing that death is inevitable and the "fame of virtue immortal, wherefore, in this behalf, mutare "vel timerc sperno."

No one can read such great words as these and not feel thia the spirit which actuated these seamen of old was far different from the vulgin greed of gain or the bloody lust of slaughter. No one who reads and can appreciate such high thoughts as tinese, can associate the noble spirit and ligh aspirations which shine through them with the name of pirate. Even Hawlins, first of English slave dealers though he was, showed himself actuated by the like spirit. Among the regulations of his voyage was one to the eflect that the crew should gather together "morning and evening to serve God," while a fre that occurred on one of his ships was made the occasion to banish profane swearing, a notable achievement in the days of Elizabeth, when everyone's mouth, from her Majesty's downward, was full of strange oaths. Altogether, the picture left us by the Sea-dogs of the Elizabethan age is one of gallantry, disinterestedness and high heroic energy, all the more remark. able since it was the result of no special discipline or training but a spontaneous growth among the men themselves.

The North-West Passage.-The same spirit was shown in the many expeditions to the Arctic seas. Hither the attention of the navigators was early drawn in the hope of finding a north-west passage to India. "The ice was strong but God was stronger," says one of Frobisher's men, after griuding for a day and a night among the icebergs, not waiting for God to come down and split the ice for him but toiling manfully through the long hours, and then, when all had been done that man could do, rendering the glory to the Creator.

The attempts to discover a North-East or North-West Passage furnish some of the finest episodes of that stirring time. The first among our countrymen to seek to traverse the 
Ice-bound highway was Willoughby, who with two ships started in the year 1553. Of the vicissitudes of the voyage. we know nothing. Of its fate we unhappily know more. Two year: later some Russian fishermen found in the haven of Arzina, in Lapland, two ships fast frozen in the ice and round about thez: Willoughby and his companions-serenty cicad men. The ships were freighted with their frozen erews and set sail for England, but being, as is surmised, unstauneh by reason of their two winters' sojourn among the ice, sank by the was with their dead and those who navigated thom. Thire followed Martin Frobisher, with two ships the Gabriel and the Michacl and a pinnace, on June 9th, 1576. His second royizge took place in the next year and his third, with a lleet of fifteen ships, in the next.

His suceessor was John Davis, a man of remuriable daring, skill as a navigator, and peculiar sweetness of character and disposition; a man whose epitaph is written on the map of the world, in enduring testimony to the suecess of his royages. He was the first to reach the great ice-barrier, which he coasted for thirteen days without finding an opening. Then his crew began to murmur and to fall siek and beeome faint-hearted, as well they might, for ropes and shrouds were siff with ice, ant there was none of the elaborate precautions against cold and hunger that are to be met with in modern voyages of explorittion to the frozen seas. But the remainder of the story shali be given in his own words.

"Our men through this extremity began to grow sick and "fecble and withal hopeless of good success; wherenpon, "very orderly, with good discretion they cutreated me to " regard the state of this business and withal advised me " that in conscience I ought to regard the saiety of mine own "life with the preservation of theirs, and that I should not "through orerboldness, leave their widows and fatheriess " children to give me bitter curses . . . Whereupon 
"secking help from God, the fountain of all mercies, it " pleased His Divine Majesty to move my heart to prosecuto " that which I hope shall be to His glory and to the conten" tation of every Christian mind."-(HakLUYT'S VoYAGES.)

The determination thus arrived at was to make over his large vessel, the Mermaid, of 120 tons, to such as wished to return, while he with a volunteer crew prosecuted the voyage in the Moonlight, a craft of 35 tons, "thinking it better to die with honour than to live with infany." The upshot of the decision, so adventurously taken, was the discovery of that great arm of the sea ever since known as Davis Strait. He reached four degrees north of the highest point yet attained, coasted along the shores of America and discovered Hudson Strait, which was then and for many a year after believed to be the longed-for passage to the Indies.

The Buccaneers. - The great adventurers of the days of Elizabeth were succeeded by a race not less adventurous, hardy and daring, but who were actuated rather by a greed of gain than by any of those heroic aspirations which had stimulated their forerunners. Early in the seventeenth century, as soon as it was shown that the Spanish power was no longer supreme upon the sea, there flocked to the West Indies crowds of haray seamen, English, French and Dutch, all burning with the desire to prey upon Spanish commerce and upon the Spanish colonies. These were the buccaneers. The English and French were mainly pirates, the Dutch confined their attention chielly to the less daring but equally lucrative trade of smuggling. The business was a profitable one and the seas round the Spanish main swarmed with thousands of swift and well-equipped ships, vliebooten as the Dutch called them, a name corrupted by men of other speech into freebooters or filibusters.

The term buccaneer is derived from the Caribbean word boucan, a place or hut for smoling meat, and was given in the 
first place to those Europeans who had settled in the West Indies for the purpose of hunting the wild animals to be found there and of swoking their flesh to preserve it for exportation. The immense profits of piracy caused the abandonment of these more peaceful pursuits, the number of the buceineers increased, and they banded together under a rough code of laws as the "brethren of the coast," annong whom all provision for sustenance was in common and whose fellowship supplied the place of those domestic ties from which their lawless deeds had cut them off for ever. The chief virtue of the community was physical courage, wich, urged by desperation, frequently reached a marvellous pitch. But that same fear of the gallows, which prompted many of their most daring exploits, frequently converted the bold adventurer into a reckless savage, and the terrible deeds of buccaneers became a byword throughout Europe and finally led to expeditions for their extermination.

As often as not, indeed, the privateers who were licensed against them ended by joining them, until the buceaneers became strong enough, had they been efliciently led, to have conquered all the Americas. As it was, they made themselves a name of terror along the shores of New Spain, passed into the Pacific, and swept its coasts as far as California. Van Horn and Morgan, Grammont, Lolonois and Dampier were names of fear in the Spauish main. When Spain abandoned her clain to the exclusive possession of the West Indies, many of them were induced, by the promise of grants of land, to settle down and abandon piracy for planting. For a long time the little island of Tortuga had been their chief place of resort. Here they had established a coluny where they spent their gains in wild excess, and where also erowied those traders who lived by ministering to their vices. A terriblc attack by Spain; while its fighting population was at sea, laid waste thg island and destroyed its rude civilisation. Then France seized 
it, permitted none but French buccaneers to resort thither, and Tortuga became a French colony. The English rovers, seeking another haunt, found one ready to hand in Jamaica, which had only just been captured by Cromwell's forces, under Penn and Venables. Thither a vast number of the buccaneers repaired, and lent powerful aid in repulsing Spanish attempts to recover the island in 1657 and 1658 . Because of this assistance, the English governor countenanced them. The island became their headquarters; its wealth was vastly increased by their extravagances, and its morals were vitiated by their debauchery.

"Port Royal, itself, united to more than regal opuleuce the worst vices and the lowest depravity that ever disgraced a seaport; nor could anything else be expected in a city whose most honoured denizens were buccaneers, whose most wclcome visitors were slave traders."-MARTIN.

Henry fiorgan.-First and most formidable on the roll of the buccaneers was the name of Henry Morgan. At the height of his fame, the terror of his name was such that women used it to awe fractious children to sleep, while themselres lying awake in quakins terror. His roving disposition early appeared, when, in his youth, rather than settle to the humdrum routine of a comntry village, he took ship for the Barbadoes, paying for his passage thither by allowing himself at the journey's end, to be sold, for a term, into the "white slavery" of the plantations. The period of service expired, he was attracted by the lawless life of the buccaneers, then beginning to rise into notoriety. Here he found fitting scope for his talents. He speedily showed himself more lawless, brutal and debauched than the worst of his companions, while his daring and genius as a commander speedily won him pre-eminence among the crew. He was a born leader of men, and his ambition was equal to his talents. Un $I \in r$ his rule, the buccaneers were oryanised in to something like discipline, and he determined to attempt, with their aid, the great enterprise on which be had set his mind, nothing less than the conquest of the whole of the Spanish Americas; an undertaking from which he hoped to win great plunder for himself and perhaps new dominion for his conntry.

His first attempt was on Portobello, which he carried by assault. Hero his regources and unscrupulousness were displayed in his infamous but effective device for enabling his followers to scale the walls in safety. Before delivering the assault, he had captured certain neighbouring religious houses, and the monks and nuns from these were now forced up 
the sealing ladders in the front of the stormers, Morgan salculating that tue reverence inspired by their calling would prevent the defenders from flring upon them, and that their presence would thus secure his troops from loss. The city was captured, looted and left a very wilderness of desolation. The fame of the exploit brought rerruits to his flag till be found himself at the hend of an army, small it is true, but terrible in its strength, since each mun fought with the fear of death behind him. Panama was the next aim, and towards this stronghold of the spaniob power in America, the buc'aneers now marched. Ten days' toilsome journey lay between them and their goal. Provisions were scarce, the difticulties of the route immense, but the buccaneers presned forward. The dawn was rising on its glittering roofs when they sishted the city, and moved by sudden impulse, the great band of organised ferocity threw itself, as one man, on its linees, "rendering thanks to God for so anspicious a termination to the voyage."

Success at tented them here as at Portobello, and after the nsual interval of debauchery and license, the adrenturers returned with a hundrel and serenty mules hien with their phnder-gold, silver and jewels. Signs were not, howcrer, wanting that Mor gan's success hall aroused the jealousy of his companions; and juts for bis deposition were speedily on foot. Morgan wisely determined not to await their derelop.; ent and, with the greater part of the spoil in his Lossession, set s:il for Eugland, anding to the greatness of his notnriety, the distirction of being the only buccaneer of any standing who had robbed his comrndes. In Eagland bis good qualities, or perinps, the wealth he bad acquired, earned him the favour of King Charles II. by whom he was suecessively made Commander in the Royal Navy, Knight, ant Governor of Jamaica, in which last office, says an old bistorian: "Sir Henry much distinguished himsell by the rigilance and severity with which he suppressed those unlawful bolies of pirates called buccaneers." Thus after Morgan's defection, buccaneering hegan to wane. He hanged so many of his old comrades thut the work grew scanty and unremunerative. The rud flag still floted here and there in the Spanish main, and now and again was seen at the head of a successial foray on the coast, but at Morgan's death the buccaneers, their haunts ravaged and their ships burned, had practically becone extinct as a class. The romance which had surrounded their calling was gone. They became mere vulgar pirates, and as such, every man's hand was against them. With the death of the notorious Captain Kidd at "Lxecution Dock," thirty years later, the name of buccancer ceased to be a name of terror among the shipping and in the seaports of the Western main.

The Plantations.- The earliest Spanish settlements had been made upon the Islands of the West Indies. The whole of 
the West Indian group, settled and unsettled, was included in the dominions which the Spaniards claimed, and to which they gave the title of New Spain. But the wealth there sought by the Spaniards was that which could be obtained with little expenditure of labour-their booty was the gold and silver that lay almost exposed upon the soil or which had been laboriously acquired by the inhabitants, and which was now ravished from them by the conquering and rapacious Spaniards. The store of wealth was small, new and richer discoveries tempted them to Peru and Mexico, and the beautiful islands, once drained of their portable riches, were almost totally neglected. No account was made of the wonderful fertility of the soil, in time to come to prove a source of riches greater even than the gold and silver mines of the main. land. When Spain, through pressure elsewhere, tacitly relinquished her claims, there were not wanting men of other nationalities-English, French and Dutch, capable of discerning the potentialities of these islands. Vast planta. tions of sugar, cocoa, indigo and cotton sprang up. The fame of the plantations spread; the riches of the planters were magnified and other islands hitherto unoccupied by Europeans, became in their turn great centres of human industry, and of immigration from the home country. But the great difficulty the planters had to face was the scarcity of labour. The cruelty of the Spaniards had alienated the native races; indeed, in too many cases, had all but exterminated them, and what might have been flourishing plantations now languished for want of labour. Cromwell, when Jamaica had fallen into his hands, solved the difficulty, characteristically, by ordering the Scotch government to collect all the idle and disaffected persons they could find, and to ship them off to Jamaica. Many others were procured from Ireland, where, after the terrible settlement of the country by Heury Cromwell, there must have been many to whom this compulsory exile 
was a positive benefit. Following this example, it became customary to despatch prisoners, on conriction, to the plantations, where they were sold into slavery for a term of years, and grants of such prisoners were frequently made to persons who had influence with the government, or some clain upon it which, it was desirable, should be satisfied. Prisoners taken in battle or persons found, in a time of disaffec. tion, with arms in their hands, were often subjected to similar treatment. Thus, after Sedgemoor, eonsiderible numbers of those tried by the infamous. Teffrer's were thus despatched, being granted by the Crown, in the first place, to various persons and sold by these to merchants; who, in turn, calculated to make a profit by disposing of their white slaves to the Alueriem planters. (A similar plan was tried in the case of the Australian colonies. The secession of the United States had put an end to the transportation of convicts to the plantations of America, and the discoveries of Captain Cook came at the exact moment when the nation was most exercised as to the disposal of its convicted prisoners.) But the supply of white labour was by no means sufficient to meet the demand. Hence arose the dependence of America on Africa for labour. Spaniaris and Portinguese sought labourers for the work in their mines, the planters found them no less essential upon their vast farms of sugar, tobacco, indigo, cotton or rice.

The Slave Trade.-The difliculty was met by the introrlue. tion of negro slaves. An Englishman, Sir John Harlins, is notorious as being the first European slave tracier to the Amcricas. Slaves had, however, been bought and sold from time inmemorial in the markets of the enst. They were now introduced into those of the west. The Portuguese were the first to develop the trade to anything like consicierable pro. portions. Their colonies on the African coast, furnishel an inexhaustible supply of negroes, and their plantations in $13 \mathrm{rnzi}]$ were the first to take advantage of it. Later, when the decline 
of the Portuguese empire in the east placed their carrying trade in the hands of the English, the slave trade went with it, and England became the great slave trading nation of the world.

The introduction of negroes into the West India plantations once effected, they speedily became indispensable, and every planter set apart a share of his capital for the purchase of slaves, and a portion of his yearly profits for the maintenance of his stock; for the effect of the arduous labour and the terrible conditions under which it was carried on, was such, that the slave mortality became extreme, averaging, over a considerable number of years, no less than 16 per cent. of the total negro population.

It is a matter of regret that the slaves in the English plantations were legally worse off than in those of any other nation. There the slaves were entirely at the mercy of their owner; in the French colonies they had certain civil rights secured to them by the Code Noir, passed in 1685, while the Spanish planters showed themselves more humane than the original conquerors of the country, or the Spanish gold-seekers who followed them. It is possible that without slave labour. it would have been impossible to cultivate the West Indies, to anything like the same extent, since the climate forbids anything like sustained labour to the natives of temperate climates on peril of their lives. This of course argues nothing in favour of the nefarious traffic in slaves. Under the conditions which obtain at present, free labour is not only more desirable than slave labour from the point of view of morality, but also from that of economy. The researches of political economists have shom that no form of labour is so dear as slave labour, and that only the most remunerative crops are capable of sustaining the heavy expenditure it entails, and that wherever it has been elticiently replaced by free labour, the rate of production has increased and the prosperity, both of the community and of the individual planter has been stimulated by the change. 


\section{CHAPTER III.}

\section{$-\mathrm{O}-$ \\ British Rule in India.}

\section{SECTION I.-BEFORE 1858.}

TuE history of British rule in India may be fairly said to have commenced with the last day of the sixteenth ecntury, when Queen Elizabeth of glorious memory, keenly desirous for the glory of England and no less liecnly alive to her own interests, granted a charter to "The Governors and Company of the Merchants of the City of London trading to the East Indies," empowering them to carry on trade, acquire territory by treaty or conquest, and raise troops for the defence of their possessions.

The riches of the Indies were, however, by no means unknown. Drake and Cavendish had called there on their return "by way of the Portugals," from their adventurous royages, and English merchants had carried on a successful, if limited, trade by the overland route. Moreover, the daring of English seamen had wrested from the Portugnese, then the masters of the trade to the East, the spoils of war in the shape of many a richly laden galleon. But in the year 1580, the union of the crowns of Spain and Portugal converted the latter into little more than a province of her more powerful neighbour, and from this time her power upon the sea began to decline,-Spain, the predouninant partner. concentrating all her strength upon the development of her Anericun dominions. As a result, the Duteh gradually acquirel the commercial supremacy of the East and the magnificent Portuguese 
possessions dwindled sadly by degrees, till they came to consist of only a few small separate stations, of which Goa and Diu were the chief.

The Company in India.-The first voyage of the new company was undertaken under the command of the veteran Lancaster, in 1601. This, however, together with the next two, were to the Spice Islands and not to the mainland of India, a fact which brought the English traders into direct and open rivalry with the Dutch.

In 1609, however, Captain Harrkins landed at Surat on a mission, unfortunately unsuccessful, to the Shah Jchan, praying him to grant facilities for trade. Captain Best, in 1612, was more fortunate and readily obtained from the Mogul permission to establish an English factory at Surat.

The factory was built in the same year, and with it the foundation of the British Empire in India was laid. The three years which followed were years of steady derelopment, and at their close the intercourse between Englind and Hindustan, hitherto spasmodic, had grown into a regulat', if somewhat attenuated, stream of commerce. In 1615, the first English ambassador reached the court of the Great Mogul in the person of Sir Thornas Roe, to whose tact and diplomatic powers the Company were indebted for the favour shown them by that potentate, for the concession of the right to plant factories ancrihere in his dominions, for their security from rexetious exactions and for varions facilities in the transport of their merchindise to and from their settlements.

The English and Dutch.-Meanwhile the progress of the trade with the Spice Islands had aroused the apprehensions of the Dutch, and the traders were speedily in open rivalry. True, efforts were made by the home goveruments to patch up a compromise, and in 1619 a treaty of peace was signed. By this the English company was to clain as its right 
one-third of the spices from the Dutch islands and one-ha!t of the pepper from Java, while the forces of both nations were to unite to hasten the decline of Portugal. The news of the treaty brought a momentary cessation of hostilities. The fleets exchanged the battle cannonade for harniless salvos of polite congratulation. But the peace was as transient as the smoke of that salutation, the rivalry ripened into jeilousy

The Massacre of Amboyna, 1623. and jealousy broke into open warfare. The cliwax came with the notorious massacre at Amboyna. The Dutch, professing to fear their English rivals, suborned certain of their Japanese servants to swear to the existence of a plot among the British for the capture of the fort and the subsequent expulsion of the Dutch. It was pitcnt that there was little to fear, since the Dutch were vastly more powerful than their rivals. The former, however, glad of any pretext, seized the most prominent of the English, put them to the torture, and, extorting from them in their agony a confession of the truth of the accusation, made this the ground for a secret attack upon the remainder of the English traders. The massacre which followed caused England to thrill with indignation, but the country was too deeply involved in her quarrel with Spain to lightly enter upon war with Spain's greatest enemy. The Dutch government promised retribution but took no very decided steps towards discovering those of its subjects implicated, although the question furnished sulticient matter for negotiations extending over some two years. The upshot of the whole matter was that the English trade with the Spice Islands was ruined. The Dutch, in reprisal for the alleged treachery, made themsclves masters of the English factorics in the islands, thus monopolising the trade as at first.

The effect of this check was in the end beneficial to England. All her energies were now directed to the mainland of India, where she began to make rapid headway. Ilere the 
Dutch, though equally hostile, had not the same power of offence, for the East India Company had since 1615 grown with such rapid strides as to make it a power to be reckoned with.

Its career was, however, by no means unchequered. Its adversaries were many. These included the trading companies of other nations and "pirate" companies of its own, for the possession of so profitable a monopoly was by no means grateful to other traders, who cast a covetous eye on the riches of the East. The native rulers, too, saw its encroachments with growing apprehension, while the depredations of pirates and (in war-time) privateers, upon its fleet made considerable inroads upon its profits. Moreover, its growing wealth made it the prey of impecunious monarchs, whose coffers needed replenishing and who were quick to seize upon the renewal of its charter as a convenient occasion for mulcting it in heavy and ever-increasing sums.

The Pepper Loan.-Charles I., in 1640, seized the pepper warehoused by the Company, and valued, wholesale, at 2s. 1d. per lb. and sold it at 1s. 8 d. He obtained $£ 50,626$ in casb ; the traders were paid in bills, which were unmet for many years.

In 1624, Morris Abbott, brother of the Archbishop of Canterbury, became Governor of the Company, and under his able administration its affairs steadily prospered. The year 1630 saw the final defeat of the Portuguese, and England had now to reckon only with the Dutch. The great danger was lest the weak, though thriving, settlements should be invaded from the great Dutch colony of Java, and it was to guard against the possibility of this that the factory of Armegon, on the Coromandel coast, was strongly fortified, and the factories in what was after the Madras Presidency protected by the erection of Fort St. George in 1639. The extent of the British power in India at this period may be gathered from the fact that the defence was entrusted to two imposing garrisons of 
twenoy-liree and twenty-six respectively. Bombay, part of the dower of Catherine of limganza, was leased by ('harles II. to the Company in 1608, and in 1655 replaced Surat as its headquarters on the Malabar coast. In 169\%, the Bengit] Presidency, with Fort William-afterwards Calcutta-as its centre, was founded.

At the time of the foundation of the fnetory of Madras, the affuirs of the Company had grown to such an extent that the dockyrud at Doptford was not large enough to provide sufficient accommodation, ind a piece of ground was purchasel in a marsh at Blackwall and a new dock built. The Company now built its own ships, made its own sails and cordage, bakel its own brend and mate its own gunpowder, and, generally, didererything that was necded in the titting out of its vessels. It was not, however, able to build fast enough for its needs, and was compelled to hire ships to make un its fleets.

John Company. - Chief among the foes of the company were those merchants who advocited the policy of free-trade to the Indies and consequently deprecated the existence of the company.

These steadily opposed its monopoly, and with such success, that Cromwell was all but indueed to suppress it. The danger, however, blew over for the time, but reached a crisis in the reign of William III. when the free-traders succeeded in obtaining a charter of incorporation as the "General Company of Merehants of England Trading to the East Inclies," and commenced a competition which threatened the ruin both of themselves and their adversaries. Mainly through the ottices of Godolphin, the rivals were brought to agree to share their profits, and six years later, in 1708 , the two were amalgamated, as the "United Company of Merchants of England Trading to the East Indies," a body which speedily" came to be known by the familiar appellation of "John Company." It endured, as a political power, for a hundred and fifty years, until, as a result of the Mutiny of 18.7, the govermment of India ras taken over by the British Crown. As a trading corporation, it existed until 1873. 
English and Dutch at Sea.--As already indicated, the Duteh were the greatest rivals of the English in the East. Mainly through the wealth gained in their eastern trade, the Dutch had, by this time, become the first nation in Europe. Their fleet was greater than that of all the other European kingdoms together, and in 1672, we find them strong enough to defy the united power of England and France, while the spirit of commercial enterprise, reflected on the national life, gave a marvellous stimulus to art, learning and industry.

After this, however, a long series of disastrous wars against England, France and Spain, brought about a decline in the importance of Holland, and a consequent lessening of her maritime and colonial power. The knell of Dutch supremacy in the East was sounded by Clive, when, in 1758, he attacked them at Chinsurah both by land and sea, and forced them to an ignominious capitulation.

England and France.-The Dutch colonies had been managed on strictly commercial principles. The welfare of the inhabitants and indeed of the settlers, was in every case, subordinated to the desire of gain. The trade was in the hands of companies of merchants at home, and these must have their dividenàs whatever befell. As a result, Holland quickly lost the supremacy she had wrested from Portugal, and France replaced her, as England's great rival in India. Indeed, the constant warfare between England and France during the eightecnth century, was, in the main, the outcome of their commercial and colonial rivalry. A French East India Company had been founded in 1604 , and this was followed by other companies in $1611,1615,1642$ and 1644 . In 1719, the East India, the West India, Senegal and China companies were analg:mated under the title of the "Company of the Indies "a corporation which was only finally abolished by the National Asscmbly in 1796 . 
The earlier part of the eighteenth century was ind well the most flourishing period of French colonisution. Her ministers, quick to recognise the potential benefits to be derived from the possession of colonies, were liberal in their support and curcful in their regulation. In England, on the other hamd, the government, up to the time of Charles II., had taken no official notice of the colonies. Then a Committee of the Drivy Council: "The Committee of Trade and Plantations," was formed, but the Stuarts took little or no interest in the welfare of England beyond the seas, and it was not until the reign of William III., that the British colonies received any adequate measure of government support. Hence, while British power in India grew as a result of the efforts of the Company's servants. French influence. supported by the government, developed at a far more rapid rate. Before entering upon the great duel between Englund and France for the Empire of India, it will be desirable to glance for a moment at the condition of India, and the circumstances which made it possible for a band of aiventurers, for the most part untrained to war, to conquer a country of such immense size, so great a population, and such rast resources.

The Mogul Empire.-Enelosed on two sides by the sea and shut off from the continent of Asia on the north by the impassable barrier of the Himalayas, it would almost scem as though India was secure against invasion. But the rast barrier of the Himalayas is vulnerable at one point, and the whole history of India, up to the time when Vasco da Gama discovered the sea-route to it round the Cape of Good IIne, centres in the successive waves of invasion which rulled through Afghanistan and the Himalayn passes over the feltile plains of the north and north-west.

Chief among these inroals is that of Mahmoud in 1001 A.D. This leater, by birth a Turk, by religion a II hammelan, and by disposition a fanatic, conceired the idea of converting India 
to Islam; and for five centuries, he and his suceessors continued the promulgition of the Mohanmedan faith, and claimed the title of Lords of All India. With the invasion of Baber, in 1524, was laid the foundation of the great Mogul Einpire. By the middle of the sixteenth century, the rule of the Moguls had been extended to cover almost all northern India. The Dekhan remained, however, unconquered until the time of the Great Emperor Aurungzeb, who swept over it like a devastating scourge in $16 S 3$.

His conquest was at once the high-water mark of the Mogul power, and the commencement of its fall. The tribes of the Delihan were of vastly different fibre to the effeminate races of the northern plains, and their princes, roused by his cruelty and the oppression of his rule, bauded in the great Maráthá confederation to shake off the Mohammedan yoke. While their eonqueror lived, they could make but little head way and remained nominally subject to his rule. At his death, the power of the Mogul rapidly deelined. His suecessors possessed neither his military genius nor his administrative ability, and the Maráthás steadily grew in extent, in power, and in independence.

On the north, too, the empire suffered. Here the warlike Afghan tribes, swept down, time after time, by the path the Moguls themselves had made, while, in 1739, Shah Nadir of Persia swooped upon Delhi, their capital, sacked the city, and carried off booty to the value of $£ 32,000,000$ sterling. The blow praetically ruined the empire and left the Maráthás the masters of India. Their ascendency was, however, by no means universal or secure. Powerful Hindu princes, swaying vast territories, still held aloof from the confederation or took arms against them, openly denying the supremacy of the Peshwá, and asserting their own independence. Thus at the very time when the relations between the English and French traders in India became strained to the breaking point, the 


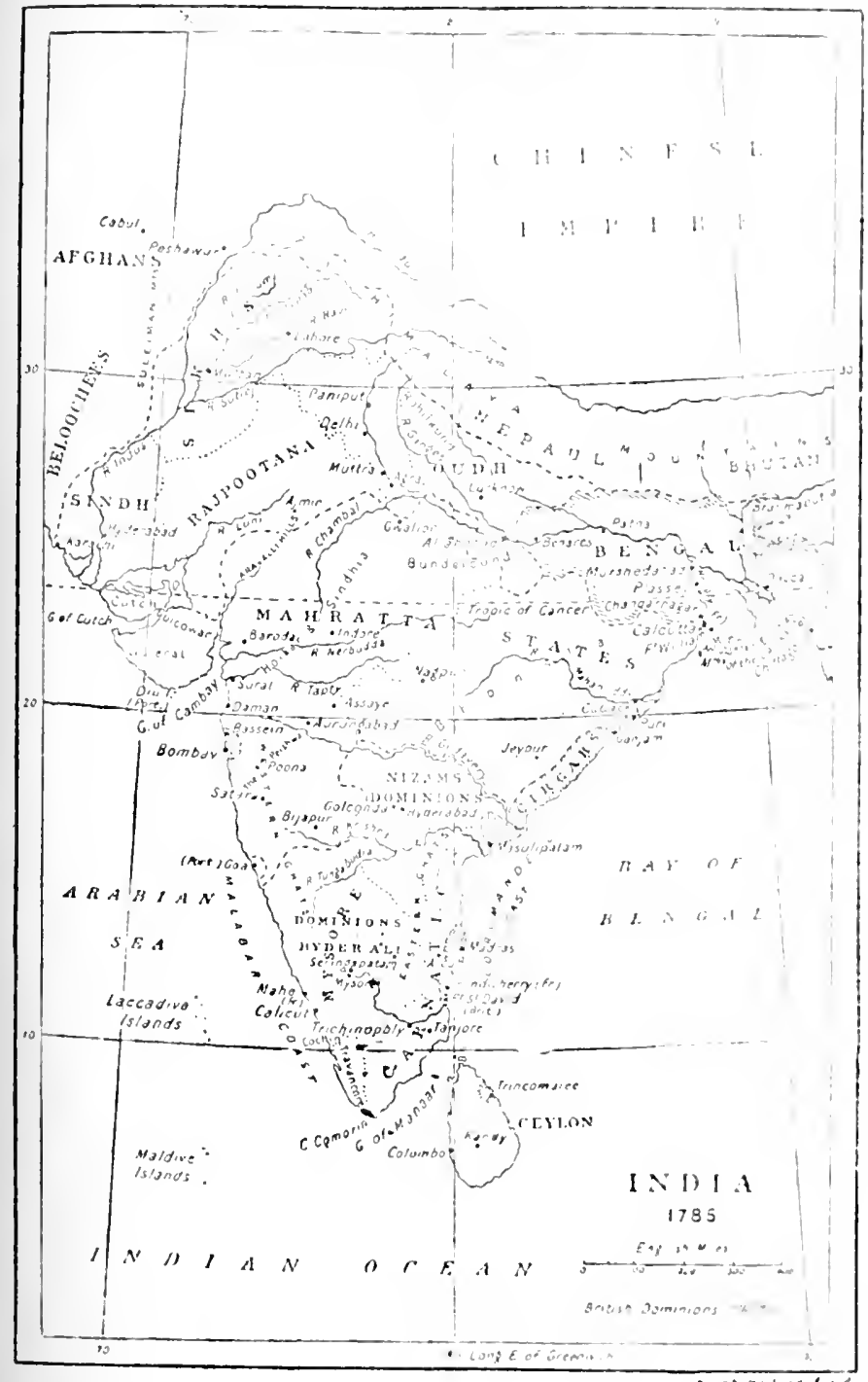

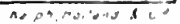


country itself, in lieu of being a united nation, capable of presenting a common iront to an invader, was merely a con. glomeration of states. eitier passively indifferent or openly hostile to one another, and with no common ground of nationality, interest or religion, on which they could unite. It is to the state of anarchy, which existed in India in the eighteenth century, that we must attribute the ease with which the British empire was founded against such overwhelming odds.

THE FRENCH IN THE KARNATIK.-The Anglo-French Struggle (First hase).-The disorder incident upon the down. fall of the Mogul Empire was greatest in the south-east. Here, too, the English and French traders had their chief stations. At home, the peace policy of Walpole was being gradually broken down and the relations between England and France were becoming more and more strained, until, in 1744, the War of the Austrian Succession yielded place to a definite contest between England and France. Although the l'eace of Utrecht had made England Mistress of the Seas, she was not, so far, a match for the united strength of France and Spain, the one striving to attain the sovereignty of the seas and the other to retain something like her old supremacy. For the moment, France beld the upper hand in eastern waters and Labour. donnais, the French governor of Mauritius, sent a fleet against the British stronghold of Madras, besieged Fort George, captured it and held it, with its garrison and stores, to ransom, pledging his honour that a moderate sum only should be exacted.

His success roused the jealousy of his superior in the Indies-Dupleix, the governor of Pondicherry. The latter, a man of immense ambition and overweening vanity, interposed, chose in his spleen to ignore the terms of the capitulation, rased Fort George to the ground, carried the prisoners in 
triumph to Pondicherry, and, without the formality cf con. sulting the native ruler, added Marras to the French dominions. The Nawib of the Karnatili, wroth at this summary annexation of his possessions, gathered an army of 10,000 inen and marched against the French, only to find his forces routed with the utmost ease by a body of 250 French troops aided by some 700 scpoys (sipáhis), armed and dis. ciplined after the Europcan fashion.

The victory of St. Thome is the key to the conquest it India. It proved that the great armies which the Indian princes might bring into the field were of little avail agdinst Europeans or troops under European Duplelx. discipline. It showed Dupleix what he had long conceived, the possibility of found. ing a great French empire in India upon the ruins of the petty native kingdoms. For a time, Fort St. David becane the beadquarters of the British power in the Karnátil. Dupleix, stimulated by his success at Madras and bent upon driving the English from India, now pat forth all his efforts to crpture it. In 1748, however, an English theet, under Boscawen, succeeded in relieving it and turned the tables by besieging Pondicherry. Before any definite issue had been arrived at, news came of the Treaty of Aix-la-Chapelle. Peace was nominally settled: all conquests mutually restorcd. But the enmity was as bitter as ever. Open hostilities were impossible, but the endless quarrels of the native princes offered an outlet for the racial and commercial hatred that daily grew more bitter between the tradcrs.

The Anglo-French Struggle (Second Phase).-If English and French in the Karnatik dared not procced to open war while the mother countries wore at peace, they might at least gratify their hatred by siding with the quarrels of the rival princes. Dupleix, in particular, saw in this a means of gratifying his ambition and proposed, should oceasion offer. to 
officer with Europeans the army of the native prince with whom he sided. In this way he hoped to gradually consolidate a force capable of defeating any army that could be brought against him, and of ousting the only rivals able to defeat his purposes.

Opportunity lent her aid to his ambitions. In the year 1719, died Azaf Jáh, the Nizám or Viceroy of the Dekhan. His possessions descended to his son Nazir Jang. The Karnátik, the wealthiest of the provinces tributary to Nizám of the Dekhan, was ruled by the Nawáb Anwáru'din. There were, however, pretenders in the field who sought to oust both the Nizám and the Nawáb. These were respectively Salábat Jang, grandson of the late Nizám, and Chandá Sáhib, a son-in-law of a former Nawáb. These agreed to unite their interests, invaded the Karnatik, and invoked the aid of the French.

Dupleix seized the opportunity with aridity. He saw nimself, in imagination, ruling the whole of southern India. The Nizám of the Dekhan and the Nawáb of the Karnátik, indebted to him for their thrones, would, of necessity, be as wax in his hands. He sent four hundred French troops and two thousand sepoys, well armed and well disciplined.

The victory that ensued was due, to a great extent, to their valour. Anwáru'din was slain, his son Muhammed Ali, with the remnant of his army; tled to Trichinopoly, the Nizám was shortly afterwards assassinated by his own followers, Salábat Jang and Chandá Sáhib were enthroned at Haiderábád and at Arcot respectively, and French influence was paramount in the Delihan.

Dupleix was the greatest man in India. He assumed open equality with the Nizám. Privately he claimed to be his superior. He took the title of "Governor of India from the Erishna to Cape Comorin," acquired vast wealth and exercised unbounded influence. 
The English had offered little opposition. They had, mdeed, supported Muhamued Ali, the son of Amwiludin, who had assumed his father's title of Nawáb of Arcot. Jut his flag Hew over Trichinopoly alone, and here he was rigorously besieged by Chandá Sábib and his French allies. Mis position seemed hopcless and with his fall would go all hopes of an extension of the British power in India. The native princes, who had seen with awc the success of the French, had learned to look with something like contempt upon the easily vanquished liritish, and no aid night be anticipated from this quarter. Still some attempt must be made. Jlelay uxeant ruin. The traders at Madras succeeded in raising a body of some two hundred English and three hundred sepoys. The question now was how to employ it.

To attempt the relief of Trichinopoly, with such a force, was absurd. The difficulty was solved by a youth-Robert Clive-formerly a writer in the Company's service, but now employed in a half civil, half military capacity as commissary to the forces. At his advice it was resolved to effect i diversion by attacking the Nawáb's capital, in the hope that to save it, he would abandon Trichinopoly. The plan was entertained and its execution entrusted to

Clive at Arcot, 1731. Clive himself. The scheme worked to a marrel. The garrison of Arcot, surprised in the midst of a great storm, fled from the fort without a blow. Clive entrenching himself behind its walls, prepared as best he could, to meet the siege he knew would follow. Day. light showed his weakness, and the troops which had tled in dismay before his approach, now rallied, roused the surromiling country, and to the number of three thuusand men, closely inrested the place. Clive, by a night surprise, put them to utter rout, slew great numbers and returned to his camp; without the loss of a man. New's of these proceedings reached Trichinopoly and the Nawáb detached four thousand troops, 
under the commani of his son Rájá Sáhib, for the recapture of his capital. These, reinforced by two thousand men from Vellore and by a detachment of French troops sent by Dupleix, swept into their ranks the remnants of the fugitives from Arcot, marched to the capital, surrounded it, and the siege began.

The history of the siege is one of the most memorable episodes in Indian history. The garrison consisted of one hundred and twenty Europeans and about two hundred sepoys. The general was a youth of twenty-five,

\section{The Siege}

of Arcot, 1731 . with no previous military training. Pro. visions were scanty, walls falling into ruins, battlements too low to protect from the enemy's shot. Yet, for fifty days, the garrison held out. The young commander displayed a wariness, vigilance and skill, that would have done credit to a reteran commander. But the number of the defenders grew daily less, the small stock of provisions dwindled, the breach grew Fider and an attempt at relief failed. Yet the spirit of the garrison never wavered. In lieu of the dissensions that might have been expected in a body of mixed nationality there was displayed an unparalleled unanimity. The sepoys in particular showed a rare devotion, and a dog-like fidelity to Clive. When all hope seemed gone, help came and from an unexpected quarter. A bods of troops had been hired from the Maráthás to assist Muhammed Ali. Considering his cause hopeless, these had remained massed upon the frontier of the Karnátik. To them, imbued as they were, by the French triumphs, with something like contempt for the English arms, the stubborn valour of Clive's defence, and the reckless daring of his attack came with the force of a revelation. The heroism of the defenders stirred their hearts. These, at least, were men, and they moved formard to the rescue. Rájá Sálib, apprised by his spies of their approach, attempted by bribery and threats to cajole Clive 
into yielding. Both were vain. The Rájá determined upun a tinal attempt. Religious enthusiasm and drunken daring were involsed to lend their fury to the attack. The besieged met it with the courage of despair. Three times the Rajá's troops swept in desperate onset against the fort: thrice they were rolled back, brolien and defeated. Neither fanaticism nor intoxication availed against the steady bravery of the defenders and the watchfulness and cool courage of Clive. The attack had lasted only for an hour, but that honr hal cost the besiegers four hundred men. Morning dawned on an empty camp. The Rájá, with his arıny, was in full retreat. The news of the exploit thrilled the English with hope, its fame raised Clive to the rank of a leader of men. A little force of two hundred Europeans and seven hundred sepoys was raised, and with them as his command Clive once more took the field. The Rájá was defeated at Arni and Coverpák; the French at Conjeveram, Covelong and Chinglepat, while the besiegers of Trichinopoly were, in their turn, besieged, and were forced at the end of two years to capitulate. Chándá Sáhib fell into the hands of the Marathás and was put to death, and the English canlidate, Muhunnned Ali, was firmiy seated on the throne of the Karnatik as Nawáb of Arcot. Dupleix, viewing with dismay the failure of his plans and smarting under the disgruce of his defeat, refused to reconnise the English choice and laid schemes for further war. But he had to bear the stigma of failuro. Enemies accused hin at home. His employers repudiated his schemes; the merchants. who would have gained by their success, united in reviling him; the matter of the succession to the throne of the Karnátils was referred to the home governments, and decided against him; he was superseded in his command, and returned to Europe to die in poverty and disfrice. His successor, Godelieu, signed a treaty recognising Wuhammed Ali as the Nawáb of the Karuátik, restoring all the possessions that 
Dupleix had gained, and agreeing to cease, for the future, all intrigues with native rulers.

Clive returned to Madras covered with honours, but with shattered bealth. His condition, in fact, made it imperative that he should return to England. Here he was the cynosure of all eyes; his victories were the theme of every tongue. He entered Parliament but only to be unseated on a petition, the costs of which, added to those of the election, had the effect of practically reducing him to penury. In these straits his thoughts turned to India again. The directors of the Company showed themselves nothing loth to expedite his return. War with France again seemed imminent, and neither the nation nor the Company could afford to lose the services of a "heaven-born general" like Clive. The directors appointed him governor of Fort St. David, the king gave him his commission as lieutenant-colonel, and in 1755 he sailed again for India.

The Anglo-French Struggle. (Third Phase.)-Hardly was the ink of the treaty reconciling the English and French interests in India dry, before the differences in America assumed so serious an aspect that war once more loomed imminent. The English in India prepared to renew the struggle. Before the threatened war was declared, Clive was once more in the field, this time against the native ruler of Bengal-Siráj-ud-Daulá (Surajah Dowlah). This potentate was a youth of eighteen, of weals temperament and ungovern. able passions, whom unbridled licence had reduced to little better than a wild beast. He had inherited, against the English, a prejudice whose violence was equalled only by his dread lest they should encroach upon his dominions and authority.

The fear was now a lively one. The English of Calcutta, in expectation of the outbreak of hostilities with the French, had commenced to fortify their settlement, by deepening the 
Maráthá ditch-a relic of the time when Bengal was periodically harried by the warlike tribes of the upland districts. A pretcxt only was needed for the Nawáb to attack the settle. ment-from the looting of which, moreover, he anticipated great gain. The pretext was soon found. It chanced that a native, a relative of his own, whom the Nawáb had desired to plunder, had fled for refuge to Calcutta, and had not been given up by the governor immediately on demand. Siráj-ud-Daulá raised a great army and marched towards Calcutta. The residents were mere traders. They had not, like their confrères in Madras, been schooled to arms by constant quarrels with the French, and continual bickering with the native rulers around therw. Noreover, tales of the Nawáb's cruelty had preceded him and his dislike to the English was well known. The governor, with many others, Hed, tine few who remained found it impossible to maintain their wall for more than four days. The fort surrendered and its defenders, to the number of one hundred and forty-six, fell into the hands of the Nawáb.

These were confined for the night in the military prisonthe "black hole," a name which has won a terrible significance in the record of horror, as the Black Hole of Calcutta. The prison was some eighteen feet square, it had two small windows for ventilation, and the time was June. The

The Black Hole of Calcutta. wretehed prisoners, protesting vainly that it could only be a joke, were driven into it at the point of the sword. Then the doors were closed. The horror of that night has never been surpassel. The eaptives after vainly appealing for mercy and offering fruitless bribes to their gaolers, fought ench other under foot, in their struggles to get to the windows. The guards, fit subjects of their master, looked placidly on at their struggles, jeeringly refusing to disturb their ustster, without whose orders 
nothing could be done. The stifling heat of midsummer added to the terror of suffocation the madness of thirst; the scene baftles description.

In the morning twenty-three spectres staggered out to testify to a crime wbich thrilled all India, as its memory even now thrills the world with horror. Clive, hastily collecting a thousand men, took ship for Calcutta. He landed in December. The Nawáb, already feeling, in the loss of his revenues, the folly of oppressing the English traders, was cowed by the vigour of these measures into making overtures for peace. Clive would have preferred to decide the matter, once and for all, at the point of the sword. He was, however, but the servant of the Company, his superiors had already decided to treat, and he had perforce to change his rôle. From a general he now became a diplomat. He was equally successful but his success won him notoriety in lieu of fame. He appears to have been imbued with the idea that, in eastern diplomacy, nothing would serve but to meet the natives with their own weapons of treachery, falsehood and deceit. Thus though in his private dealings, one of the most honourable of men, he displayed in the course of his negotiations with the Hindu rulers a duplicity in no degree less than their own.

A nominal peace was patched up with Siráj-ud-Daula, but that prince showed himself in no wise to be trusted, and Clive determined upon his deposition. A plot was hatching to dethrone the Nawáb and to confer the crown upon the leader of his troops, Mír Jáfar. Clive induced the English leaders to lend their support, and, while flattering the Nawáb into security, took steps to secure his downfall. The Nawáb's own treachery accelerated his fall. The French had a settlement at Chandernagar. He opened negotiations with them, while still professing the utmost friendship for the English. Decisive measures became necessary. An expedition was sent against Chandernagar, Clive being in command by land and Admiral 
Watson by sea. The success of the movement wis complete. The settlement with all its stores fell into the hands of the Coglish, and its garrison, including five hundred French troops, became prisoners of war. Then, changing his tone, Clive wrote to the Rájá complaining of his duplieity and announcing his deter. mination to exact, if necessary by force of arms, redress for the injuries the Company and its servants had received at its hands. For reply the Riaji assembled his forces, unarched to Plassey, and there entrenched himself to await erents.

Mir Jáfar, who had agreed to desert with all his troops, now hesitated and temporised. Clive was in a dilemma. Whatever advantage European troops might hold over the native armies, the position was a serious one. He had to oppose, with a thousand European troops and two thousand

The Battle of Plassey, 1757. sepoys, an army consisting of some thirty thousand foot and, worse than all, fifteen thousand lorse, drawn from among the warlike races of the northern hills. Through a whole morning he lay on the defensive, repclling attack after attack; then, when the Nawíb's troops drew off for refrcshment, Clive assumed the offensive, and by a sudden onslaught threw the whole camp into confusion. The attack was pressed home, many of the most prominent of the Nawáb's officers were slain, and the ruler himself, lending a ready ear to suggestions of Hight, which accorded only too well with his own desires, left the field, and the whole army foll into a panic. Mir Jafar, whose prudence seems to have exceeded his valour and who had hitherto held aloof, now threw his troops on Clive's side and the victory was won. Plassey male "John Company" master of Northern India. True, Mir Jífar occupied the throne, but it was as the Company's nominee and at the Company's good pleasure.

From Mir Jáfar, on his elevation, the Company proeeeded to exact compensation for the misdeeds of his predecessior. 
Vast sums were claimed, amounting in the aggregate to no less than $£ 2,700,000$. The treasury did not contsin sufficient to meet half these demands, and the Company, to meet the deficiency, was granted a Zamindiri, or landholder's right, over an extensive tract of land around Calcutta. Clive, two years later, received from the Nawáb the right to the land-tax (Jagir) of the same district, a right which practically made him owner of the soil and thus the overlord of his own masters the "Company." $\mathrm{He}$ also accepted treasure to the amount of about $£ 250,000$, a fact which was utilised against him at his trial in England, after his return, in 1760.

In spite of his pliancy the new ruler was not a success, and was speedily superseded by his son-in-law, Mír Kásim. The latter was a man of independent character and strong abilities, qualities which brought him into conflict with the ofticials of the Company, whose proceedings, particularly in the collection of the inland dues claimed by the Company, certainly did not err on the side of justice or leniency. The Nawáb protested that the Company's servants habitually disregarded his authority : the Gorernment turned a deaf ear. The Nawáb thereupon abolished all the inland duties in dispute, thus placing the Company, as regards trade, on the same footing as his own subjects. The Company refused to resign its privileges and the quarrel daily waxed more bitter. The climax came when the Nawáb's officers fired upon an English boat. Then all Bengal flew to arms against the traders.

The Massacre of Patna, 1763. Some two thousand sepoys, in the service of the Company, were surprised and massacred at Patna and about two hundred Englishmen killed in other parts of the presidency. The rising was vain. As before, the arny of the Nawab could make no stand against the disciplined valour of the Company's troops, aided as they were by the prestige which attached to the British arms. Mir Kásim, defeated at Gheriah and Udba- 
nala by Major Adams, fled to Oudh and cluimed the hospitality and protection of the Nawáb Wazir, who, first refusing to give him up at the demand of the Company, ended by openly espousing his quarrel in the field. To add to the danger, symptoms of disaffection appeared among the Company's own troops, which after smouldering for a time broke out into the first Sepoy Mutiny (1764). The Nawáb was, however, decisively defeated by Major Mumro at Baxar (1764); the vietory added Oudh to the dominions of the Company and brought its ruler, after ineffectual endeavours to obtain aid from the Marithás and Afghan chiefs, a suppliant to the English camp.

Clive's Administration in Bengal (1765-1767). - In 1765, Clive, now Baron Clive in the peerage of Ireland, returned to India for the third time, with the rank of Governor-general of Bengal, and with a firm determination to earry out certain reforms of the first importanee, both in the administration of India and in the Company's service.

Clive's administrative reforms took form as a system of dual control, by which the native princes were to retain the control of army and police, law and justice, while the Company undertook the fiscal administration of the provinee, receiving the revenues, which, however, were for some time collceted by native officials, and paying over a sum of $£ 600,000$ to the Nawab, and half that amount as tribute to the Grand Mogul. Abuses whieh sprang up under this new system were, however, so great is to conpel

The Treaty or the Company to take more and more of the Allahábád, 1763. government of the province into its own hands. The reform of the service was an even more scrious matter. The Company's servants had always been insulticiently paid, and had been accustomed, with the cognisance of their masters, to supplement their incomes by engagin: in 
private trade. Much of the iuterual trade of the province had fallen into their hands, and was carried on for their private benefit, while the collectors rapidly amassed fortunes by the most ruthless extortions from the natives. Even more questionable means were employed. Bribery was rife and the high officials of the Company habitually made large sums by their exactions from the native princes. It was this state of things that Clive now set himself to remedy. It may be innagined that the task was one of the utmost difficulty. Yet in the face of the strenuous resistance of the whole service and an actual mutiny of some two hundred of its members, the reforms were carried. Salaries were increased with the money raised by the imposition of a tax on salt, and the servants of the Company were forbidden to receive gifts from the native princes or to engage in private trade.

Clive's reforms aroused vast opposition, not only in Indis but in England, and this opposition frustrated many of his designs for the consolidation of the British power. In 1767, he returned to England for the last time. There Indian affairs were beginning to take fast hold upon a certain section of the parliament, and his enemies found it an easy matter to move a vote of censure upon his conduct during the period of his administration. Chief among the charges were the treachery attendant upon the deposition of Siráj-ud-Daulá: the drawing up of a fictitious treaty with Mir Jáfar for the purpose of deceiving a Hindu-Omichand-who had threatened to betray the plot against the Nawáb, unless he received an immense reward: the forgery of Admiral Watson's name to this treaty: and finally, the enormous gifts he had received from Mír Jáfar.

A stormy debate ensucd. At its close, the Commons found that Clive had received vast sums, and that to do so was illegal. Here they stopped. The events had happened sixteen years before. Clive's later administration had done much to rcdeem them. He had since had many opportunities of 
increasing his fortune and had held his hand. Moreover, was he not the saviour of India? The Housc refused to say that he. had abused his powers to his advantage, and instearl, passerl a resolution to the effect that "Robert Clive dir, at the same time, render great and meritorious services to his country." The effect of the struggle was, however, lanentable. The stress of the parliamentary conflict unhinged a inind which had already shown a tendency to mental abcrration, its bitterness left him a prey to a settled inelancholy, a painful disease aggravated the evil, and in 1774 , the greatest of English generals since the days of Marlborough, died by his own hand.

The Anglo-French Struggle (Fourth Phase). While Clive was consolidating the British power in Bengal, the French were maling strenuous efforts to recover their supremacy in the Karnátik. A powerful French fleet had foreed its way past Admiral Pocock at Pondicherry, and had The War in the landed the Comte de Lally, an Irish
Karnatlk, 1758-81. adventurer in the French service, who had been recently appointed to the supreme command in the East Indics. The vigour of his proceedings and his slill in the icld earned him a temporary suecess. Fort St. Divid was capturcd, and Madras besicged. The defence, in the hands of Clive's old colleague and commander-Major Lawrence, was so ably conducted, that after wasting two months, the French were forced to retire. Meanwhile Sir Eyre Coote had nrrived from England, and lost no time in carrying the war into the enemy's country. Wandewash was stormed and I'ondicherry besieged. Marching to its relief, Lally was net at Wandewash by Coote and utterly defeated. The victory gained Fingland the combul of the Karnatik. Lally, retreating, threw himself within the walls of Pondicherry, but was compelled to eapitulate in 1761, and with his surrender ended the French power in Inhla. Lally was sent as a prisoner to England. but wis liberated on 
parole to go to Paris, there to meet accusers who desired to make him the scapegoat for the non-success of the French East India Company. He was tried for his failure, and beheaded in 1766. Twelve years after his death his sentence was formally reversed.

Thus had the French East India Company, within a few years destroyed the only three eminent inen who bad ever been placed at tho head of their affairs in Inlia-Labourdonnais, Dupleix and Lally. It did not long survive this last display of its imbecility and ignorance.-MILL (" History of British India.")

Haidar Ali. The success of the English against Lally resulted in the acquisition of great prestige and considerable territory. Further, their alliance was now eagerly sought by the native princes. An agreement had been made with Nizam Alí of Haiderabad to oppose Haidar Ali, a

First Mysore War, 1780 . soldier of fortune who had risen to the rank of Sultan of Mysore-the price to be paid for English aid being the cession of the tract of territory, known as the Northern Sirkars. Out of this sprang the first of our wars with Mysore, which ended ingloriously enough, in 1769, by treaty, on the basis of a mutual restoration of conquests and a defensive alliance. An invasion of the Maríthás led Haidar to appeal to the British, now his allies, for aid. Nothing could have been more distasteful to the rulers of the Company. The demand passed unheeded, and Haidar bitterly resented the breach of faith. An opportunity for revenge occurred. In 1780, war again broke out between England and France. Mysore was swarining with French adventurers and Haidar gladly accepted their proffered assistance in drilling his troops. In July the storm burst. With 90,000 men, largely officered by Europeans, many of them adventurers of the most desperate type, Haidar swept down upon the Karnátik, devastating a huge arca round Madras. The British forces available, could offer no effective resistance and had, perforce, to retreat before 
the formidable foe. Arcot way cuptured and the remaining strongholds invested; a French fleot with re-inforcements was daily expected, and the Inglish power in the Karnátik seemed to totter. The situation was saved by the energy of the governor-general, Warren Hastings, and the brilliant military ability of the veteran Sir Eyre Coote. An army of sepoys was raised and with these, together with a few Europeans, Coote encountered Haidar's huge army, and defeated it in the great battles of Porto Novo, Pollilore, Sholingur and Arui. In the following year Haidar died, and Tipú, his son and successor opened negotiations for peace, which were completed in 1784 .

The Goxernment and the Company.-The continual warfare had so reduced the income of the Company that, in 1772 , it found itself unable to pay its dividend and appealed to the Government for assistance. A committee was appointed to enquiro into the matter, and its report showed the Company to be on the verge of bankruptcy. Moreover, such a record of maladministration, cruelty, oppression and frand was brougint to light as made England ring with indignation.

The reguired aid was granted but only on certain conditions, embodied in the Regulating Act of 1773, which placed the Company's affairs more directly under control of the Crown. The administration was to be in the hands of a GovernorGeneral aided by a coumcil of five, all of whom were, in the first place, to be appointed by the Crown. The first of the Govemor-Generals thus appointed was Warren Hastings.

Warren Hastings had entered the East India Company's service as a clerk in 1750 . He was one of the prisoners captured by Siráj-ud-Daulá at Calcutta, but escaped, Hed to Clive, and carried a musket at Plassey as a volunteer in his ranks. Clive, quick to discern merit, appointed him British resilent at the court of Mir Jáfar. In 1761, he was made a member of the Council, end three years later retired to England with 
a moderate competence. The loss of this sent him as a suppliant to his old directors, who willingly re-engaged him in their service and sent him back to India, in 1769, as a member of the Council at Madras. In 1772, he was appointed Governor of Bengal, and, with the passing of the Regulating Act, took his place in 1773 , as the first Governor-General of India.

He set himself the task of consolidating the Company's authority, and, what was of no less importance at this critical stage of its history, of increasing its revenue. Had the latter decreased at this juncture, the British power in India must have fallen. Some of the measures he adopted, however, aroused great indignation. Certain of them admit of no palliation, and for these he was, in after years, brought to trial before the House of Commons.

Among the chief of the crimes laid to Hastings' charge were his extortions from Chait Síngh, Rájá of Benares, from whom he demanded subsidy after subsidy, until the prince was compelled to refuse further supplies. His refusal was treated as a crime and punished by the confiscation of the whole of his possessions. The affair ended in a dangerous revolt, which, however, Hastings subdued. The Rájá fled, his treasury was looted, and his dominions added to the Company's territory. But the money found in the treasury of Chait Singh was appropriated by the victorious troops, to whom, as prize money, it legitimately fell. Hastings' plight was as bad as ever. It became necessary to find some other means of raising the funds, now more necessary than ever, for the maintenance of the British rule in India against the attacks of Haidar Ali and the French in the Karnátils. Further victing were found in the persons of the Begams of Oudh. The late Nawib had called in the aid of the British troops against the Rohillá Afghans. Part of the subsidy agreed upon for this had not boen paid. But the Nawáb was dead and the 
bulk of his property was in the hands of the Beganus-hin mother and his wife. The present Nawíb had exhausted his resourees in vicious living, and the Bengal Council had hai to intcrifere to prevent his exacting money from the litginus. Hastings now proposed that he should demand from them the surrender of their treasures. They refused and were imprisoned. and some of their servants were tortured into compliance.

Much of the difliculty experienced by Hastings in bis dealings with the natives arose from the opyosition he met with from the members of the Council, notably Sir Ihilip' Franc1s-the reputed author of "The Letters of Junius"-with whom be fought a duel, the result being that Francis was so severely wounded as to be obliged to return to England.

Hastings himself returned in 178.5 , to meet with an enthusi. astic reception. But the abuses of his administration hal so impressed eertain members of the Commons, that they resolved upon his impeachment. The triai that

The Trial of Warren Hastings. followed, and which lasted for seren years, is one of the most famous in our history: It resulted in his practical acquittal. The House, generously, refused to visit with its censure one who had wrought so much for the British name in India. The immense cost of a trial extending over a period of seven years, bowever, com. pletely exhausted his resourees and he was, for the reminder of his life, dependent upon the bounty of his former masters - the Company-a bounty which, to their credit, was never denied.

Apart from his beving saved the country from the French and from the inroads of Haidar Alí, Hastings' great claim to fame rests on his administrative work. He had reorganiscu the Company's service, reformed the method of collecting the revenue, established courts of justice, and created some semblance of a police. History, howerer, sometimes forgets these admirable achievements and remembers only hl:s bold 
and aggressive policy for the advancement of the Company's power and the crimes to which it led.

The rule of his successor, Lord Cornwallis, was chictly remarkable for its fiscal reforms, and the permanent fixing of the Bengal land rents. It was the governorship of his successor - Lord Mornington, better known as the Marquis of Wellesley - that marlis the real commencement of British empire in India. Two principles dominated his policy; the first to crush for ever the French hopes of an Indian Empire, and the second to make the British power paramount throughout the peninsula, allowing the native princes to retain the insignia of royalty only on condition of acknowledging their political dependence upon Britain. Hitherto, the struggles which had taken place in India had been for the purpose of defending the Company's trade or possessions. These still continued in the southern portion of the peninsula as the Mysore Wars. Now, however, in addition to them there began a new series of wars of acquisition, waged chiefly against the warlike peoples of Northern and North-western Inlia.

The Mysore Wars.-The peace made by Tipú Sultan, son of Haidar Al, was not of long duration. The imagination of Napoleon had been fired by dreams of an Indian empire, and French emissaries swarmed throughout India to prepare for the mighty invasion which was to be led by the Emperor in person. Tipú, in particular allowed himself to become the creature of the French, and even went so far as to plant a "tree of liberty" in his dominions, and to enrol himself in a republi. can club as Citizen Tipú. But Bonaparte got no further than Egypt. The threatened invasion did not take place, and the result was the invasion of $\mathrm{My}$ sore by a British force, organised by Lord Wellesley in person and led by General Harris. The Sultan's forces, after the feeblest resistance in the field, were 
cooped up in Seringapatam, the town was brilliantly stormed and Tipú died like the son of his father, fighting valiantly in the breach. His dominions were parted; the old statc of Mysore was restored to its ancient Rájás from whom it had been reft by Haidar Ali, and the remainder apportioned among the British, the Nizím and the Maríthás, while the dependency of the Karnatik, together with the provinee of Tanjore was added to the British dominions, forming, with Madras, the Presidency of Madras, much as it exists to-day.

The Marathá Wars.-By this time, the great Maráthá confederation had begun to break up, as a result of the contests between its leaders for supremacy. The nominal head-the Peshwá was, in 1802, defeated by Hollkar and forced to flee for shelter to the British territories. Whilst there, he was indueed to sign the treaty of Bassein, acknowledging British supremacy and granting a yeariy subsidy, secured on the rents of certain districts, for the purpose of maintaining those forees necessary for his protection. The other leaders of the Maráthás refused to ratify this agreement, and during the Governor-generalship of the Marquis of Wellesley, the second Maríthá war broke out. The campaigns which followed are perhaps, the most glorious in the bistory of British India. The Marathás were led by Sindhia and the Rajá of Nagpur and the English forces by Sir Arthur Wellesley (afterwards Duke of Wellington) and General Lake. Wellesley, in the Dekhan, won the famous victories of Assaye and Argaum and captured Ahmadnagar. Lake's campaign was equally brilliant. He defented the Maráthás in the pitched battles of Lásáwri and Aligarh, and captured Delhi and Agra. Before the end of 1803, both Sindhia and the Bhonsla Rájá of Nagpur sued for peace. Sindhia resigned all the territory north of the Jumna, and the Rájá ceded Orissa to the English and Berar to their ally the Nizám. Only the free-booter Holkar remained in the field, maintaining a guerilla warfare, and every now and then, raiding 
Malwá and Rajputana, and the remaining years of Lord Wellesley's administration were occupied with fruitless attempts to crush him. Still the Governor, during the six years of his rule had carried out almost all that he had set himself to do. The North-West Provinces were united under British authority, the Madras Presidency in the south-east existed in almost the same form as it does to-day, and the Peshwá-the head of the Maráthá confederation in the south-west-was compelled to acknowledge British anthority. Lord Moira, better known as the Marquis of Hastings, -the title he received as the reward of his labourscompleted Lord Wellesley's conquests in Central India. Under his administration, too, the Bombay Presidency was formed. Two great wars were included in the nine years of his rule, one against the Gúrkhas of Nepal, and the other the last contest with the Maráthás. The results were, the freeing of the inhabitants of the Ganges valley from the raids which brought the hardy Gúrkhas from their Himalayan fastnesses in a resistless flood upon the fruitiul plains, and the anneration of a vast tract of country to the Bombay Presidency, together with the formation of the nucleus of the present Central Provinces. The work of conquest was continued by Lord Amberst. The first Burmese War laid the foundation of British Burmah by the annexation of the provinces of Assam, Aracan and Tenasserim, already in the military occupation of the British, while a further expedition into Central India succeeded in storming Bhartpur-a stronghold hitherto fondly deemed impregnable-a notion which had become a standing menace to British power in Central India.

The Márảthás.--The Máríthá powers at this time were gre in number. The Peshwá of Poona was the head of the confederaoy; its other memb rs were the Gáilwár of Baroda, the Bhonsla Rájá of Nagpur and the two Chiefs Sindhia of Gwalior and Holkar of Indore and Malwa, who continually struggled for pre-eminence in Central India. 
The seven years' govermment of Lord William Bentinck added nothing to the territorial extent of British India, but will ever form an epoch of administrative reform. "He abolished," says Macaulay," cruel rites, he effaced humiliating distinctions, he gave liberty to the expression

Lord wlllam of popular opinion; his constant study was Bentinok, 1828-36. to elevate the moral and intellectual character of the natives committed to his oharge." Among the most memorable of his acts are the abolition of sati or widow-burning and the suppression of the Thugs, whose barbarous practice it was to lie in wait for the purpose of strangling unwary wayfarers. In 1833, the charter of the Company was revised, its monopoly of trade being withdrawn and itself reduced to little more than a department of the British Government. The year 1843 saw the addition of Sindh to the British dominions. The conquest was carried out by Sir Charles Napier-whose victory of Miáni, in which 3,000 British troops defeated 20,000 Baluchis is one of the unost brilliant feats of Indian history. There now remained but one of the great independent races of India, the Sikhs, a great religious sect bound together by the rules of a stern military discipline. Runjit Singh, Maharájá of the Punjab, and founder of the Sikh power in India, had organised an army, disciplined by Europeans, and filled with religious fervour to an extent unparalleled in history, save by Cromwell's Ironsides. He, himself, wisely refrained from coming into conflict with the British power, but after his death no successor was found to take his place. The whole power vested in the army and its chiefs burned to measure its strength with that of the British troops. Thus, in 1845, the whole force of some 60,000 men crossed the Sutlej into British territory. A British army under Sir Hugh Gough marched at once to the front, and within three weeks, no fewer than four pitched battles were fought at Mudki, Ferozshah, Aliwal, and Sobráon. In the last of these the Sikhs 
were hopelessly defented, driwcn back over the Sutlej, aid Lahore captured. By the terms of the peace which followed, the doáb between the Sutlej and the Rávi was ceded to Britain, and a British resident, Sir Henry Lawrence, appointed to tine court of Lahore. Sir Heury Hardinge, the then governor, returned to England with the title of Lord Hardinge in 1848.

He was succeeded by one of the ablest of the Indian Governors-General-Lord Dalhousie. His maxim " that the rulers of a country only exist for the good of those they rule" has ever since his time prevailed

Lord Dalhousle, in Indian politics. In spite of his desire
13 $18-1856$. for peace, however, circumstances forced him into two disastrous wars. An outbreak of fanaticism at Multan led to the Second Sikh War and the famous khalsa army, the "Ironsides" of the Sikhs, was called into the field with, at the first, disastrous results to the British arms. In the terrible Battle of Chilianwálla the British lost 2,400 men, and, although patriotic historians choose to term it a drawn fight, there is no doubt that British power here received one of its severest chccks. Peinforcements were sent from England but before they arrived, Lord Gough, in the crowning victory of Guzerat, had recovered the advantage he had lost, restored the prestige of the British arms, and all but annihilated the Sikh arny. As a result a large portion of the Punjab came under British rule, together with Nagpur, Ondh and several minor states. In 1852, the Second Burmese War broke out, and the whole valley of the Irriwadi, from Rangoon to Prome, was annexed to British India under the name of Pegu.

The Indian Mutiny, 1857.-Lord Dalhousie was followed by Lord Canning. The fabric of the British empire in India was now completely mapped out. But the policy of annexation which had been laid down by the Company, and conscientiously carried out by Lord Dalbousie in all cases where the natives 
V'ere ground down by the tyranny of their rulcrs, or the British rule promised to ameliorate their lot, had become distasteful to a large section of the population. Together with the introduction of scientific inventions, the steam engine and the telegraph, it was believed to be indicative of $n$ determination to destroy the old civilisation of the Hindus with the view of replacing it by that of Europe.

The native princes, the oppressors of India in the past, whose thrones and powers had fallen before the determination of the English rulers to secure the welfare of the people under their rule, were naturally the first to foment. the spirit of disaffection which was abroad. The native troops, too, which, trained and led by Europeans had been the instruments of the change, were induced to believe that all India had been conquered by their prowess and that the fear of them alone maintained it in peace. Now a rumour spread abroad of an insidious scheme afoot, to complete the subjugation of the native races by destroying caste. The army had been supplied with a new ritie, the cartridges of which, before being placed in the rifle, required to be bitten in order to loosen the bullet. It was spread abroad that these cartridges had been greased with the fat of pigs-an animal unclean alike to Hindu and Mohammedan, and to taste whose flesh meant to the former the loss of caste. 'The discipline of the sepoy army rapidly declined under this belief until only its semblance remained. Officers were openly insulted by their men, fires broke out nightly in the native cantonments and finally, on the afternoon of Sunday, May 10th, 1855, the sepoys at Meerut broke into open revolt, murdered their officers, massacred, in their fury, every European whom they could find, and rushed in a disorderly rout to the neighbouring city of Delhi, there to stir their fellows into foliowing their oxsiuple. 
The English army had been weakened by the appointment of many of its officers to civil posts of political importance. and those who remained seem to have acted with irrational irresolution. A strong will and a firm hand, at the commence. ment of the outbreak, might have saved India the horrors that followed. The European garrison at Meerut was a strong one and, efficiently led, might not unreasonabiy have expected to overcome the mutineers before they reached Delhi. The new's was sent to that city by telegraph, but that was all. Next day the troops of Delhi mutinied, the Europeans blew up the magazine and lled as best they could, and the revolt spread like wild fire throughout the North. West Provinces and Oudh, and so on into Lower Bengal. Europeans every. where suffered the cruellest and most shameful of deaths, or were suffered to live only to undergo a fate to which death itself would have been preferable. The Punjab alone was quiet. There the plans of the sepoys were anticipated by stern measures of prevention. It was fortunate, too, that the Silihs never wavered in their allegiance to Britain. Indeed, it was largely through the invaluable aid afforded by these warlike tribes that the revolt was so effectually checked. In addition to Delhi, the chief centres of the revolt were the cities of Cawnpore and Lucknow. The former was one of the greatest of the native garrisons of British India, the latter had been strongly fortified by Sir Henry Lawrence, the governor of Oudh, who had foreseen the coming storm. Near Cawnpore, too, was the palace of Dandhu Pánth, better known to infamy as Nána Sáhib, the adopted son and heir of Báji Ráo, the last of the Peshwás-the titular heads of the great Maráthá confederation. No one was more profuse in his expressious of loyalty to the British, and few were equally energetic in fomenting the revolt in private.

On June 6th he threw off the mask, put himself at the head of the rebels, and proclnived himself Peshwa of the Marátbás, 
signalising his new dignity by marching on Cawnpore. Ths garrison of the ill-fated city, comprising far more women and children than fighting men, withstood him during a siege of nineteen days and then, confiding in his promise of a safe conduct down the Ganges to Allahábád, yielded. No sooner were they embarked, than a murderous fire was opened from masked batteries along the banks upon the defenceless occupents of the boats. A single boat only escaped. The remainder were brought to shore after the fusilade and every man massacred save four, who, cscaping, swam the river under a hail of shot and sought the protection of a friendly rajá. The women and children-a hundred and twenty-five-were taken back to their prison, there to wait the captor's pleasure.

Meanwhile Havelock, with a little army of relief, was pressing forward under the burning sun with a heroic fortitude rarely equalled in the annals of war. On the 15th of July he was at hand. At the first sound of his guns the captives were massacred in cold blood, women and children together, by the order of Nána Sáhib. When Havelock's troops, storming through the city, entered the prison house, its courtyard swam with blood, while from the well in its centre the horror-stricken soldiers drew some two hundred bodies all warm, some still quivering with departing life. Few sights recorded in the history of the world can have equalled in horror the well of Cawnpore. Strong men sat and wept like little children, then, conquering their grief, swore a terrible vengeance upon the authors of so terrible an outrage.

The Relief of Lucknow.-Luclinow had been fortified in readiness for the outbreak, and when it occurred, as it did on May 30th, it found the Europeans prepared, and the 750 British troops in the city, after a gallant stand succeeded in driving the rebels towards Sitapur. The city thus remained in the hands of the British-the only 
post in Oudh. The fall of Cawnpore was followed by a determined attack upon Lucknow. The garrison made a gallant resistance. Thrice the mutineers attempted to carry the place by assault, but each time they were repulsed with heary loss. Famine, sickness and the incessant cannonade maintained by the rebels were, however, doing their work, and the defenders looked anxiously for relief. Failing that, death even was preferable to falling into the hands of the mutineers.

On September 22nd, Havelock, who with his relieving column had performed prodigies of endurance, stormed the Alambagh with his tired troops and swept through streets lined by the enemy, who kept up a constant fire from windows, loopholes and house tops, to the Residency, where the little garrison had finally entrenched themselves. Eren now, the forces under the command of the European generals were not sufficient to attack the investing army, with any reasonable prospect of success. All that could be done was to fortify a larger area of the town until a stronger force could be brought to the relief. The siege continued till October $10 \mathrm{lh}$, when Sir Colin Campbell reached the Alambagh, captured it, forded the canal and attacked the Sikandrubagh, the chief of the rebels' strongholds, and carried it by assault. Havelock with his little garrison marched out from the Residency to meet him. The force was still insufficient to risk a pitched battle and it was determined to return to Cawnpore and abandon, to the rebels, the Residency for which they had fought so long, and whose possession had cost them so dear. Before the departure, Sir Henry Havelock died from dysentery, and was buried in the Alambagh on the scene of his triumphs. Sir James Outram with 3,500 men held the Alambagh against all the attempts of the mutineers to recapture it, until the army returned, in the following year, to finally reoccupy the city.

The Alambagh was a walled garden on the Cawnpore road, which was strongly fortified by the rebels, who wade it ose of the chief of their strongholds. 


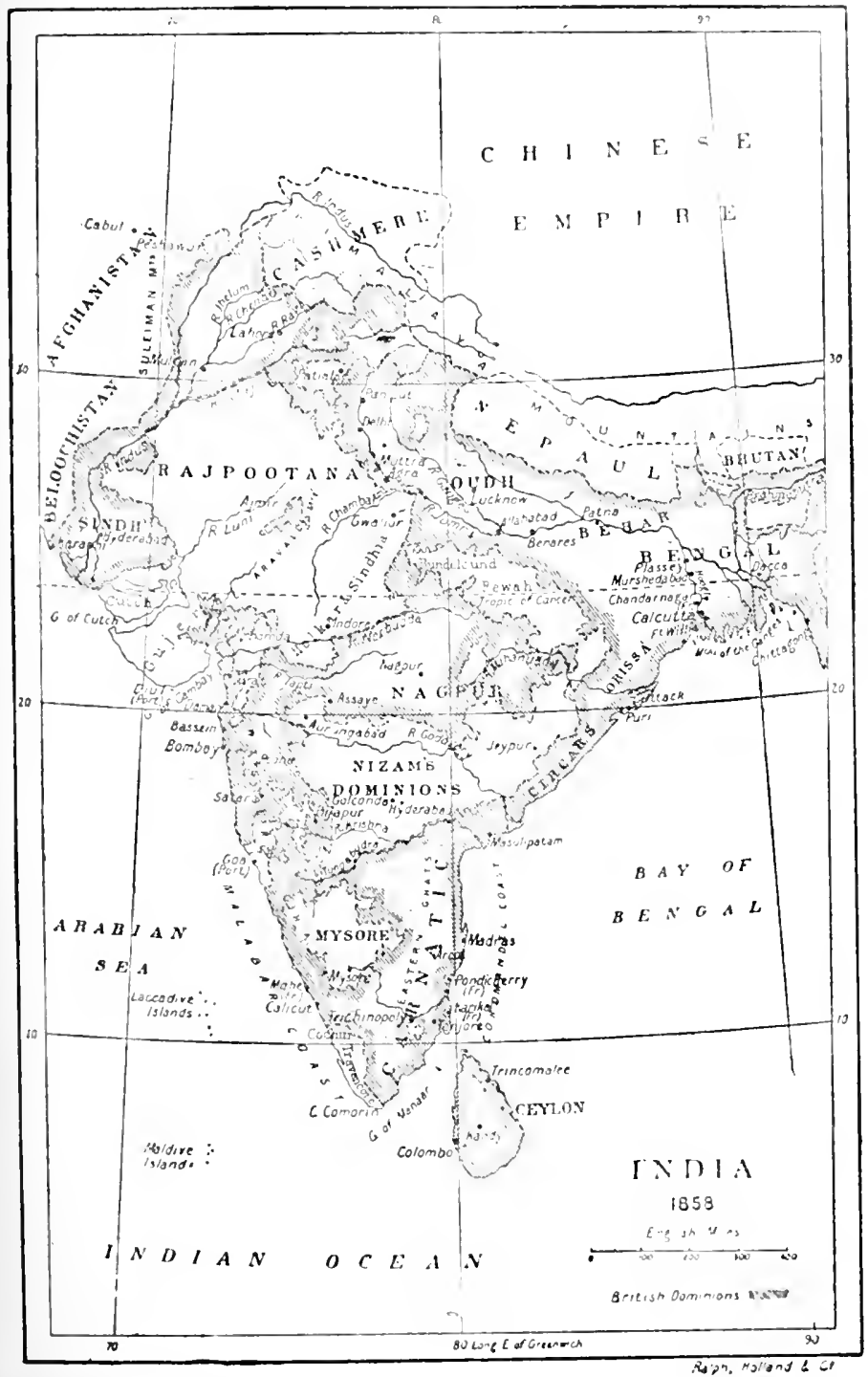


The Siege of Delhi.-The siege of Delhi was hardly a siege in the ordinary sense of the word. Eight thousand British troops camped on a ridge outside the city could hardly be said to besiege a rebel force of thirty thousand men within. About the middle of August there came a considerable re-inforcement from the Punjab, and a month later, on September 14th, it was determined to attempt to capture the city by assault. The attack was successful, the walls stormed, and the gates blown down. Six days' street to street and house to house fighting placed Delhi once more in English hands, but at a cost of 66 officers and 1,100 men. With the capture of Delhi, the interest of the mutiny largely died out. Fighting went on for some eighteen months longer in various parts of the conntry, chiefly in Oudh, which indeed was the only part of India where the rising assumed the character of a general revolt rather than a mutiny among the troops. Here the campaign was carried on by Sir Colin Campbell, while Sir Hugh Rose conducted that in Central India.

The Mutiny sealed the fate of the East India Company, which had ruled the affairs of the country during a career of two and a half centuries. The "Act for the better government of India," which passed the British Parliament in 1858, after acrimonious discussion in the House, and strong opposition from the directors, enacted that India should be governed by and in the name of the Queen of England, that the Governor. general should henceforth bear the title of Viceroy, and that the troops of the Company should be amalgamated with those of the royal service, and the Indian navy be abolished.

The first of the Viceroys was Lord Canning, to whose lot it fell both to suppress the mutiny and to inaugurate the series of peaceful reforms, which have done so much to secure the peace and prosperity of India during the period in which it has been under the control of the British Crown.

Peace was proclaimed throughout India on July 8th, 1859. 


\section{SECTION II.-SINCE 1858.}

After the Mutiny.-Canning had been made Governor General in 1856. After the abolition of the Company, the Governor General received the title of Viceroy. To Canning, as has been said, it fell to quiet India aft the Mutiny. INe did so with such mildness and forbearanee that his crities gave him the name of "Clemency Canning."

At a grand darbar held at Allahabad, 1 st Norember, 185s, a royal proelamation was issued that the Queen hal assumed the government of India; and an ammesty was granted to all except those who had actually murdered British subjects during the Mutiny.

The Mutiny raised the Indian debt by $£ 40,000,000$, to deal with which deficit and to reorganise the Indian finanees generally, Mr. James Wilson was appointed Finance Minister, and a paper curreney was established. In these transformation scenes hitches were bound to occur. There was something like a mutiny amongst the British officers on aceount of their transfer from the service of the Company to that of the Crown without any bounty being given. But the rub was smoothed over. In 1861, the order of the "Star of India" was instituted. The Penal Code and the Courts of Justice were reformed, and many progressive steps taken, especially in the construction of railways, canals, macadamised roads, and lines of telegritph.

In 1860-1861, there was a terrible famine in the Punjab, owing to the failure of the monsoons, and the mortality amounted to about 500,000 persons. The Lonclon Mansion House subscription totalled about $£ 115,000$.

Under Lord Elgin (1862-1863) the "Wahabees" at Patna gare trouble, and had to be repressed. The Wahabees were 
followers of Abd-el-Wahab ("Servant of the Bountiful"), a Muslim reformer, born in Arabia, 1691 (died 1787), who maintained that the Turks and other Mohammedaus had departed widely from the teaching of the Koran.

The cotton industry was being vigorously pushed in India at this time, and the first Indian Agricultural Exhibition was held in Calcutta in 1863.

Under Sir John Lawrence (1864-1868) there were several matters deserving notice. Frontier trouble with the Bhootanese resulted in a little war, in which the latter were defeated at Dhalincote and at Diwangiri. Peace was made, November, 1865. There was another severe famine in Orissa, in which a million-and-a-half persons are said to have perished. After this terrible disaster, irrigation works were undertaken on a larger scale than ever in the Punjab, the North West Provinces, Bengal, Central Provinces, Bombay, Madras, and Mysore, where the chief rivers were linked together by canals, enabling vast tracts of country to be irrigated, which considerably reduced the danger,- - though that danger has even yet by no means passed. These famines, in the expenses they entailed, greatly deranged, from time to time, the financial resources of India, and made India, on several occasions, a source of great anxiety to the mother country. In 1867, there was a deficit of nearly $£ 2,500,000$.

Excited by the Patua rising, the Bazotis, a tribe of fanatical Mohammedans on the North West Frontier, flew to arms, and committed many outrages on British subjects, for which they were punished by General Wilie.

A new land settlement in Oudh and the Punjab, begun by Camning, was finished by Lawrence. The quieting and reorganisation of the North West Provinces, moreover, undertaken by Sir Richard Temple, and prosecuted by him with the most praiseworthy energy, must not be ignored. This process meant a vast amount of varied labour, and included land 
settlements, the organisation of native police and magistrates, the reformation or creation of vernacular schools, dispensaries, vaccination and sanitary measmes, the erection of churches, barracks, court houses, the formation of roals, the builling of traveller's' rests, ctc.

Lord Mayo (1869-1872). The appointment of Lord Mayo, severely criticised at lirst, tumed out a great success, and his period of oftice was one of much moral and material progress for India. To make up for a considerable deficit in the revenue, an income tax was imposed (in the faee, however, of great opposition), and was allowed to remain in force until 1873. The Calcutta and Bombay lixilway wis completed in 1870, and in the following year a civil engrineering college for India was opened at Cooper's Hill on the banks of the Thames.

Expeditions against the refractory Looshais in 1871, and against the Kukas in 1872, were but the prelude to more serious trouble with the Afghans. Our relations with those people were always of a dificult and delicate character, owin: to the fact that in a sense the Amir held the key to the situation. With the great Russian power encroaching on one frontier, and India on the other, he could sile with either as it suited his purpose. England and Russia were both jealous and suspicions of each other, and the Amir knew it, and acted accordingly. The problem was how to treat Af ghanistan. We might conquer the country no cloubt; but that might possibly involve us in a war with Russia, and in any case it would be very difficult to hold Afghanistan, as the natives are intensely hostile to foreign, especially to Christian, rule. Yet it would hardly be politic to allow Russia, who had for many years been creeping on through Central Asia and swillowing up territory in all directions, a free hand in Afghin aftairs. It seemed advisable to get the Amir on our sicle by maling a treaty with him, granting him a pension, and in some way estab- 
lishing a "scientific frontier" on this side. All these difficulties and problems had been fully experienced in the last Afghan War of 1842, when Dost Mohammed had been for a time deposed. Since the death of Dost (in 1865) his three sons had been fighting for the mastery, and their wars had gone on for fire years. Lord Lawrence had pursued towards these brothers a policy of strict non-intervention, or as some called it, "masterly inactivity." When at length, however, the third son, Shere Ali, had suceeded in making himself supreme, the Indian Viceroy determined to recognise the de facto ruler. Lord Mayo therefore held a darbar at Ambala (Umballa) with this object, and invited Shere Ali to be present. Shere came with apparently ambitious expectations of obtaining a large and settled anmuity, and recognition of the sovereignty as cntailed on his younger son to the exclusion of the elder. In these expectations he was not altogether gratified; but he did receive an annuity and valuable presents, and returned, on the whole, as a friendly and well-disposed neighbour. (It was the reversal of this wise policy afterwards by Lord Iytton, under Lord Beaconsfield's ministry, that brought about the terrible Cavagnari tragedy of 1878).

Lord Mayo was a most assiduous worker, and took a great personal interest in his duties. In 1872 , he travelled round his Viceroyalty, and visited Further India. On returning from Raggoon, he took the penal settlement of the Andaman Islands on his way. Landing at Port Blair, he went round the island, not knowing that he was being stallied by a Malay convict whose resentment burned for revenge. The miscreant succeeded in assassinating the Viceroy with a dagger before the latter could regain lis vessel. This tragedy aroused the deepest sorrow and indignation at home, and all parties now joined in recognising Lord Mayo's brilliant and statesmanlike qualities. His remains were taken to Ireland, and accorded a public funeral in Dublin, where the many 
thousands of citizens githered to honour the memory of their countryman.

Lord Northbrook (1872-1876) was destined to see yet another famine, this time in Bengal, and affecting fourteen millions of persons. The Goremment relief works, urganised by Sir Richard Temple, did much to save the situation (1874). The l'rince of Wales's tour through the dependener, in 1875-76, tended to put the people in a good humour, and it forms a lind of landmark in Indian history for the loyalty it awakened. Lord Northbrook's financial ability, and his suceess in coping with the famine must always be remembered to his eredit. MLunieipal institutions were developed consider. ably under his regime, while the staring off of sercral frontier wars must also be placed to his honour. In 1575, Mulkar Rao, the Gaikwar of Baroda, was tried and deposed for misfovern. ment, disloyalty, and attempting to poison Colonel Pinayre.

Lord Lytion (1876-1880). As the result or sequel of the Prince of Wales's visit, Queen Victoria, at a great durbm. at Delhi (January 1st, 1875), was proclimed Empress of India-after previous proclamation in London. A long drought, from 1576 to 1878 , brought about periaps the severest famine that ever visited India. It was worst in the Dekhan and Southern India, where it earried off some five and a quarter millions of people, and eost the Gorermment $£ 11,000,000$.

Restrictions placed on the native press in 1878, and iurther restrictions on the privileges of war correspondents (1879), caused some loud and hostile eritieism. But the chief feature of Lytton's rule was the Afghan imbroglio. Sir Bartle Frere, Sir Henry liawlinson, and others were strongly of opinion that there should be a British resident in Afghanistan, to "tune" the foreign policy of the country and form a comnterpoise to liussian intrigues. Others, however, including Lord Northbrook, linowing low bitterly 
the British "Giaour" was hated by the Muslin Afghan, and how suspicious the latter was of Indian designs on his independence, as strongly discountenanced the "residential" poliey. Lord Northbrook, rather than pursue such a policy, resigned, but the Home Government found in Lord Lytton a viceroy who would obey their behests.

Negotiations were opened with Shere Ali, but that potentate declined all overtures towards receiving a minister, and, on the contrary, welcomed a Russian agent at Kabul. This behariour was treated as an act of war, and a British force was immediately ordered into Afghanistan. Shere Ali fled into Turkestan, and died there. A treaty was then made with his son, Yakub Khan, at Gandamak, by which the British frontier was to be advanced somervhat, and a British officer to be received at Kabul. Yakub was not unfriendly to the English, but he was a mere puppet in the hands of the army, and against the strongly expressed national sentiment he was powerless. Sir Louis Caragnari, with an escort, repaired to Kabul, but within a few months he and his whole escort were nuurdered by the indignant Afghans. The war was at once renewed. Yakub abdicated, or was deposed, and another Afghan chief proclaimed, while the country was put under m intial law. Ayub Khan, Yakub's brother, was decidedly anti-English, and as he was moving about in the neighbourhood of Kandahar, it was deemed prudent to check his advance. In this attempt, however, another disaster befel the English, for General Burrows, with an auxiliary foree of about 2,500 English soldiers, was defeated at Maiwand (near Kandahar) by Ayub, who captured seven British guns (July, 1880). General Roberts then marched south from Kabul, and defeated Ayub (September 1st, 1850) and reliered Kandahas. Abdurrahman, the eldest male of the family, was then proclaimed Amir, and the "residential" policy finally abandoned. 
Under Lord Ripon. who followel Lytton, (1850)-18.t) a period of peace and local developuent ensued, and an Indian contingent went to help the British in the war against Aribi Pasha in Egypt (1892-1884).

some excitement was caused by the trial of MIr. Han. rji, Editor of the Bengali, who was sentenced to imprisomment for libelling Judge Norris, and monster meetings of protest were held by the Hindus.

Under Lord Dufferin (188.1-1583) oeeurted the third Burmese war, in which Upper Burma and the Shan States were annexed. In 1888, outrages upon British troops by the Akozai tribes led to the Black Mountain expedition under General MeQueen, which ended in smatt punishment of and submission by the Akozais. Lady Dufferin interested herself much in Indian aftairs, and raised a large fund to equip female medieal pratitioners.

Under Lord Lansdowne (1899.1893), the Fortress of Quetta was completed, and the frontiers of the Empire further strengthened and made "seientific." A treaty with China provided for more extended British control over Siklim. The Hunga and Nagar tribes, tributaries of Kashmir, who objected to British road-making in their vieinity, were redueed to more immediate British jurisdiction. Trouble from the Chins an 1 Lushais (Burmese frontier tribes), necessitated a punitive expedition, which, under General Symons, however, not only inflicted punishment on those exeeedingly troublesome neighbours, but also opened up and made comparatively securo new commercial highways between India and Burma. The currency, meanwhile, was reformed, and independent mints were closed to the free coinage of silver. The legislative councils were opened to a larger popular clement, and, generally speaking, reform proceeded along democratic lines.

Under Lord Elgin (1894-1898) there were many local troubles caused by famine, plague, earthquake, and frontier fighting. An outbreak among the Chitral tribes, in the extreme northern 
highlands between Kashmir and Afghanistan, neeessitated the sending of a large military foree to put an end to outrages and relieve the British garrison there (1895). In 1896-1897, the outbreaks were renewed, and, extending along the great stretch of frontier as far as Baluchistan, included Pathans, Afridis, Orakzais, and many other tribes, together with the followers of the "Mad Mullah." Sixty thousand troops had to be employed in these hostilities, and the losses amounted to nearly 1,900 men and officers, before quiet was restored. The Afridis were not subdued til! 1898. Further bounlary definitions were arrived at, e.g., between Asiatic Russia and the Pamirs, and with French Territory on the Mekong river. Legislative councils were created for the Punjab and for Burma, and the laws against sedition were modified. Meanwhile, a terrible plague and famine were raging in Bombay, Sindh, Oudh, Punjab, etc. (1896-1897), while an earthquake in Assam caused great disaster.

Lord Curzon's term of office (1899-1905) was a stirring and eventful one, and several new departures took place. The previous consolidations of the Empire seemed to be bearing fruit in the despateh of Indian troops to help the mother country in several foreign wars and eomplications, viz, in South Africa (1899), in China (1900), and in Somaliland (1903-1904). The famine fiend, however, was no means cast out, and it is painful to have to record another terrible famine - one of the worst-in the Punjab, the North West Provinces, Bombay and elsewhere, affecting 450,000 square miles and about $62,000,000$ people, and involving a loss of $\$ 50,000,000$. A kindly element in this calamity was the help that eame from Germany and elsewhere abroad.

There was general grief and mourning in India for the death of Queen Vietoria (January, 1901), and Lord Curzon's proposal for a memorial to her memory in that country was responded to with large and generous donations. 
A great many reforms-edueational, agricultural, financial and commercial-were initiated, and developments encouraged, under Lord Curzon. He also undertook many tours and held several darbars in different places. A new province-the North West Frontier-was created. The Aden and the Per $; 0$ Afghan frontiers were more accurately defined, while from amongst the native prinees and nobles a eorps of Imperial Cadets was formed. From the Nizam a perpetual lease of Berar was secured by a treaty by which the Nizan, in eonsideration of receiving thirty lakks of rupees yearly, gave up all his territorial elains to that country.

In 1902, many native princes and troops attended King Edward's coronation in London, and on the 1st of January, 1903, the same ceremony was celebrated at a great darbar at Delhi, which ancient eity the Viecroy entered in state. accompanied by the Duke and Duehess of Connaught and fifty native prinees. Many honours were distributed on the oceasion, and 16,000 prisoners were released.

In 1903-1904, a new epoch was made in the history of Tibet by the expedition of Colonel Younghusband and General Maedonald. Budthism had been introduced into Tibet in the seventh century, A.s. The Jesuits had risited the country in the seventeenth eentury, but not until recent years had there been any attempts to explore that ancient, strange and very exelusive land. Russians and Germans, as well as Englishmen, had endearoured to traverse and survey the country, but such attempts were jealousiy opposed not only by the Tibetans, but by the Chinese, who claimed a suzerainty over Tibet. For a long time, relations between Great Britain and Tibet had been rery unsatisfactory. The government at Caleutta had been anxious to arrange several outstinding frontier disputes, and to open up traile and commeree with their northern neighbour. In 1886, liritish troops had been obliged to drive Tibetme out of silkim, 
with which a commercial treaty, initiated by Chinese intluence, was concluded. This compact, however, like all others with Tibet, had been evaded or ignored. In 1890 and 1893, similar treaties had been made, and had had a similar fate. As was stated in the House of Commons (April 13th, 1904):"Treaties had been violated, representations disregarded, letters from the Viceroy returned unopened, trade stopped, pillars to mark boundaries overthrown. All this had gone on for fourteen years; it now must cease; but we had no desire to occupy Tibetan territory. Annexation would be a misfortune to India."

At last reparts of Muscovite intrigue were brought to Calcutta, tending to show that Russia was playing the same game here as she had played in Afghanistan. With a continual Russian adrance in Central Asia, and a Russian railway across Siberia from west to east, it seemed equally important to make Tibet a "buffer" state; and Lord Curzon resolved to send a peaceful mission to Tibet. This expedition, under Colonel Younghusband, started, in 1903, to negotiate with the Tibetan chiefs direct. The country is ruled by Buddhist priests, or lamas, the chief of whom, the Dalai Lama, is (like the whilom Mikados of Japan) both the spiritual and temporal ruler of the country. The Tibetans riewed the Indian expedition first with suspicion and alarm, and then with hostility. There was no wish to violate the "sacred capital" of Lhassa, but continual provocation and hostility on the part of the Tibetans caused the expedition to advance to Gyangtse, about 150 miles from Lhassa. In April (1903), that town was occupied by the British troops, ant its fortress, which surrendered without resistance, was dismantled. As the lamas still held aloof, playing a double game, the expedition advanced to Lhassa. The British force was attacked all along the line of march, and several villages hal to be captured and defeats inllicted upon the enemy, 
before General Maelonald could reach his goal. On arriving at Lhassa (Angust 3ro, 1904) the Jritish leader fomml thit the Dalai Lama had tled, leaving, however, his seal to a kind of licgent, with whom negotiations were earriol on. With this liegent a treaty was signed, by which the Tibetiurs arreed to estiblish markets at Gyangtse and Garlok as well as at Yatung, for British trade, and ofli inls of both eountries were to be stationed at those places. P'rovision was also made for the promotion an 1 protection of trade and trafic along existing routes, and others that might be opened up. The Tibetans, moreover, agreed to pay an indemnity of $7,000,000$ rupees $(\{0,10,000)$; and as security for this and the other terms of the treaty, the British troops were to occupy the Chumba Valley for three years. The forts letween Gyangtse and the Indian Frontier were to be demolished. and the Tibetan authorities were not to alienate any portion of their country to a foreign power without the consent of Great Britain. (The indemnity was aiterwards reduced to $£ 166,000$.)

The other events of Lord Curzon's rule ineluded a terrible earthquake in north-western India (1905) involving immense loss of life and property both to natives and Europeans in Jhamsala, Lahore, Amritsar, Kangra, and other distriets. Fiteen thousand persons lost their lives, and Laly ('urzon had a narrow eseape at Simla. The plague supervened in the same year, and caused far greater mortality, 57,000 deaths being reported in one week.

Bengal having become too unwieldy for single management, it was resolved to divide it into two for administrative purposes. This was aecordingly done, the eastern portion of Bengal being united to Assam; but the change was not fully effected until Lord Minto's reyime.

Important army reforms were meanwhile being carried out in conjunction with Lorel Litchener, the Commander-in-Chief, 
but differences between the two chiefs caused Lord Curzon to resign (August, 1905).*

Lord Minto (1905. ) succeeded Lord Curzov. In 19051906, the Prince and Princess of Wales made a tour through India, but the ethical value of the tour was not greatly apparent. The Hindu mind had been greatly stirred by the partition of Bengal, and monster meetings were held, at which resolutions to boycott British goods were passed. The unrest extended to the Punjab, and, in 1907, it was found necessary to pass an act against seditious gatherings. Lord Norley, in his Budget speech of this year, foreshadowed important reforms in the Indian administration, including the appoint. ment of native members to his own council, the extension of the native element in the vice-regal and provincial legislative councils, and the formation of imperial and provincial advisory councils of notables. Decentralisation was to be the key to these changes, which werc, therefore, thoroughly democratic in their character. The Indian Councils Act of 1909 enlarges the vice-regal and legislative councils, and extends the elective element, and generally proceeds on democratic lines.

\section{INDIAN UNREST.}

The results of British rule in India have not, on the whole, been very encouraging, at least not brilliantly satisfactory. With droughts, pestilences and famines, of more or less regular recurrence (five great famines occurred within 40 years); with $40,000,000$ or $50,000,000$ of people insuficiently fed in the intervals; with the military expenditure, and with it taxation, steadily rising-and that without any internal wars in the country itself-it is not to be wondered at that there has been

* Lord Kitchener demanded the abolition of the divided military control, which made in time of war the military member of the council virtually omnipotent in military matters, while Lord Curzon feared that the change would result in a dangerons military dictatorship. The Home Government, however, upheld Lord Kitchener. 
considerable discontent amongst the natires. But other mul more importint causes have combined to sharpen that discontent. Some of those eauses are politieal, some social, and some religious, and in investigating these we can trace a remarkable parallel between India and Ireland.

Religious Causes. - In both Indiia aud Ireland there are two religious communions, each violently opposed to the other, IInduism and Islam (or Mohammedanism) in the former: and Roman Catholicism and Protestantism in the latter country. In both countries the older ereed has a deeided majority-Hinduism in India, and Roman Catholicism in Ireland. In both countries the religrious antagonism has led to political hostility. In both countries the dominant ereed favours "Home Rule." The Hindu: demand "India for the Inlians," as the Irish Roman Catholies demand "Ireland for the Irish." In both countries the minority objects to Home liule, and for similar reasons. The Mohammedans fear that the withdrawal of the English would leave them to the merey of the Ifindus, to be oppressed, if not exterminated, by a code of anti-Islam laws; and the Irish Protestints fear for their own future at the hands of the Nationalists uncler Home Rule, and (as they complain) they are already being systematically boycotted and tyrannised over by the County and Borough Councils with every extension of local self. government.

Industrial Causes. - The industrial classes of India used to do very good hand-work, especially in weaving, dyeing, metal and leather work, for which they hal good marliets, and received good pay. But with the rast exten-ion of ste:m and machinery, the loom-owners of England have been demanding more and more of the raw (i.c., chenp) material, and British firms less and less of the manufactured (i.e.. the well-paid) artiele. 
"In the early days of the Company's rule, fabrics produced by Indian weavers supplied the markets of Europe, and men still living can remember the days when every village in the weaving district had its looms, and millions of Indian weavers were supported by that profitable industry. How this industry was gradually strangled and destroyed, first by protective duties imposed on Indian goods in England, and then by an unequal competition; how Indian weavers, who were content with threepence or fourpence a day, found themselves ruined by the cheaper products of English looms; and how the weaver communities of India were compelled to abandon their trade, and to depend on agriculture or petty trade, or on humble and ill-paid appointments in public and private offices-all this forms one of the saddest chapters in the history of British India. What happened to the weavers has also happened to the other industrial classes. The production of the lac dyes has died out since the importation of aniline dyes; and Indian workers in metals and in leather can scarcely hold their own against imported goods. Millions of artisans have been ousted from their occupations, and have taken to agriculture, and the pressure on the resources of the soil has thus increased with the decadence of our industries. We have ourselves seen, and all Indian administrators who have spent years of their life in the old weaving districts have seen, that the old villages of weavers are often overgrown with jungle, temples constructed by those classes are in decay, large irrigation tanks excavated by them are silted up, and have not been re-dug or replaced by other tanks. The villages know not their artisan population who flourished there of old; they have dispersed all over the country as agriculturists, or have crowded to towns as petty traders. 'Leave off wearing; supply us with the raw material, and we will wcave for you,' was virtually what the East India Company said to the Indian weaver at the 
beginning of the eentury, and this mandate has been only too serupulously and cruelly followed." *

Social Causes.-The normal state of poverty in which a very large number of the native population live, is traced by many of the native agitators and journalists to the periodieal valuations of land. In only one provinee of India are the land rents permanently fixed by law, and therefore unalterable, viz., in Bengal. In other parts fresh valuations are made every thirty, twenty, and sometimes even fifteen years, so that the unearned inerement may go partly to the landlord (i.e., the Government), and not altogether to the tenant. Bengal (it is elaimed) has on this account always been more prosperous than other parts of Indii, and therefore that the prineiple of permanency of rents should be applied to the rest of India.

International Causes.-But perhaps the most potent cause of all in producing the present "national " movement in Inlia is the phenomenal rise of Japan. In Japan, the East has seen a small, weak and obscure eommunity of islanders rise suddenly into-not only a great eastern, but a great world. power, and after prosecuting two great and successful wars, spread her products and manufactures over a great part of the civilised world. What Japan, with a perfeetly free hand has done, why might not India, with a similarly free hand, do?

Conclusion.-It must not be inferred from the foregoing paragraphs that British rule in India has been a failure. The agitators are loud and eonspicuous, but they are a small minority, and when we eome to scrutinise what England has really dono for India, we may, without self-complacency, pronounee it a magnifieent achievement. Droughts are still frequent-as they must always have been-beeauso, depending on the monsoons, they are beyond the control of man; but

- England and India, by Romesh C. Dutt, pp, 127-129. 
the irrigation works, and the complex and elaborate organisation to cope with famines and relieve distress, are nothing short of marvellous; and the loss of life becomes less and less every time. Add to this the medical and sanitary systems established, and the hospitals erected, the courts of law and justice, and the native police which have been instituted, the development of railways, the spread of education, and the foundation of schools, colleges and universities, the harbours, roads, bridges, and public buildings which adorn the municipal centres; the care of the aborigines, lepers and other outcasts, and all the other beneficent work accomplished by the missionaries; the abolition of the sati, the suppression of infanticide and of the thugs; the raising of the status of women; when we remember these things, and, lastly, when we recall the incessant civil wars, broils, conspiracies, and murders, which were a chronic characteristic of Indian life before the country came under British rule, and which would infallibly revive were British rule withdrawn, we may fairly congratulate British statesmanship on the monument she has raised to health, wealth, peace and progress in India. 


\title{
CHRONOLOGICAL TABLE
}

\author{
ILLUSTRATING
}

\section{The Growth of British Rule in India.}

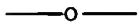

1602. East India Company Incorporated.

1612. First Settlement founded at Surat.

1639. Fort 8t. George founded.

1640. Factory founded at Hughli.

16:5. Bombay becomes the Company's healquarters on thr Malabar Coast.

1693. Founding of l'ort IVilliam and Caleutta.

1707. Death of Aurungzeb, the Great Mughal.

1774. War declited beliceen Englad and Frince.

1746. Malras captured by Labourdonnais.

1746. Battle of St. Thome. The Nawib of the Karnatik (Anwiru'din) attacks Madras and is easily defeated by the French under Dupleix.

Treaty of Alx-la-Chapelle, 1748. (All conque-1s restured.)

1749. The Secund Anglo-French Slruggle. Cause:-The ambitious schemes of Dupleix, who desired to found a French Empire in India.

1750. Siege of Triehinopoly. Mubammed All holds tho city against Chanda Sáhib aided by the French.

1751. Siege of Arcot. Clive defends Arcot against Rajá Sáhib.

1752-1. Siege of Triehinopoly (Second). The British defend Trichinopoly against the Nizam of the Dekban and his French allies.

1756. The Seven Years' War c"mmenees.

1758. The Black Hole of Calcutta.

1757. Battle of Plassey. THE FOUNDATION OF BRITISIT RULE IN INDIA.

1760. Battle of Wandewash. Sir Eyre Coote defeats the Comte de Lally and gains the control of the Karnatik.

1761. Capture of Pondieherry.

1763. Massacre of Patní.

1764. Battle of Baxár. British victory. Oudh contpuered.

1765. Treaty of Allahábiat.

1767.9. War with Haidar Alk.

1773. The Regulating Act.

1774. The First Rohilla War.

1778. First Marathi War. (Ended with the Treaty of Salhal, 1782.) 
1730. Haidar Alf invades the Karnatik. (Second war with Haidar Alf 1780-3.)

1781. Battles of Porto Novo and Pollilore. British victories.

Treaty of Yersailles, 1783.

\section{Pitt's India Bill.}

1790. Third Mysore War (with Tipú, son of Haidar Alí).

1798. Marquis of Wellesley, Governor-General. The Subsidiary System.

1799. Capture of Seringapatam.

1802. Treaty of Bassein. The Marithá Confederation brokeu.

1803. Battle of Assaye. (Second Marithá War-with Sindhia).

1813. The East 1ndia Company loses the Monopoly of Indian Trade.

1814. War with the Gurkhas.

1817. Third Maráthá War.

Capture of Raugoon.

1825. Cession of Assam.

1826. Cession of Arakan and Tenasserim by the King of Aya.

1830. Mysore becomes a Protectorate.

1838. First Afghan War.

1839. Capture of Kabul and Kandahar.

1811. Disastrous British retreat through the Khyber Pass.

1843. Annexation of Sindh.

1845. The First Sikh War. British victories at Ferozshah and Mudki.

1916. " " " British victories at Aliwal and Sobráon.

Dhulep Singh made Maharajah of the Punjab.

1818. Second Sikh War. British victories at MIuItan, Chilianwálla and Guzerat.

1849. Annexation of the Punjab.

1852. Annexation of Pegu.

1853. Cession of Berar.

1856. Annexation of Oudh.

1857. The Indian Mutiny. The Sepoys alone mutinied, the Sikhs remaining loyal.

1858. East India Company abolished.

1859. The Punjab made a Presidency.

1864. Bhootan War.

1875. Deposition of the Gaikwar of Baroda.

1877. Royal Titles Act-Queen Yictoria proclaimed Empress of India.

1873. Second Afghan War.

"Scientifle" definition of Indo-Afghan frontier.

1879. Treaty of Gandamak (Afghan).

1892. Indian troops serve in Egypt.

1885-6. Thira Burmese War-Annexation of Upper Burma and the Shan States.

1837. Annexation of Quetta and other parts of Beluchistan. 
1898. Black Mountain Expedition (General MeQtuen.

1890. Treaty witl Chinn $r^{\prime}$ 'sikkim.

Manipur Rising. Lushai Expedition.

1891. Black Mountain Expedition (General Willes).

Miranai Valley Expedition (General Loekhart.

1895. Chitral Expedition (Colonel Kelly).

1897-8. "Mullah" War; Afridi rising. Tital Campairn; Dargai and Chałn actions.

1899. Indian troops serve in South Africa.

1900. Indian troops serve in China.

1901. North-West Frontier Province formed out of portion of Punjab.

1902. Perpetual lease of Berar obtained-the Nizam renounces claims an ? receives a pension.

1902. Coronation Darbar of King Edward VII.

1903.4. Tibet Expedition.

1903-4. Indian troops serve in Somaliland.

1:105. Indo-Japanese Commercial Treaty.

1905. Formation of Province of Eastern Bengal and Assam.

1905. Renewal of Afghan Treaty.

1909. Indian Councils Act-increasing personal powers of Legislativo Councils and enlarglng elective element. Came in to force, January, 1910.

GOVERNORS-GENERAL OF 1NDIA.

\begin{tabular}{|c|c|c|c|c|c|c|c|}
\hline Warren Hastings... & $\ldots$ & ... & 1771 & Lord Dalhousie & $\cdots$ & $\cdots$ & ... I 1213 \\
\hline Lord Cornwallis ... & $\ldots$ & $\ldots$ & 1786 & Lord Canning & $\ldots$ & $\ldots$ & ... 1935 \\
\hline Bir John Shore $\quad .$. & ... & ... & 1793 & first & t vic & nor & $\ldots(18,5)$ \\
\hline Marquis Wellesley & ... & $\cdots$ & 1793 & Lord Elgin ... & $\cdots$ & $\ldots$ & $\ldots \quad 1-6 i 2$ \\
\hline Lord Cornwallis ... & $\ldots$ & $\ldots$ & 1805 & Sir Jolin Lawrenc & & $\cdots$ & $\ldots 1\{i j \mid$ \\
\hline Bir George Barlow & $\ldots$ & $\ldots$ & 1805 & Lord Mayo ... & ... & $\ldots$ & $\ldots \quad 158,9$ \\
\hline Lord MIinto & $\ldots$ & $\cdots$ & 1807 & Lord Northbrouk & $\ldots$ & $\ldots$ & $\ldots \quad 1272$ \\
\hline Lord Moira (Marquiso & Has & ngs) & 1813 & Lord Lytton & ... & $\cdots$ & $\ldots \quad 1-70$ \\
\hline Lord Amherst & $\ldots$ & $\cdots$ & 1823 & Lord Ripon & $\cdots$ & $\ldots$ & $\ldots \quad 1 \times 3\}$ \\
\hline Lord Wm. Bentinck & $\cdots$ & .. & 1528 & Lord Dufferin & $\cdots$ & $\cdots$ & $\ldots 1 \times 81$ \\
\hline Bir Charles Metcalfe & $\cdots$ & $\cdots$ & 1835 & Lord Lansdowne & $\cdots$ & $\ldots$ & ... 1niag \\
\hline Lord Auckland $\ldots$ & $\cdots$ & $\cdots$ & 1836 & Lord Elgin & $\cdots$ & $\ldots$ & ... 1 - 214 \\
\hline Lord Ellenborouglı & ... & $\ldots$ & 1512 & I.ord Curzon & $\ldots$ & $\cdots$ & $\ldots 1-1,1$ \\
\hline Bir Henry Hardinge & $\ldots$ & $\ldots$ & 1811 & Isord Mlinto & $\ldots$ & $\ldots$ & .. 190 \\
\hline
\end{tabular}


CHAPTER IV.

\section{- 0 - \\ The British in America.

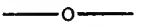 \\ SECTION I.-BEFORE 1858.}

Early Attempta at Colonisation.-The history of the English in America begins with the memorable expedition sent out in 1497, by King Henry VII., in which John Cabot, sailing due west, reached that part of Labrador, which he termed New. found-land, together with the island known by that name, whose barren and rocky shores formed a poor substitute for that fabled region of Cathay, which he had set out to find. If the riches be had desired were not to be obtained, wealth of another sort was not wanting, and the Bristol seamen, who had followed Cabot, were quick to take advantage of the limitless supply of fish yielded by the great sand banks, now discovered for the first time. Eighty years later, the Bristol fishing fleet to the banks had grown to fifty sail, and the prosperity of the city had vastly increased in consequence. The first attempt at colonisation was made by Sir Humphry Gilbert in 1583, who sailed for St. John's with four ships. When, however, the colonists saw the bleak and barren region to which they had come, their hearts failed, they became motinous and forced their leader to re-embark for England. On the vay back occurred a great storm, and Sir Humphry, 
with all his ship's crew was drowned. His project perished with him. His famous half-brother-Sir Walter Raleigh-fared no better. In 1584, he, with a charter from Queen Elizabstl, organised expeditions to the state be had named Virginin in honour of the Virgin Queen, hoping to build up there nnother England. Disaster dogged his steps, and each expedition seemed more unfortunate than its predecessor. The attempt of the settlers to obtain land from the natives provoked such savage reprisals that scarce a man returned to England. Thus the reign of Elizabeth, glorious as it was, by reason of that great movement of expansion which it inangurated, saw but little of its ellects. The age was one of contlict, and the men, who, in a time of peace, would have become the leaders of colonisation, were employed in repelling the attacks of their country's enemies, or in preying upon their commerce. But the work they did in exploring, and in bringing before men's eyes the wealth that was to be gained beyond seas liad a value all its own and bore ample fruit in the period of peace which followed the defeat of the Spanish Armada. England, like other countries, habitually bargained away the commercial rights she had gained in war to private adventurers, or to companies, who thus acquired the inonopoly of a given trade. Hence there arose numbers of traling companies, willing to adventure considerable sums of money in enterprises to distant lands. The work attempted with such disastrous results by Raleigh was continued by two great corporations, the l'lynouth Adventurers and the South Virginia Company, and in Lito6, a little settlement was made at Jumestown, the first of our American colonies. Captain Smith, its founder, instead of attempting, by force, to wring concessions from the Indians adopted the plan of attempting to conciliate them. The story of his American bride Pocahontas, the "belle sauvage," is on of the most familiar as well as the most pleasing in the romance of history. 
In 1620, occurred the famous voyage of the Mayflower, which carried the Pilgrim Fathers from religious persecution at home, to found in New England a state where they might worship according to the dictates of their conscience. Three years later, Nova Scotia and Prince Edward Island were settled.

In 1636, the Catholics, under Lord Baltimore, sought relief from the pressure of the recusancy laws, by founding the colony of Maryland, as their Puritan fellow countrymen of the Manflower had founded the New England states of Massachu. setts and New Plymouth. To the latter, there came a steady stream of Puritan emigration until by 1643 there were four goodly groups of colonies, Rhode Island, Massachusetts, Connecticut and New Hampshire, which organised themselves as the United Colonies of New England.

Then followed Georgia, the outcome of the philanthropic Oglethorpe's efforts on behalf of insolvent debtors, who, doomed to imprisonment at home, might, he thought, here become useful citizens and loyal subjects of King George. The North and South Carolinas were granted by the first Charles in payment of a debt to Robert Heath, and transferred by him to the Earl of Arundel, who colonised them in 1660 , calling them the Carolinas in compliment to King Charles II., who had confirmed his father's grant. Lastly came New York and New Jersey, both of which were originally settled by the Dutch and captured from them during the Dutch war of 1664. The settied areas, however, as yet comprised the merest fringe on the Atlantic coast, hedged in by the Alleghanies, beyond which lay the Indian villages and the French settlements along the Mirsissippi. 
Britain and her American Colonies. - Uniler the oll system of colonisation, Britain treated ber colonies as existin: mercly for the benefit of the mother country. All other nations were excluded from their trade in the hope of fosterin: the home industries. Spain had been the first of the great European countries to adopt this policy, and her exnmple had been quickly followed by Flolland and the other colonising nations of the Continent. Britain had been the last to adopt the practicc. Until the time of the Protectoratc, trade with the Americas had been perfectly free. The charters granted to the early settlers had clearly permitted them to tride with other countries, and as early as 1620 the tolacco planters of Virginia had their warehouses in Middleburg and Flushing and did a lucrative and increasing trade with Hollind. But the Navigation Lawg changed all this. The first of these, passed in 1651 , secured to Britain the carring trade with the American colonies and forbade the importation of Europenn commodities save in English bottoms, while the third, passed In 1673, made the exportation of colonial produce, save to England, illegal. The rigorous enforcement of these laws would have ruined the trade of the colonies, and it is to be feared that they were honoured rather in the breach than in the observance. As a consequence, a vast illicit trade sprang up, chiefly with the Spanish and the French West Indies, a trade which the home gorernment in vain attemyted to check.

In the end public opinion became strongly lieated on both sides, and relations between the mother country and her American offshoots grew more and more strained. The Treaty of Utrecht recognised the evil by sanctioning trade between the American colonies and those of the Spanish und French colonieg "where hitherto trale and inumerce hud been accustomed"; a proviso significant of the fact that the British government recognised both the evil which lund prevailed and the difliculty of dealing with it without extrene 


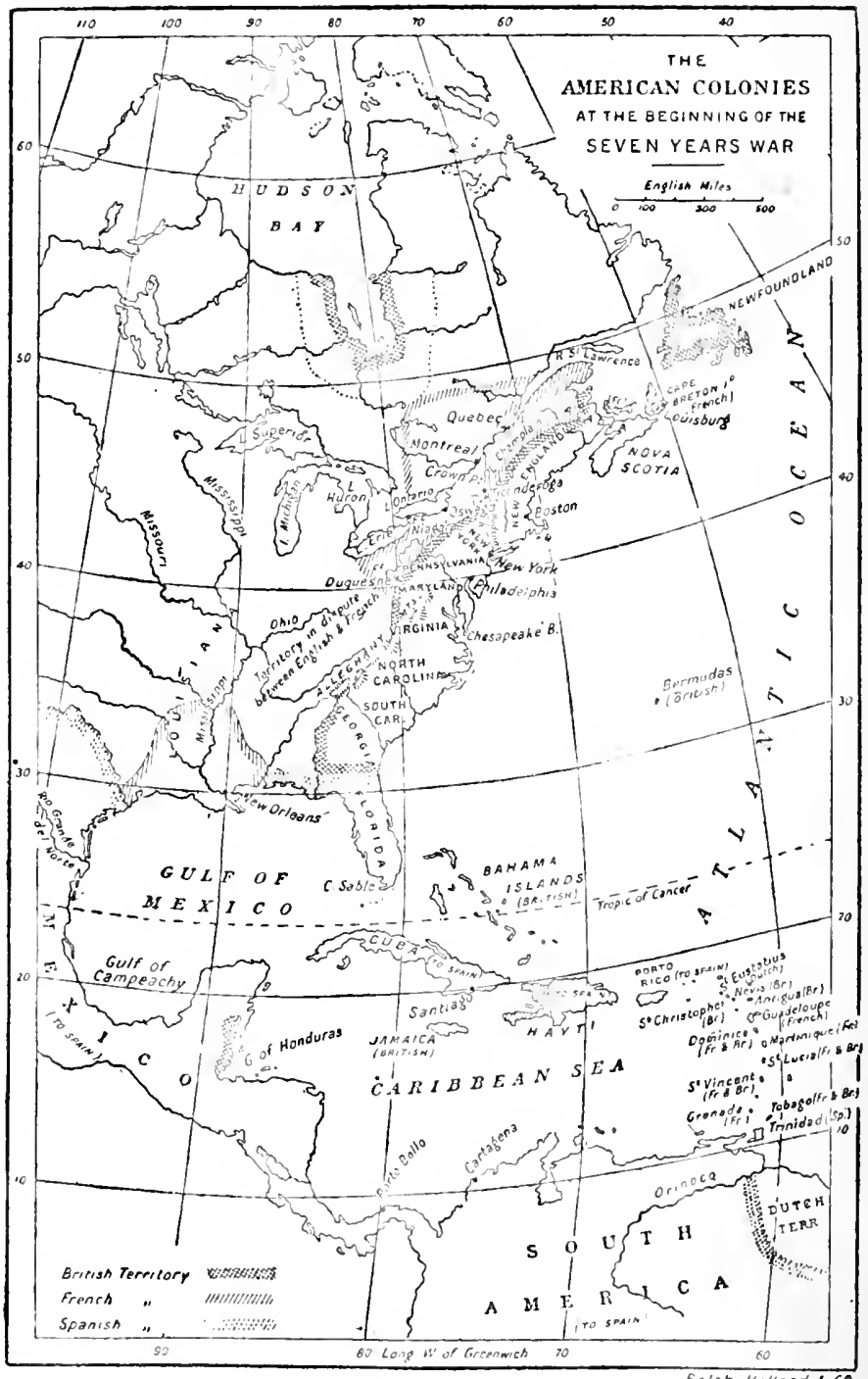


measures, which they were loth to adopt. Even now, the growth of manufactures in the colonies was distinctly dis. couraged upon the ground that it interfered with British industries and tended to lessen the dependence of the colonies upon Britain. The colonists claimed, with justice, that the bome government attempted to cripule their trade and prevent their advancement, while the English statesmen, who took the opposite view, protested that they were quite within their rights and that as the colonists had lourished under the protection of the mother country, it was but just that the latter should receive all the adrantage possible from the connection. Tempers rose high on both sides the Atlantic. Matters were in this state when the illness of the great Earl of Chatham left the control of affairs in the hands of his able but erratic and headstrong lieutenant, Charles Townshend. The latter determined, with the sanction of the King, to make the colonists pay for the expense to which the country had been put in their defence, by the imposition of new customs duties and the rigorous exaction of the old. The Navigation Acts, hitherto practically a dead letter in the West Indian seas, were, henceforth, to be strictly enforced; British cruisers picheted the seas, and Custom house oflicers, armed with "writs of assistance"-obnoxious warrants, in which no person was named-entered private houses at will in the search for smuggled or excisable goods.

As a result of these "writs of assiatance," publie opinion bernine greatly beated and $n$ contict arose exactly sinilar to tha between the government and John Wilkes at home, and on the satue subject -the legality of genernl warrants.

Townshend's successor-Grenville-went a step further. Not only did he require the colonies to assist in paring for their own defence, bat they must now also help to defray the cost of the defence of the empire. Since the war which 
had juat been concluded had been undertaken in the defence of the colonies, it seemed reasonable from

The Stamp Act, 1765.

an English point of view that the colonies should aid in bearing the cost. The means saggested-a tax on all stamped documents-seemed, again from an English standpoint, equally unobjectionable. The colonies thought otherwise. They were willing to vote, each in its own Assembly, a sum of money to assist the old country at this juncture, but they denied the country's right to tax them while they were unrepresented in its Parliament.

In vain did British statesmen point out that the majority of English boroughs were as little represented as they. The colonists retorted that there was all the more need for reform. The colonial Houses of Assembly carried resolution after resolution denying the right of the British Parliament to levy the imposition, and colonial feeling went with its representatives. Public meetings were held, the agitation grew till it attained the proportions of a tumult, riots broke out in various parts of the country, effigies of Lord Bute, the King's adviser and confidant, and of Oliver-the official "Stamp. master"-were burned, and a band of young men calling themselves "Patriots" broke into the Boston stamp-office, destroyed all the stamped documents it contained, and burnt it to the ground.

From the agitation thus raised, grew the idea among the leaders of colonial opinion that their future welfare lay in the direction of independence. Henceforth they were constantly on the qui vive for some cause of complaint which they could make the ground of a breach with the home government. The Stamp Act, which had been the cause of all the tumult, was repealed in the following year (1766). but its repeal was foolishly accompanied by a Declara. tory Act insisting on the right of the British Parliament to levy what taxes they pleased in the colonies. Thus whilo 
in securing the repeal of the obnoxious act, the colonial agitators felt that they had scomed a victory over the home government; the real point at issue-the right of the British parliament to tax the colonies-was still in abeyance, and might, should occasion arise, cause a renewal of all the trouble. The occasion was not long in coming. The colonists had, whilst resisting the excise, acknowledged their liability to pay custons duties. The year following the repeal of the Stamp Act, saw the imposition of a customs duty on tea, glass, painters' colours, paper and other small articles. It was understrod that the whole of the proceeds should be devoted to the defence of the colonies. But the iden of independence, conceived during the former agitation, had now taken deep root. The agitation revived but with a difference. Formerly the right of Britain to impose internal duties had alune been contested, now its right to levy taxes of any description was denied. Lord North, then in power, repealed all save the trix on tea. This he retained " on principle." But the question was 8 question of principle and of principle alone. By arrange. ments made with the East India Company, the colonists would have been enabled to get their tea actually chenper than before, if they would but consent to pay the small

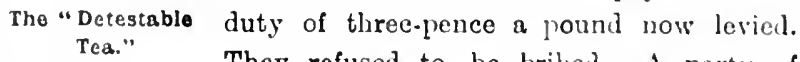

They refused to be bribed. A party of youtha, disguised as Red Indians, boarded the first ship which entered Boston harbour laden with the "detestable tea," and threw her cargo into the water. At other ports its reception, if less violent, was no less decisive. The King, already annoyed at the "fatal compliance" which led to tho withdrareal of the Stanp Act in 1766, was now exultant. The colonists were rebels and he would crush them as such. Troops were deapatched from Europe, and all persons impli. cated in the recent disturbances ortercil to be brought to rngland for trial. "The colonists," decirlal the King, "must 
either triurnph or submit." He certainly had no fear of the result. "They will only be lions while we are lambs," he sapiently concluded, "if we take the resolute part they will undoubtedly be very meek." There was little sign of meekness about the proceedings of the rebellious colonies. "At a time when our lordly masters in Great Britain will be satisfied with nothing less than the deprivation of American freedom," wrote George Washington, " no man should scruple or hesitate a moment to use arms in defence of so great a blessing."

The spirit was general throughout the colonies. A congress was called, including delegates from twelve colonies, and a Declaration of Rights of Americe drawn up. Both sides now prepared for war. The first outbreak occurred at Lexington in 1775 , when a party of British troops-sent to destroy a store of arms and ammunition which the rebels had collected at Concord-were attacked and utterly routed by the colonial militia. Compelled, without the possibility of retaliation, to run a gauntlet of fire, all order was lost and discipline disappeared in the panic. The retreat became a headlong race for shelter.

Roused by the sight of the regulars in flight before the militia, the colonists flocked to arms. Within a month 20,000 colonial troops had gathered before the British camp in Boston. A body of them entrenched themselves on Bunker Hill, a position which dominated the British camp, and it became necessary to dislodge them. Twice the regulars, advancing to the attack, were repulsed by the steady and deadly fire poured in by the American militia. The third time, stripping off their equipments-a hundred and twenty-five pounds a man was the fashion of the day-they again breasted the storm of shot, reached the hill-top, and swept the Americans before them down the opposite slope. The Battle of Bunker Hill was accepted by the rebels in the light of an omen. It proved that, given the advantage of the ground, their untrained 


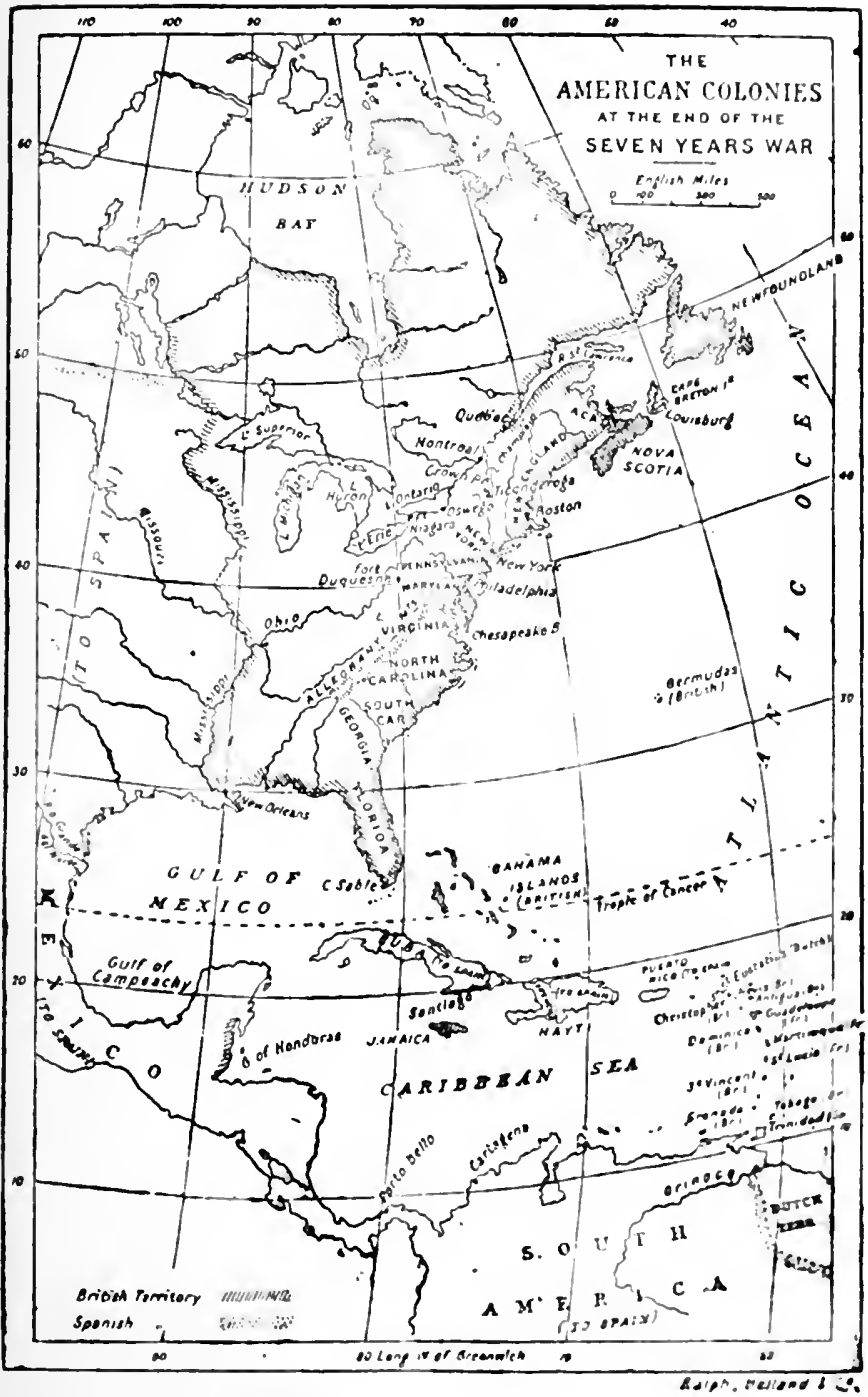


troops might contend on terms approaching equality with the disciplined soldiery sent out by Britain. The course of the war hardly confirmed this view. Throughout each of its campaigns the English were almost uniformly victorious in the field. The disasters to the British arms which cost Britain her American colonies were due to grave faults on the part of her commanders, rather than to any lack of courage on the part of her troops. These events were followed by the Declaration of American Independence in 1776, in which the colonists proclaimed themselves independent of Britain under the title of the United States of America.

The War of American Independence.-The war that followed lasted through about seven years, during which period the position of the colonists was often desperate. The troops wanted for food and clothing, were insufficiently armed, and badly provided with ammunition. Perhaps the worst episode of that time was the winter spent by Washington at Valley Forge, during which his troops died by hundreds from actual starvation, to say nothing of the lives which were lost through exposure to the winter cold. Such a time is an infallible test by which to distinguish the true from the false; and few, to whom it has been applied, have survived the ordeal better than the faithful band which braved, with Washington, the rigours of that terrible winter.

Two great reverses to the British arms brought the war to a close. The first was the surrender of General Burgoyne at Saratoga, in 1777, which determined the French to espouse the American cause and led them to form a treaty with the colonists, recognising their independence, and making common cause with them against Great Britain. The second was the surrender of Lord Cornwallis at Yorktown, in 1781, which convinced the British government of the impossibility of coercing the rebels into obedience; and American Independence was acknowledged by the Treaty of Versailles, 1783. 
The English and French In Amerlea.-Although she had been preceded in America by both Spain and Englund, lintuee had been by no means backward in exploring and settling the continent. In 1534, Jaeques Cartier discovered the St. Law. rence, and, on his return to France, strenuously ured the desirability of colonising the country. In spite of his efforts, however, it remained undisturbed by Europeans for more than fifty years. Two names remain to mark his visit: the naude of the country itself-Canada-which he, hearing the natives speak of their Kanatha, or villages, mistook for the name of the country; and Montreal, which he dubbed Mont Royal. The country was, however, generally known as New France.

In the year 1598 a party of conviets attempted to eficet a permanent settlement in the country. The attempt failed after five yeurs of terrible privation. One or two other efforts were made but without avail, until, in 1603 , the celebrated Samnel Champlitin explored the St. Lawrence, and in the next year returned witl a small colonising party. "All New France." quaintly remarks an old chronicler, "was contained in two small vesscls." The first settlement was made in Nova Scotia, and thence exploring parties were sent throughout the country with the view of determining the best site for a station. After four years of scureh, the choice fell npon Quebec, and Champlain, returning to France for stores, bromght back with him two ship loads of new colonists. His eareful rule gradually overcame all the difficulties which hampered the new eolony, and the little scttlement appeared upon the high road to success. Religious dilliculties, however, came to check its progress. The early settlers had been largely Huguenots. In 1627, the manage. ment of the colony was entrusted to the Catholic Association of the Hundred Partners, through which the great Cardinal de Richelieu attempted to secure, in the first place, the con. version of the North American Indians to Christianity ; and, in the second, to extend the commercial interests of France 
and, in particular, to develop the fur trade. The early settlers now found themselves at variance with the authorities, and the governor, Champlain, was compelled to reorganise his colony in accordance with the new conditions. Hence there arose considerable embarrassment, and the development of the colony was for a time slow. Greater embarrassment, however, was soon to arise. The English, who had hitherto confined their attention to the prosecution of the Newfoundland fisheries, saw with the greatest jealousy the encroachments of the French on a territory which they, in virtue of Cabot's discovery, had been wont to consider their own. In 1614, a force was sent from the Virginia Company's settlement at Jamestown against the little French colony at Port Royal in Nova Scotia, which it captured and annexed to the British territories. Nothing more was done at the time, but, in 1621, James I. made a royal grant of the whole of the peninsula to Sir William Alexander, who immediately proceeded to colonise it with Scotsmen.

The colony now for the first time received its name-Nova Scotia-and, four years later, Charles I. created a distinct order of baronets, each of whom, in addition to his knighthood, received a grant of sixteen thousand acres

Noxa Scotia. in the new country on condition of sending at least six men to settle there. Thus augmented, the colonists found themselves sufficiently strong numerically to invade the territories of their French neighbours, and a force under Kirke was despatched against Quebec. Champlain, called upon to surrender, heroically replied that he was sure his adversaries would respect him more for not abandoning his charge without first making trial of the English guns and batteries, and that he would, therefore, await the attack. The attempt was fruitless, but, in the year 1629, the failure of supplies threw Quebec into the hands of the English, who held it for three years, until 1632, when, 
by the Treaty of St. Germains, Quebec and all the territory in dispute, sweeping from Cape Breton to the extreme west, was acknowledged to be French and Champlain, "the Father of the Colony," returned to take up its aduinistration once more.

Champlain died in 1635, and the territory he had opened up became the theatre of strife between the French and the English for the next hundred and thirty years. The colonising spirit, once aroused, became active among the French, and their colonies crept further and further towards the interior, and towards the south. With this came also a great develop. ment of the missionary spirit and Franciscans and Jesuits vied with each other in risking their lives to carry the gospel among the Indian tribes. These planted settlements along the lincs of the great lakes, crept southward through Michigan, Ohio, Wisconsin and Illinois until in 1673, they reached the Mississippi, and floated down the great river in their canoes to a point below the junction of the Arkansas. Other adrenturers, this time of a more mercenary type, followed their course and tracing the river to its mouth, planted their country's flag on the shores of the Mexican Gulf.

Anong the chicf of these was La Salle, who, in 1682, explored the vast and fertile region which he named Louisiana in honour of the Grand Monarque, and who, sailing with a band of adventurous colonists, was shipwrecked on the const of Texas, of which region, he, prompt to turn misfortune to account, took possession also. By the close of the century France held, in Ameriea, the whole of the const from Hudson's Bay to Maine, the vast and undefined territory known as New France or Acadia, and now as Canada, besides large tracts in the Mississippi valley. Thirteen years later, the treaty of Utrecht saw the cession to Britain of Hudson Bay, Acadia and Newfoundland. France still, however, retained Camada and the settlemer.ts on the Mississippi. Here she more than held 
her own, extending her borders along the Alleghany and the Ohio settling Indiana and founding the new state of Arkansas. As might have been anticipated, the rivalry between the French and the English was intense, and a guerilla warfare, in which both parties sought the aid of the savage Indian tribes was waged over all the neutral ground between their settlements. With the outbreak of the Seven Years' War, the English colonists combincd for a grand attack upon the French. The results were at first hardly of an encouraging kind. A body of troops under Washington was defeated at Fort Duquesne and forced to capitulate, and the whole country west of the Alleghanies fell into the hands of the French. The situation was serious and General Braddock was sent over from England to save it. Courageous to a degree, he had no knowledge of the peculiar tactics of Indian warfare, and it was by means of Indian tactics that the contest was carried on. Braddock was readily entrapped into an ambush at Fort Duquesne in 1755, and utterly defeated with the loss of half his force. He was himself so sererely wounded that he died four days after. In New Brunswick, the English arms were more successful, and in Nova Scotia, the French inhabitants to the number of about 18,000, rising in arms, in the hope of aiding their countrymen to reconquer the province, were forcibly expelled by the English authorities under circumstances of great hardship, for which, however, they or thcir leaders, inust be alone held responsible.

The expulsion of the Aeadians has been pathetically told by Longfellow in his poem "Evangeline," which, if it errs in concealing the offences which brought upon the settlers so terrible a retribution, by no means exaggerates their troubles or their homely worth. After the final transfer of the country to Britsin in 1760 , they were per. mitted to return on condition of acknowledging themselves British subjects, and about a sixth availed themselves of the permission thus accorded. 
The Conquest of Canada.-The defeal of Washington, and, later, of Braddock, at Fort Duquesne drew Englund's nttention to the importance of the conllict, and Pitt, keenly desirous of extending our coloninl empire, formulated a grand seheme for the conquest of Canada. He urgently appealed to the colonists to raise a sufficient body of troops, and PItt's scheme promised to reimburse them for their expendi. of Conquest. ture from the national exchequer, superseded the incapable English commanders, and, with a laring disregard of precedent, filled their places with younge men than as yet had ever been entrusted with important comminds. Boscawen in command of the British flect intereepted French re-inforcenents, and in 1758, Louisberg was captured together with Cape Breton and Prince Edward Islinds, while Forbes and Washington succeeded in carrying Fort Duquesne, the nume of which wis now changed to Pittsburg, in honour of the great minister whose schemes promised so greatly for the future of the British Empire. Under the present plan, General Amherst was, with the main body of the British troops to attack Fort 'liconderora, Prideaux with a force of colonists and Iudians was to lay siege to Fort Niagara, an] then press on to Montreal, while General Wolfe, who hiul just come frou England with reinforeements was to sail up the St. Lawrence and effect a junction with the other two. Then the combined arnies were to strike a decisive blow at the French power in its great stronghold of Quebec.

The first part of the plan worked to almiration. Forts Ticonderoga and Niagara were captured, and the French driven from the country lying between Pittsburg and Lake Erie. But here for the moment, the scheiue was checked.

The settlements on Lake Champlain opposed an uncxpectedly obstinate resistance to Amherst who was consequently delayed. Montreal too held out brively against Johnson, so that 
when Wolfe, who had arrived as arranged, sailed up the St. Lawrence, he found himself on the Island of

The Capture of Quebec. Orleans, before Quebec, unsupported by the colleagues from whom he had anticipated assistance and with no prospect of their speedy appearance.

To add to his difficulties, Quebec was from its position practically impregnable. It stood on a tongue of elevated land, between the river St. Charles and the river St. Lawrence. On the water side, the cliffs sank sheer to the river, some three hundred feet below: on the land side the city was guarded by the Plains of Abraham. Wolfe, after a fruitless bombard. ment, crossed the river and attempted to carry the position by storm. The attempt was a failure. The English were, as might have been expected, repulsed with heavy loss. Every attempt to draw the wary Montcalm from his position of vantage was unavailing. For six weeks, Wolfe saw his men wasting away in sickness and inactivity, while he himself lay prostrate, ill alike in body and mind.

The case seemed desperate, and Wolfe determined upon 8 desperate remedy. He determined to climb, under cover of night, the heights behind the town, heights reputed inaccessible, and which therefore the enemy had taken no thought to guard. With muffled oars the boats crept up the river. Not a voice broke the stillness save that of the young general himself who repeated in low tones, to those who sat with him, Gray's "Elegy Written in a Country Churchyard," then in the height of its fame. "Gentlemen," said he, as he finished the beautiful lines, "I had rather be the anthor of that poem than take Quebec." The landing was made, and the troops, animated by the spirit of their leader, swung themselves up the sloping cliff by the aid of the bushes and grass, until, when morning dawned, there appeared before the eyes of the astonished French general, the whole British army drawn up in battle array on the Plains of Abraham. Montcalm had been taken 
unawares. He had been outmanceuvred, but he could still fight. He prepared at once for the attack. The advince was received in ominous silence by the Jritish. Orders had been given that the English tronps were not to fire till they could sec the whites of the enemy's eycs. The men fell fast. The general himself had been twice wounded, before the French had reached the distance required. At last the word wits given to fire, and the blow so long delayed fell with dendly effect. The French line wavered. Then the order was given for the whole linglish army to advince. The charge brolie through the French line, and the troops which composed it scattered in all directions. But Wolfe, Who spite of his wounds had headed the charge, fell back in the moment of victory, a musket bullet in his breast. "They run, they run," eried an oflicer, who had received him in his arms. "Who run?" exclained the young general, rousing from his stupor. "The French," was the reply. "Then thank God, I die happy," he murmured. The victory was a decisive onc. It was the death blow of the French hopes of an Annerican dominion. The heroic Montcalm survived his defeat but one day, and the city capitulated five days after. On the battlefield, a column murlis to posterity the spot where the gallant Wolfe fell, and in the governor's garden stands a stately monument to his memory and to that of his chivalrous foc.

Early in the following year, Montreal surrendered, and with its fall, the whole of New France passed into the posses. sion of Britain. The surrender was confirmed in the Treaty of Paris, 1763, which "ceded and guaranteed to his Britannic Majesty, in full right, Canada with all its dependencies," and provided England with another grent groul of American colonies to tuke, in time, the place of those she was destined to lose twenty rears later.

Canada and the States.- The surrencler of Canadn to Great Britain did not end the troubles of that colony. The inhabi- 
tants, some sixty thousand in number, were mainly French in origin, and their control was now vested in a few British ofticers and traders from the older settlement, who, in their endeavours to lay hold of the best portions of the conquered colony, vastly intensified the ill-feeling which existed between the conquerors and the conquered. The Quebec Act of 1774 attempted to obviate the evil by confirming the French in their possessions and civil rights on condition of their taking the oath of allegiance to the British Crown, but the measure only succeeded in rousing the English population without pacifying the French.

In the War of American Independence, which began with the battle of Lexington in 1775 , the rebels against the Home Country looked for assistance from the conquered Canadians, and endeavoured, in attempting the subjugation of that country, to strengthen their own cause by the addition of $\approx$ population inimical to Britain, while, at the same time, weaken. ing the latter by adding another to her list of foes.

The attack was at first successful. General Montgomery succeeded in carrying Chambly, St. John and Montreal. But Arnold-afterwards to win notoriety for his treason-fared badly in his attack upon Quebec. Even when the victorious forces of Montgomery came to his assistance, the town still obstinately resisted. Montgomery, remembering Wolfe's ex. ploit, attempted to repeat it. The attempt failed, and the besiegers, struck with terror at the terrible slaughter among them, ignominiously retreated. The siege lingered on for some months, but nothing of moment was attempted, and at last the appearance of reinforcements from England sent the invaders home in hasty retreat.

The fusion of the two races in Canada was soon seen to be a matter of the utmost difficulty. Apart from the difference of language, of manners and customs, it was impossible for two distinct races, brought together under circumstances so pro- 
vocative of hostility, to realily amalgamate, and it was but natural that the French Canadians should feel dissatisfied with their position in the colony. Of this dissatisfaction the United States of Ameriea again attempted to make use when, in 1812, war arose between them and England. "We can take tho Canadas without soldiers," said the Secretiry of War in Congress. "It is only necessary to send oflicers into the provinees and the people disalfeeted towards their own government will rally round their standard." The States were mistalien. Agrrieved as the Canalians were, they desired redress rather than revolt, and had no wish to exchange the government of England, whatever its faults, for the form of government offered by the States. Regiments of Canadian militia were speedily raised to assist in repelling the expeeted invasion. Thrice the Amcricans crossed the frontier, but each time without success. Then, in 1813 , the attack was renewed, Toronto was surprised, and for some months the invaders were masters of a great part of Upper Canala, but the autumn brought reverses which more than neutralised their former successes, and they were compelled to retire. In the next spring the attack was renewed with some snecess. But this was again transient, for the cessation of the preat European war freed England's hands, a large armament was despatched, and the seat of war promptly transferred to the Statos. But Britain received as much injury as she inflicted, and peace was signed at Ghent on Christmas Eve, 1814.

The English and French Canadians.-The war had the effect of temporarily uniting the French and English in Canada. It did more. It showed that ouly in a cordial union might the colony hope to find security agriust future attacks from the States. Against this union, rarious circumstances militated. The French wero practically unrepresented in the government, which was carried on from hume by means of a 
set of officials who were really ignorant of what the country needed and what it felt. The example of their American neighbour before them, the colonists determined upon an effort to shake off, at least some of the abuses under which they suffered. A manifesto to the government met with no response. Discontent spread. The Assembly refused to vote supplies. For four years no taxes were raised, the officials in the employ of the government received no wages, and the government itself came to a deadlock. Then, in 1837, the smouldering discontent broke out into open

The Rebellion of 1837. rebellion. The revolt was easily sup. pressed, but the event roused public opinion at home on behalf of the colony, and in 1838 the Earl of Durham was sent to Canada to report on the measures necessary for the organisation of a satisfactory system of govern. ment. He reported in favour of a union of the two Canadas under a local government, responsible to the Assemblies and practically independent of England, and, in 1810, this was caxried into effect. Since that time the career of the colony has been one of uninterrupted tranquillity and prosperity, and the French population, though still attached to its own manners and customs, has entered heartily into the arrangement by which it peacefully shares its political rights with the English. The governorship of Lord Elgin, 1847-1854, may be said to have organised Canada into a natiou, so greatly did he reform the representation, improve the administration of the law and labour to convince the colonists that the independence granted them by the home government was no empty show but a real license to manage their own aflairs.

British Columbla.-In 1856, the dizoorery of large deposits of gold along the bea of the Fraser River and in Vancouver's Island hrought about a large influx of prospectors and diggers. In accord ance with the general rute these were followed by emigrants seeking other and more orderly methods of industry, the population rapidiy 
increased, towns sprang up, and in 2571 , the district was adnittud into the Dominion of Canadt.

The Hudson's Bay Territory.-The Hudson's Bay Compluy was incorporuted under a charter granted by Charles II. to I'runce Rupert and seventeen other nobles and gentlemen, securing to thu the monopoly of trale in the areas eomprised by the hasins of the rivers draining into Hndson Bay. The district was known at first as Prince Rupert's Land. At the time of the conquest of Canada is had only a few "forts" and sowe hundred and fifty servants. After 1763 , fur triders flocked to the country, and a rival oompany-the North-West Fur Company of Montreal-began a dang rots rivatry, The contest ended, in l-yI, by the amalgamation of the two com. panies. In 1859, the Government refused to renew the charier and the monoyoly linsed, the district being now open to all. Tise original possessions of the company were transferred th the Govermment in lis, and, in the followin? rear, the distric: wis incorporated in the Dominion of Canadn, and the Corporation now trades as a private company. 


\section{SECTION II.-SINCE 1858.}

Between the union of Upper and Lower Canada, in 1840, and the American Civil War (1861-1864), there is little in Canadian history to record, except the commencement of the Grand Trunk Railway and the signing of the Reciprocity Treaty with the United States in $\mathbf{1 8 5 4 .}$

Canada was at this time a house divided against itself. There were, indeed, two systems of cleavage. First, there were the united provinces of Upper and Elements Lower Canada with a single legislature, on the
of

Disunion. one hand; and there were, on the other hand, the maritime provinces of New Brunswick, Nova Scotia, Prince Edward's Island, and Newfoundland. These maritime provinces enjoyed exceptional advantages with regard to European and oceanic trade, while (Upper and Lower) Canada was practically land-locked, not only by its distance from the sea, but from the fact that the St. Lawrence is closed every year during sereral months in winter. The former, therefore, (i.e., Canada proper) had to depend almost entirely on her trade with the United States. It was this which led to the Reciprocity Treaty of 1854, under which both countries prospered remarkably. But the great Inland Canada, although united by Act of Parliament, was divided against itself. The Upper portion, with Toronto for its capital, was English and Protestant; while the Lower country, with Montreal and Quebec for its chief towns, was French and Roman Catholic. The Upper country, again, was rich, enterprising and progressive; and, while contributing an ever-increasing population and revenue, complained that it was quite inadequately represented in the common Legislature. The English element, too, (such as it was) in the Legislature, 
tended to divide into two opposing parties, accurding to the traditional prineiple of English polities; while the Freuch element, being without this tradition, and, therefore, beinn united, could hold the balanee, and thus rule the situation in the Legislature. As Canada proper, moreover, was practically eut off from the ocean, so the Upper province (Ontario) was cut off eren frem the mouth of the St. Lawrence.

It was snch considerations as these that led Mr. Jackson Galt and others to advocate a federal union of all the Canadian

Provinces. With this object a Conference, Federalisation. attended by delecrites from the different provinces, wet at Quebec in 1864, and came to conclusions favourable to federation. There were dificulties with Nova Scotia, and also with England, which at first looked askance on the project; but the najority of Canadians were in favour of the measure, and in March, 1867, the Imperial Parliament passed the British North American Act, pro. viding for the voluntary union of British North America under the title of the "Dominion of Canada." By this Act, a Canadian Parliament was established, consisting of two Houses, viz., a Senate, whose members are appointed for life by the Crown, and a House of Commons, elected by the different Provinces for five years at the longest, ench province sending a number of representatives according to its population. No property qualification is necessary. The House chooses its own Speaker. The Executive is in the hands of the King, delerited by him to the Governor-Generil assisted by a Privy Couneil. Besides this ferieral govermment each province has its Legislature to look after its own affirirs.

The Dominion, at first, consiste $i$ of the four provinees of Ontario, Quebec, New Brunswiek, and Nova Seotia, alone. And even in one of these, Nova Scotia, there soon arose a viclent agitation, under Josepls Howe, for repeal of the union, on the ground that her people had not been fully consulted 
before the passing of the measure, and that the interests of the Province had been sacrificed. This danger was only arerted after much negotiation, and a certain modification of the terms upon which Nora Scotia had entered the union.

The other provinces joined the union later on, as follows:The Hudson Bay Company sold its territories to the Dominion in 1570, and from part of these territories Manitoba was formed, and annexed to the Dominion in the same year. The half-breeds in that country, who were indeed very cavalierly treated, resisted annexation, and tried to organise a revolt under Louis Riel. The rising (known as the Red River Rebellion) was, however, easily crushed by Colonel Wolseles, and Riel male his escape for the time being. It will be better to anticipate here the rest of Riel's career. Besides Manitoba there remained the vast undefined region, known as

Louis Riel.

the North West Territory, to be dealt with. In those regions the half-breeds had been dealt with even more unjustly than those in Manitoba; for while the latter received 240 acres of land a-piece as compensation for the loss of their previous rights, the former received nothing at all. There was talk about compensating them, and the Government was empowered by Act of Parliament to satisfy them. But nothing was done. Under these circumstances discontent ripened into resentment and exasperation. In the previous rising Riel had been guilty of putting to death with great brutality a loyalist named Thomas Scott. For this murder, while a general amnesty was granted to the rest, Riel and another were sentenced to five years' banishment, which period Riel spent in Montana as an American citizen. In March, 1885, Riel, who had received a deputation from the half-breeds of the Territories, returned and, placing himself at their head, proclaimed himself "President" of a Provincial Government. He then captured a Government post, and seized the stores. 
In a couple of months, however, h. was defoited and capture l, and being tried at liegina, was found guilty of treatson and hanged.

British Columbia entered the Dominion in 1871, on eondition that her seaboard on the Pneifie should be conneetrd by railway with the eastern railway system of Canadil.

Prince Edward Island joined the Dominion in 1s7:3, and Alberta and Saskatchewan (formed out of the distriets of Alberta, Assiniboia, Saskatehewan and Athabasea) in 190.5.

Newfoundland - with its dependeney Labrador - never joined the Union, and still remains independent of the Dominion.

In federating her provinees, Canada had a choice of principles; she might have adopted a "rigid constitution," defining sharply the powers to be wielded by the Central or Federal body, and giving all other powers, not so definel, to the local or provincial legislatures. This was the plan adopted by the United States, and afterwards by Australia. Or she might have given the Local legislatmres eertain defined powers, and made the Central legislature the residuary legatee (so to speak) of all powers not included in such definition. Mindful of the trouble and dificulties which the United

The Federal

Plan.

states Congress had had with the local or winor state legislatures, which from time to time claimed large, undefined powers-sometimes entirely fatal to Federation-Canada chose the latter prineiple; and defining rigidly the powers of the provincial legrislatures, gave all the other unlefined powers to the Central or Dominion lerislature. By this means a great deal of trouble and danger has been avoided; nevertheless foramuch as the intividual provinees bear a far latrer proportion to the whole Dominion than the individual American sitites do to the United States Commonwenltls, the tendency in Canala has been to allow a more and nuve liberal.interpretation of the 
powers defined and assigned to the provincial governments.

After the Union had been effected there were several problems of greater or less moment to be faced. One of the first was that of appellate jurisdiction. In the British Isles the House of Lords is the highest Court of Appeal for the three Kingdoms. It was felt in Canada too to be desirable that there should be a common central Court of Justice. Accordingly, a Supreme Court was established, like that in the United States, with appellate jurisdiction both in eivil and criminal cases, for the whole Dominion. An appeal from this court lies to the Judicial Committee of the Privy Council at home, a feature neeessary to render Canada judicially a portion of the British Empire (1876).

Another task to be faced was that of the great Railways. Two systems had been contemplated as a condition of Federation; one to unite the maritime provinces (Nora Scotia and New Brunswick) with the upper St. Lawrence; and secondly, the Canadian Pacific, to unite the Atlantic with the Pacific coast. The former of these was duly begun, and was completed in 1876. The latter was found to bristle with difficulties. At first it was intended to carry it out as a great public work; but this being found impracticable, it was resolved to hand it over to a private company. But what with incompetent companies, want of money, alternative schemes, Mackenzie-Macdonald rivalry, changes of ministry, and royal commissions, the work-to the extreme dissatisfaction of British Columbia-continually hung fire, and it was not until 1885 that it was an accomplished fact. That success was finally achieved was due to the genius of Sir John Macdonald, Sir Charles Tupper, and Mr. Donald Smith (after. wards Lord Stratheona). The Canadian Grand Trunk Railway is now one of the largest and most important in the world.

The Fisheries formed another question that had to be faced. By the Reciprocity Treaty of 1854 , the United States 
had a right to fisls in Canadian waters. This Treaty cunc to an end in 1866, and negotiations for renewal failed. Yet the Americans continued to fish as before. This gave rise to seizures, confiscations and reprisals. At length a joint Commission met at Washington in 1871, and arranged terms by which the Americans should be allowed to fish in Canadian waters on paying Canada an indemnity, the amount of which was to be fixed later on. Another Commission accordingly met at Halifax in 1877, which to the great surprise and disappointment of the United States awarded Canada the sum of five and a half million dollars. The American Secretary of State, MIr. Evarts, sought to challenge the awrurd; but it was, with some reluetince, paid in the following year. A new treaty regulating the whole fishery question, agreed upon at Washington in 1888, was retoed by the United States Senate, and since then fishing has becn earried on by the Americans on a system by which the latter take out and pay for licenses.

The Bering Sea seal fishery eaused another ditijeulty later on, and several Canadian vessels in the Pacific were seized by the United States. In 1892, this matter was submitted to arbitration, and Canada was awarded damages to the amount of four hundred and sixty-four thousand dollars for the seizures. At the same time a satisfactory agreement was come to on the future eonduct of the seal fishing.

The San Juan boundary question constituted another difficulty of long standing. In 1846, the boundary between Oregon and Canada was settled, not withont some danger of a rupture between Great Britain and the United States. Both countries had nodified their claims, and the boundary was fixed so as to include the whole of Vancouver Island within Canadian Territory; but the Gulf of Georgia and the Straits of Juan de Fuca, south of Vancouver, are full of islands, and the exact water boundary had never been agreed upon. The chicf point in dispute was the position of the island of Sun Jum; 
and the island was occupied by both powers in a joint military occupation. At length in 1872 the question was submitted by arbitration to the German Emperor, whose decision was in favour of the United States.

But the subject of Foreign Trade constituted the most absorbing of all Canadian problems. Under the Reciprocity

Protection. Treaty of 1854 with the United States, Canadian trade had been carried on smoothly and happily. If Upper and Lower Canada were partially at the mercy of the maritime provinces in the matter of Atlantic trade, they were in an admirable position for commercial intercourse with the northern portion of the United States. And this intercourse they enjoyed by the treaty already mentioned. After the American Civil War, however, the authorities at Washington, thinking that they had Canada in their power, resolved to utilise the opportunity so as to make annexation the only alternative. They therefore gave notice to abrogate the Treaty of 1854, which they accordingly did in 1866. Canada replied by pushing on the movement for Federation; which, being accomplished in 1867, consolidated Canada and placed all internal trade relations on an equal footing. New markets for Canadian trade were sought for in the West Indies, in Europe and elsewhere; so that instead of languishing as was anticipated, Canadian trade nearly doubled itself in the years that followed the abrogation of the 1854 Treaty. After the seven years of plenty, however, there came a period of dearth and leanness such as had never before been experienced in Canada. A cry for the protection of native industries then arose, and the whole Dominion became divided into camps on this question. The elections of 1878 turned almost entirely on the question of Protection, and the Protectionists came in with a large majority. They then declared what was termed the "National Policy," which was "to prevent Canada from remaining a "slaughter market' 
for American manufactures"; and further, "to select for a high rate of duty, those articles which were manuficturel or could be manufactured in Canada, and to leave without additional duties such articles as werc neither made nor likely to be made by home manufacturers." *

- This became the stereotyped policy of the Dominion, and its adoption in 1878 seems to have saved the situation. It checked the stream of emigration of Canadians to the Unitcd States, weakened the voices of those who were already clamouring for commercial union with America, and initiated a new period of prosperity. When Sir John Macdonald, the great exponent of the National Policy, issued his last election address (February, 1891) he reviewed the results of Protection in the following words: "When in 1878 , we were called upon to administer the affairs of the Dominion, Canada oceupied a position in the eyes of the world very different from that which she enjoys to-day. At that time a profound depression hung like a pall over the whole country, from the Atlantic ocean to the western limits of the Province of Ontario, beyond which to the Rocky Mountains stretched a vast and almost unknown wilderness. Trade was depressed, manufactures languished, and-cxposed to ruinous competition-Canadians were fast sinking into the position of being mere hewers of wood and drawers of water for the great nation dwelling to the south of us. We determined to change this unhapy state of things. We felt that Canada, with its agricultural resources, rich in its fisheries, timber, and mineral wealth, was worthy of a nobler position than that of being a slaughter market of the United States. We said to the American, "We are perfectly willing to trade with you on equal terms. We are desirous of having a fair reciprocity treaty, but we will not consent to open our markets to you while yours remain closed to us.' So we inaugurated the National ('Tarilf Reform) policy.

\footnotetext{
- Lucus, Vul. r., p. 305.
} 
You all know what followed. Almost, as if by magic, the whole face of the country underwent a change. Stagnation and apathy and gloom-aye, and want and misery too-gave place to activity and enterprise and prosperity. The miners of Nova Scotia took courage; the manufacturing industries in our great centres revived and multiplied; the farmer found a warket for his produce, the artisan and labourer employment at good wages, and all Canada rejoiced under the quickening impulse of a new-found life. The age of deficits was past, and an overflowing Treasury gave to the Government the means of carrying forward those great works necessary to the realisation of our purposes to make this comtry a homogeneous whole."

There was still a Liberal Party however which advocated accommodation with the United States; but that country had already adopted a high protective policy, and by the Mckinley Tariff of the States large duties were placed upon Canadian raw products. The Canadian Liberal Party therefore lost ground. But after the death of Sir John Macdonald (1891) a modification of the "National Policy" was advocated with some success; and when Mr. Laurier, a "Moderate Protectionist" became Prime Minister, he was able to initiate a new departure. This was effected in 1897 , the principal feature of the alteration being a preference of $12 \frac{1}{2}$ per cent.rising in 1898 to 25 per cent. on British goods. In 1900, this preference was further raised to $33 \frac{1}{3}$ per cent. (i.e., below the duties imposed upon the goods of other nations). This Tariff was somewhat modified in 1907, but not to any material extent; and its effect has been to check the falling off of British exports to Canada, and also to stimulate greatly the Canadian trade with Great Britain.

In the working out of the Dominion Constitution there has been (as observed above) some friction between the Central government sitting at the Federal Capital of Ottawa, and the 
various loeal govermments sitting in the provineial eapitals. This however could hardly be otherwise, owing to the great ditliculty in defining "local interests," outside which the provincial chambers were not to legislate. On questions of the franchise, licensing, edueation, railways, national defence, etc., there has been a good deal of difference of opinion, and now and again something like a dead-lock has been thentened. But a morlus vivendi has always been found at lengtl, and on the whole the constitution has worked out with reasonable harmony. In Mr. (now Sir Wilfred) Laurier, Canada has found a most able and liberal-minded suceessor to Sir John Macdonald.

One diffienlty of international inmortance renains to be noticed-the settlement of the Alaskin bound:ur. When Great Britain began pushing out her Canadian elaims

Alaska

Boundary. westwards, she found that Russia claimed Alaska; so, by a treaty between that country and Great Britain in 1525, a delimitation (though a rather vague one) was mapped out between Alaskir and British North America. Prinee of Wales's Islanl was issigned to Russia, and the Canadian boundary was to run from the south of that islaud through Portland Channel, and striking the Continent at $56^{\circ}$ North Latitude, was to proceed northward parallel to the windings of the eoast, but not more than ten narine leagues inland; and Great Britain was to have the free navigation of the rivers flowing into the Pracite. Futile attempts had been male to lay down a more exact boundary, but it was not thought worth while to spend money on the subject, when in 1867 the United Sticte; purehased Aliski، from Russia. The boundary question was still left in abeyance, until the diseovery of gold in the Yukon distriet (August, 1896), when a great rush to Klondylie took place, and a more preciso boundary definition beeane impreative. Negotiations still for some time proved abortive, and it was 


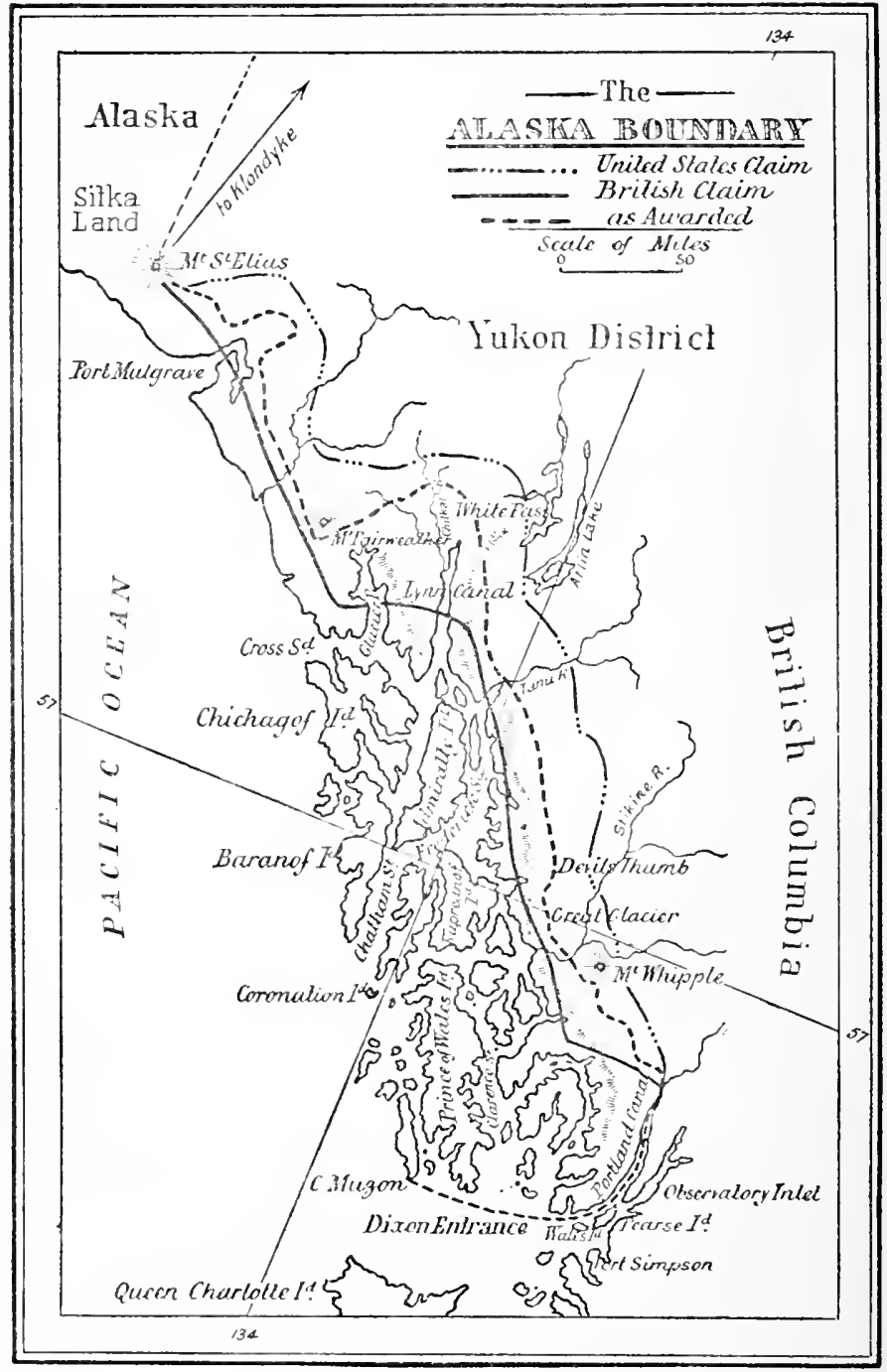


not until 1903 that a joint Comnission was agreed to of three American and three English and Canalian jurists. The chief questions were (1) What was the Portland Channel? and (2) Was the inland limit to go round the estuaries of the rivers, or to cut aeross their mouths? In the result the Commission decided on these points in favour of the States, the English representative (the Lord Chief Justice of England) voting with the three American against the two Canadian Commissioners. The verdict gave the United States control over the maritime approaches to the Klondyke goldfields, together with two islands situated near the proposed terminus of a projected Trans-Canadian railway. The issue was reeeived in the United States as a brilliant diplomatic victory, but it was regarded in Canada as a betrayal of her interests by the mother country.

There are now about 23,000 miles of railways in Canada, and trade and commerce have progressed prodigiously in recent years. The total value of Canadian Recent exports in 1904 was $213,000,000$ dollars; in Progress. 1908 it had risen to $280,000,000$ dollars. The total value of imports during the same period rose from $251,000,000$ to $358,000,000$ dollars. The wheat exported to Great Britain in 1905 was valued at $£ 2,000,000$, and in 1904 at $£ 8,000,000$.

Education.-Each Provinee has its own university (or universities), thirteen in all; and the average attendance of students is about 20,000 . 
CHAPTER V.

\section{$\longrightarrow 0-$ \\ The British in the West Indies. \\ $-0-$}

SECTION I.-BEFORE 1858.

Tre important archipelago known as the West Indies received its name from Columbus when, in 1492, he sighted the little island of San Salvador and concluded that he had succeeded in his daring attempt to reach India. Together with all the wainland of America, the Spaniards laid claim to these islands. Here their earliest settlements had been made, and hence they drew their first cargoes of gold and silver. But the mineral wealth of the islands was soon exhausted; the mines of Peru proved far more attractive, the Spanish planters failed to recognise the inexhaustible source of riches that lay in the fertility of the soil, and the West Indies fell into neglect. Other nations with a keener eye to their advantages soon showed themselves covetous of them, and, with the waning of Spain's power at sea, there came numerous attempts on the part of the other great colonising nations to wrest from her, possessions whose value she despised.

The first of Englishmen to trade with the West Indies was Sir John Hawlins, who proceeded thither in 1562 with a cargo of slaves from the Guinea coast, and won for himselt unenviable notoriety as the founder of the horrible traffic in flesh and blood which flourished under the name of the "slave triule." Queen Elizabeth, however, awarded him a baronetcy, 


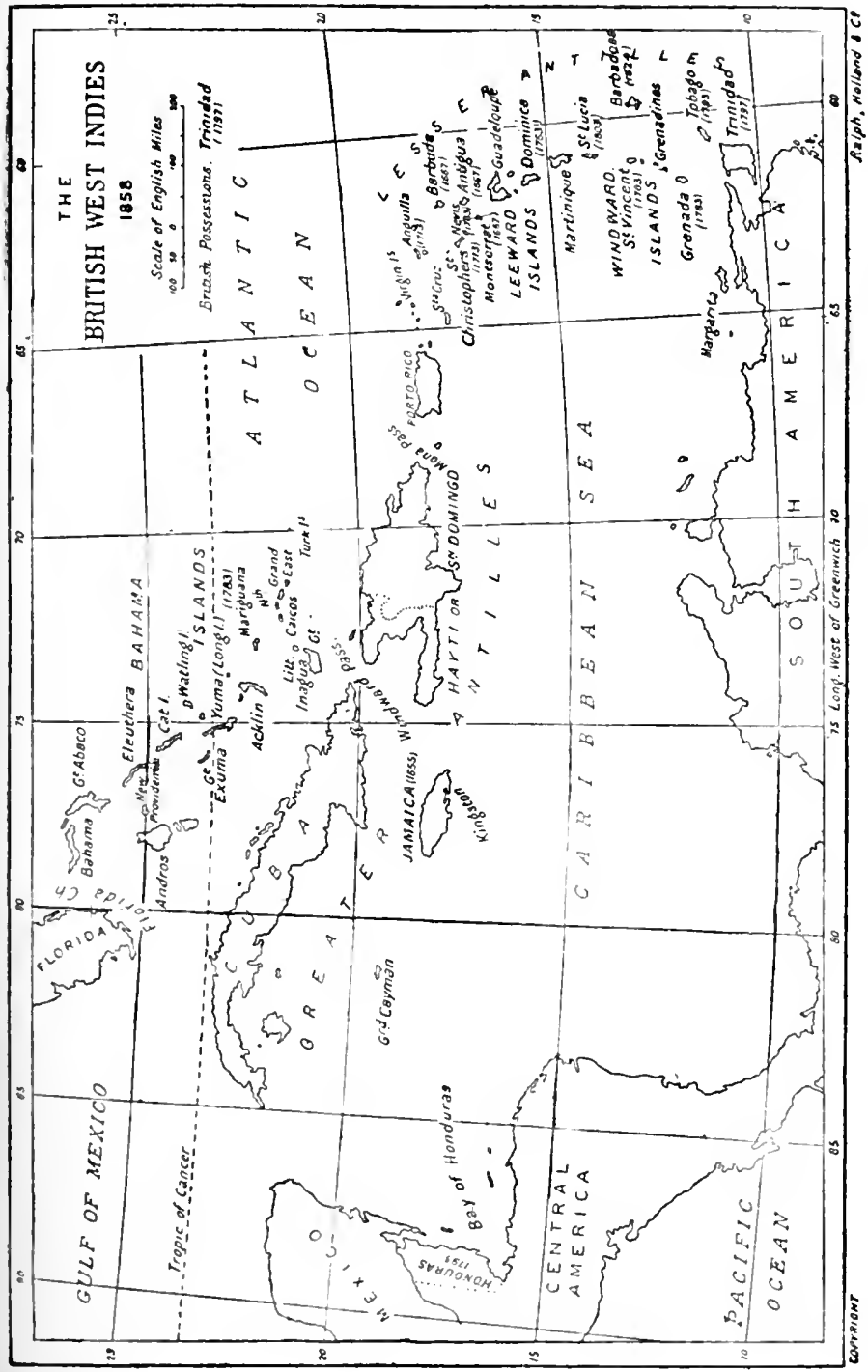


with the power to add " a negro in his proper colour, bound and captive" to his coat of arms.

His last voyage was disastrous. He was utterly defeated in an unequal contest with the Spaniards, many of his men were slain, and others taken captive and sent into Spanish slavery. But the disaster served only to intensify that hatred of Spain which was rapidly growing among English seamen. Adven. turer after adventurer sought revenge and plunder from the Spaniard in the Spanish Main, and many small settlements were made on various islands in the West Indies by the buccaneers, who found them convenient for the purposes of refitting their ships when damaged by storm or by the shot of an enemy.

The Spanish Main.-The Spanish Main was the name given to the northern coast of South America, from the mouth of the Orinoco to the Isthmus of Panama, and was sometimes extended to include the chain of islands which, with this coast, forms the boundary of the Caribbean Sea. it is not infrequently applied to tha sea itself.

Barbadoes.-One of the first of the West Indian islands to be colonised was Barbadoes, first settled by a London merchant, Sir William Courteen, in 1605, and this island, hardly larger than the Isle of Wight, became during the whole of the seventeenth century our most important colony, save only the settlements on the mainland of America. Its fertility was immense, and rich cargoes of indigo, cotton, wool, tobacco and sugar were sent howe every year from its plantations. To those plantations also were shipped thousands of slaves from the coast of Africa, and not a few white slaves-prisoners of war or debtors from the English jails. Thus, in 1657, some seven or eight thousand Scots, eaptured at the Battle of Worcester, were shipped to the Indies, the majority of whom found their way to the Barbadoes. Seven years later there began a new epoch in the history of the island, for in 1663 it, 
together with the other Caribbean Islands, was taken out of the hands of the old proprietors and placed under the dircet authority of the Crown.

Jamaica, the chief of our West Indian possessions, is an island nearly forty times the size of Barbadoes, and is note. worthy as the place chosen by Columbus as a refuge when the ingratitude of Ferdinand of Spain and the treachery of the agents of the Spanisi court forced him to flee from Spain. Time after time the fertile island had been harried by the lawless buccaneers of the Spanish Main without any permanent settlement having been effected, or the original Spanish planters, now sunk in indolent ease and vice, being displaced. Indeed, the island remained the headquarters of the buccaneers long after it had been added to the British possessions by the force which Cromwell despatched to the Indies under the command of Admirals Penn and Venables, in 1655.

The history of Jamaica has been, on the whole, a tragical one. On the 7 th of June, 1692, without any previous warning, the whole island was desolated by an earthquake of the most appalling kind, by which chains of hills were riven asunder, the river courses changed, and whole plantations trans. planted to other parts of the island or swallowed up by the immense fissures which opened in the ground, while the number of the dead was such that the putref ying corpses ured a pestilence which carried off three thousand of those who remained. The next year, when a new Port Royal was rising on the shores of the sea that had swallowed up the old, one of the hurricanes for which the island is famous, but one of exceptional violence even for Jaunica, swept over the island, carrying away the greater part of the houses that had been rebuilt. Nor does the tale of misery end here, for, in the following year, the ill-fated island was ravaged by a foe not less destructive than the tempest. Du Casse, the French governor of Hayti, swooped down on its shores with a powerful freet 
and fifteen hundred troops, harried the south and east of the island, plundered and devastated a vast number of plantations, and, though ultimately defeated and compelled to retire, bore with him a great booty and some thirteen hundred slaves. There was yet another descent from Hayti during the War of the Spanish Succession in 1702, in repulsing which the famous Benbow met his death, as so gallant a seaman must bave wished to do, in the moment of victory. Ten years later another storm swept the island, desolating its eastern side.

The history of Jamaica is indissolubly bound up with that of the nefarious traffic in slaves. Between 1655, when the island came into English possession, and 1807, when the inportation of slaves was prohibited, it is estimated that the number introduced was no less than 800,000 . In the latter year the negro population numbered 360,000 , and statistics show that from then to the final emanicipation of the slares, in 1834, the number decreased at the rate of two thousand a year, in lieu of increasing by about three thousand, according to the ordinary laws of population. The same statistics prove, to the indelible disgrace of the planters, that the decrease was due to the annual loss of some three thousand slaves by ill-usage.

Long, in his "History of Jamaica," asserts that the early West Indian planters "thought it no greater sin to kill a negro than to knock a monkey on the head," and summarises the law of the island on the subject as follows: "If a white man murders a white man, be ought to die for it; but if a white man murders a black-man, he ought to be acquitted," while no punishment, however atrocious in its details, seems to have been thought too terrible for 8 black who so far forgot the inferiority of his race as to lift a hand against a white.

At this time, too, the mountains and the thickest recesses of the woods were infested by runaway negroes or their descendants, who had criginally been the slaves of the dispossessed Spanish planters. These "maroons" roamed the island in predatory bands, eeeking occasions for robbery and violence, fornenting an insurrectionary spirit among the slaves engaged upon the plantations, and, not iufrequently, inoiting them to open rebeilion. 
Under such conditions, it may be readily imagined that the slaves were constantly breaking into olen revolt. As in such insurrections they were aidod by their outlawed brethren from the hills, it is not to be wondered at that the risungs were accompanied with the nost revolting incilents of cruelty, the whites being commonly surprised while asleep, and butchered in the most savage manner with the accompaniment of all the horrors a barbarous invention could suggest. It is even more saddening to reflect that the punislument inficted for such crimes was not inferior in horror. Even the most brutal of crimes comunitted by savages can harlly justify the barbnrities inflicted in the name of justice. The treatment meted out to the negro population was such as to degrade them to the level of the brutes. In consequence, the efforts made to ameliorate their lot and to arouse a spirit of independence and manly dignity, succeeded only in rendering them more turbulent and unruly. Thus, in 1832 , after some twenty years of such efforts, there oceurret the most terrible of all the insurrections among the slave population. For scveral days the rebels held the upper hand, giving way to every demonstration of fury and lust, and the rebcllion was not quelled until the whole island had been placed under military law. Then the blacks submitted, under promise of parton, and returned to their plantations, only to find that their owners were not in the least inclined to endorse the lenimey of the military, and that a terrible retaliation was yet in store. Altogether about a dozen white men had been murderel, most of whom had earned an undesirable reputation for the eruel treatment of their slaves. In revenge for this, more than fifteen hundred negroes were executeri, some after the merest semblance of a trial, while others without even a warning, were shot down where they stood. In allition, large numbers who were shown to have tuken part in the insurrection died unter the lasb of their infuriated masters. The report of these 
proceedings thrilled England with horror. The arguments that Clarkson and Wilberforce had so eloquently adduced against the ungodly traffic in human flesh and blood acquired a new force from this bloody retribution and the massacre of the rebels in Jamaica, doubtless contributed in no small degree to the general emancipation of the slaves throughout the British dominions, the act for which was passed by the British Parliament in the following year (1833).

Effect of the Abolition of Slayery.-The sbolition of slavery has, however, not been all unmixed good. All the institutions of the island were planned for $z$ eondition of slavery, or wcre the outeome of it, and have proved themselres strangely unsusted to the state of freedom which now prevails. The fertile plantations of the island display signs of neglect, its whole appearance is indicative of indolence and mismanagement. The negroes, freed from the bond of slavery, and without that moral elevation which is essential to the proper use of ireedom, hare fallen for the great part into apathy and discontent. Indolent by disposition, and no longer forced to work, the negro has chosen laziness as the better part in a climate where the fruit of the soil suffiees for sustenance, and has shown himself definitely averse from work either for his own benefit or for that of another. This disinclination to labour has led to the im. portation of large numbers of coolies, but the more enlightened of the negroes have of late, under the efforts of missionaries and benevolent planters, risen considerably in the scale of civilisation. As a natural result their wants have increased, and with them the inducement to labour. Black settlements have sprung up in various parts of the island, and already the results begin to appear both in the charicter of the population and in the amount of the exports.

Intigua. - Perhaps the inost important of cur early West Indian possessions, with the exception of Jamaica and Barbadoes, was the island of Antigua. It was colonised in 1632, by Thomas Warner, the buccaneer. In 1666, a descent of the French from the neighbouring island of Martinique, resulted in the devastation of the island. In the next year, however, Lord Willoughby, placed it once more on a favourable footing by sending thither plauters from his colony of 
Barbadoes, who speedily availed themselves of its unrivalled advantages for the cultivation of the sugar cane. IIere the atrocities of the slave trade were recognised at a far carlier date than in Jamaica, and its rigours mitigated. In 1834, too, Antigua alone, of all the West India Islands, chose to give complete liberty to its slaves, instead of making them pass through the period of probation permitted by the Act and adopted by the remainder of the British West Indian Islanls.

Here also the results of the emancipation seem to be of a more encouraging nature than elsewhere, the blicks, perhaps as a result of their previous stite of comparative liberty, having accommodated themselves to the new conditions much more readily, and gradually settled down into a thrifty and indus. trious section of the community.

The Bermudas.-Older than any of the British possessions in the West Indies, are the curious islands known as the Bermudas, a group of isolated rocks said to be as numerous as the days in the year, but of which twelve only are inhabited. On one of them was wrecked, in 1593, an English navigator, Henry May, who with the twenty-five survivors of his crew passed five months upon them, ere they succeeded in building with the scanty means at their command, a bark to carry them safely to England again. The same fate befell Sir George Somers, while on his way to take office as deputy-governor of Virginia. He took possession of "the still vex'd Bermoothes" in the name of Queen Elizabeth, and returned to found a small colony there, where he died in 1611. Their position, six hundred miles to the east of the coast of America, made them of great value to a trading nation, as an ocean halting place, and ever since their discovery they have remained in British hands. Their annexation to America was proposed by Washington, who saw in their possession an inestimable means of harassing British trade. To prevent their ever buing turued to such a 
purpose, they have been fortified until they are almost impreg. nable. In addition a dockyard has been built, the entrance to the harbour eleared, and the Bermudas made one of the principal maritime stations of the British fleet in the Atlantic. To the southwest lies the greater group of the Bahamas. One of these, New Providence, was settled by England in 1629. The islands during the sixteenth and seventeenth centuries formed a favourite battle ground for the English, French and Spanish fleets, besides serving as the head-quarters of the buccaneers.

Trinidad, a square shaped island to the north of Guiana, ostensibly forming part of the West Indies, but really lying on the continental shelf, was long a useless and negleeted possession of Spain. In 1797, when it was eaptured by Sir Ralph Abereromby, its population numbered some seventeen thousand, which has inereased tenfold in the period during which it has remained under British rule, while the resources of the island are being, year by year, more fully exploited.

[The Continental possessions of British Guiana and Honduras though, strictly speaking, no part of the West Indies are most conveniently dealt with here.]

Guiana had long been the aim of the hardy adventurers of Elizabethan times, who sought by exploring it to reach the fabled El Dorado, with its golden eity of Manoa, there to win such riches as the world had never seen. The golden phantom had lured many on to death. Others following it achieved lasting glory. Balboa sought it and found the Pacific; Pizarro, in its quest, conquered the empire of Peru. Our English Raleigh had gone thither in 1595, and it was the scene of the last luekless venture of his adventurous life. Using the golden fable to work upon the eupidity of James I., he procured his own release from prison in the hope of finding the wherewithal to 
sate the monareh's greed. The land is hot and pestilential, like all the littoral of the Caribbean sea, but with a soil luxuriantly fertile and, in the uncleared districts, covered by a dense growth of prineval forest, all but impassuble to man. Sugar is the staple product, and sugrar mills and ruu distilleries are landmarks in each village. The territory was first settled by the Dutch East India Company in 1580, seized by Britain in 1796, restored in 1802, recaptured in 1803, and finally confirmed to Britain in 1814 .

The Venezuelan boundaries of British Guiana bave until now never been clearly outlined-a large traet of country laving been claimed by both. The mutter was referrel to arbitration, and qva finally deciled, greatly in England's favour, in $18.4 \%$

Honduras.- "Her Majesty's Settlement in the Bay of Honduras" owes its origin to the log-wood cutters who frequented the coasts of Central America. The settlements which sprang up were the scene of frequent eontests with the Spaniards, and resulted in a Convention by which the Spaniards, while not ceding the territory to Britain, granted certain rights of trading and settlement and certain tracts of territory to the British. In 1798, the two nations being at war, a determined attempt was made by the Spaniards to dislodge the British, and the repulse of this has been considered as virtually an act of conquest. At any rate, the comiry is now governed as a Crown Colony. 


\section{SECTION II.-SINCE 1858.}

With the exception of Jamaica, there is little in the recent history of the British West Indies worth noting. The annals of Barbadoes, Antigua, Trinidad, etc., consist of administrative re-adjustments (steam and telegraphic communication with Great Britain), slight alterations in mercantile activity, sporadic railway development, and incipient education.

Jamaica.-After the troubles of 1834, Jamaica was tranquil, though somewhat unprogressive, and, indeed, out of joint. Many of the higher classes left the island. The legislature was at variance with itself. There was a want of economy in the public service, and financial deficits followed as a consequence. The natives had no confidence in the laws as administered entirely by white men and landlords, who (they said) were partial and corrupt. The free settlers complained that they were not free, but had to pay heavy imposts, while, at the same time, their political rights were withheld from them. Wages were low, and there was something like a class war between employer and employed. The negroes demanded free land, impartial justice and political rights; while some of them were in favour of expelling the white population altogether from the island.

Here were all the materials for a rising, and agitation fanned the flame. A Mr. Gordon, a popular leader and magistrate, was deprived of his post, with the result that indignation meetings were held throughout the island. At Morant Bay, another agitator, a certain Paul Boyle, was arrested, upon which an armed party effected a rescue. The Riot Act was read and the volunteers called out. But the rioters multiplied, and became fiercer and fiercer; they attackerl and captured the court-house, when about eighteen persons were killed and thirty wounded. The jails were then 
broken into and stores were sacked. The rebels adranced inland, attacking the plantations and killing the white people. Mr. Edward John Eyre was at this time Governor of Jimitica. He proclaimed martial law in Morant Bay and district, and encircled the place with troops. Many of the insurents were thus eaptured, and great severities followed. Foux hundred and thirty-nine persons fell vietims to sunmary punishment. A thousand rebel dwellings were burnt down. Six hundred men and women were flogged, many of them very brutally. Gordon wis arrested at finston-where wartial law did not prevail-and, being taken to Morant Bay, he was tried by court martial and executed. These procecdings produced much excitement and indirnetion in England, and Mr. J. S. Niell and a "Jannica Committee" charged Governor Eyre with excecding his powers and inflicting needless cruelty. A parlianentary commission was appointed, which, in its report, praised Mr. Eyre for his promptitude and vicrour, but declared that he had maintained martial law unnecessarily long, that the floggings were reckless, and other punishments excessive, and some barbarous, and that Gordon was illegally executed. On this report proceedings were commeneed against Eyre; but the case dragged on for years, and at length the grand jury threw ont the bill. In 1872, Parlinment decided to pay Mr. Eyre's expenses, and the matter dropled.

In 1866, the Jamaica constitution was suplressed, and the island was made a Crown colony. Many desirable reforms have since been effected, and the negroes, and indeed the whole colony, are now fairly prosperous. There are some 800,000 or 900,000 acres under cultivation, including 31,000 acres of sugar-cane, 62,000 acres of banana-farms, 25,000 under coffee plantation, and 10,000 under cocon-nut. The population is about 830,000 , of whom about 500,000 are negroes, about 16,000 whites, and the rest half.castes. 


\section{CHAP'TER YI.}

\section{$-\mathrm{O}-$ \\ Australasia.}

\section{SECTION I.-BEFORE 1858.}

Perhaps one of the most remarkable facts in the history of British colonisation is offered by the development of Australia. Anyone who, a hundred years ago had had the temerity to prophesy that there should arise in the southern seas a New Lngland, comparable in extent and in prosperity to that which the folly of her legislators had recently lost to the home country, and, moreover, that this should grow up from the very dregs of the population which, for safety and convenience, the old country had been compelled to cast out from her midst, would have been looked upon as a visionary if not a madman quite.

The island of Australia, chief of a group which appears, at some remote period, to have formed the upland of a vast continent, the greater part of which has, as a result of volcanic action, been submerged, seems to have been first sighted by those daring explorers of the fifteenth and sixteenth centuries -the Portuguese. Then the Dutch, always on the look out for fresh openings for their commerce, visited it, sailing southward from their Malayan possessions. French sailors, too, coasted its northern shores, leaving their names upon its map as mementos of their visits. It was not, however, until 1770, that any attempt was made to systematically explore New Holland, as the early Dutch navigatars had 
patriotically termed the island continent. In : int yeur, tl.o intrepid navigator, Captain Cook, sailed down its enstern coast, giving English names to its eapes and bays. Struck by the simularity of its shores on the soutn-east to those hilly coasts of Wales, which borler upon the Bristol Chanuel, Cools termed the distriet New South Wales. His survey was by no means an aecurate one, for he passerl unnoticed the mugnifiecnt harbour of Port Jackson, probally the finest in the world. At this period the American War had deprived Englun of the means of disposing of her convicted criminals by senting thun into slavery in the plantations of the carulinas, am the government was in a quandiry as to how the diniculty might best be met. The discoveries of Cook hal revived an ohl project of colonising Austratia, a proposal which had reminel in abeyance pending the settlement of the witr in Ancrica and on the eontinent. With its conclusion, the notion wis revived, and Cook's alvice sought as to the best situation for a penal settlement. He gave as his choice Botany Bay-a place which had probably little in its favour beyond the profusion of vegetation found there and from which its name vas derived. To Botany Bay, therefore, the first consirnment of convicts was despatehed in 1787. There were in all 565 mules and 192 females, of whom thirty-two died during the voytie. In charge of the draft were 208 soldiers, and these were accompanied by sixty-five women and children. Captain Phillip. who was in command, howerer, rejected Botimy Bay as the site of his settlement, in favour of Port Jackson, on whose shores he founded the little conviet station

Port Jackson. of Sydney, so-called after the colonid secretary under whose direction the pirty had been sent out. The prisoners were to provide for their own sustenance by the cultivation of the soil in the same way as in the Americin plantations, save that here they were working for their own livelibood only and nct for the bonetit of a purchiser. 
The soil was, however, by no means of the most fertile description, and in 1791 a more suitable spot for a farm was chosen at Paramatta. At the expiration of his time a convict was given a plot of land and the necessary implements of culture, thus becoming a proprietor in his own right. In after years many of these emancipated convicts grew wealthy from the results of their labour, and their number was augmented by the immigration of free settlers. Then the government farms were discontinued, and the convicts, as they arrived, were, if well behaved, distributed among the private farmers, or, if refractory, set to work in "chain-gangs" on the public roads.

The early history of the settlement is by no means a pleasing one. The practice of shipping off men and women, the majority of whom had no knowledge of farming and no settled habits of industry, to a coast where the natural means of subsistence were few and a livelihood was dependent upon the precarious produce of the soil, was likely to be productive of considerable misery. A poor summer reduced the unhappy populace to the point of starvation, half rations were common; now and again, indeed, they were reduced to subsist upon pounded grass and the flesh of wild dogs. Meanwhile, fresh cargoes of convicts kept arriving. The moral tone of the settlement, too, was anything but satisfactory. The governor was compelled to employ the services of the worst of the ruffians among the convicts to keep the rest in order. The presence of the troops sent out by the government proved a fresh source of disorder. They claimed, and obtained, from the government the monopoly of the supply of rum to the colony, and this beverage became, ere long, the principal article of in:portation. It was not merely a beverage, it became the current medium of exchange. The bottle of rum was the unit of mercantile value, and it is recorded that an oflicer of the $102 \mathrm{nd}$ regiment bought with a hogshead of the stuff a hundred acres of land, which he distributed in half-acre grants among his men. Half 
this plot fetched no less than $£ 20,000$, when put up to auctiou, some seventy years later.

The reformation begins with the expulsion of the governor, Captain Blyth, by the better class of the colonists, and the advent in his stead of Governor Macquarie. Ho set out with the fixed idea that the best way of reforming the convicts w:ts to mikke them free men with a stake in the country at the earliest possible moment. Pursuing this view, he endeavoured to cultivate the industries of the colony, employing all those who had been trained in handicrafts, rebuilding the town of $\mathrm{S}_{j}$ dney, and extending the boundaries of the colony in every direction. His rule lasted for eleven years and left deep and permanent results. "He found a garrison and a gaol, and left the bruim] and deep foundations of an empire."

Others, at home and abroad, joined in the good work. Not the least promineut among these were the freed couvicts, the "emancipists," many of whom now showed themselves men of high character and great auility. Favourable reports of the colony reached home, and the circulation of the news that the convict station was rapialy becoming a free colony in which honest industry had much to ginin. brought out a steady and ever-increasing stream of English and Scotch settlers, the resources of the colony were more and more rapidly developed, and its surrounding farm settlements pushed more and more decply into the country. Macquarie returned in 15:2, leaving behind him a colony four times as popnlous and twenty times as great as that which he had found in 1511.

The grow th of the colony inland, led to the discovery of the magnificent pasture lands lying beyoud the Blue Mountais.. Macquarie began a shcep roa! leauling inither. Long before its completion, however, settlers had driven The their flocks toward the duwns, to find that
Bquatier they throve better and produced fincr fleeces there than in any other spot in the world. Macarthur, one of 
the leading colonists, and formerly an officcr in the New South Wales corps, made exhaustive experiments as to the effect of the climate and pasturage upon the character of the wool, and concluded that the future of the colony lay in its sheep farms, and that its staple export would be wool. Proceeding to England, he laid the results of his experiments before the government.

His Majesty George III., as a special favour, granted him a small flock of the Spanish merino sheep, then only procurable by royal favour, since it was death to export them from Spain, and the Privy Council granted him a vast tract of land. Soon the merino breed was well established in the country, and others were brought from England, India and the Cape, all with the most surprising success. The beneficial effects of the climate can hardly be over-rated. Bad fleeces were made good, good oncs better, and the "wool-gathering" theories, as people had contemptuously styled Macarthur's plans, began to find the fullest realisation. Sheep farming rapidly became the chief industry of the co'ony, and sheep farmers spread with their flocks over immense areas in the interior of the country. They were termed "squatters," from their habit of settling wherever they could find pasture, and secured their runs by the payment of a small quit rent to the government.

In 1807 , Australia exported 245 lbs. of wool ; in 1834, when Macarthur died, no less than $2,246,933 \mathrm{lbs}$. were sent to England. Five years later and this was trebled, the value to Australia of the output totalling nearly half a million sterling. Nor did England fail to benefit, for the introduction of the fine Australian wool gave a vast stimulus to the woollen industry.

The success which had attended the settlement of Sydney, naturally led to the exploration of the remainder of the continent. Expeditions with this object, had been sent out by Captain Phillips in the earliest days of the colony, but little had 
acerued from them. In 1795, two young onlices of the lirlinned, Bass, a surgeon, and Flinders, a midshipman, determinel upon that series of investigations which lias placel their numes on the roll of fune as the heroes of Austrilian discoviry. In a boat, cight feet long, and appropriately naned the Tom 'Thumh, they suececied during the next two years in thoroughly explor. ing the coast round sydney. Then the

\section{The}

Explorers. fante and value of their exploits led to their obtaining facilities for more anbitious efforts. In larger bonts and over greater arens they pursued their work, exploring in 1702, the const of Tasmumilu, until then deemed part of the continent. This wis their last royage together. for in the same ycar, Bass, returning on a vicit to Ingland was lost at scib. Flimlers continued his work, ant in 1801 and 1802 sailed in the Investigntor, romd the southern coast to the Great Anstralim light, and then, retracing his path, started in a fresh direction and with characteristic care unapul ont the northern coast, spending a hundred and five days in surveying the shores of Carpentaria Bay. Othr expeditions followed. but the end was a traic one. He set out for England with the charts of his discureries, but, ealling at Mauritius, was held prisoner by the l'rench. Here his charts were talien from him and the crelit for the discoveries malped upon them, claimed for the French explorer, (antain liandin. When he reached Fingland, he foum it impossible to obtisin eredence for his explnits, and determined to gitin justice by the publication of his journils. He suceceded in arranting them for the press, but lind on the very day which saw the completion of his task. In 1813, a pass was fomd neross the line Momtains, hitherto dened insurmonnituble, und journeying by whis route, Governor Macqunie nnd his lady hid the fonndations of the town of Pathinst. The roud now forms the great western highway of the eolony. From this time the work of exploration has procecded apace, though with resuits hardly 
commensurate with the efforts of the explorers and the dangers braved by them. Among the chief of the gallant bands that have brared the perils of a desert land, where water was scarcely ever to be depended upon and nature afforded little for the sustenance of the travellers, are the names of Oxley, Erre, Stnrt, Leichhardt, and Sir George Grey, whose journeys, if devoid of striking incident, exhibit a patient endurance rarely equalled. Sturt showed conclusively that the interior did not, as had been imagined, consist of a rast inland lake, and discovered the river, which he nanied after the governor of New South Wales-the Darling-tracing its course to its confluence with the Murray. Mitchell discovered the area, now forming part of Victoria, which from its beauty and fertility he named Australia Felix, and to his surprise found it already settled by two groups of colonists from Tasmania, who had, in founding Port l'hillip, laid the foundations of a colony afterwards to become one of the wealthiest of all the Australian settlements.

Australian Exploration.-The history of Australian exploration has been a tragic one. Some few instances may afford an idea of the perils to be braved in the land of "Spinifex and Sand." Eyre left Adelaide and a year later reached King George's Sound in Western Australia with a single native boy, the sole survivor of a numerous retinue. His prorisions had given ont, his horses died for want of water, his followers deserted or died from hunger or thirst. Sir George (then Lieutenant) Grey met with equal hardships and endured similar privations, while haring to contend against oontinual attaclis on the part of the natives. Leichharit, who, in 1846 , started with six whit inen, two natives, flfty bullocks, thirteeen mules, twelve horses, and two hundred and seventy goats, has never since been heard of. No traces even of his party have been found by the many expeditions which have gone in search of it, and its total disappearance forms one of the great mysteries of Australian exploration. Of Kennedy's party of twelve men three only survived the privations of the journey and the attacks of the natives. 
One of the most eurious of the dimeoveries oumect..] with the early settlement of Victuria was the disecrery of an En lishnanWilliam Buckley - a consict who had eseaped from durince and lived for thirty years among the nborighes, whe langunge ton hud aecuirod and hy whon he was treated with all the eonnitran $n$ due to a chief of their own race. Indeet, for a long time the ideis seems to have prevalibd anong li:e natives t:all the whitus were their departed friends returnel to life.

Yictoria.-The Discoxery of Gold.-The new settlemrnt grew with rapid strides, forming at first part of $\mathrm{New}$ South Wales, whose governor, Sir Richard Bourlie, 1rersotully superintended the laying out of the towns of Melbourne and Geelong. The rapidity of the growth may be gauger from the

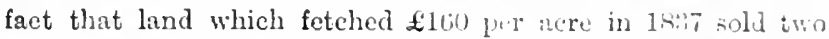
years later for $£ 10,000$ per acre, while twelve yeurs later still it fetched elose upon $\& \$ 0,000$ per aere. By the month of March the population of Port Phillip district hai risen to 77,345 , of whom 22,143 were collected in the town of Mel. bourne, which in 18 s consisted of a few hnts embowered in the trees and presenting the appearance of an Indian villen..

In the year 1851, wool ceased to be the strple of Austrilian commerce. That year is a memorible one in the bistory of Victoria for two things. It wis the date of its linth as a separate colony ; it was the year of the discovery of grolu. The gold was first found near Hathurst, in New South Wales, but shortly after the richest gold field the world has ret seen was discovered at Ballarat in Victoria, and immediately the worh was startled by the discovery of a new El Dorado.

Stray rumours of the presence of gold in Australiz had pre. viously been current. In 1836 , a convict proinced a luntuet, which he stated that he had found in the interior. II failed,

The Gold Fever. however, to point out tlie pline, and it was concluded that he had stulen a watch, melted the ease, and alopited this ingenious method of getting rid of his plunder. His reward wis a humbel 
and fifty lashes. In 1839, traces of gold were discovered by Count Strzelecki, an eminent scientist, who also pointed to indications of its wide distribution. The authorities, how. ever, feared the effect of the announcement on the criminal population, and the discoverer consented to keep his secret. Some ten years later a Mr. Hargreaves, an old Cali. fornian miner, was struck with the similarity of the geological formations round Bathurst and those of the gold-bearing districts of California. As a result he began prospecting, and in May, 1851, announced his success. There was an immediate rush of adventurers to the spot, while prospectors in other parts of the colonies carried on their researches with feverish vigour. In September all previous finds were eclipsed by the great discovery at Ballarat. Then ensued a veritable exodus from the towns, the streets were deserted, rents fell to vanish. ing point, property became a drug in the market. All forms of business were arrested. Ships that had brought cargoes of emigrants lay deserted and rotting in the harbour. Men of all classes forsook their vocations to try their fortune on the gold fields. On the field itself the scene beggars description. There were gathered the scum of the earth. Wealth, easily acquired, was as quickly dissipated in riot and excess. For some months, too, it was impossible to organise a police sufficiently powerful to cope with the lawless crew that flocked to the diggings, deeply smitten with the gold fever and recking nothing of the means they employed, provided only that the precious metal were secured. The terrihle scenes, which might be witnessed in the towns nearest the diggings, when the fortunate niners came up to dissipate their earnings, were of a nature to cause sober citizens almost to wish that there had been no great discovery of gold at all.

The effect on the population of Victoria was wonderful. In the three years from 1851 to 1854 it had risen from 77,345 to 236,776 , by $18 j 7$ to 410,766 . The effect on the prosperity of 
the colony was even greater. The output of gold from Victoria

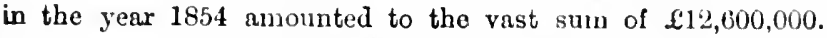
The production of this vast amount of wealth could not fail to benefit the colonies in many ways. Manufactures of all kinds throve, while in the back districts the squatters still reared their flocks and procluced yearly immense quantities of wool. At this time more than half the population

The Efrect on the Colony. derived their livelihood, directly or in. directly, from the gold ficlds. Great rlis. content, however, prevailed among the digrers, laroly as a result of the fee demanded by the government for a license. This culminated in an outbreak-the Ballarat riotwhich required a force of regulars to be sent up from Melbourne to quell. The rioters had thrown up earthworks and built a stockale on a hill near the diggings. This was stormed by the police, not without considurable loss of life on both sides, and the rising came to an end.

By this time, however, the Australian Colonies Act had been passed by the 3ritish Parliament, giving the colonics perunission to choose the form that their permanent constitu. tions should take. The democratic spirit

The Australian Colontes Act, 1881. rife in Victoria bollly claimed an clective Upper House, a Lower House, elected for three years and constituted on the principles of the secrecy of the ballot, the abolition of the property qualification, equal electoral districts and manhood suffiagc. In 1855, the new constitution was drawn up on this basis, and, under it, the importance of the colony has continued steadily to increase.

In all the Australian colonies the parlingiatury members are paid- $\$ 300$ a year in New bouth Wales, Victoris and Guensland: $f_{200}$ a year in South Australia and West Australia: and $\$ 100$ a year in Tasmania. They mostly protect themselves also teven agninst eacb otherl by duties on imports. 
South Australia.-The early explorers of the district linown as South Australia, furnished anything but a favourable report as to its suitability for purposes of settlement. "It is barren and in every respcct useless and unfavourable for colonisation," said Captain King, a colleague of Flinders, in 1822. Seven years later, in 1829, Sturt explored the district with very different results. "Rich soil, fine pasturage, and last, but most important in Australia, with its ever-present dread of drought, ample supplies of fresh water," all united to make the district one of singular promise to the intending settler. The colony was settled from England direct at

Wakefield's

System, 1836. the instance of a Mr. Wakefield, who noting the abuses which prevailed in the older Australian colonies, thought to prevent them by selling the land at the highest possible price, instead of maling, as had been the practice, free grants to intending settilers. In this way, he hoped to found a society more on the lines of that of the old country, and to attract the labourer by the promise of higher wages than could be obtained elsewhere. The scheme was really one for securing the advantages of the colony to the non-labouring classes, and was economically unsound. Never. theless it found ready support with the result that there arose an Australian "land-bubble," in which land-jobbers and money-lenders made fortunes, while the emigrants who bought lots found themselves deluded. The labourers, whom the prospect of high wages. had tempted to the colony, now deserted it, as did also those of the capitalists who had anything left from the wreck of their hopes and fortunes.

"Persons who had gone out with land-orders and means for rendering their agricultural speculations profitable, had fallen into land speculations after the sale of town allotments, or engaged in building operations at a high cost in the capital, and so brought them. selves to a standstill. Labourers who ought to have been dispersed over the country were congregated in the capital, demanding and receiving, as long as the money lasted, hich wages for works that 
conld not be remunerative to those who constructed them. The tros objects of colonisation hal been lost aight of in the whirl of epocula tive excitement; and when the funds, brought into the colony for legitimate employment, had been nearly all seit away for the purchase of provisions, and hundreds of tons of four had been imported at from teo to $\$ 100$ per ton, which should bave been produced on the spot for $£ 15$ to $£ 20$, the prospect of a genoral collapse appeared inovitahle."-Fortster ("South Australia ").

The measures adopted by the governor to alleviate the evil served only to increase the difhenlty. With his colony bankrupt, and its inlabitants starving, and with fresh shiploads of emigrants continually arriving, he provided employment by commeneing great public works. But these were unauthorised by the Home govermment which repudiated its liability. A loan from England tided over the diffieulty, and Sir George Grey was despatched with strict instructions to pursue a policy of economy and retrenchment. His instructions were faithfully carricd out, the depression died away and the vast resources of the colony were rapidly developed. It was found to contain the best of the corn land and so became a great source of food supply, not only for Europe but for the whole island. Wool, too, as in other parts of the island, became a valuable export. But, as in Victoria, the discovery of mineral wealth was to pave the way to rapid development. In this ease the mineral was colver. In 1842 , veins of rieh ore were found at Kapunda, and three years later a shepherd discovered the famous Burra-Burra mines, some forty miles further to the north. Mere, rich ore lay so near the surface that it could almost be raised by hand, while even the lower levels could be worked with singular ease and at but little cost.

Marvellous stories were told of the wealth which accrucd. One lueky proprietor is said, after three years of work, with an original capital of $£ 500$, to have netted a yearly income of $£ 11,000$. The wealth of the colony increased by leaps and bounds, its population grew in equal proportion and a thriving 
town sprang up in the vicinity of the mines. In 1850 , the population of the colony totalled 63,700 , treble what it had been in 1845 , and the value of the exports exceeded half a million sterling per annum. The discovery of gold in the neighbouring colony of Victoria brought, however, a time of stress for South Australia. There was a rush for the gold fields that threatened at one time to depopulate the colony. Within twelve months, more than 16,000 persons, a fourth of the whole population and the bulk of its most useful and industrious inhabitants, had passed into Victoria. The exodus was, fortunately, only temporary. The rush gradually ceased, the discovery of gold in small quantities at home induced many to return, the vast increase in the population of Victoria increased the demand for those food stuffs which South Australia was so fitted to supply, the difficulty brought about by the sudden depression in trade was gradually over. come and the colony continued to develop on the old lines and with even greater rapidity than before. Under the Colonies Act, the form of government chosen was similar to that of Victoria and the constitution was based, in 1856, on two houses of representatives, both being elective. The inhabitants, thus endowed with the full rights of self-government, have continued to progress and South Australia has shown itself among the most enterprising of all the Australian colonies.

"A remarkable development of patient and painstaking industry is perceptible over the whole colony. Its resources may not bear comparison with those of some of its richer neighbours, but, whatever those resources may be, they are certainly in course of development in a very intelligent manner. It is England in miniature, England without its poverty, without its monstrous anomalies of individual extravagances thrown into unnecessary and indecent relief by abounding destitution. It is England with a finer climate, with a virgin soil, with more liberal institutions and witb a bappier people."-Fonsteil. 
Western Australia.-The Swan river, around which clusters most of the industrial life of Western Australia, was first explored by the Dutchman Vlaming in 1697. In 1829, Captain Freemantle went to take formal possession in the name of the British Crown, and, in the same year, a band of emigrauts with horses, cows, pigs and sheep arrived to settle the country.

Other consignments rapidly followed, and the distriet was colonised before it had been sufficiently explored to determine whether the character of the country was such as to render it suitable for the purposes of emigration. Great misery ensued upon this undue haste. The district was practically barren, and the only land at all suitable for tillarge, was claimed by those in charge of the expedition. Moreover, the natives werc fierce and powerful, and showed themselves inclined to resent the invasion of their territory. Thus, though one of the oldest settlements in point of date in the island, Western Australia or the Swan River Settlement as it was first called, is still the most backward in point of development. The early setlers, disappointed in the hopes which had been founded on the glowing accounts given of the other colonies, gradually migrated to these, and by the year 1850 , when the remaining colomies were on the high road to prosperity, Western Australia seemed bordering on extinction. As a last resource, it was determined to introduce into this colony the convict labour from which the others now clamoured to be freed, and, in the next ten years, some ten thousand convicts were sent over. As a natural result, the convict element speedily predominated in the population, until the whole district resembled rather a prison than a settlement. This proved a source of annoyance to the other colonies, which were by this time making strenuous efforts to free themselves from the stigma attaching to a criminal population, and they displayed deep resentment at their neighbour's policy, which resulted in large numbers of escaped convicts finding their way eastward. 
The exportation of conricts to Western Australia ceased in 1868 , owing to the vigorous representations made by the other colonies to the home government.

Tasmanis.-This island. first known as Van Diemen's Land, was, at the time of the first settlement at Sydney, con. sidered to be a part of the mainland, and the colony of New South Wales was declared to extend from Cape York upon the north to South Cape, the southermmost extremity of that island. The explorations of Bass and Flinders, however, soon determined its real character, and the rast tract of land which had been included under the name of New South Wales was afterwards divided into sections. The first of these to be detached was the island of Van Diemen's Land, which was parted off in 1825. The new colony was used originally, like its parent, as a convict settlement, but hardly with such good results. The aborigines proved to be both powerful and quarrelsome, and soon came into collision with the Europeans who had thus invaded their country. Convicts and soldiers had, in self-defence, to unite in a war of utter extermination against the natives, which endured for almost sixty years. When, however, in 1836, Tasmania was made an independent colony under Sir George Arthur as governor, its prospects began to revive. Among the disadrantages with which the settlers had to contend, at this time, was the presence of gangs of bushrangers, for the most part escaped convicts of the worst type; men who did not shrink from the most fearful crimes. Some of the worst of them, indeed, were said to have added cannibalism to the list of their iniquities. The military present in the island were numerically insufficient for the work they had to perform, and the police force was not organised on an effective basis. The governor's hands were full, but he set himself to the task with a will. Hobart Town and Launceston, from mere convict settlements, gradually became important towns, and commerce and civilisa- 
tion spread apace. The quict being thus restored, free sutlirs came trooping into the island in increasing numbers und arled that elevation of its moral tone which the good work of the governor was bringing about. In 18it, when, like the remain. ing colonies, it had to nuke ehoice of the form of government which it considered most suited to its needs, it herine a separate colony, with houses of representatives and all the machinery of popular governumis. At the same time its name was changed to Tasmania, the old nane having biecome mpopular from its assnciation with the convicts "ho were its first settlers, and with whose crimes the num Tan Dicman's Land was too reminiscent.

New Zealand.--The history of New Zeniand is elnsely connected with that of New South Wales. Tasman first discovered the group, and is responsible for its name. William Dampier, one of the most famous of Enylish explorers, who had begun life as a buccaneer in the Spanish Miain, wis the first Englishman to visit it. Nothing memotable, however, was done until the time of the famous Cantain Cook, who, in his first and greatest roynge, in 1769. visited the islinds and endeavoured, though fruitlessly, to estallish friendly relations with the natives. His attempts, which were perhap's marlied by too great rashness, combined with too great distrust of the natives, ended almost invariably in hloodshed.

It is mufortunate that the first Englishman to have serious relations with the Maries.should have beroun a strife between the two races which has continued tull recent times, and pro. duced much misery and provoled much ill-feeling on both sides. The feeling of hatred to the whites was meatly intensified by the visit of De Surville, a French navigator, who reached New Zealand at the same time, and treated its nativs with gross cruelty. In Fresne, another Frenchnim, further contrivated to the list of grievances treasured up us the Maries 
against the whites, by his dealings with them four years later. Subsequent navigators carried on an irregular intercourse, more or less friendly, but, generally speaking the relations between the Maories and their civilised visitors have been hostile, merging every now and then, into a war of extermination, waged with the utmost determination, and under circumstances of the greatest cruelty on both sides. Murder succeeded murder and massacre followed massacre, with the view, on the part of the English, of exterminating a race of cannibals unrivalled in their ferocity ; and, on the part of the savages, with the desire of revenging the death of their friends, and the hope of obtaining by plunder those articles which their intercourse with the whites had led them to covet. The credit for the amelioration of this state of affairs is largely due to Samuel Marsden, then a missionary at Port Jackson, where he had opportunities of becoming acquainted with such of the Maories as were induced from time to time to leave the island on a visit to that settlement. With these he established, by degrees, the most friendly relations, finding that the savages were as readily susceptible to kindness as they were resentful of imjury. By his influence, the Church Missionary Society was led, in 1814, to organise a body of missionaries for the conversion of the Maories, attempting, at the same time, to introduce among them the arts of civilisation. Whaling vessels bound to the fishing grounds of the South Pacific established stations on the islands, various native chiefs visited the neighbouring Australian colonies, and one of the most important was even brought to consent to a voyage to England. Europeans gradually settled on the sea-coasts, and their stations became centres of trade among the natives, who were brought more and more within European influence. Various settlements were formed, the chief being at Wellington, Auckland and Nelson. Until 1841, the New Zealand settlements were all subject to the government of New South Wales, but in that year the three islands 
were formed into a separate colony, with the growing town of Auckland for its capital. The troubles with the natives, how. ever, still continued. Some of the more far-seeing, or perhaps the more ferocious, of their chiefs, proposed the extermination of all the settlers-missionaries, as well as traders-foresceing that intercourse with the white man must necessarily end in the gradual decline of their race, already beginning, with fatnl readiness, to adopt the worst vices of civilisation in addition to those characteristic of the savage statc.

It is more than probable that the merchints and traders engaged in the New Zealand trade, were not scrupulously honest in their dealings with the natives. Be that as it way, the trading was marked by constant disputes, and aroused the keenest ill-will between the parties engaged. In addition to this, The the products brought into the country were
Pahekas. often of such a nature as to tend to the
demoralisation of thesavages and the quarrels which broke out between the traders-the Pahekas, as they were called by the aborigines-and the native population are, at least, comprehensible. Among the worst fentures of the traffic was the trade in rum, the taste for which spread among the natives with all the rapidity of an epidemic, and with all its disastrous effects. The introduction of firc arms too, gave a deadly impulse to the feuds perpetually raging among the native tribes, and lent an added danger to their intercourse with the whites.

To such an extent did the vicious part of the trating community minister to the evil passions of the people, that these were speedily inflamed to such a pitch as bid fitir, at no distant date, to lead to the total extinction of the al,origines, a prey to the unfettered license which provailed.

"The unfortmate natives of New Zealund, ualess some decisive measures of prevention be adopted, will, I fear, be shurils abled to the number of those barbarous tribes wbo, in different parts of the 
globe, have iallen a sacriflee to their intercoura with civnised men who bear and disgrace the name of Christians. When, for mercenary purposes, the natives of Europe minister to the passions by which these savages are inflamed against eich other and introduce them to the knowledge of the deprared acts and licentious gratifications of the most depraved inhabitants of our great cities, the incvitable consequence is a rapid decline of population, preceded by every variety of suffering."-ViscocNT GoDERICH (Colonial Secretary in 1831).

One of the most deplorable of the practices which sprang up was the tratic in heads. The New Zealanders had been in the babit of dyeing and preserving as trophies the beads of their onemies slain in battie. Some of these having come into the possession of $\mathbf{a}$ trader, were carried to Europe and were secured with such avidity by curiosity-hunters, that the trade in heads became a flourishing and lucrative branch of commerce. From its nature it was suscep. tible of the grossest abuses. The available supply of heads ran short and every means, even to murder, was employed to obtain a fresh stock. It was possible to bargain for the head of a living man, and to find it delivered according to the terms of the agreement.

Thus, under the influence of the Pahekas and the mission. aries the Maories divided into two parties, both having cloaked their primitive barbarism with a veneer of English customs; the one having imbibed the worst features of civilisation while the other had profited by the example of the missionaries' peaceable and useful lives. The latter portion of the native community has now become sufficiently civilised to take an intelligent share in the government of their country and their represen. tatives sit in the parliament of the islands, while the former is rapidly becoming extinct and now proves a source of danger to the settler only in isolated districts.

This state of quietude was not achieved without con. siderable trouble and much ill feeling

The Maori Wars. which now and then culminated in opeu rupture. One deplorable instance occurred

in 1843. Disputes were constantly arising with the native chiefs on the question of the ownership of the land. Colonel Wakofield. then in command, on one of these cccasions determined 
to force the ehiefs into compliance with his desires and went to seck them with a band of armed followers, intending to eapture them and bring them in irons to the capital. The invasion was naturally resented by the natives, and orders were given to fire upon them. The result was a war between the British authorities and a confederation of the Maori clicis. The English were at first defeated, with great damage to their prestige and serious loss of life, the blame for which must be laid at the door of the English governor. As u result the English had practically to conquer the country. Tribes that had hitherto been submissive now took up arns, the outbreak spread and was not put down until a rast amonot of danarge had been done. The moderation and tact of Sir George Grey, one of the greatest of its governors, grabually brought about a pacification, although some of the more wnyl.he of the tribes fled to mountain fastnesses, where thoy secured themselves against attack and maintained a gruerilla warfare for some five years after the outbreak. The peace then establisher was apparently final. The natives, where unter good intluence. showed themselves intelligent, desirous of inprovement and apt to learn. The habits of civilisation seem, however, to enervate them and the life of cities gradually to sap the strength of a people fitted only for the free life of the wools, so that the Maori, who has protited by the lessons of eivilisa. tion, bids fair to die out even wore rapidly than his brother who has refused any dealings with either missionrrius ur traders, and preferred remaining in a state of savagery to accepting the benefits offered by the white man.

The sovereignty of the islands passed into the hands of Grent Britain by the treaty of Waltangl in 1 s!n, the chiefs being secures] in the possession of their lands and forests as long as they thesired to retain them. 


\section{SECTION II.-SINCE 1858.}

Australia.-The history of the Australian Colonies for the last fifty years has been one of almost wholly domestic interest. Until we come to the Federation of Australia and the formation of the Commonwealth in 1900-1901, the problems and agitations have been of local, one might almost say of parochial, importance. They comprise such matters as the stoppage of convict transportation from England, the exploration of the continent, and the extension of the colonies, the flow of emigration, and the exploitation of mines, the rise of a labour party, and the consequent occurrence of strike contests, the building of railways, the formation of waterworks, state education, vote by ballot, protection of native industries, etc.

Situated at the antipodes, and isolated from every other country, threatened and interfered with by no other people, (with the exception of some Chinese immigrants), Australia has had no need of a foreign ministry or a foreigu policy, but has been left to pursue her own course and develop her own resources.

Between 1855 and 1860, the Eastern States-New South Wales, Victoria, Queensland and South Australia-were accorded self-government; while Western Australia received a constibution in $\mathbf{1 8 9 0 .}$

The most important series of enactments have been those relating to the land, the object being to prevent absenteeism and the mere exploitation of the country by speculators. A whole crop of legislative measures, dealing with tillage and stock-rearing, have been passed within the last forty years.

The object of the immigration laws has been to prevent aliens, especially the Chinese, from flooding the country or 
establishing themselves on the gold-digngings. In the sixties, the scare was such that it expressed itself in serious riots, and the Chinese were hunted out of New Sonth Wales. The trouble has been, to a large extent, removed by the working out of the mines, and the "Yellow Peril" has now been reduced to a minimum. Still, in some of the states, there is a toll on Chinamen, and the number allowed to land each year is strictly limited.

In Queensland, Kinikias ("boys") have been introduced from the New Hebrides and other parts of Polynesia, for the purpose of working the sugar plantations within the tropics. At one time these lianikns were kidnupped by plinters' arents, and a great deal of eruelty was employed; and when, after three years, they returned to their native islands, they brought back with them all the viees and none of the virtues of eivilisation.

Strikes and labour troubles have also loomed largely in Australian life. Conviet labour came into collision with thit of the free immigrant; and there was yet The another elass, the tine-expired convicts, who Great Strike, sought to identify themselves with the latter.
1890. In 1890 , the labourers had so extensively organised themselves by means of trade unions that they were able to bring about what is lnown as the Great Strilie of Workmen $v$. Capitalists generally. Sydney was the headquarters of the movement, and the disturbances were sufieiently formidable to necessitate the swearing-in, in large numbers, of special constables. In November of the same year the strike came to an end, the capitalists gaining a decided victory over the labourers.

One of the labour champions, William Lane by name, led a company of strikers to South Amorica, and in Pararuay established a sort of socialist commmity (189:3). The venture, however, was harlly more successful than the Darien Schemo 
of William III.'s reign. The management of this "New Australia" was far from being harmonious, and the contests and disputes proved as numerous and bitter as they had been in the parent colons. Many of the settlers returned to Australia, while others had to be assisted back.

After the Great Strike, the labour party succeeded in getting itself represented in the New South Wales parliament, and soon afterwards in the other provincial parliaments; but the whole party soon became divided on the question of protection, and the introduction of the Caucus system further reduced its numbers and unity.

In the extension and development of Australia, the chief results have been the creation of Queensland, the exploration of the Northern territory (including the laying down of a transcontinental cable), and the colonisation of West Australia.

Queensland was carved out of New South Wales, and proclaimed a separate colony in 1859. From this time onward, many exploring parties traversed the

Queensland, 1859. great island, some of them being misinformed and ill-judged, and ending in disaster. In 1860, for instance, O'Hara Burke, William Johu Wills and others, in response to a $\$ 2,000$ prize offered by New South Wales, started off from Melbourne in that year to cross the continent. They succeeded to a certain extent; but, in returuing, their provisions gave out; they suffered terrible hardships, and seren out of eight died of starvation.* A public funeral was all the recompense that the Colony could accord them (1863).

Two years later, Stuart succeeded in crossing the continent from north to south, and his explorations led to a new

* The difficulties of Australian travel may be judged from the fact that Captain Sturt found the thermometer rise to $127^{\circ}$, upon whioh the mereury burst the glass. "Every screw came out of the boxes; the horn handles of instruments and the combs split up into fine laminæ; the lead dropped out of the pencils; the bair stopped growing, and the finger-nails became brittle as glass." 
distribution of territory, and south Australia was extended so as to include the whole country as far as the northern const. In 1870, a telegraph line was laid down from sonth to north along the route opened up by Stuart, and, in 187:, the formidable work was finished. As a result of explorations mate by Forrest, (iiles, and others, a line was laid down between Adelaide and Albany in 1877, and West Australia was brought into touch with the nore prorressive colonie: The only great stretch of territory remaining unexplored was the country between West Australia and the ecntre of the continent, and this region wits suecessfully crossed by Sir J. Forrest in 18it. "Thi, was the crown and culmination of the history of discovery. . . Oxley, Cunningham, Leichhardt, Mitchell, Sturt, Stuart, Gregory, and Forrest, did on land what Magellan, Mendaña, Torres and Cook did on sca; and the landsmen's exploits were as useful, noble, and perilous ils the sea-furcrs' exploits. Their work, which was to prepare the way for those who were to come after them, belonged to that class of work which, if well done, is nerer done again. It was finished in 1874; and from that late the book of heroes closes, and exploration ceases to be a motive force in history."

Australian Federation. - This great measure, which became an accomplished fact in 1900, had been spoken of nearly fifty years before. There was nothing to prevent and everything to encourage an Australian union. There were no natural barriers to be overcome, such as those of blood, religion, geographical position, which, in the case of Canada, presented serious difliculties; and it was only the late development of the Australian states that prevented an earlier federation. Still, the seheme had been broached as far back as 1847 , when Lord irey slietched out a federal plan, which was, however, rejeeted by the Australian legislators. The withdriwal of the imperial 
troops from Australia and New Zealand in 1870-1871 quickened the natural desire for a defensive union. Referenda were resorted to, and the result was in favour of combination. In the 'eighties, a federal council was formed, to which each of the colonies misht send members or not, as it pleased. This body, however, like Convocation in the mother-country, was only a debating society, and had no executive power and no financial standing. On the initiation of Sir Henry Parlies, a conference was held at Melbourne. Representatives from the Australian states drew up resolutions in favour of federation (1889). Two years later, a national Convention was held at Sydney, which adopted the previous resolutions almost invact. These resolutions provided for free trade between the Australian states, and while handing over to a central federal government certain defined powers, made provision that each state should exercise all other powers not so surrendered. There was not, however, a sufticient momentum of public interest behind these proposals, and the resolutions fell still-born from the Convention. The movement, however, did not expire, and though another attempt to discover a modus vivendi was wrecked by the opposition of New South Wales, the matter was brought to a happy. termination in 1900. A meeting of the premiers, held at Melbourne in 1899, managed to allay the misgivings of New South Wales; and, all the states being agreed, delegates were appointed to carry the draft Bill to. England, for the purpose of obtaining the nccessary Imperial legislation. The British goremment offered no opposition, and in 1900 an Imperial Act was passed, by virtue of which New South Vales, Victoria, South Australia, Queensland, West Australia and Tasmania were declared to be federated under the title of the "Commonwealth of Australia," on and after the 1st Januiry: 1901. 
The chief difticulty had been with regard to the right of appenl, and it was at length arreed that in all purely Australian matters the appeal should be to the Hirh Court of Austrilia: while in non-Australian cases the appral was still to be to the Judicial Committee of the Privy Council. By the original plan only ten or twelve subjects were surrendered to the federal gorernment for lecritation; in the scheme as finally adopted this number has been increased to twenty-nine.

There are two Honses in the Fecleral Parlianent, a Senate and a House of Representatives. The Senate is made up of thirti-six members (six beinir elected by each of the original states-New South Willes, Victoria, Queensland, Sonth Australia, West Austrilia and Tismanial; and it sits for six years. The lower Ilonwe is twice as large, and sits for three years. The Goveruor-General of courec represents the Crown, and his salary is $\mathscr{1 0 , 0 0 0}$ a year. The executive power resides in the Governor and a Council of seven.

Transportation to Austrulia had been abolished in $18 \%$. In 1885, the Anstrulian colonies proffered help to the mother country in the Sondan War, and in IS99 they sent con. tingents to South Africi to support the Imperial govermment in the 'Triusval Witl.

New Zealand.-It was the uncerupulous manner in which the New Zealand Company possessed themselres of the native lands that caused the Mrories to rise ayainst the colonists in the 'forties; and it was mainly land disputes that grave dise to the subsequent Mari wars in the 'sixties and the seventies.

The Mnories had no central government, and the were not able to unite or organise thenselves into a mation. Moreover, until their lands were sold to the colonist th. Maories conld 
not talie advantage of English Iaw or politics at all: yet after such bargain and sales their status was often no better. "Whenever land was bought, a re-grant of one-tenth of the

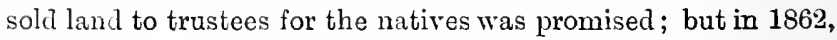
178 of these promises-many of them over ten years old-were outstanding." *

In 1857, the Maories tried to unite their tribes by electing a "King"; and a chief named Te Whero Whero was chosen

Maori King. in $185 \mathrm{~s}$ to wield the sovereign power. After his death in 1860, his son Tawhiao was ap. pointed to succeed. The spirit of unity, however, was not in the Mari nature, and the title and trappings of royalty could do nothing to bring about cohesion or solidarity. The monarch was ignored, and the tribal cliefs remained still the only real power in the Islands. In the ten years' war that began in 1860, many Maori chicfs-especially in the latter part of the war-fought on the side of the colonists. The northern, as well as the southern, portion of the northern Island was friendly: the hostile tribes occupied the central districts. Land was again at the bottom of the trouble.

The first war lasted about a year, and was destitute of important events (1860-1861). In 1861, Sir George Grey became

Maori Wars.

Governor, and immediately a period of native amelioration commenced. Grey did everything in his power to conciliate the Maories, spending money on them, meeting them in friendly conference, promoting education, making roads through the island, tolerating their "King State," etc. Notwithstanding this, war broke out again in 1863 with the murdering of eight colonial officers and men. This war may be said to have ended with the battle of Orakau, and the occupation by the British of the "King State."

In 1865, the fires of war were kindled again. The Christian Maories were expelled from the native districts, and a sect of

* Rogers, Lucas, vol. VI., p. 212. 
heretics, nicknamel Hau-lfaus, caused fresh distubances. These Maori fanatics preached a doctrine compounded of Judaism and Paganism: they believed themselves to be invincible, and they advanced against their enemies barking like dogs. Beheading their prisoners, moreover, they fixed the heads on staves, and having executed a dance before these gruesome objects, they sent them round the island. The fanaticism thus excited, expressed itself in a further attack on the missionaries, when the Rev. Mr. Volkner was mudered, and his eyes caten! (March, 1865). This savagery, however, failed of its object, for it caused many of the frienlly Maories to rally to the side of the colonists. Thus the war was no longer national or racial, but civil; or rather it became a rebellion, in which the best Maori chiefs fought alongside with the British, while some of the native clans also fought with each other.

One of the friendly chiefs was a man named Te liooti, whose loyalty, howerer, was not above suspicion. Ife lad

Te Kooti. not, perhaps, been judiciously treated; for, while he was arrested and kept in prison, he had been promised his liberty at the end of two years. Yet the two years passed, and he was not liberated. He then effected his escape, and, repairing to the east coast, he committed numerous murders, and attracted a number of desperadoes to his side. There was nothing national, or even patriotic, about his rising, and Ropata and several other clan chiefs sided with the colonials against him, while the "King" would not even grant him an interview. There were numerous fights and combats in the struggle, but the only one of real importance was that of Maraetahi, where, aided by clan chicfs and native levies, the colonials routed and dispersed Te Kooti's party.

From this point may be dated the political union of the islands, and the beginning of their material prosperity. 
"Those who prophesied a "wa" of extermination' wero widols wrong. In ten years, deaths directly caused by war were less than 3,000 ; in one year (1854) Maori deaths, directly due to measles, exceeded 4,000 . In 1874 , the Maories were 45,500 , and in the 'forties possibly 105,000 ; but wal had not made much difference. Thus, the Puhi clan of the far north had not been at war, and had more than halved, and those who quoted 105,000 as the figure for the early 'forties, quoted 56,000 as the figure for the late 'fifties. War proved less deadly than the poisoned cup of peace. Tragedy had slain its thousands, comedy its tens of thousands,"-Rogers, Ibid, $p .226$.

In 1877 , further land disputes oceurred, and in the troubles that followed great intiuence was exercised by $\mathrm{Te}$ Whiti, an

Te Whiti. enthusias ic Christian Maori, who endeavoured to carry the teachings of the Sermon on the Mount into public life. He supported the native claims, but at the same time enjoined honesty, peace, and industry, and he took as his motto, "Resist not evil." His teaching, with regard to land, was decidedly communistic, and multitudes flocked to hear him preach. Te Whiti was denounced by the colonials as a fanatic, the Maori land claims were rudely pushed aside, and Te Whiti and his friends were arrested for sedition. This high-handed conduct was condemned by many, but it proved to be the epilogue of the long war. Te Whiti eren now counselled, not active but passive, resistance, and when, after about sixteen months' imprisonment, he was released, the danger of a rising had passed away. An amme-ty was proclaimed, which included Te Kooti, who had an interview with Mr. Bryce, Colonial native minister (1883).

In 1881, the Maori King paid a visit to London, and was fêted by the Earl of Derby and others. He came to seek redress for breach of the treaty of Waitangi (1840), and to petition for native autonomy, native land and law courts, a native minister, and a more substantial Maori representation. Autonomy was refused, on the ground that colonial and Maori interests were mixed and blended in the Islands, and that the County Councils would answer all the purposes of autonomy. Certain concessions were subsequently made to 
"Maoriland," and the Fing, being reconciled, sat in the Legislative Council.

In 1893, Mr. Ballance, the Prime Minister, died, and was succeeded by the energetic and influential Richard J. Seddon.

The capital of the Islands had been moved in 1965 from Auckland to Wellington. This had been done on the adrice of New South Wales; and the Now Zealand government now further emulated Australian methods by making large loan; for public works, emigration, railway's, etc. There was, however, a good deal of trouble and litigation in the matter of the New Zealand Loan and Mercantile Agency, Charges were freely proffered against the directors, the officials, and the New Zealand government, of bribery and corruption, issuing misleading bilance sheets, etc.

Under Mr. Seddon, New Zealand progressed in a remark. able way, and a large amount of legislation was initiated during his long premiership. In 1903, an Act was passed to provide $£ 40,000$ annually as a contribution towards the maintenance of the Australian Squadron. Another Act was passed in the sume year according preference to British goods. In 1904, MIr. Seddon's "Silver Jubilee" as Member of Parliament was enthusiastically celebrated, by which time he had been fourteen years a minister, and twelve years Prime Minister. In the following year he pronounced New Zealand (reckoning the wealth per head of the population at f30s) to be the richest country in the world.

\section{GOVERTORS OF NEW ZEALAND.}

1843. Admiral Fitzroy. 1845. Sir George Grey. 1854. Colonal Wymward. 1855. Governor Browne. 1861. Sir George Grey: 1867. Sir George F. Bowen. 1872. Sir James Fergrison.
1875. Marquis of Normanby. 1879. ir Hercules Robinson. 1880. Sir Arthur H. Gordon. 1883. Sir William Jervois. 1888. Earl of Onslow. 1892. Earl of Glassow. 1897. Earl of Ranfurly.

1904. Lord Plunket. 
Tasmania.-Tasmania had reoeived representative government in 1853, in which year also the transportation of convicts to the Island was stopped. 'Responsible govermment was granted in 18.56. The able-bodied inhabitants, both male and femule, had at this time nearly all left the Island for Victoria, in consequence of the discovery of gold in the latter colony in 1851, so that Tasmania was for a time "inhabited by greybeards and children."

In the 'sixties, gold was found in Tasmania itself, and the out-put soon rose to something considerable. Taking advantage of the contrariety of seasons, Tasmania now supplies Great Britain with apples in the spring, when that fruit is very scarce in the mother country. The climate of Tasmania is eminently healthy, the death rate being only about 14 per thousand.

Tasmania became one of the States of the Australian Commonwealth in 1900 . 
CHAPTER VII.

\section{$-0-$ \\ British Rule in Africa.}

SECTION I.-BEFORE 1858.

THE colonisation of the Cape was a natural consequence of the discovery, by Vasco de Grum, that the sea route to India lay round it. The Dutch were the first to utilise its undoubter advantages as a place of call for ships on their way to the East Indies. Its advantages as a place of residence were first noted in 1648, when a Dutch ressel was wrecked upbn its coast and the crew had perforce to reside there until picked up by a passing ship, an event which did not occur until some months had elapsed. The report they made on their return to Holland induced the Dutch East India Company to despatch thither a company of emigrants with the view of making it a place of call for vessels in the India trade, and in 1652, the colony was retually planted under Jan van Riebeck. The native races, reluctant to see their land gradually passing into the possession of the strangers, were nevertheless at first friendly, but as the colony grew and they found themselves forced farther and farther inland, took, as some measure of retaliation, to stcaling the cattle of the settlers. This was, to the latter, a vastly diflerent matter from the forcible acquisition of land from the savages. and the incensed governor made war upon the natives with all the limited forces at his command. The contest proved the forerunner of many others, for from henceforth the Dutch and the natives were almost constantly at variance. Moreover. the colonists added to the grievances of the natives by lunting 
them for the purpose of using them as slaves. As a natura! result, the native races were driven further and further inland as the new colony increased in extent and in population.

In 1795, the Cape Colony was assigned to England by the Dutch, the reason being that Napoleon had invaded and conquered Holland, and the Prince of Orange was a refugee in London. The colonists lost no time in expressing their dissatisfaction with this arrangement, and the relations between them and the English were soon those of open strife. In 1502, however, the Treaty of Amiens restored the colony to its original owners, but the European war having revived, it agiin passcd into the possession of Britain, this time by conquest. Cape Town surrendered to Sir David Baird in 1806, and from that year until 1815, the country was under military law, as much to prevent the inroads of the warlike Kaffir tribes of the inland districts, as to keep down the turbulent Boer population. The new govermment did not commend itself either to its butch or native subjects. In the first place, the law that no fresh slaves were to be made after 1808, brought it into direct conflict with the Boers, while the Kaffirs who had, with good cause, shown themselves the enemies of the Boers, were treated as though they were the enemies of England also. As a ratural consequence, they speedily became so. In 1809 , the Commissioner, Colonel Collins, recommended the expulsion of all the Kafirirs within the border, and the hasty and unjust measure was duly carried out in 1811, innocent and guilty being confounded in one sweeping condemnation.

The Kafir Wars.-As a result of this measure South Africa has been from time to time devastated by Kafiir Wars, some of them on a considerable scale. The first of these occurred in 1811, when the Kaflirs, who bad been driven back over the Great Fish River, broke over the boundary aud carried their depredations throughout the farms which lay near it. They 
were, however, easily driven back by Colonel Grahaun. Tho next outbreak came as a result of the perennial cattle-lifting of which the border Kilfirs were guilty. Restitution was enforced and this led to a border war, the Kaflirs rallying in great foree and pouring into the colony in the early part of 1819 , carrying everything before their inpetuous rush. In the end, however, they were defeated with great slaughter, and British troops to the number of four thousand advanced and took possession of the country lying between Koonap Fat and the Great Fish River, which was added to British territory, while the district between its northern horder and the Keishamma was declared neutral territory. Later, in 1835, under the governorship of Sir Benjamin Durban, the whole of this tract was annexed in retaliation for another raicl, in which, stung by the death of one of their chiefs who was lilled in a border skirmish, 10,000 Kaftirs swept aeross the frontier, pillaging the homesteads and murdering all who dare! resist. This was the greatest of the Kaffir Wars of the first part of the century, and nine months' fighting was needed to reduce the country to quietude. The measures of reprisal taken by the troops, under the command of Colonel Smith, were so severe as to gain the condemnation of the home government, at this time bent upon measures of conciliation, a policy which was distasteful to the majority of the colonists, though laudable endearours seem to have been made to carry it out.

I'hus, as a result of the attitude taken by Lord Glenelg, then Secretary of the Colonics, the land seized in 1836 was restored to the natives, and our relations with them placed upon a somewhat better footing. Treaties were made with the principal chiefs, trade was encouraged and their territories secured. In 1810 there was, however, another outbreak. The authorities had arbitrarily revolied certain of the treaties, and cattle-lifting and horder-raiding rapidly assumed their old proportions. The usual invasion of the haftir territory followed 
and the struggle that ensucd was maintained fitfully until 1853, forming what are known as the fourth and fifth Kaffir Wars. Fortune at first lay with the Kaffirs, various sma!l bodies of British troops being cut off and defcated with serious loss. The rising was reduced by the efforts of Sir Harry Smith and General Cathcart, and the district placed under martial law. On March 23rd, 1853, the military law was revoked, and shortly after Kaffraria was made a Crown Colony nuder the title of British Kaffraria.

In the year 1820 there arrived at Algoa Bay some five thousand settlers from Britain, and the foundation of the eastern settlements was laid.

The Great Trek.-The Boers, the descendants of the original Dutch colonists, had, ever since the country fell into British hands, been profoundly dissatisfied with the rule of their new masters. The nature of their occupation, no less than their objection to British rule led them not infrequently to "trek" farther and farther inland in search of fresh pastures and greater freedom. It was, indeed, by this means that the colony had grown, and the authorities been brought into conflict with the natives. In 1834, the act for the emancipation of slaves came into force throughout the British dominions. This entailed a very considerable loss to the Boers, the sum$£ 1,200,000$-granted the colony in compensation, and of which barely a tithe is said to have reached the owners of the slaves, being regarded as absurdly inadequate. 'The result was the "Great Trek," of 1835-6. Hore than ten thousand of the Boers migrated with the whole of their belongings to the district north of the Orange River, and there founded two republics, which, as the Orange Frce State and the Transvaal. claimed complete independence of Britain. The clain was long disputed, but was finally concederl in 1854. A part of the number crossed the Drakenberg Mountains, and took possession 
of the district of Natal, where they maintained a precarion, resistance against the formilable Fatlir tribes of the south-easi.

After many fieree contests with the Amazulu, they werc, however, compelled in 18.12 , to seek aid from the Cape Govern. ment. Troops were sent and the Zulus defeated. Now, how. ever, the Dutch who greatly outnumbered the British popula. tion, determined to throw off the British supremacy and found a Dutch Republic on similar lines to that of the Orange liree State. Troops were sent to quell the rising, and in the end, in 1843, Natal was formally annexed to Great Britain.

The Convict Agitation.-After publie opinion in Australia had compelled the British Government to discontinue the sending of convicts there, the attention of the authurities, who had an unusually lirge number of prisoners on their hands in consequence of the troubles in Ireland, was strongly directed to the advisability of founding fresh penal settlements abroad. It was determined to ascertain the feelings of the colonists at the Cape with regard to the reception of a certain class of convicts. Before this had bcen done, however, a shipload, by somc error, had been despatched. On their arrival in Table Bay, the populace rose in a mass and sought by acts of outragcous violence to show their disapprobation of the measure, and thei? determination not to submit to the introduction of convicts The governor, compelled by the force of popular opinion, agree not to land the consignment. But this concession, apparently satisfactory as it was, proved insufficient for the more violent spirits, who now determined to prevent the ship from obtaining supplies. Finally the difliculty was solved by despatching the vessel with her cargo of convicts to Van Dicman's Land.

The agitation is, however, worthy of note since it led to tho inception of a movement to obtain a free representative govern. ment for the colony. The morement bore fruit, when in 185:; a constitution was established much on the lines of those 
granted to the Australian colonies, and the colony becams virtually self-governing.

Natal.-Port Natal was entered by Vasco da Gama on Christmos Day, 1498. Nearly two hundred years elapsed before it was thought of as a site for a settlement. Then the Dutch of Cape Colony sent an agent, who succeeded in purchasing the Bay and the land in its vicinity from its Zulu owners for merchandise-copper, cutlery and beads-to the value of 29,000 guilders. Even then the Dutch made no use of their purchase, and for another hundred years the natives were undisturbed. In 1823, Lieutenant Fairwell succeeded in winning the regard of Tchaka, the Zulu chieftain, and gained from him the permission to make a settlement. Three thousand square miles of land were granted him together with several heads of cattle. Four years later Tchaka was assassinuted by his brother Dingaan, in whose eyes the growing prosperity of the little colony furnished grounds for serious apprehension. Fairwell and some of his followers were assassinated while on a journey, the settlement raided, many of its inhabitants slitin and the remainder compelled to seek safety in flight. In 1835, another English officer, Captain Gardner, gained permission irom the tyrant to found another settlement at Durban. In 1839, the Boer "trekkers" under Retief, obtained from Dingaan the cession of the whole territory of Natal. No sooner was the treaty signed, than a treacherous attempt was made, by the Zulu chief, to extirpate the Dutch settlers throughout the length and breadth of the land. The latter, however, with the assistance of a rebel Zulu chief, Mpanda, the brother of Dingtan, proved more than a match for their assailants. In 1843, however, the colony was ceded to Britain, a result Iargely ane to the security to be attained under the British flag, and since then, wi h but few interruptions, its career has been one of prosperity. In 1856, it was created into a separate colony with representative institutions. 
The West Ifrioan Colonies.-These consist of the four colonies of Gambia, Sierra Leone, the Gold Coast and Lagos, all situated on the coast of North-West Africa between the mouthe of the rivers Senegal and Niger. They were originally trading settlements, and include some of the earliest extensions of the Empire.

The Colonx of Gaklis wh founded th carly as I6Is, but its early carcer was one of viciscilude owing largely to the competition of Euronean rivals. It was not formally lwcognised as British until the Treaty of Versailles in 1783 , and was given no political institutions until 18:07. In 1841 it was formally anuexed to Sierra Leone.

The Prowselat of Sielra Leone was acquired, in 1787, ly tresty with the native ohiefs. It was originally intenled as a refuse for liberated negroes from North Amerien and the West Indies. It is thus a colony in reality, while the others are but trading settlements. The harbour of Freetown, its capital, is the bes in West Alrica, a fact which mikes the colong a valuable piace of cail and conlin: station on the Cape route to India and the list.

Laoos, formerly one of the great centrcs of the Africun lave trade, was captured by the English in 1551, but was not formally annexed to Britain until 1861. In 1876 it was incorporated with the Gold Coast Colony, but wits formed into a separate Crown colony in $\mathbf{1 8} 86$.

Tin: Gold CoAst.-This stretcbes along the coast of the Gulf of Guinea for about 290 miles, extending inland about 300 miles. The carliest settlement was nade by English traders in 1618. In 1662 a company was chartered to trade thither, which, in 1672 , was in. eorporated with the Rosnl African Company. The settlement was, in 1821, transferred to the Crown, and placed under the goremment of Sierra Leone, from which it was not finally sepa ated till 1871. 


\section{SECTION II.-SINCE 1858.}

Cape Colony.--'There had been some friction between the govermment of Cape Colony and the Imperial government. We have seen that in 1818-1819, both the Dutch and the English colonists, young and old, and of all ranks, trades and persuasions, had united against the introduction of convict labour into the colony, and had carried their point. Again, in 1865, the annexation of British Kaffraria under strong pressure from the mother country, led the colonists to think of demanding more extended powers than those conferred on them in 1853. In other words, a movement for responsible self-govermment was set on foot, and, in 1872, it became an accomplished fact, when the colonists "took up in the fullest sense the duties and the privileges of a self-governing people." *

For some years after this, the history of Cape Colony is a record of territoral expansion, and of industrial development, of the discovery of gold and diamond fields, the construction of railroads and telegraph systems, and the establishment of steamer lines between England and the Cape.

In 1865, British Kaffraria was annexed.

In 1871, Griqualand West was annexed.

In 1868, Basutoland was annexed.

In 1874-5, Southern and Northern Kaffraria and Griqualand East were added.

In 1871, the discovery of the Diamond Mines of Kimberley and De Beers promised to alter the whole character and condition of the colony by enormously stimulating emigration and raising in like proportion the demand for land in the northern districts.

Lord Camarvon, who in 1875 was Colonial Secretary, was bent on federalising South Africa on Canadian lines, and proposed the measure in a despatch to Sir Henry Barkly, 


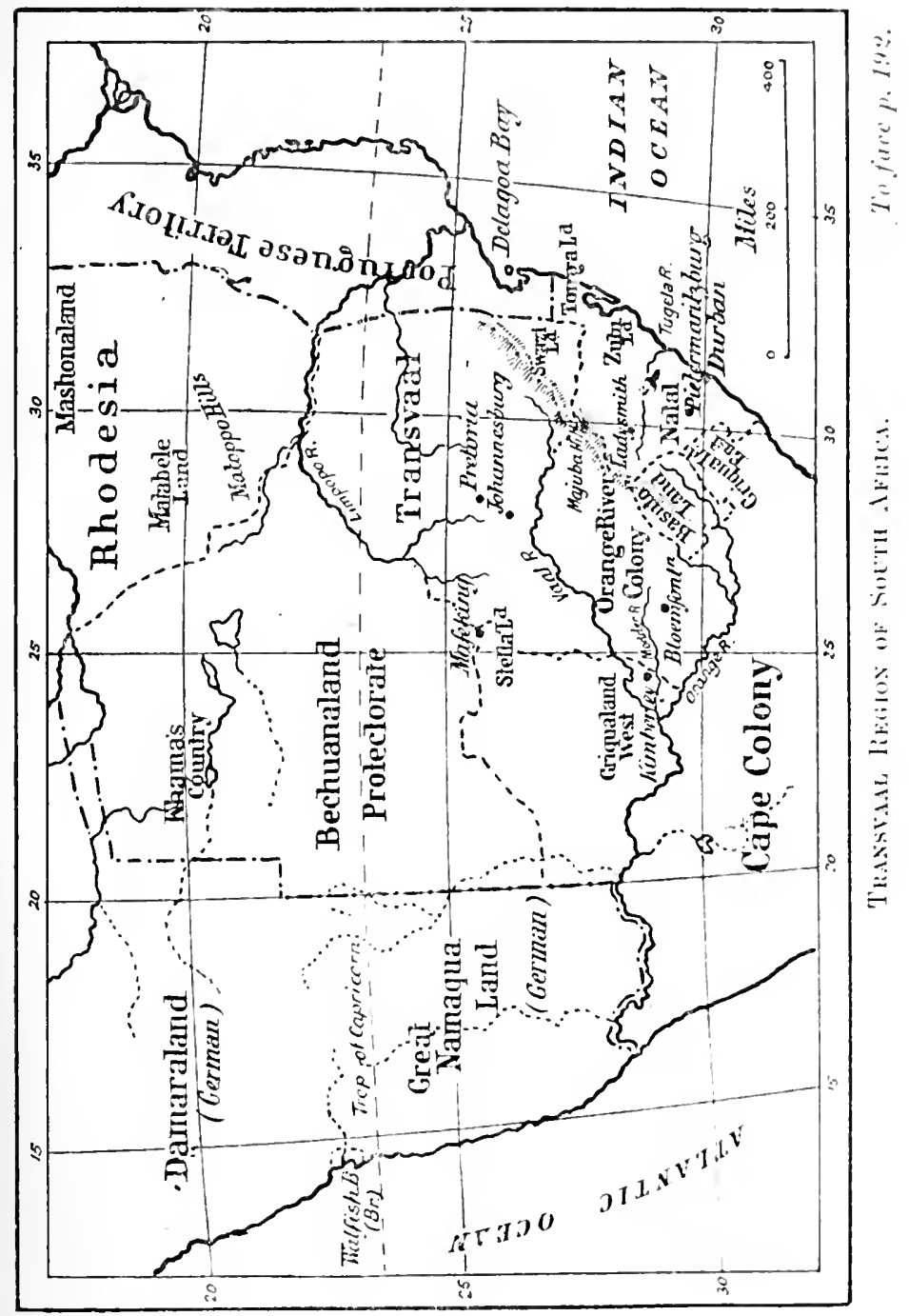



Governor of Cape Colony, while at the same time he sent Mr. Froule to itinerate the country and promote the scheme. The Cape government, however, standing on its lately aequired constitutional dignity, declared that any such seheme must originate within the colony itself. In 1876, Carnarvon, still full of his federal projects, appointed Sir Bartle Frere Governor of Cape Colony. Sir Bartle beeame involved in two or three native fronticr wars; and before these were settled Carnarvon had resigned, and the federal poliey expired. Sir Bartle Frere, who was also a High Commissioner for Soutl Africa, showed great vigour and high statesmanlike qualities, and during his administration the Transkei, Basutoland and other territories were annexed. During his regime, too, the Transval was annexed (1877).

In 1880, Frere was suceceded by Sir Hercules Robinson, under whom Griqualand West was ineorporated with Cape

\section{The Bund.}

Colony. After the Boer War of 18s1, the Africander Bund (a league or association of the Cape Dutch to promote their own interests) receired a great aequisition of strength, and became very influential,; and regular congresses began to be held. The object of the Bunel was to promote enthusiasm for Dutch nationality, until the time should be ripe to get rid of the British flag, and establish South African independenee on Duteh lines. It thus stood to the British government in South Africa some. what as the Home Rule party in Ireland stand to the Imperial parliament in England, or the Magyars in Hungary. to the Austrian govermment in Vienna. The Bund (playing the part of the Ostrogoths in Italy towards Belisarius, the Byzantine general) actually sfiered to take Mr. Cecil Rlodes for their leader; but Mr. Rhodes (re-enacting the part played by the great Belisarius) replied that they "took him either for a rogue or a fool."

"In 1902, the title of the league was changed to "South African Association." 
The Bund at this time was powerful enough to set up and pull down ministries. Its leader was Mr. J. H. Hofmeyer, who represented Stellenbosch in the House of Assembly, and edited the Vollistein newspaper. At first a friend of Mr. Cecil Rhodes, he broke with that statesman after the Jameson raid. He was a man of unquestionable talent, and his influence over his Dutch countrymen was supreme. At first, he adrocated total separation from England, but later on he became mediator between the Boers and the Cape government, and it was through his influence that a peaceful solution was arrived at on the Swaziland question. Obstinately refusing to take office, he preferred to work by influeneing other members of the Assembly; and hence he obtained the nickname of the "Mole." Directly or indirectly, however, from 1881 to 1898 , he ruled the Bund caucus.

The leading representative of British opinion in South Africa in the same period was undoubtedly Mr. Ceeil John

Cecil Rhodes. Rhodes, to whom reference has already been made. In a comparatively short career, Mr. Rhodes developed the lighest statesmanlike qualities, and he stands to South Africa somewhat as Warren Hastings stands to India. Entering the Assembly in 1880, he first took office in 1884 as Treasurer-General. In 1890, he became Prime Minister, and held the Premiership till 1596. It was through his influence that a British protectorate was proclaimed over a large portion of Bechuanaland, by which Mr. Kruger's designs on that part of Africa were checkmated. Through Mr. Rhodes's influence, too, numerous small diamond companies at Kimberley were amalgamated, from henceforward being linown as the De Beers Consolidated Mines. A Customs Union for South Africa had been already formed-a first step towards federation; the union was joined by the Orange Free State, and soon afterwards by British Bechuanaland and Basutoland. Through Mr. Rhodes's in. 
fluence, the Glen Grey Act was passed, the principle of which way to safeguard the rights and privileges of coloured people in the native reserves, and to levy upon every able-bodied l:ubourer a tax of ten shillings a year, unless he could show that he had been in service for a certain portion of the year-"In miny respects the most statesmanlike Act dealing with the natives on the Statute Book." *

The discorery of the Gold and the Diamond mines in the north had given a great impetus to railway development. Mr. Kruger (or his government), intent on cncouriging the Delagoa route to the Transval, quadrupled the traffic rates north of the Vaal River; and, when the Cape merchants endeavoured to forward their gools by wisgon from the Vaal northwards, he closed the fords ("drifts") on the river (1895). This arbitrary action led to such a vigorous protest by the home government that the fords were reopened.

In 1896, the revelation of Mr. Rhodes's complicity in the Jameson Raid raisel such a storm of surprise and indignation in the colony that he resigned the Iremiership. Another result of the Raid had been a fresh Matabele rising, and during the hostilities which ensued, Mr. Rhodes went, alone and entirely unarmed, into the very heart of Matabeleland, and, trusting to his own porsonal influence, he net the chicfs in conference in their stronghold in the Matoppo hills. This sublime bravery anl confidence, both in the natives and himself, was fully justified; for the chief eventually surrendered unconditionally, and the rebellion was at an end. By this "master-stroke of diplomacy and comrage" $\mathrm{Mr}_{\mathrm{r}}$. Rhodes bought "golden opinions from all sorts of people," and both Dutch and English colonists united to give him an enthusiastic reception on his return to Cape Town.

In 1898, Natal entered the Custons Union-another milestone on the road to federation.

- The labour clauses of this Act were repealed in 1905. 
During the South African war, there was a good deal of friction and excitement in Cape Colony, especially during the Premiership of $\mathbf{M r}$. Schreiner, the leader of the Bund party and a friend of the Boers; and between him and Sir Alfred Miluer, the new Governor of the Colony, there was a good deal of scantily-veiled hostility. The initial engagements of the war, which were nearly all British reverses, took place within Colonial territory, and had the effect of encouraging many of the Dutch colonists of the Cape to join their fellow-countrymen across the Vaal. On the other hand, the loyal colonists were, after the arrival of Lord Roberts and Lord Kitchener, recruited in large numbers for the Imperial troops. The story of Mafeking and Kimberley (where MIr. Rhodes was imprisoned during the whole of the siege) will be told under the history of the Transvaal. A Disfranchisement Bill was passed under the Premiership of Sir Gordon Sprigg - who had succeeded Mr. Schreiner-to punish the Cape rebels who had joined the Boers (1900). Martial law, which had been proclaimed in Cape Colony in the previous year, was repealed in 1902.

In 1903, Mr. Chamberlain visited Cape Town, and had an enthusiastic reception. His public speeches were directed towards healing the racial wounds that still remained. At a farewell banquet at Cape Town, he deelared that "all the divergent races which went to make up the British Empire had as their motto-" One life, one flag, one fleet, one empire."

Since the conclusion of the Boer War, the South African colonies have made such tangible progress in Federalisation, the matter of federalisation that the King's
1910.

speecl at the opening of Parliament in 1910

(February 21st) contained the following paragraph :-

"The establishment of the Union of South Africa has been fired at the end of May, when its new Gorernment will be constituted, and soon afterwards the first Parliament, representing the cansolidated electorate, will be ready to assemble for its important deliberations," "*

* For further particulars as to federation, see under Natal, 
Rhodesia.-Rhodesia, or, as it has been called, "Charterland," is divided into North and South Rhodesia, and comprises vast stretehes of country, the former principally north and the latter south of the Iiver Zambesi. North Rhodesia is sub-divided into North-Lastern and North-Western Rhodesia; it is, as yet, an ill-defined and undeveloped country; it is bounded by Lake Nyassa on the east and the Orange Free State on the west. Southem Rhodesia includes Matabeleland, Mashonaland, Barotseland, ete. These countries were managed, till 1898, by the British South Africa Company, and townships have been founded at Salisbury, Victoria, Bulawayo, etc., the first-named being the capital. The country is still governed, for the most part, according to the terms of the charter granted in 1889 to the British South Arica Company; but, in 1898, the charter was amended by Orders in Conneil, with an administrator, nominated by the Secretary of State, and executive and legislative councils were cntrusted with the government of the colony. Probably, a great future awaits this country, but at present there are not more than 14,000 white inhabitants in it. Bulawayo and Salisbury both enjoy munieipal sclf-government.

Other colonies and protectorates similarly awaiting derelopment are British Bechuanaland, Bechuanaland Protectorate and Basutoland.

Natal.-In 1879, trouble arose with Cetywayo, King of the Zulus, who had organised his army into a great "Celibate, man-slaying war machine," and by his opposi-

zulu War, tion to missionaries, his plundering raids and
1879. murders, had become a terror to Natal. After futile negotiations, British troops entered Zululand in January of that jear. At Isandlwana, however, Colonels Durnford and Pulleine, together with other officers and many men, were surprised and killed by about 15,000 Zulus. At liorlic's Drift, 
on the other hand, Lieutenants $\mathrm{Ch} r \mathrm{rd}$ and Bromhead successfully resisted an overwhelming force of the enemy. In June, a reconnoitring party under Prince Louis Napoleon (the Prince Imperial) was surprised at Imbalani, and the Prince was lilled. In July, Cetywayo was completely defeated by Lord Chelmsford at Ulundi, aiter which the Zulus agreed to a treaty by which their wilitary system was to be abolisher, and the country dirided into districts, under native chiefs, with a British resident in each. In 1852, Cetywayo came to England, and was permitted to visit Queen Victoria, the Prince of Wales, and Mr. Gladstone. After his restoration, Cetywayo was attacked by powerful native chiefs, and ciril war raged throughout Zululand. In 1884, Cetywayo died, and was succeeded by his son, Dinizulu. In 1836, a large portion. of Western Zululand, which had been overrun by the Boers, and called by them the "New Republic," was annexel to the Transvaal. In 1837, Zululand was annexed as a British possession, and in 1903, the northern districts, and other large territories, were taken orer by Natal.

The retrocession of the Transvaal Independence in 1881 had always been viewed with great dissatisfaction in Natal, and at a public meeting at Durban, presided orer by the Mayor, a resolution was passed and telegraphed to members of the Imperial Parliament as follows: "Utter disgust with settlement. British prestige with our natives entirely forfeited. No consideration for loyal Boers or British residents. Terms of peace simply mean greater bloodshed at no distant date."

In 1881-1855, the great gold discoveries in the Transval produced immense excitement in Nital, and not excitement only, but activity, speculation, emigration, wagron-work, railway construction, and so forth. In fact, Durban and Pietermaritzburg became like Genoa and Venice in the time of the Crusades, and many of the Natal colonists became mine proprietors on a large scale. 
In 1893 , responsible self-government was accorled to Natal. In 1898 (as has been said), Natal entered the South Africa Customs Union.

Political predictions are usually falsified (often ludicrously) by the erent; but that contained in the Durban telegram mentioned above was destined to be verified with a vengeanee, and Natal herself was fited to bear the initial brunt of the "greater bloodshed." In 1899, the Boers burst into northwest Natal, and the following engagements were decided in quick suecession on Natal territory:-Talana Hill, won by General Symons (who was himself lilled); Elandslaagte, victory for Sir George White; Nicholson's Nek, British reverse (surender of Colonel Carleton); Siege of Ladysmith (with Gencral Buller's campaigns, and, erentually, relief of the town). The relief of Ladysmith was followed by the evacuation of Natal by the Boers. In this war the Natal Volunteers aided the mother country materially.

Federation,-By the South Africa Bill of September, 1903 Cape Colony, Natal, the Transwal and the Orange liver Colony are to be federated within twelve months (i.e., by September, 1910). The seat of govermment is to be at I'retoria, and that of the legislature at Cape Colony.

East Africa Protectorates.-In the seramble for Africa, many Crown colonies and protectorates have been proclaimed by Great Britain, e.g.:-

\section{Zululand (see under Natal).}

Basutoland.-The Basuto power was founded by Moshesh, a chief of remarkable ambition, conrage, foresight and cunning. The Basutos were engaged in frequent feuds and fightings with the Boers, and were also a danger to Natal. Moshesh died in 1870, and, in 1s71, Basutoland was annexed to Cape Colony. The task of looking after such a wild people proved. 
however, more than the Cape government had bargained for; and, in 188t, the latter resigned her share of the honour, and gave Basutoland back to the mother country. Since then Basutoland has been treated as a crown colony, and it promises to be a real success in the near future.

North of Natal, Great Britain possesses in East Africa no colonies, only protectorates, or crown colonies, administered by the Colonial Office or the Foreign Office. These consist of Uganda, Nyassaland, Zanzibar and Pemba. The difficulty and expense of administering these countries is sometimes great. Until 1895, Zanzibar was governed by the Imperial British East Africa Company, which had been chartered in 1888 , and which, in 1895 , surrendered its rights to the Imperial government. The Germans had declared a protectorate over Witu, but, in 1890 , they withdrew this protectorate in favour of Great Britain.

The annexations by Germany on the east coast had made Great Britain uneasy for the horizon enjoyed by Aden. In 1885, therefore, the government proclaimed Somaliland-the African territory opposite Aden-a British protectorate, and stationed a few soldiers at Berbera, on the coast. This, it was thought, would effectually safeguard Aden's "ancient lights." By the year 1910, however, the difficulty-not to say absurdity-of assuming to "protect" a country four hundred miles long and about a hundred and sixty miles broad (or twice the size of Ireland) by means of a single regiment was sufficiently appreciated; and the home governinent has now cntirely abandoned the interior, and determined to concentrate its protective attentions on one or two places on the coast.

West African Protectorates, etc.-On the Gold Coast the Dutch and the English both had settlements of long standing. These settlements were not colonies, but protectorates; rent 


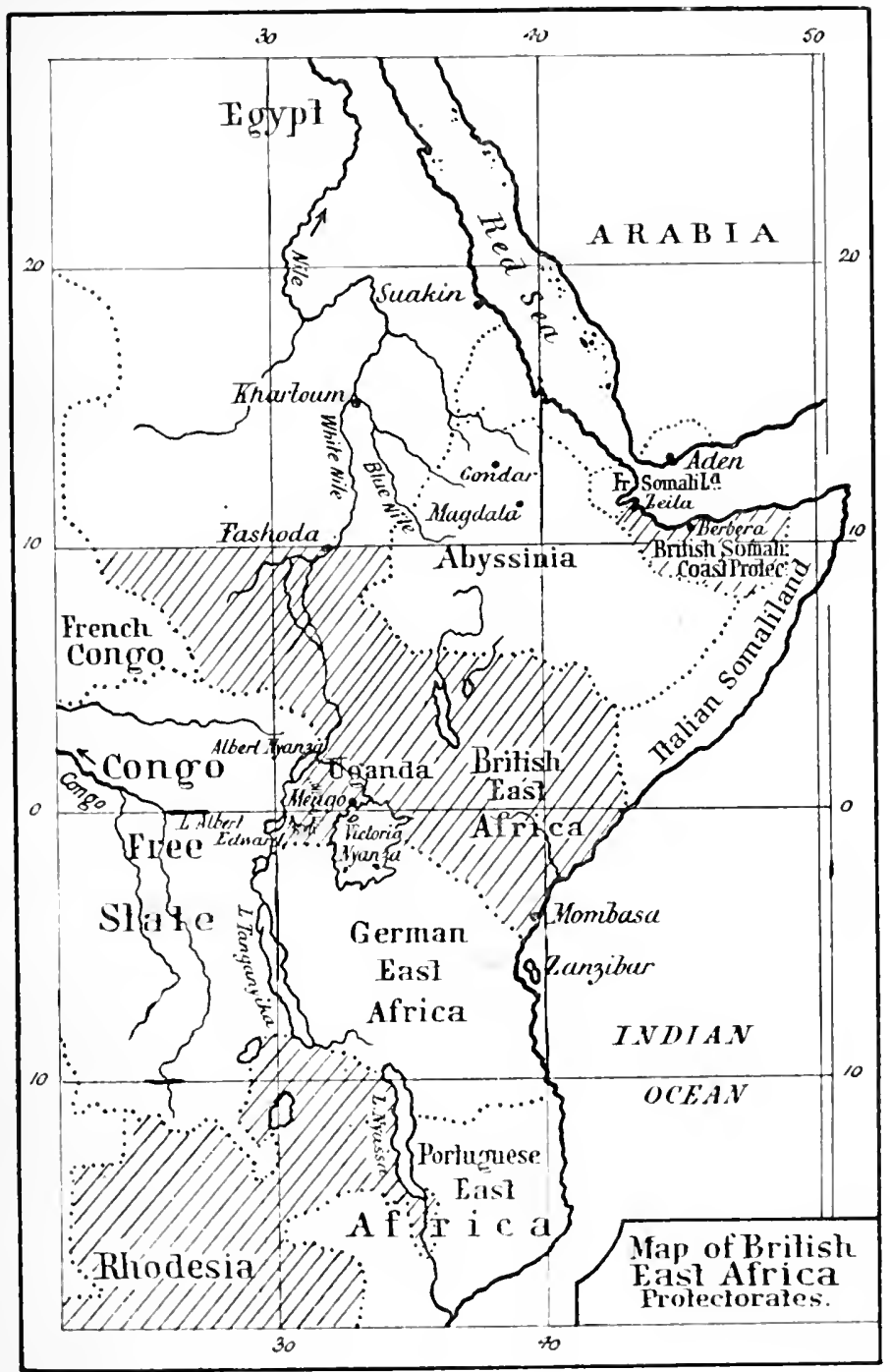

[To firce 1. 200. 
was paid to native chiefs for the forts and factories oceupied; trade alone was the raison d'étre of these settlements, and there was no sovereignty or ownership in the European communities there. The English and the Dutch settlements were so mixed up that no line of demarcation or fronticrs marking spheres of influence could possibly be drawn. The English had their headquarters at Cape Coast Castle, and the Duteh had theirs at St. George D'Elmina, only a few miles away. The Dutch settlements wore not a success, and they cost Holland some $£ 11,000$ yearly. Britisl trade, too, suffered under sueh circumstances, so that both countries were anxious to make some readjustment.

In 1867, therefore, an Anglo-Dutch Convention was signed, by which Holland ceded to England all her settlements on the eastern half of the Gold Coast, and England Dutch ceded to Holland all hers on the western half. Cessions. The results were not satisfactory. The natives would not recognise the transference of protection, and the Dutch had to defend themselves from the attacks of the Fintees, and other tribes. In 1871, therefore, Holland made another Convention with Great liritain, by which she sold her stores and other assets to England at a valuation, and with. drew entirely from this Gold Coast, where she had been settled for 235 years.

This cission of the Duteh settlements, however, involved England in unforeseen trouble. The hinterland was occupied by some powerful kings, who were not only Ashantl War, frequently at war with each other, but who
1874. resented the transfer of Fimina to a protector strong enough, should it choose, to discontinue paying the "ground rent," and to prevent access from the sen to the interior via Elmina. The Ashanti king seized some Europeans and imprisoned them at Kumasi, and refused to give them up. War therefore brolie out. In January, 187t, 
Sir Garnet Wolseley invaded Ashanti territory, and after twice defeating the enemy, entered Kumasi, and burned the town, from which the ling had fled. A treaty was then concluded, by which the Ashantis renounced all clains on the Protectorate, and agreed to pay an indemnity, and put a stop to human sacrifices.

This breaking up of the power of Ashanti was all important. for the safety of the British Protectorate; but the Treaty of 1574 was not carried out by the Ashantis, and the hinterland remained a terror to the British traders. Wars and murders continued, and the Ashanti king, Prempeh, refused to recognise the authority of the governor of the Gold Coast. In 1895, therefore, another expedition was organised and sent against. Ashanti under Sir Francis Scott. In January, 1896, Kumasi was again occupied, and the king being captured was taken as a prisoner and lodged in Elmina jail. In was in this expedition that Prince Henry of Battenberg lost his life through ferer. Refractory and rebellious conduct on the part of the Ashantis necessitated another expedition in 1900 . Colonel Willcocks was sent to relieve some missionaries and other Europeans who were beleagured in the fort of Kumasi. After accomplishing his object with complete success Colonel Willcocks further quelled the insurgent spirit throughout the country, and in 1901 peace was once more restored. In September of that year Ashanti was annexed by Great Britain.

There was something comical about the scramble for Africu, which began in the 'eighties; for from that time chartered companies were formed, there was a rush to make treaties with the natives, and "spheres of influence" were beingr announced, protectorates proclaimed, and annexations declared, by most of the great colonising powers of Europe. Lagos had been acquired by Great Britain as far back as 1861, and things jogged along quictly enough for about a quarter of a century. But when France begin exploring the Sahara, and claiming 
to "protect" Westorn Africa from the Mediterranean to Timbuetoo, and from 'Timbuctoo to Dahomey on the west of Lilgos, and when, in addition, the Germans seizerl the Canneroons on the east, Great Britain replied by declaring a Protectorate over the Lower Niger. Prolonged and troublesome nerotiations with France and Germany ensued, but at length the boundaries were satisfactorily settled-with Ciernany by the treaties of 1585 and 1893, and with France by agreenents of 1890 and 1898. The National Africa Company' which had been founded in 1879 received a charter in 1896, and then beeame known as the Royal Niger Company. On January 1, 1900, the Crown took over the territores of the Company, and Nigeria is now administered by the Colonial Oftice, being divided into Upper Nigeria and Lower Nigeria, with a High commissioner over each.

The Transyaal and the Orange Riyer Colony.-After the Great Trek of 1836, and the foundation of the Orange Free State and the 'lransval Republic (already mentioned), there was pratically no centril government in those States. Both States were extremely denoeratic in their organisation-if such a word as organisation can be applied to them at all. Indeed, in the Orange Free State, every man did as seemed right in his own eyes. Whether these eolonists could shake off their British allegiance, possess thenselves of the hinterlanel, and establish independent republies, was a rery most question of constitutional law. So dangerous and intolerable was the situation, indeed, that, in 1848, a British gilrison was placed in Blocmfontein, and the country was declared annexed by England. Howerer, by the Sand River Convention in 1852, the independence of the Transval was reeognised; the garrison was then withdrawn from the Orunge lree State, and the independence of that eountry also was recognised (1854). The practical legalisation of sliwery, and the conse- 
quent irritation of and hostilities with the natives, was the chief cause of the trouble between the Boers and Great Britain, which the following years developel.

In 1856, something in the shape of a constitution was tramed in the Transvaal, providing for a triennial Volksraad (or parliament), together with a president and a council. The first president was Commandant-General M. W. Pretorius. But not all the petty district states, into which the country had hitherto been divided, would recognise the new Constitution. Both Zoutspansberg and Lydenburg repudiated it entirely, and the Transvaal was threatened with a civil war. The situation was complicated by an effort, at first friendly, and then forcible, to effect a union with the Orange Free State; and it was not until 1860 that Zoutspansberg and Lydenburg gave in their submission to the majority, and became incorporated with the Transvaal. Pretoria was now made the capital of the Republic and the seat of goremment.

The seventeen years which followed this consummation, however, were far from happy or reassuring. Native risings and Kaffir wars, consequent on the continuance of slavery and a slave trade, as well as repeated efforts to appropriate fresh territory beyond the frontiers, alternated with intestine quarrels and civil war. The education of children was neglected, missionary work was much restricted, the treasury was empty, the introduction of paper money did not sare the situation, and the public credit sank very low: On the north the Kaffirs were threatening, and on the east the Zulus. The discovery of gold and diamonds on the western frontiers caused further boundary disputes in 1867. A three-cornered claim npon a diamond mine near what is now called Barkly West, on the banlss of the Vaal, culminated in an arbitration, which found in the favour of the Griquas, a race of halfcastes, to whom the strip of territory was accordingly handed 
over. This was known as the "Keate Award," from the name of the referee, Lieutenant-Governor Keate of Natal. This award was followed by the voluntary submission of Griqualand West, so-ealled to distinguish it from Griqualind East, which lies south-west of Natal. This award, with its sequel, was far from being acceptable to the Boers.

In 1872, Pretorius resigned, and the Rev. T. F. Burgers, a minister of the Duteh Reformed Church, was elected l'resident. Burgers was an active and well-intentioned man, but with somewhat romantic ideas. The old troubles continued-border wars with the natives, slavery cruelties, want of funds, and loss of public credit. The paper money had become so depreciated that the one-pound notes were worth no more than a slilling. Burgers himself was in despair, and so bitterly disappointed with the croolied and refractory character of the people who had chosen him as their President, that in the Volksriad (in March, 1877) he indulged in some very plain language to his countrymen: "I would rather," he declared, "be a policeman under a strong government than the President of such a State. It is you-you members of the Raad and Boers-who have lost the country, who have sold your independence for a drink. You have ill-treated the natives, you have shot them down, you have sold them into slavery, and now you have to pay the penalty. . . . We should delude ourselves by entertaining the hope that matters would mend by-and-by."

The penalty here spoken of referred to the approaching annexation of the Transvaal by Great Jritain; for the danger

Annexation of and disorganisation seemed to the British 1877.

gorernment so great, that it sent out Sir Theophilus shepstone to enquire into the feasibility of amexation. In April, 1877, Shepstone issued a proclamation declaring the Transwal amnexed. The whole question bristled with difticulties, and it seems clear now that 
Shepstone was misled into beliering that the majority of the 3oers were in favour of annexation. Some 33 per cent. of the adult male population did indeed petition for annexation, but nearly twice that proportion was against the measure, most of them, probably, most violently opposed to it. The action of the British government was no doubt hastened by rumours of a Transvaal-German alliance, or of intervention on the part of Germany.

In 1879, Sir Owen Lanyon was sent out as Governor of the Transvaal. This selection was not a happy one. Lancon was quite ignorant of the Boers and their language, and seemed unable to accommodate himself to their ultra. democratic ways. As governor, he received $\$ 300$ a year "coffee money," for which he was expected to drink coffee occasionally with the people. This, however, he did not do. And this ignoring of national customs, this nonconformity on the part of the governor, bred fresh discontent among the people, and petitions for independence were got up, and a deputation was sent to England with the same object.

Meanwhile, the Zulus, after inflicting a disastrous blow upon the British armies at Isaudhlwana, were defeated, and their power brolien by Lord Chelmsford at Ulundi, while another great menace of the Transraal, Secocoeni, was routed by Sir Gamet Wolesley, and his army dispersed. This British intervention and annexation was prompted by a desire for obler and peace, and not from any particularly sclfish motive; for as yet the great gold mines had not been discovered, and the Transvaal presented no particular attraction to the emigrant.

Disraeli's parliament was drawing to a close, and Mr. Gladstone's election specches implied threats that, if successful at the polls, he would rescind the annexation proclamation. The spirit of our Constitution, however, strongly discourages the reversal by one ministry of the acts of its predecessol's; 
and the reactionary threats of an opposition statesman are thus bound to be largely modified after his accession to oflice. The Boer appeals to Mr. Gladstone to fulfil his Midlothian pledges and cancel the annexation, were replied to by him to tha effect that the freedom desired by the Boers might be "most easily and promptly conceded to the Transval as a member of a South African Federation." This was far from satisfying the agitators, and the independence moverpent in the Transval grew daily in extent and intensity,

The rigour with which Sir Owen Lanyon enforced the payment of taxes, including the seizure of the property of those who were in arrear, did not ease the

Boer War of 1880. situation, and the smouldering fire broke out into rebellion in the same year (1880). Then followed, in rapid succession, a series of slimishes and combats wholly disastrous to the British arms. At Bronkhorst Spruit a British detachment was surprised and cut up, about balf being killed and the rest made prisoner:. At Lang's Nek, in Natal, a hill which the Boers had occupied, Sir George Colley was defeated in an attempt to dislodge the enemy. He then occupied Majuba Hill, which commanded the camp of the Boers. Here he was attacked, on February 27 th, and lost nearly half his force in killed and wounded, and was himself among the slain.

After Colley's death, General Sir Evelyn Wood succeeded to the command, but, to the surprise of everybody, a treaty was almost at once concluded with the Boers, Retrocession by which the latter were to enjoy all the of Transyaal, independence that was compatible with British
1881. suzerainty and a British resident at Pretoria. In May, 1881, this treaty was matured into the Convention of Pretoria. By this Convention (which consisted of 33 artieles), "the control of the external relations of the said State, including the conclusion of treaties and the conduct 
of diplomatic intercourse with foreign powers," and the right to march troops, if necessary, through the territories of the Transvaal, were retained by Great Britain. Mr. Kruger was now President, and remained President for eighteen years. The Boers began at once to use their independence in a peculiar way; they adopted the monopoly system, which had been the cause of such trouble between our own sovereigns and the nation in the time of Elizabeth and the Stuarts, and which had been abolished by the Long Parliannent. Thus, the Transvaal government granted concessions or monopolies to private persons, of such things as alcohol, dynamite, jam, bricks, wool, paper, etc.

Frontier quarrels, too, revived. The Boers of the southwestern district burst across the border, drove back the natives, and set up the "Republics" of Stellaland and Goshen, situated in what is now British Bechuanaland. The colonials pro. tested, but the Boers continued their operations; and, further, began raiding into Zululand on the east, and into the Chartered Company's territory on the north. To check these raids, it was found necessary to send out a force, under Sir Charles Warren, and to organise a frontier police force to provide against future contingencies. Sir Charles Warren succeeded in exterminating the two republics, and occupying that part of Bechuanaland withont any fighting.

Mr. Kruger, at the same time, headed a deputation to London, to interview the Colonial Secretary, with a view to modifying the Convention of Pretoria in the direction of according the Boers more freedom in their foreign relations, and, if possible, to dispensing with the objectionable word "suzerainty." The deputation was so far successful that the Pretoria Convention of 1881 was superseded by the London Convention of 1884. By this latter Convention, the Transvaal boundaries were once more defined, the title of the Boer State was changed to the "South African Republic," a veto over 


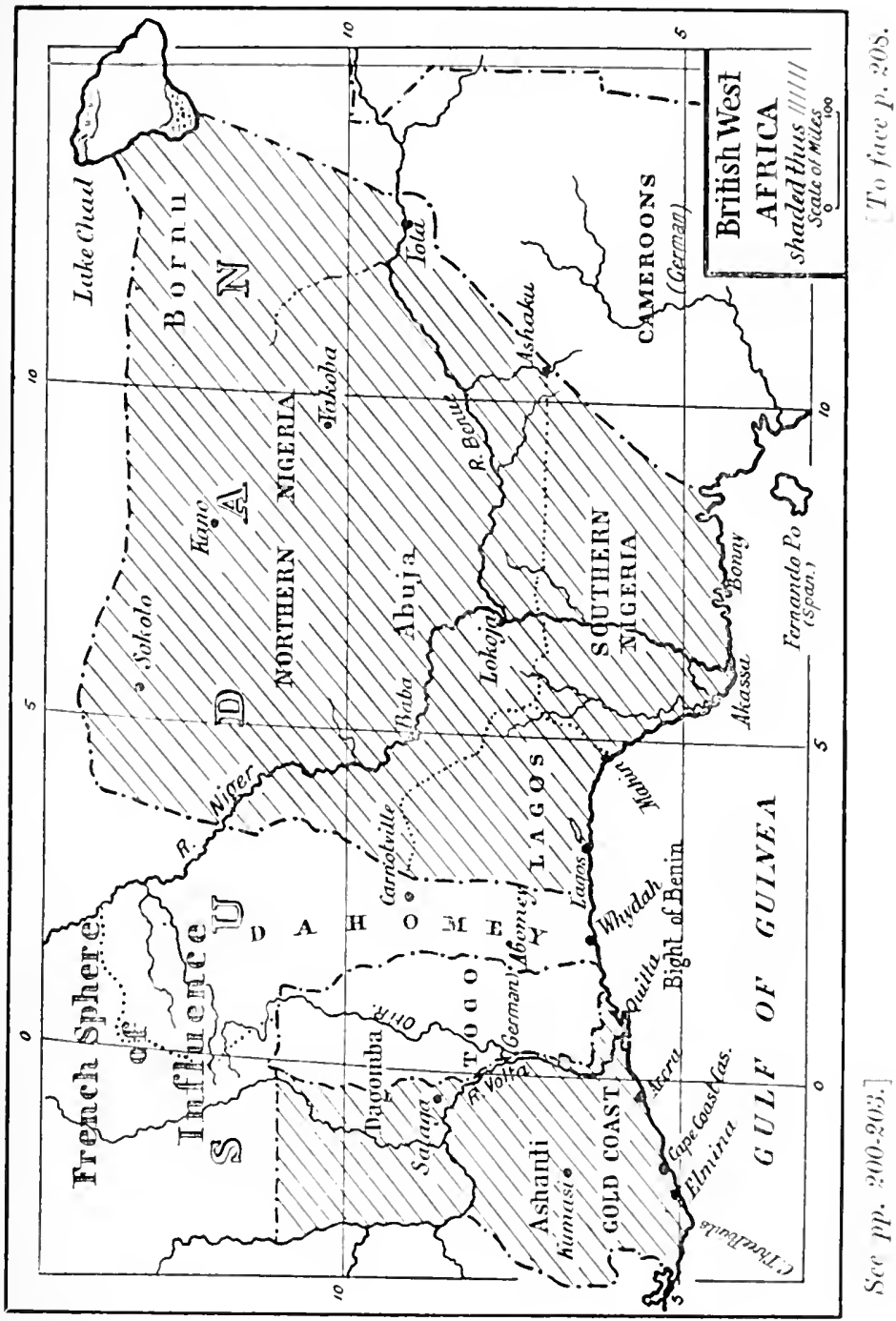



the foreign polities of the Republic was still reserved to the 3ritish government, and though the word "suzerainty" was not used, it was claimed by Lord Derby (the Colonial Secretary) that the thing was not relinquished. Following on this convention, in 1885, the Boers entered Zululand, and, by intrigue or negotiation, claimed a large amount of territory, and called it the "New Republic" ; which annexation, though in considerably reduced dimensions, was recognised by Great Britain in 1886, and was incorporated in the Trans. vaal in 1888 .

In 1886, came the great crisis in the history of the Republic. Gold had been found there before this time, but it was in 1886 Johannesburg. that the Rand Gold Fields were discovered, which soon turned out to be perhaps the greatest in the world. Their value has been estimated at $£ 700,000,000$. The whole country, and with it the political situation, was at once transformed. A rush from almost every European country, as well as from America, took place. The land increased in value by leaps and bounds. Villages and hamlets swelled into towns, and the city of Johannesburg sprang into existence. Soon the Boers had sold about one-third of their Iand to the immigrants-or "Uitlanders," as the settlers came to be called. This influx of foreigners travelled chiefly by way of Natal, and gare that country, and to its cities Durban and Pietermaritzburg, an enormous stimulus. Owing to the elaborate and expensive machinery required to work the deep Transvaal mines, the miners were not exactly of he same character as those of California, Australia and Flondzke; the " were to a considerable extent men of substance vitl long pockets; and though bogus companies were started, the number of needy exploiters, unscrupulous adventurers and other undesirables was not large. This industrial "boom" brought about also a financial revolution, for the wational revenue increased with unprecedented rapidity. In 1882, the revenue 
was $£ 177,030$ : in 1887 , it was $£ 1,500,000$, while in 1899 it was $£ 4,000,000$.

And now began that great struggle between the Transvaal government and the Uitlanders, which resulted first in the

\section{The Uitianders.}

Jameson Raid, and secondly in the war of 1899 and the final conquest and annexation of the country by Great Britain. If the Uitlanders were not the usual riff-raff of fortune-seekers, their ways and mannews were not exactly those of the Boers; and it must be confessed that by introducing into the country many of the vices without any of the virtues of civilisation, they gave the Dutch rustics cause for a great deal of well-founded and natural irritation. Many of the Boer farmers were simple, unsophisticated men, religious, Bible-reading folk, desiring to live quiet lives, with traditions of Brille and Leyden circulating in their system; it is not to be wondered at that they should be scandalised at seeing a great city rise up suddenly in their midst, filled with drinkingshops and gambling-dens, and patronising horse-racing, betting and Sunday theatres. The indefinite growth and permanent domicile in their midst of this pattern of civilisation was naturally most repulsive to all quiet, homely and morally-given minds; and it is only by surrendering one's self to a blind and bigoted partisanship that we ean ascribe to one side alone all the blame and responsibility in the struggle that followed. At all events, every impartial person will allow that the Boers had something more than a pretext for the revenge which they proceeded to take on the foreigners of Johannesburg. Seeing Johannesburg assuming alarming proportions in population as well as "civilisation," the government at Pretoria proceeded to crush the life out of the alien community by a long series of oppressive enactments.

Though paying seven-eighths of the revenue, these Uitlanders were deprived of the franchise, neither had they any roice in 
the choice of State officials, whose salaries, at the same time, rose prodigiously. In 1886 , those salaries totalled only

Penal Laws. $£ 51,000$ a year; in 1899 , they anounted to $£ 1,200,000$, while bribery, shameless and corrupt, was carried on at Pretoria. Nor was the situation eased as time went on. The residential qualification for the franchise when granted, was raised from five years to ten, and from ten to fourteen. On the education of the children of the Uitlanders $£ 650$ was spent yearly; on the children of the Boers the yearly sum expended was $£ 63,000$. The municipal government of Johannesburg was out of date as well as corrupt. Sanitary science was a thing unknown. There was no proper drainage system and no adequate water supply. The impartiality of the police could not be depended on, and justice was tainted by national prejudice. The Uitlanders could not sit on a jury. The mining interests were being constantly hampered by fresh restrictions. The railways were owned by the state, and the rates and fares charged were exorbitant. The numerous duties and tolls paid by the residents of Johannesburg were not expended for the benefit of the town, but were pocketed by the government at Pretoria. Add to this that the Uitlanders were actually commancleered for compulsory military service, and perhaps the limit of the unreasonable was reached, though the cup was not yet full.

It is not to be wondered at that under these cireumstances petitions were addressed first to the goverment at Pretoria without effect, and then to the government of Queen Victoria, and that threats of intervention had to be resorted to before a few of the worst grievances werc mitigated.

As the British government did not see its way to intervene or put further pressure on the government at Pretoria, it is hardly to be wondered at that, amongst British sympathisers 
in adjacent teritory, som anoficial attempt should have been made to compel the Boer govermment to redress the grievances of the Uitlanders.

On November 15th, 1895, the British Bechuanaland Police were disbanded, but, being allowed to join the Chartered

Jameson Raid. Company, many of them did so. Drilling and recruiting was carried on at Mafeking and Pitsani, in British Bechuanaland, near the Transraal frontier. Between these places and Johannesburg relays of horses, stores and provisions were established, and other preparations made for a military expedition. The "Raid" was engineered by Dr. Jameson, Administrator of the British South Africa Company, and with him were associated many other officers. On the expedition being announced to the men, however, some of them demurred, and demanded to know if they were marching under the Queen's orders, or under those of the Compans. The officers replied that they were going to fight for the supremacy of the British flag in South Africa, that there would probably be no fighting, but that they would be ready if attacked. Rumonrs of the Raid having reached head. quarters, letters and telegrams were sent after Dr. Jameson by the Governor of Cape Colony, Sir Hercules Robinson, commanding the expedition to return at once, and stating that Her Majesty's government repudiated the whole proceeding. The expedition, nevertheless, proceeded into the Transvaal. But, on January 1st and 2nd, 1896, they were attacked by the Boers, and overpowered; and after some fighting and loss of life, the expedition surrendered. On being tried at Pretoria, four of the leaders were condemned to death. On this occasion the Boer government sent to Cook House Drift for a beam upon which, in 1816, five Boers had been hanged by the Cape Town authorities for a rising in connection with some slarery outrages. That severity, though eighty years old, had not been forgotten. The vengeance of 
the battle-field, as Sir Conan Doyle remarks, may be forgiven, but not that of the gallows. The sentence on the Jameson raiders, however, was not carried ont; it was commuted to a fine of $£ 25,000$ each inflicted on the leaders, while the rest of the officers were sentenced to two years' imprisonment and $\& 2,000$ fine each. This sentence was, after a short imprisonment, commuted. This treatment, it must be owned, was, on the whole, not only unierengeful, but generous. A bill was subsequently sent in to the British government by the Pretoria authorities, amounting to $\mathscr{L} 1,677,93 \mathrm{~s} 3 \mathrm{~s}$. $3 \mathrm{~d}$. This, however, has not yet been paid, not even the 3s. 3d.!

Further Boer Commissions were appointed to enquire into the grievanees of the Uitlanders, and Reports were duly issued advocating reforms; but the Reports, as before, were ignored, and the tyranny continued, and was, indeed, augmented. The Uitlanders then in despair sent a petition direct to Queen Victoria (1899) signed by 21,000 persons, enmmerating their grievances, and praying for intervention. In consequence of this petition, negotiations followed at Bloemfontein between Sir Alfred Milner and President Kruger. But it was inpossible to obtain any reasonable redress from the latter. The negotiations dragged on without any progress being made, while the British government massed troops on the Natal frontier of the Transvaal, and sent out reinforements. The erisis grew darker and more threatening every day. The Boer government now repudiated the British suzerainty altogether, on the ground that it had not been mentioned in the Treaty of London of 1884, which amended the Pretoria Convention of 1881. Mr. Chamberlain pointed out that if everything in the earlier convention was to be taken as cancelled because it was not mentioned in the later treaty, this cancelling would include the grant of self-government to the Transval. The Bocrs offered to submit the whole dispute to arbitration, but such a course could not be adopted by Great Jiritain, unless she was 
prepared to reeognise the South African Republic as on an equality with herself.

At last the Boer gorernment, on October 9th, sent in an ultimatum demanding that the troops on the Natal frontier, and also the reinforeements sent to British South Africa since January 1st, 1899, should be withdiawn, that those on their way out be sent back without landing, and that all outstanding disputes should be submitted to arbitration. A reply was required within forty-eight hours. The British govern ment replied that it was impossible to discuss such terms at all. On Wednesday, therefore, October 11th, 1899, war broke out between England and the South African Republic; the Orange Frec State joined the Republic, and thus became involved in the war.

It is evident now that both the belligerents in this war belittled their opponents unworthily. The Boers, after witmessing Lang's Nek, Ingogo, and Majuba

South African Hill, and more recently, the Jameson Raid, War, 1899-1902. viewed with supreme contempt the capabilities of the British Army; and the English people, or a considerable majority of them, looked upon these bandoliered farmers as beneath contempt; and burning to wipe out the many rebuffs their troops had suffered, and to avenge the Uitlanders for the long and systematie tyranny they had endured, believed that the British army "would move like a stcam-roller from Cape Town to Pretoria," erushing all opposition and annihilating it once for all.

The Boers began by invading Natal, and advancing towards Cape Colony, and it was with no less surprise than chagrin that the English publie read shortly afterwards of four British forces being shut up or paralysed by the Boers-at Kimberley, Mafeking, Magersfontein and Ladysmith. The first part of the war consisted in the struggles of the British lion to extricate limself from these spring-traps in which his paws were held 
fast. Lord Methuen failed to relieve Kimberley, and was rudely checked at Magersfontein where General Wauchope was killed and nearly 1,000 oficers and men lost. General Gatacre, in attacking the Boer position at Stormberg about the same time, was badly beaten, and lost over 700 killed and wounded. Sir Redvers Buller, who had arrived as Commander-in-Chief, could do no better. His efforts to relieve Ladysmith were a disastrous failure. The Boers under General Botha had fortified themselves on the north bank of the Tugela River, and General Buller's assault on their position was repulsed with the loss of 1,100 men and ten guns!

Lord Roberts was then appointed Commander-in-Chief, with Lord Kitehener as his Chief of the Staff. The Boers,

anxious to reduce Ladysmith before Lord Roberts arrived, made a desperate assault upon the town, but they were repulsed with severe loss (January 6th, 1900). General Buller then made another attempt to reach Ladysmith by erossing the Tugela and turning the enemies' left wing. This attempt, known as the Battle of Spion Kop, was more disastrous than the previous one, and General Buller had to recross the Tugela with the loss of 1,700 men (January 24th). A third attempt at relief made on February 5th, fared no better. The deadlock continued, Mafeking, Kimberley and Ladysmith being invested by the Boers, and the British forces locked up in those towns being able to do nothing but hold their own. Lord Roberts, however, had arrived and already organised a foree, with which he proceeded to the Modder River on the western border of the Orange Free State. General French was sent immediately to the relief of Kimberley, which he effeeted in dashing style at the head of his cavalry. The Boer General, Cronje, retreated to Paardeberg where he was forthwith hemmed in by Lord Kitchener and General French, and obliged to eapitulate with 
4,000 of his men. This success, which ras only gained, however, at considerable loss to the British, took place on February 27th, the anniversary of Majuba Hill. On the following day, General Buller had succeeded, after another ten days' struggle, in relieving Ladysmith, Lord Dundonald and the Natal Carabineers entering the town on February 28th. General Buller's four efforts had cost the army 5,000 men in all.

Lord Roberts then occupied Bloemfontein, the Orange Free State capital; and a fortnight later Piet Joubert, the Boer Commandant General, died at Pretoria. Lord Roberts' army was not able to advance from Bloemfontein for another six weeks. Mafeking, which had been gallantly defended by Colonel Baden-Powell and his garrison since October 13th, 1899, was relieved by a flying column under Mahon (May 17th, 1900). The Orange Free State was formally annexed by Lord Roberts, who then pushed on to the Transvaal, entering Johannesburg (May 31st), and Pretoria (June 5th), and released some 3,000 British prisoners of war. President Kruger had already fled from his capital, carrying the State archives and the exchequer with him. Later in the year he abandoned his countrymen, and took refuge in Portuguese territory, whence he sailed soon afterwards for Europe (October, 1900). On September 1st, 1900, the Transvaal was declared annexed by Great Britain.

As with the occupation of the two capitals the war seemed over, Lord Roberts left for England in December, and handed

\section{Guerilla War.} over the supreme command to Lord Kitchener. The very long limes of communication, however, between the British army an 1 Durban, on the one hand, and Cape Town on the other, presented many weak points, and offered an excellent opening for guerilla operations, which the Boers were not slow to take advantage of. In these tactics the Boers proved themselves expcrts of the first class, and 
there followed eighteen months of lreary invertebrate warfare, in which the Boers often succeeded in cutting the railways and telegraph lines, capturing isolated outposts, ambushing convoys and doing all sorts of miscellaneous clamage. They never concentrated for a battle, and being mounted they were almost invariably able to escape on the approach of an organised army.

De Wet attempted an invasion of Cape Colony (February, 1901), but being defeated at Philipstown and elsewhere, he had to retreat with the loss of several guns and many prisoners. Botha in like manner attempted to invade Natal, but met with a similar disaster. Nevertheless, the galling guerilla tactics lasted a year and a half, and it was not until Lord Kitchener had established concentration camps and a block-house system to protect the railways, and outmancurred the enemy by a series of "drives," that the Boers gave up the game.

In May, 1902, Generals De Wet, Botha, De la Rey and others, at Vereeniging, opened negotiations with Lords Milner and Kitchener at Pretoria; and peace was Peace of signed on the 31st of the same month. By Yereenising, this peace the Boers were to surrender un.
1902. conditionally, and become subjects of King Edward VII. The property of the Boers was to be restored to them, and an amnesty granted to all who had been engaged in "legitimate acts of war." $£ 3,000,000$ was to be given as compensation to those Boers whose farms had been sacrificed for the purpose of the concentration camps. The Duteh language was to be used in the schools and in the law courts where necessary, and self-government was to be introduced as soon as the country was sufficiently settled. The British losses were about 5,700 killed, and nearly 23,000 wouncled; while the Boers lost nearly 4,000 lilled, and nearly 40,000 prisoners, out of a total force of some 65,000 . 
In December, 1906, the Transvaal was granted a Constitution and self-government, in the form of a Legislative Council of fifteen members elected by the Responsible Governor, and a Legislative Assembly of sixtyGovernment. nine members elected by all white male British subjects over twenty-one years of age. The Legislature is elected for five years at a time, but may be dismissed by the Governor. The Executive resides in the minsters, who are appointed by the Governor. The population of the Transvaal was, at the Census of 1904, about $1 \frac{1}{4}$ millions, 300,000 of whom were whites, the rest being Kaffirs and other natives.

The Orange River Colony (the new title of Orange Free State) received a somewhat similar constitution in 1907, the Legislative Assembly consisting of thirty-eight members, and the Legislative Council of eleven. 
CHAPTER VIII.

\section{- \\ Miscellaneous Acquisitions.}

Sarawak and British Borneo.-The Dutch, since the begin. ning of the seventeenth century, had trading stations in Borneo, which they abandoned and retook again from time to time.

In 1841, Sir James Brooke, who had settled in the island of Labuan and at Sarawak in IVest Borneo, was by the Sultan appointed Rajah, and Sarawak was incorporated with the British Empire. By various treaties with the Sultan of Brunei (North Borneo), Rajah Brooke's territory was greatly enlarged, until it amounted to about 50,000 square miles.

- Rajah Brooke had much trouble with pirates and freebooters, but he held his own and managed his territory admirably until 1868, when he died, and was succeeled by his nephew, Charles Johnson Brooke (the present Rajah).

In 1881, the British North Borneo Company was formed and chartered. It claims jurisdiction over about 31,000 square miles in the north of the island.

In 1885, North Borneo, together with Sarawals, was proclaimed a British protectorate.

Cyprus.-After the Russo-Turkish War of 1877-1875, an Anglo-Turkish agreement was made (June 4th, 1878), by which England undertook to protect Asiatic Turkey against any future encroachments by Russia, and Cyprus was assigned to England, "to euable her to make necessary provision for 


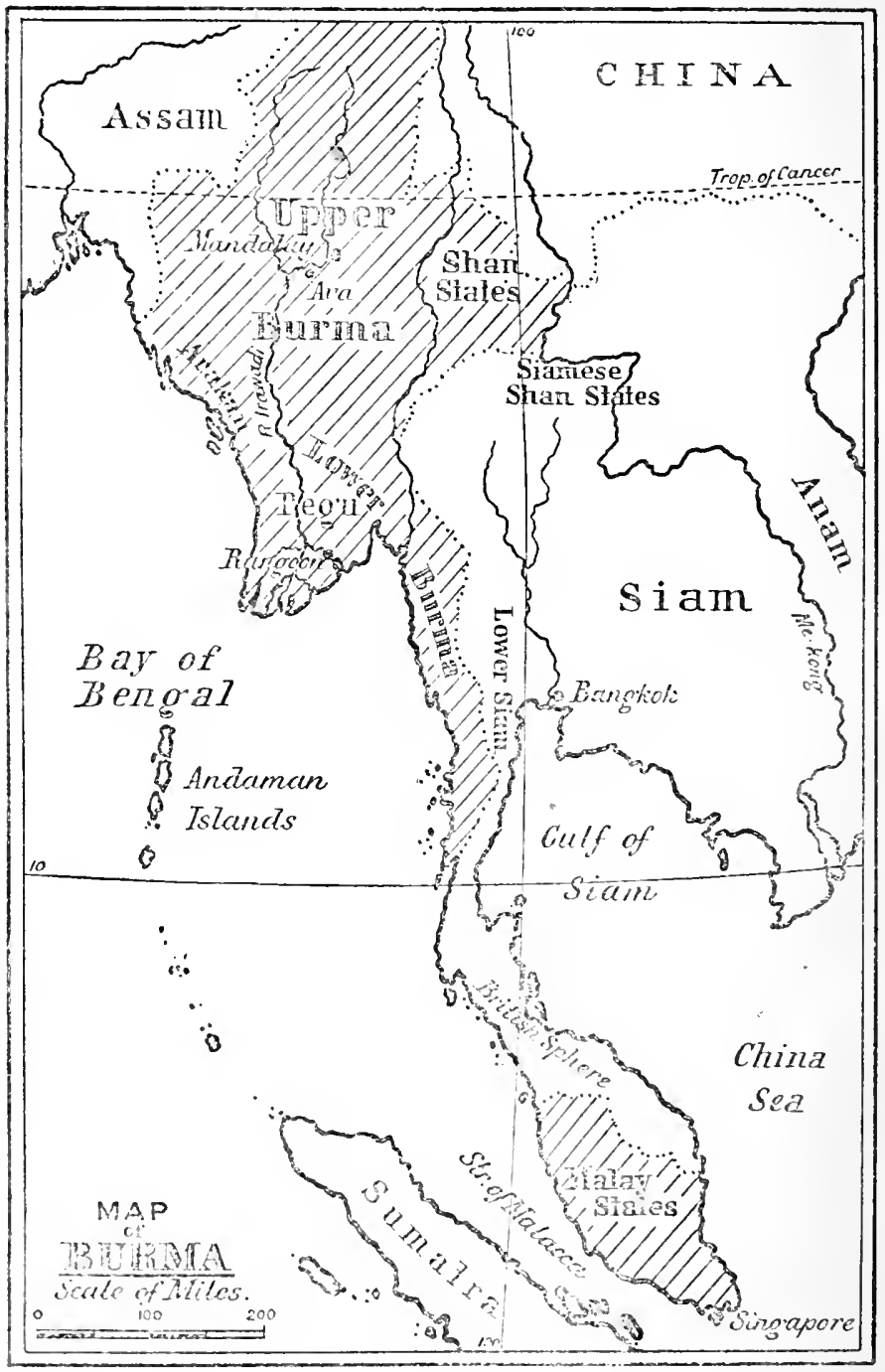


executing her engagement." Cyprus still forms part of the Ottoman Enpire, and it must be restored by England if ever Russia should restore Batoum and Kars to Turkey (!).

Burma.-By the Treaty of Yandabu (1826), after the first Burmese War, Burma ceded to England Assun, Tenasserim, and part of Aracan, and agreed to receive a British resident.

In 1851, the violence of the native governor of Rangoou proroked another war with the British, after which Pegu was annexed. This war did not terminate until 1853, when the ling of Ava submitted, and threw open the navigation of the Irawadi.

In 1862, British Burma (Lower Barma) was formed into a British province.

The relations between the native and the British gorernments were stramed for some time. In 1878, King Thebaw succeeded King Mindon. He was an almost irreclaimable savage, and inaugurated his reign by massacring a large number of his own relatives. The British resident withdrew, his life being in danger, and diplomatic relations became more strained than ever. The government of the country went from bad to worse, and soon the outlying districts were beyond control, full of lawlessness and violence, and a standing danger to the British provinces. The Anglo-Burmese treaties were broken by King Thebaw, who dealt in monopolies, and thereby demoralised trade. Not only was the Indian government unrepresented in Burma, but French and Italian representatives were encouraged and treated with. There was further trouble over the Bombay-Burma Trading Company, which Thebaw threatened with fines and confiscations.

In 1885, therefore, an ultimatum was sent to the King, and, an unsatisfactory reply being given, General Prendergast was sent into the country with British fores. The Burmese were taken entirely by surprise. The Brtish army entered Mandalay, and Thebaw, being captured, was leposed and 

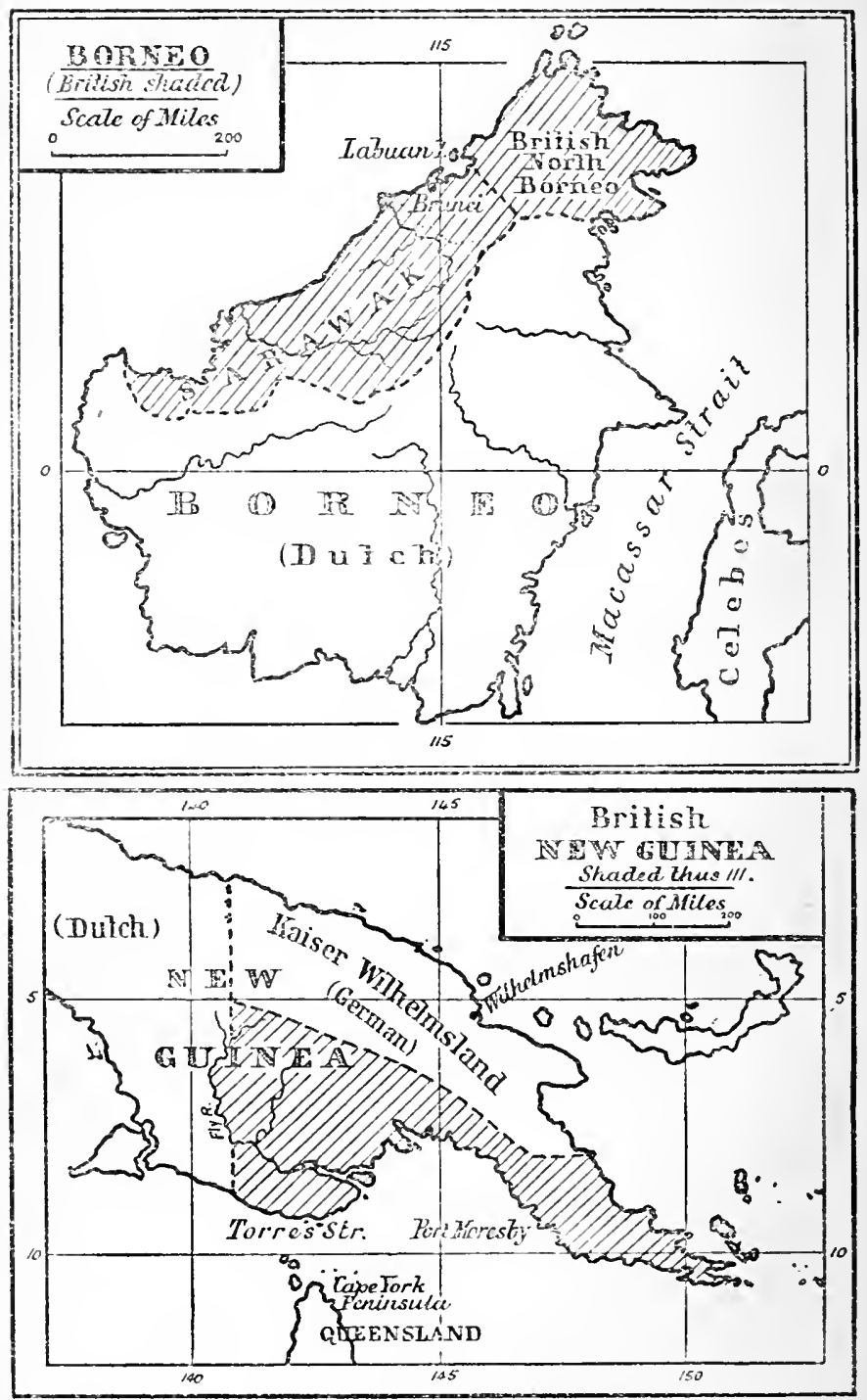
deported to India. Upper Burma was then annexed (1886). The country was still full of disbanded native soldiers and deserters, who roamed about, plundering and inurdering everywhere. The suppression of these Dacoits necessitated several further expeditions, an it was several years before peace and order were restored.

New Guinea.-Papua, or New Guinea, was visited by Alfied Russell Wallace in 1858. Later on, Captain Moresby explored portions of the country (1874), and his name is perpetuated in the chief town, Port Moresby. The Dutch had ancient claims on Nerv Guinea, and the Germans were beginning to settle in the island; so that (as in the ease of Aden and Somaliland), the Australian authorities became troubled as to the future of the great island dominating their northern coast and of the fine water-way called Torres Strait. Queensland therefore, in 1883, declared the eastern part of New Guinea annexed. This annexation was disallowed by the British govermment. In the following year, however, Great Britain declared a protectorate over Now Guinea east of longitude $141^{\circ}$, including the islands. In 1884, Germany set up a trading company on the north-east coast, and soon afterwards annexed the same. Great Britain and Germany then agreed to partition the eastern half of the island, the northern moiety (called Wilhelm Kaiser's Land) being taken by Germany, and the southern being retained by England. The western half of the island was left to the Dutch, who had had interests there of long standing.

British New Guinea comprises about 90,000 square miles, with a population of less than half a million, which includes a mere handful of Europeans. In 1895, the Anglo-Dutch boundaries were settled by treaty, but the Dutch occupation is hardly yet an effective one. English, Dutch, and German missionaries have long been labouring, and with some suceess, to undermine the savagery of the natives and supersede it by Christian influences. 
Fiji.-The Fiji Islands were discovered by the Dutch narigator Tasman in the seventeenth century. In 1859, the King and his chiefs offered themselves and the islands to the British government, but the offer was not accepted. Thanks to the missionaries, however, the savagery of the natives was being rapidly exterminated, and, with a luxuriant soil, fertile country, and friendly islanders, British emigration thither began to flow in a steady stream; whən, therefore, in 1874, another and unconditional cession of the islands was made to Great Britain, the offer was accepted. When Queen Victoria ascended the throne there was not a Christian in Fiji; when she died there was not a pagan there.

Weihaiwei.-In consequence of Chinese fanaticism, resulting in the murder of European missionaries in 1897, several European nations, including France, Russia, and Germany, secured leases of Chinese ports for ninety-nine years. Great Britain, at the same time, obtained a ninety-nine years' lease of Weihaiwei, on the coast of Shantung, nearly opposite Port Arthur.

About the same time, a portion of the mainland of China, opposite the north coast of Hong Kong (together with a number of islands in the vicinity) -was ceded to Great Britain, to be administered by the authorities of Hong Kong.

Heligoland, which was taken by the British from the Danes in 1807, was, in 1888, havded over by Great Britain to Germany (in exchange for certain rights in Zanzibar), and, in 1890, it was incorporated in the German Empire. 


\section{APPENDIX I.}

\section{$\longrightarrow 0-$ \\ Biographical.}

Baker, Sir Samuel White (1821-1893), was a native of Worcestershire. After much travelling and exploration in Asia (especially in Ceylon), he set out for Africa, an l, after navigating a large portion of the Nile, he succecdel, in 186.t, in diseovering the Albert Nyanza. He published several books on his Cingalese and his African exploriations.

Brooke, Sir James-"Rajah Brooks"-(1803-1858), was a native of 13ath. Entering the service of the list India Compiasy, he fought in the first Burmese war (1823). In 18:33, he visitel Chinit, and elerishing th: project of elcaring the Malay Arclipelaso of pirates, he went to Borneo, and helped the Sultin to subdue the freelmoters of Simawh. For this service it was that he was male Rajah of sarawit, in 1shl. Ife aceonplis ed great thiugs (with the help of otier officers) in exterminating piricy and violence in those waters. In $1 \leq 17$, he returned to England, and was highly honoured, and made Governor of the bsland of Libuan, which had been bount fro'n the Sultan. Exeessive severities in the further suppression of pirtcy caused the home government to deprive him of his governor hip. He died in Devonshire, at Burrator, on an estate presented to him by public subseription.

Chatham, William Pitt, Earl of (1708-1778).--William Pitt, the elder, ranks among the greatest of British orators and statesmen. On leavin: Oxford he enterel the army, and it was as a cornet of the Blues that he first entered Parliament as member for Ol] sirum. The part he played in opposing Walpole led to the loss of his commission. After this he becanto one of the most actire of that minister's opnonents, leadin: the younger part of the Opposition--"The Boys"-with such spirit and effect as to earn for himself a great reputation as a Parliamentary debater. In 1ift, be became one of the vice-treasurers for lreland, and was subsequently appointed Pitymaster-General. In 1751, he becime ehief minister, hort was soon onsted by his great rival Fox. In 1756, however, the King hat to yield to the popular acelaim, and Pitt again became elnief ministur, only to resign his post when the King arbitrarily dismissed his friend an 1 relation, Lord Temple, from his post of First Lord of the Admiralty. For two and a half months the country remained without a IInistry, ant at the expiration of that time, the King was forced again to send for Pitt, under whose able rule the reign of George II. clesed in a blaze of glory, in striking contrast to the bitter humiliation of the periol which immediately preceded it. The aceession of George III., however, brought Lord Bute into power, and Pitt again resigned. Once more the voies of the nation recalled him, in $176 i$, and lie ayin took onice, accepting, at the same time, the title of Farl of Chathm. Ill-hoalth maliel him to withiraw from all active participation in the govermment, and is is during this period that, under his lieutenant, Tuwnshend, those measures were passed which led to the separation of the American eolonies. In 1770 , he returned to active life, speaking as beiore, but with little of his 
old power. In 1778 , the excitement of a speech against the recognition of the independence of the American colonies proved too great for him. He fell in a fit on the floor of the House, and died about a month afterwards.

Cliye, Robert, Baron Clive of Plassey (1725-1774), was the foremost of those great "soldier-politicals" who won England her Indian Empire. Enlisting as a clerk in the East India Compauy's service, he was sent to Madras at the time when the tension between the English and French in the Karnatik was at its height. He sprang into sudden fame by his daring capture and glorious defence of Arcot. Clive's work in India falls into three periods: the Conquest of the Karnatik, beginning with the Siege of Arcot; the Subjugation of Bengal, beginning with the Battle of Plassey; and the Reorganisation of the civil and military administration of India, which followed his return from Engiand in 1765, as Governor of Bengal. The latter part of his career earned him bitter enemies, and, largely as a result of their machinations, he was, on his final return to England in 1767, charged in Parliament with peculation and fraud. The House of Commons refused to pronounce him guilty, but the strain brought on a state of melancholia, in which he died by his own hand.

Cook, Captain James (17:8-1779), was horw in Yorkshire. He entered the Navy, and served unter. Wolfe at the taking of Quebec in 1759 . He was made licutenant in due conrse, and began his famous voyages in 1768, visiting Australia, and returning to England in 1771. His second voyage was to New Zealand. In a third voyage he discorered the Sandwich Islunds, 1776; and explored the western coasts of Nortl America. At Owhyhee he was murdered by the natives before he could reach his boat. Starting life with a poor education, he finished by being elected a Fellow of the Proyal Society.

Cromwell, Oliver (Lord Frotector) (1593-1658), ranks among the greatest of Englishmen, as a general, a statesunan, a diplomatist and a ruler. He not only took a prominent part in the defeat of the Royalist party, but succeeded in overawing the Parliament and establishing a military oligarchy. His foreign policy aided greatly in the foundation of the British Empire abroad. He was the first to take advantage of Britain's maritime power to attack an enemy in her colonies, and the policy thus inaugurated did more than add Jamaica to the British Crown; it was the beginning of the development of the British Empire. Indirectly, too, his policy, as embodied in the Navigation Act, for the extension of British commerce, tended in the same direction since it transferred much of the great Dutch carrying trade to England, and thus sent her ships into every sea.

Drake, Sir Francis (1515-1595), was the chief of those Elizabethan seamen who laid the foundation of English maritime greatness. His early life was snent under the tutelage of that other famous seaman--his kinsman, Sir Johu Hawkins, with whom he made various voyares to the Spanish Americas. In 1570, he, as a privateer, captured Nombre de Dios, and crossing the Isthmus of Panama, gained his first glimpse of the Pacific, and vowed that he would never rest until he had, God willing, "sailed an En lish ship in those seas." In 1577, he sailed through the Straits of Magellan-lundered the Spanish forts on the Pacific coasts, and captured 
galleon after galleon, and then sailing westward, completed the circumnavigntion of the globe-an exploit for which klizabeth knighted him and later milie him Vice-Almirnl of Englnd. In the litter capncity, he rentered signnl servico ngainst the Armad:t. The siminrits lech his name in the greatest dread, punningly dubing him fil lracontr the Jragon). He died at sea, in 1595, and was buried of Porto Bello.

Frere, Sir Henry Bartle (1815-84), entered the service of the Last Indin Company, 18:33. IIe filled severnl posts in India, nnd sueeeded Sir C'harles Napier ns Chief Commissioner of sindh. He did rnluable service in the Intiny by his infuence orer the natives. From 1462 to 1407 he was Governor of Bombny, and further distinguished himself $n \mathrm{~s} n \mathrm{n}$ administrator. He returned to England, and in 1872 , he went to Zanzibar, and suceeeled in mitignting the slave trinde in those parts. In 1577, he was made Governor of Cape Colony and High Commissioner for Sonth Afriea. Under his rigime took place the Kaffir and Zulu wars. Ilis poliey towards the Zulus, however, dit not aif to his reputation. One oljeet for which he had been sent to Africa-the federation of the South Afriean Coloniesiniled, nnd sir Bartle was recalled in $\mathrm{I}=80$.

Froblsher, Martin (d. 1594), was the first Englishman to attempt the diseovery - of a North. West pasage to China (Cathay). lle nreanised three voyages in nll, but with little practical result. He believed that he had found raluable deposits of gold in Northern Labrador, and hoped to found a settlement there-n hope which, like that of diseovering the North-West passage, was doomed to disappointment. He was knighted for the signal services he rendered in the defeat of the Armadia. In 1591 , he led a naval expedition to Brittany in aid of IIcnry $1 \mathrm{~V}$. of France, nnd was there wounded. He died on horrd bis ship, in Plymouth Sound.

Hastings, Warren (1732-1818), was perhaps the most famous of the many great Governors-Genernl of India. Htis early career was spent in the serviee of "John Company," where he speedily rose to distinetion, becoming, in 1757, resilent at Murshirabad. He retired to England in 1764, on a pension, but through losses was eompelled to apply to the Company for is 10 st-a request readily granted. He returned to India in 1769 as Resilent at Madrns, and on the passing of the Regulating Aet of 1773, beeame the flist Governol-General of India. IIis eareer was $n$ brilliant one, his rule suecessful, and he may be hed to have established the dominion of the Company on a firm nnd endrring bnsis. Certain of the mensures to which he was compelled to resort, through inaderuate support, were highly reprehensible, nnd on his return to Englund he was inpeached before the Lords. A trinl, extending over seven yenrs, ented in the refusnl of the Ifouse to eonviet him, but eost him his whole fortune. The Company, mindful of his great serviees, eame to his nssintance again nnd nsain. In his old age a peerage was offerd him. He refused to necept it unless it wns coupled with a publie reparation, which was, however, denied. While the charges brought agninst hin were, in the main, verified, it must be remembered that the course he ndopteil saved the English power in India, that his aceusers were lnrgely netunted by spite, and that his personnl integrity was ncver in question.

Hayelock, Sir Henry (1795-1857, was one of the nost illustrious of the great soldiers, to whose hravery and devotion the British Empire in India is due. Proeceding to India in 1823 , he won golden opinions by his courago 
and skill during the troublous prriod of settlement which preceded the Iutiny. His power as a linguist, too, was remarkable, and he proved himself in addition a military historian of no mean merit with his "History of the Ava Campaigns " and "Narrative of the Afgh in Campaign," throughout both of which he served, as he did also through the Sikh war of 1815 . His name is, however, chiefly associated with the relief and subsequent defence of Lucknow during the Mutiny. With some 2,000 men he marched day after day under the burning Indian sun, defeated the rebels in eight pitched battles, captnred 203 pieces of cannon, re-took Cawnpore, and finally threw himself into Lucknow, releved the little garrison and he:d the place until sir Colin Camplell was able to finally defeat the mutinous Sepoys. He died of dysentery a few dars after his work was compleied.

Hawkins, Sir John (1520-1595), was one of the foremost of the adventurers and merchant mariners of Elizathan times. He mate many royages to Africa and to the West Indies, was appointed Treasurer of the Navy and served as Rear-Admiral, with brilliant success, a ainst the Armada. To him belongs the infamy of being the first to engage in the "slave trace" between Africa and America, by pureliasing negroes in Guinea and selling them in Hispaniola. His last expedition was undertaken to rescue his son Richard, a captire among the Spaniards in the West Indie . Its failure left him broken-hearted, an he aied off Porto Rico in 1595.

Kruger, Stephanus J Paul (1825-190\%), was born at Rastenburg, and went with the great Trek to the Transval in $\mathbf{1 8 3 5}$. He began life as a farmer, went in for polities, 1872, under President Burgers, and visited England in 1877 and 1878, to protest against ammexation. He became President of the Transvaal 1882, but alandoned his country during the war of 1899-1902, and died in Switzerland.

Livingstone, Dayld (1813-1873) began life in a factory in Glasgow, where he managed to study medicine and theologs at the same time. In 1810, he went as a missionary to Africa, and laboured amongst the Bechuanis. In 1849 , he began his exploving expeditions, and succeeded in verifying the existence of Lake Ngami. During the next six years he explored a great deal of South Africa, and returning to England, he published a narrative of his missionary travels. Setting out again in 1858, he explored a great part of the Zambesi country, and visited Lake Nyassa. In 1865, he undertook another expedition to explore Lake Tanganyika. Here he was lost sight of for two years, but was found by Stanley at Ujiji, November, 1871. He was in a deplorable condition, having been robbed and deserted by his attendants. In his letters home, Livingstone spoke of the sollee of the Nile as being about 600 miles south of Victoria Nyanz?. In 1873, this illustrious exploier and evangelist died of dysentery at Ilala, in Central Africa. His remains were taken to England and buried in Westminster Abbey.

Macdonald, Sir John Alexander (1815-1891), son of IIugh Macdonald, of Kingston, Canada. He became a lawger, and practised at the bar of Upper Canada in 1835. In 1811, he became a Member of the Canadian Parliament, representing Kingston from that ycar nutil 1878. In 1854, he became Attorney General for Upper Canada, and in 1862, he became Prime Minister. He was a strong adrocate of the union of British North America, and when the Dominion became an accomplished fact, Sir John was made the flrst Dominion Premier. In 1871, he took part in the negotiatious 
with the Unitci states on the sulject of the Mlahuna chims. Fe had much to do with the construction of the Canadian lncite lanilway, and Canada owes a large amonnt of her suceess to his great amministrutivo talents.

Mackay, Alexander M. (1849-1890). - The story of Mackay is one of the nost remarkable of Christian romances. A young seotsman of very food cduciotion amb remarkahle talents, he give up the prospeet of a brillinnt careur as a mechnical engineer, and offerel himself for unissionary work. In 18.5 appeared Stanley's Ietter in The Inily Telograph (er' Staniey) describing Lganda and its kiug, aud calling upon Christian bugland to send missionaries to that nttractive and promising comrtry. It was in response 10 this appeal that Mackay went out, in compuny with severa] other's, under the auspiees of the Chureh Missionary Socicty, in 1676 . Various ealamities robbed Minekay of his collengues, and finally he was left alone in Uganda. There, besides prenching the Gospel and eivilising large numbers of natives, he taught the people to earpenter, print, huild, and do all sorts of mechanieal work; by which he won, first, their contidence, and then their admiration, ani, funally, their affection. The king, Mtesa, was, however, with many gool quilities, a treacherous charater; the Mlohummelan slave dealers were active; persecntions were set on foot; many of Maekay's converts were murdered, and his own life was frequently in danger. Stanley, on his Emin Relief Expedition, visited Uganda in 1\&89, and paid a high tribute to Maekay's heroism, and presset the young Scotsman to return to England with him. Mackny, however, preferred to remain at his post, and a few months later he fell a rietim to zeal, self-sacrifice and duty.

Moffat, Robert (1795-1883), was born at Inverkeithing, and laboured as a missionary, first at Erromanga, Namaqualand, and Bechuanaland, translating the whole Bible into Bechuana. His daughter married Livingstone, with whom, in his travels, she encountered freat dangers and suffered many hardships. Motrat did great things in opening up and Christianising large portions of routh Africa.

Nelson, Horatio, Viscount (1758-1805), one of the greatest, if not the grentest, of English seamen, did much, by his trimplus over the French and Spanish tleets, to lireak the sehemes of France and lunstrate her hopes of regrining that position in the East from whieh the genias of Clive and Waren Hastings had ousted her. 1[c carly distinguished himself in the Mediterranean under Jervis, and was made Rear-Admiral for his signal services in the battle of Cape St. Vineent. His greatest vietories were those of the Nile, Copenhitgen and Trafalgar. The tirst of these frus. trated Napoleon's plans arainst India, the seeond prevented a maritime alliance of the Northem Powers against England, and the last destroyed the French and spanish fleets, broke their power on the sea and rid Fngland of the fear of the threatened French invasion. Trafalgar, however, cost Englind her hero, who died in the moment of victory.

Park, Mungo (1771-1E06, hailed from near selkirk in scotland. His first calling was that of a ship's surgeon, which hrought him to the Fast lndies. Then he was employed by the Alrican Soeiety to explore th. Niger: but having reached that liver, and explored it for a consideralle distanee, he was obliged to retrace his steps, owing to daneers and privaions (1796). Jater on, he took charge of another expedition to the same region, but, no news having been heard of hirn lor a long time, a rescue party was sent 
after him, only to find that Park and his party had been murdered by the natives at Boussa.

Raleigh, Sir Walter (1552-1618, achiercd fame alike as soluier, courtier, historian, poet and adventurer. He served with high distinction in Ireland, and against the Armada, but it is as adventurer and settler that he is chiefly famous. He shared his half-brother's-Sir Humphry Gilhertsearch for the North-West passage, and succeded him in his endeavour to colonise the coasts of North America, and finally made various attempts to found a settlement in the Virginia, attempts which were at last crowned by success. In 1595 , he sailed to Guiana in search of El Dorado (the "Golden City"). At the accession of James I,, be fell into disfavour, was imprisoned for participation in the Main plot, and only released to undertake the search of gold, deposits of which he stated he knew of in Guiana. The quest was unsucessful, the party came into conflict with the Spaniards, and Raleigh, on his return, was executed, to appease the wrath of the Spanish Ambassador.

Rhodes, Rt. Hon. Cecil John (1853-1902, was the son of a Hertfordshire vicar, and was born in 1853. Being threatened with consumption while young, he was, on the adrice of a physician, sent to South Africa. Returning to England in a couple of years, he visited his physician again. The doctor had forgotten all about his case; on turning up his books, be said, "Why, you ought to have been dead two years ago!" Mr. Rhodes matriculated at Oriel College, Oxford, but lung trouble again drove him to South Africa, and settling with his brother at Kimberley, he went in for diamond speculations, incested in mines, and succeeded in amassing a large fortune. Having taken his degree at Oxford, and further entered as a Law student in the Inner Temple, he again returned to Sonth Africa, and began to mature vast schemes for the expansion of the British possessions in that country. Eutering the Cape Parliament as member for Barkly WVest, he was sent soon afterwards to arrange the delimitation of Griqualand West, when he obtained the cession of a large section of Bechuanaland; and as the government at the Cape refused to take this territory over, Mr. Rhodes induced the home government to establish a protectorate over the same (1881). A sort of duel now began b tween Mr. Rhodes and President Kruger, who had similar expansion schemes in view for his Transvaal Republic; and Mr. Rhodes, being appointed Deputy Commissioner for Bechuanaland, succeeded in frustrating Mr. Kruger's ambitions in that part of South Africa. The amalgamation of the various diamond mine companies into the De Beers Consolidated Mines has already been mentioned as the work of Mr. Rhodes. Mr. Ribodes's real ambition was to see the whole of Africa south of the Zambesi brought under British rule, but as he could not get either the Cape administration or the home government to follow him in his plans, he determined to form a company and obtain a charter which could deal with whatever territory it might be able to secure. Having accomplished this, he was instrumental in concluding with the Matabele King, Lobengula, the Moffat Treaty, which practically secured to the British (rovermment the "first refusal" or pre-emption over Matabeleland teritories. Thus arose the Chartered Company, which soon began to administer nearly a million square miles, and included Rhodesia (i.e., Mashonaland and Matabeleland), Bechuanaland, and British Central Africa. 
In 1890, Mr. Rhodes hecame Prime Minister in the Chpe govermment, but in 159.3 he hat to deal with .Iatabule disturbances, and some llyhting oceured botore poace was restored by the death of lobengula, in Is)l. In 1894, Mr. Rholes was made a privy Councillon, and labured hard for a general federation of British Sonth Afrie:t. llis connection with the Iameson Ifild calsed him to resign the premiership, as will as his directornte of the churtered Company. Loss of British prestige, in cont sequenee of the Ratd, eaused another Matizbele rising, uni numbers of the native police joined the rebels, and carried their arms with them. Mr. Inhodes orgmined a military force at Salisbury, which defeated the Matabeles at Gwelo. It was after this (in Ingh) that Mr. Rhodes paid his fitnous visit to the native chiefs in the Matoppo Hil's.

Mr. Rhodes was severely censurel by the Select Committee nppointed to incluire into the Jameson Raid for his conduct in regard to the same, which (said the Report) "inrolved him in grave brenches of duty to those to whom he owed allegiance." In the discnssions over this Report, however, Mrr. Chamberlsin sajd, "Although Mr. Rhodes had committed as great a fault as a statesman could commit, nothing had been proven, ind there existed nothing against his personal character as a man of honour."

Mr. Rhodes sat again in the Cape Parliament, and, heading the Progressire party, alvocated, more or less, a poliey of Free Trale, $c$ m. putsory education, railway extension, and the restricted sale of alcohol to the natives, not forgetting the fecteral policy-which has since been consummated. In 1898, Mr. Rhodes wis unanimously reelected a director of the Chartered Company, and from thenceforth he deroted his energies to the development of Rhodesia. One of his great schemes was the construction of a railway from the Cape to Cairo, in the interests of which he hal two interviews with the Cerman Emperor. In 1899, Oxford University eonfered the honorary degree of D.C.L. upon Mr. Rhodes, on whieh occasion he received an enthusiastic ovation. During the South Afrien War, Mr. Rhodes was shut up in Kimberley, and sustained the tension of the siege. After the raising of the siege by General French, Mr. lihodes repaired to Cape Town. He survived to see the practical destruction of the South African Republic, and its anmextion by Great Britain, but his health was broken, and he died on March with, 1902. He was buried, according to his own directions, in the Mfatiabele stronghold, in the heart of the Matoppo Hills. Mis will was a remarkabie one, Ite was never married, and he left most of his enormous fortune for the foundation of scholarships at Oxford, for students from the British eolonies, and from the United States of Ameriea; his objeet being expressed to be the unification, not only of the British Empire, but of English-spenking people throughout the world. A codicil to the will extended a number of scholarships to German students. Mr. Rhodes was, without doubt, one of the greatest of Empircbuilders, n min who "thought imperially," and whose name will for ever be assueiated with the expansion of the British Empire, the devotion to which was his passion and his pride.

8peke, John Hanning (1827-1861), came from Somersetshire. IIe served under Sir Colin Camploll in India, am endeavoured to explore the Himalaras and Tibet. Afterwards he visited Africa, in company with Captain 13urton, and, in 1959. diseovered the Victoria Nyunz. In 1860, he went (aceom. panied ly Grant) to ascertain the source of the Nile; and, practically succeeding in his object, his name became famons. Ife met his death by accident at B:th, being' shot by his own gun. 
Stanley, Sir Henry Morton (1811-199٪.-John Rowlands spent ten sears of his childhood in the Poor-honse of St. Asaph. At the age of fitteen he sailed, as a cabin hoy, to New Orleans. He was there adopted by a merchant named Stanley, whose names he took instead of his own. After taking part in the American Civil WVar, he was sent, in 1867, to Abyssinia with the British army as correspondent of The New Fork Herald. In 1870, he was sent by the proprietor of the same paper to find Lisingstone, which he suceeded in doing, in November, 1871, and, in 1872, he returned to England with Livingstone's diary. He was ererywhere received with acclamations, and honours and rewards were showered upon him. In 1874 , he was again sent to Africa, and explored the Victoria Nyanza. This lake, which it took him eight dass to circumnavigate, and whose area he found to be 40,000 square miles, he ascertained to be the chief somrce of the Nile. He further explored the Alhert $\mathrm{N}$ ranza and the country of Uganda, and it was a letter from Stanley to The Daily Telegraph that led to the sending, by the Church Missionary Socicty, of the mission to that conutry, which erentually led to the proclamation of the British protectorate of Uganda. He further explored the Congo, and returned rid St. Panl de Loanda. Stanley conducted other exploring expeditions through Africa in 1879 , 1882, and 1:87, when be relieved Emin Pasha, the Gorernor of Equatorial Africa, whom, with his followers, he brought safely to Egypt. On this journey Stanley dise vered Monnt Ruwenzori and Lake Albert Edward, the latter being prored to be the source of the White Nile. Stanley pullished many accounts of his travels, e.g., "How 1 Found Livingstone," "Tlirough the Dark Continent," "In Darkest Africa," etc.

Wellington, Arthur Wellesley, Duke of (1789-1852), was the great rival of Napoleon, whose schemes on land he foiled as completely as Nelson had done at sca. The earlier part of his career as a military commander was spent in India, where his brother-the Marquis Wellesley-was GovernorGeneral. He plased a prominent part in all the operations which led to the reduction of Mysore, and led the war against Sindhia, capturing Alrmednagar, and then totally defeating 50,000 Maratha troops in the famous battle of Assaye, in which he had, in his command, but 3,500 foot and 2,000 horse. A second great victory at Argaum scattered the Maráthás and led to the cession of a large territory to the East India Company. His chief fame, however, rests on his marvellous campaims in the Peninsula, and the crowning victory of Waterloo, which shattered Napoleon's hopes and sent him a prisoner to St. Helena. During his later life, he was a great figure in the political world, where, however, he was far less successful than in the field.

Wolfe, james (1727-1759), was one of the youngest of those leaders, whom Pitt's instinctive knowledge of men led him to select for the control of the Briti-h operations in the colonies. He first won fame in the colonies by his success in the expedition against Cape Breton, where the honours of the siege of Louisbourg, fell to his share. In 1759, he led the famous expedition against Quebec, then the keystone of French power in Canada, where his daring in scaling the reputed inaccessible Heights of Abraham, together with his skill as a commander, led to a complete victory. Wolfe died on the field, but five days later Quebec surrendered, and with it Canada passed into the possession of Britain. 


\section{APPENDIX 11. Epochs of Expansion.}

1588. The Defeat of the Armada,-This broke the Spanish supremacy upon the seas, and led England to endeavour to suceed her hotls in eommoree and colonisation. The movement in this direction was, however, ehecked hy the Stuarts, who had little sympathy with schemes for the development of Greater Britain, and were, moreover, allied, more or less elosels, with lrance-England's great rival in this attempt.

1607-1620. The Settlement of Amerlca.-With the settlement of Virginia hy sir Walter laleigh and of the New Fingland States by the Pilgrim Fathers and those who followed them, Greater Britain-that is, the British Empire beyond sens-came into existence.

1655. The Conquest of Jamaica.-This marked Cromwell's return to the poliey of Elizabethan times. He stw the allrantage of attaeking Britain's enemies in their colonies, and possesreal for the first time in the country's history a fleet capable of earying his poliey into exeeution. The navy, organised by Sir llirry Vane and Blate for the defence of the country a aniust attacks by sea, heeame a potent factor in the extension of the Empire. "The capture of Jamaiea was the first truits of the policy.

1651, The Nayigation Act.-This mensure was the onteome of Cromwell's desire to secure for Englant that position in the world's commerce which her insular eharacter, her powertul navs, and the repute of her seamen demanded. It led to a lone sea-duel with liolland, whieh ender in transferring the Duteh earryin trade to bughand aud made English merehants the most formidable rivals of the Dutch in the East.

1688. The Revolution.-The Revolution of I623 marks the beginning of a century of close alliance with Ilolland against Franee. Irouis XIV. determined to secure for France the commereinl supremacy which England had all but wrested from the Dutch. In consequence of the attitude of the home governments the relation between the traders of the two nations in India and America became hit erly liostile.

1713. The Treaty of Utrecht.-This practically fare Englind the commereial and maritime supremaey of the world. The Armadis saw her enter the competition, the Treaty of Utrecht saw her win it. $U_{p}$ to the defeat of the Armalia Spiain had been the first state in the world; from that time her power deelined. At the time of the Commonweatth Holland was the wealthiest country of the world. From 1660 to 17us, France had held the first place. The Treaty of litrecht gave it to England. England gained Acalia (Nova Seotia), one of France's three great settlements (Aeadia, Canada and Jouisiana) in North America, together with Newfoundland and Hudson Bay Terricory; Spain by the Assiento Contract was compelied to break the monopoly by which she had elosed Central and South Amerien to the trade of the world.

1763. The Treaty of Paris.-The Treaty of Paris mirkel the ellmination of English power in the eighteenth century. The whole of North Ameriea was seeured to her by the cession of Canada, while Clive's vietorics 
in India had practically crushed French hopes of Empire there, and had established the firm foundations of British rule. The Empire thus swayed by Britain, if smaller in extent than that of Spain, was rastly superior in importance.

1766. The Fall of the. Mogul Empire.-This threw India into a state of anarchy. The Imperial sway hitherto held by the Moguls having lost its power, the minor princes took up arms one against the other. The result was a condition of affairs highly favonrable to the rise of new powers. The conquest of India was due to the confusion and anarchy caused by the fall of the Moguls, the discovery of Dupleix -afterwards utilised by Clive - that the natives could be disciplined in the European fashion and were willing to place themselves under European officers. 'Thus the material for the Company's army lay ready to hand ; the cost was met by the riches captured. In this way India was made to supply the troops and defray the expense of its own conquest.

1775. The Amerlcan War of Independence.-The thirteen states which seceded to form the United States of America, were by far the greatest and most important part of Greater Britain. Moreover, their secession demonstrated the impossibility of forming an Empire on the lines hitherto accepted. It was argued that as soon as a colony had arrived at a certain pitch of development it would infallibly shake itself free from the mother country. The inference was justified while the colonies remained under the old system. The growth of the new Greater Britain has shown it to be false as regards the new colonial system. By the rupture with her American colonies England lost ber first Colonial Empire.

1815. The Battle of Waterloo.-The result of Waterloo was to free England from all danger of attack by Napoleon, whose schemes included the overthrow of British power in the East, the establishment in India of the French Empire dreamed of by Dupleix, and the wresting from England of the commercial supremacy she had held since the Peace of Utrecht.

1857. The Indian Mutiny.-This led to the final downfall of the power of the East India Company, which, in fact, may be really said to have ceased to exist when its monopoly of trade was withdrawn at the granting of its last charter in 1833. In the year following the Mutiny, the Company was abolished by Act of Parliament, after an existence of some two hundred and fifty jears, and British India was formally annexed to the British Crown.

18:4. Discovery of African Diamond and Gold Fields.-The explorations of Baker, Burton, Speke, Park, Livingstone, Moffatt and Stanley led Europeans and Americans to take a strong negative interest in Africa. The discovery of the diamond fields of Griqualand West, etc., and, above all, of the Transvaal gold fields in 1881, cansed Americans and Europeans to take a strong active interest in the "Dark Continent"; and very soon England, France, Germany, Portugal, Italy and Belgium were hurrying to "peg out" Africa; so that in about ten years after 1884 there was very little of the continent left unappropriated by European nations. In that decade Basutoland, Bechuanaland, Zululand, Rhodesia, British Central Africa, Nigeria, Zanzibar, Uganda, Somaliland and British East Africa were added to the British Empire. 


\section{APPENDIX III.}

\section{$-\mathrm{O}-$ \\ Glossary of Colonial Terms.}

Acadia.-The name applied to the tir b'ench settlements in North Anerica. It comprised, at first, Nova seotia, and then appears to have includel other districts oceupied by the Frencit.

Afrikander.-A native of Capo Co'ony of of the ncighbouring districts, lon of white parents. A deseemint of European settler's in sisuth Arical.

Boer. $-A$ deseendant of the Duteh settlers in South Alntea. (D., Whe - it (amer, a peasant.)

Buccaneers. -The mame given to those piratical adventurers who combinel to attack the Spanish possessions in America, darng the latter half of the seventeenti century.

Bund or Bond. - U U,iun of Dutch settlers in suth Africt.

Bushranger.-In Australian criminal, generally an escuped convict, who, taking to the woods, there led a predittory life.

Cathay. - The nume by which the Chinese Empire was known to nedieval barope.

Colony. A Aistriet inhabited by a number of people who hatre emigrated thither from their native land, and who remain subject to the home government. The etrliest colonies were probably funded by the Phoenicians on the islands or along the southern coasts of the Mediterancan, of whiel Carthage was the ehief.

Coolie.-The name given by Europeans in India to native labourers emaged in menial oecupations, and in Afriea, the West Indies, Sonth Ameriea and other plites to an East Indian or Chinese labourer employed, under contract, in plantation or otler work.

Creole. A native of the West Indies or Spanish Americi descended from linopean ancestors-a person born in these countries but of atree not intigenous to them.

Crown Colony.-1 colony in which the Crown has entire control of the legislation, while the administration is carried on by officers under the control of the hone government.

Dependency. - A territory subject to the control of Great Britain, although not forming an integral part of the Empire.

Drift - Boer word for furd.

El Dorado.-A country rich beyond all others, which the spanints believed to exist in the New Wordd. Orellanit avered that he hal foumd it on his voyage down the Amazon, 1510-I541.

Entrepôt. -A place used as a mart, to which goods are sent to be distributed over a country, or where goods are collected for export. E.J., Jlong liong is the freat entrepot lor Chinat.

Eurasian.-A Europern and Asiatic half-breed.

Factory.-An establishment of mereliants (or factors) in a foreign plate, Iormed for mutual protection and advantage aut oceuping speeial posts or depots also terned factories) often strongly furtuled. 'Tlet facturies of the Iludson's Bay Corupany were known as lorts. 
Galleon.-A large armed ship of burden. The name nsually applied to the huse unwieldy vessels use 1 by the spaniards for the transpo:t of treasure or troops.

Gurkhas.-The dominant race in the Hindn kingdom of Nepil.

Hinterland.-The inland country behind a coastal settlement or possession.

Hottentots. - A South African race, differing from the others in that its members are of a sellowish-brown complexion, of smaller stature, of ungainly build and of inferior mental powers. The name is imitatively descriptive of their speech, which contains a number of clucks, and so resembles stammering.

Kaffirs,-A South African race originally inhabiting Cape Colony, Natal, or the neighbouring districts. The name Faffir (or Kafir) means unbeliever, and was appied to these races by the IIohammedans of Eastern Africa becanse of their refusal to accept Mohammedanism (cf. Turkish Giaour.)

Jaaries or Maoris.-The aboriginal inhabitants of New Zealand. The word Maori means native or indigenous.

Maráthás.-A race of Western and Central India, which having conquered mans states, formed themselves into a confederation to resist the power of the Moguls.

North-West Passagie.-A route to China, India and the East, which early naristors believed to exist round the northern coasts of America. The efforts to discover the North-West passage, though unsuceessful, gave a rast impulse to maritime enterprise.

Pahekas. - The name apslied by the Maories to the white tralers who risited the islands.

Penal Settlement.-A settlement beyond seas, to which convicted prisoners are transportel for punishment. Port Jackson was such a settlement.

Plantation. - A settlement in a new country, where farming operations were carried on by white settlers, the labour being furnished by the natires of the country or by conricts and prisoners exported from the home country.

Priyateer.-An armed vessel, fitted out by private persons lut acting on a Government commission , letter of marque) to prey upon the commerce of a nation whth which it is at war.

Prospector.-One who explores or saarches for valuable minerals as a preliminary to commencing mining operations.

Sepoy.-A native sollier serving ia the Indian Army under the British Government. (The word sipahi meaus a horseman-a soldier.)

Sikhs.-A great religious sect of the Punjab, which organised itself into a powerful military force-the Khalsa. The word Sikh means a disciple. The sect was founded by Nanak Shah abont 1500 A.D. Their religion pa takes both of Hinduism and of Islam.

Spheres of Influence.-Those parts (chiefly of Africa) which are the scenes of trading or civilising activity on the part of the great European powers.

Squatter.-One who (a) settles on new land without a title; (b) (Australia) obtains from the government the right of pastnrage on moderate or nominal terms. The name is now extended to include all stock-owners.

Trek.-Originally to trarel by ox-waggon. The name is now usually applied to a migration such as that in which the Boers left Cape Colony to found the Trunsvaal (The Great Trek, 1835-1836).

Uitlander.-Foreigier. Foreign settler in the Transvaal.

Yeıd.-In Africa, a plain covered with very short grass. 


\section{INDEX.}

\section{$-0-$}

\begin{tabular}{|c|c|c|c|}
\hline & & & \\
\hline Slavery & fff $\mathrm{f}$ & ct & \\
\hline Acalia & ... & .• & 121 \\
\hline Acadians, Expulsion of & $\cdots$ & & $12=3$ \\
\hline $\begin{array}{l}\text { Afghan imbroglio } \ldots \\
\text { Afriea, British live in }\end{array}$ & $\begin{array}{l}\cdots \\
\ldots\end{array}$ & $\cdots$ & 155 \\
\hline gitation, the Conviet, & in & Calue & \\
\hline Colony . $\quad \ldots$ & ... & $\cdots$ & $13 ! 3$ \\
\hline Alambagh, The $\ldots$ & ... & & 86 \\
\hline Alaska Bomndary ... & $\cdots$ & .. & 139 \\
\hline $\begin{array}{l}\text { Allahithad, 'Treaty of } \\
\text { Aluboyma, Massacre of }\end{array}$ & $\cdots$ & & \\
\hline mboyna, British in & & & 108 \\
\hline gerican Colonies, Bri & itain & & \\
\hline
\end{tabular}

American Colonies, Britzin and the $\ldots$ Independenee, $\ldots$ charation of Amcricun Independence, iVar of Ancient Colonies ... $\quad . . \quad$.. An lo. French Struggle in Karnatik:lirst Phase $\ldots . \quad \ldots \quad \ldots 60$ second Phase $\quad \ldots . \quad \ldots \quad 61$ Third Phase... $\quad . .6 \quad \ldots .60$ Fourth Pliase $\quad \ldots \quad \ldots \quad 73$

$\begin{array}{llllll}\text { Antigua } & \ldots & \ldots & \ldots & \ldots & 1 \text { ls }\end{array}$ Arcot, Clive at $\quad \ldots \quad$... $\quad \ldots \quad 6$ $\begin{array}{lllll}\text { siege of } & \ldots & \ldots & \ldots & \text { (it }\end{array}$ $\begin{array}{lllll}\text { Asbantilvar } & \ldots & \ldots & \ldots & 201\end{array}$ $\begin{array}{llllll}\text { Australasia } & . . & \ldots & \ldots & \ldots & 15\end{array}$ Australia, Grest Strike in $\quad \ldots .175$

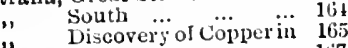
"1. Discovern or Copperin 1157 Australiau Colonies det ... ... 163 $\begin{array}{ccc}\text { Federation } & \ldots & 25,177 \\ \text { A ward, Keate, The } & \text {... } & \end{array}$ Barbadoes ... $\quad \ldots \quad$... $\quad \ldots \quad 144$ Basutoland ... $\quad . . \quad$... $\quad \ldots .199$ Bentinck-Governor-General of

\begin{tabular}{|c|c|c|c|c|c|}
\hline lundia & $\cdots$ & $\cdots$ & $\cdots$ & $\ldots$ & 81 \\
\hline Bermudas & ... & $\ldots$ & $\cdots$ & $\cdots$ & 119 \\
\hline Boer War & & $\cdots$ & $\cdots$ & $\cdots$ & 207 \\
\hline Borneo, Bri & itish & $\ldots$ & $\ldots$ & $\cdots$ & 219 \\
\hline Botany Bay & & & $\cdots$ & $\cdots$ & $\begin{array}{r}155 \\
33\end{array}$ \\
\hline $\begin{array}{l}\text { Bristol diel' } \\
\text { Buceaneers, }\end{array}$ & $\begin{array}{l}\text { chan } \\
\text { The }\end{array}$ & & $\cdots$ & ... & 4 \\
\hline & & in & &. & $4 i j$ \\
\hline $\begin{array}{l}\text { Bund, 'The } \\
\text { Bunker lli }\end{array}$ & & & $\cdots$ & $\cdots$ & 193 \\
\hline Bunker $11 \mathrm{i}$ & & o of & $\cdots$ & $\cdots$ & 0,16 \\
\hline & & $\cdots$ & $\cdots$ & $\cdots$ & \\
\hline
\end{tabular}

(P.ine. Burmese War, lirst $\quad \ldots \quad \ldots \quad \ldots l)$ " " $"$ se ond $\ldots$...

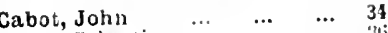

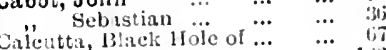

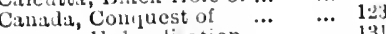

" Federalisation ... $\quad \ldots . .131$

$"$ and the states ... $\quad \ldots . .125$

" Revellion in $\quad . .6$...

" The Fulural plan $\ldots . .13 .3$

"̈rdians, Enolish and Fench 1:7

Caming Lord

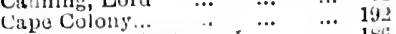

" . Capture of ...

C."iwnpor"e, Massitere of $\ldots . \quad \ldots$ s.

$\begin{array}{llllll}\text { Cetywayo } & \ldots & \ldots & \ldots & \ldots & 197\end{array}$

Clive, Aduinistration in Bengnl 71

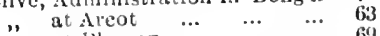

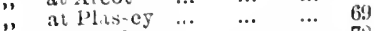

"1. $\begin{array}{lllll}\text { Trial of } & \ldots & \ldots & \ldots & 72\end{array}$

Cölonies, Anricultural and Plä. tittion ... $\quad \ldots . \quad \ldots \quad 15$

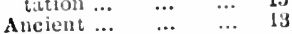

" Ansu-baxon, Charae[1. vi vi

british, Future of $\ldots .24$

" British, Vilue of ...

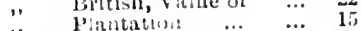

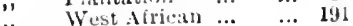

Colonisation, Growth of ... $\quad \ldots . .20$

$\begin{array}{lllll}" & \text { Mutleru } & \ldots & \ldots & \mathbf{1 1} \\ " & \text { Reasons for } & \ldots & 15\end{array}$

" liensons for syse 15

" bixclusive $\quad$... 20

1Viketield's System in Australia ... 161

Columbia, Briti-h ... … i.2, 1:3

"Company, John" $\quad$.. ... 55

Compun, The East India $\quad \ldots .5 \%$

Company, 'The East ludia and the Government $\quad \ldots \quad \ldots \quad 75$

Compiny, The East on lia, IIonopoly of 'lrate withilrawis ... 81

Cook, Capiain, in Austatla ... 155

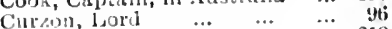

$\begin{array}{llllll}\text { Cyptus } & \ldots & \ldots & \ldots & \ldots & \mathbf{2 1 9}\end{array}$

Dalhousle, Lord $\ldots \quad \ldots \quad \ldots \quad 82$

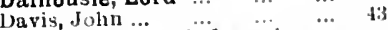

Declarati $m$ of 1 indepentence,

American $\quad \ldots \quad \ldots \quad \ldots \quad 11 \mathrm{~s}$ 
PAGE.

Delhi, Siege of $\quad \ldots \quad$... $\quad \ldots \quad \ldots \quad 89$

Diamond Mines of Kimberley

Dominion of Canala $\quad \ldots . \quad \ldots . \quad 131$

Dupleix in the Karnatik... $\quad \ldots .61$

East India Company $\quad \ldots \quad \ldots \quad 51$

Elgin, Lord ... $\quad \ldots \quad \ldots .89 .95,128$

Elizabethan seamen, The $\ldots$... 38

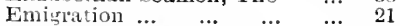

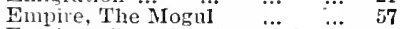

Empire's Growth, Phases of $\cdots, 28$

$\begin{array}{ccccc}\text { England and Franee } & \ldots & & 31,56 \\ ., & , \text { Holland } & . . & \ldots & 30\end{array}$ $\begin{array}{lllll}. & \text { " Holland } & \ldots & \ldots & 30 \\ , & \text { "Spain } & \ldots & \ldots & 29\end{array}$

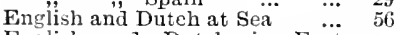

English and Dutch in East Indies $\ldots \quad \ldots . \quad \ldots \quad$... 52

English and Freneh in Ameriea 119

Exploration, Australian ... ... 160

Explorers, Austra!ian $\quad \ldots . \quad \ldots . \quad 159$

Federation, Australian $\quad 25,177$

Federalisation, South African ... 196

$\begin{array}{llll} & , \text { in Canada } & \ldots & 131\end{array}$

$\begin{array}{lllllll}\text { Fiji } \quad \ldots & \ldots & \ldots & \ldots & \ldots & 224\end{array}$

Freneh Designs in India...

Frenel, The, in America $\quad$... 119

., ", in the Karnatik ... 60

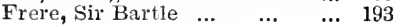

$\begin{array}{llllll}\text { Gambia } & \ldots & \ldots & \ldots & \ldots & 191\end{array}$

Georgia, Foundation of ... $\quad \ldots \quad 110$

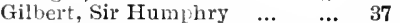

Gold, Discovery of, in Australia 161

Gold Coast Settlements ... $\quad . . . \quad 191$

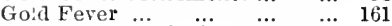

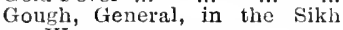

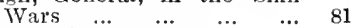

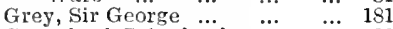

Growth of Colonisation ... $\quad . . .20$

Growth of the Empire, Phases

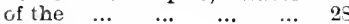

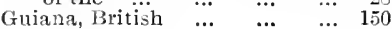

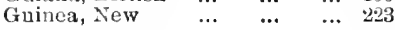

Haldar Ali ... $\quad \ldots \quad \ldots \quad \ldots \quad \ldots \quad 74$

Hastings, Varren ... $\quad . . \quad \ldots \quad$.. 75

$\begin{array}{llll}", & \text { Extortions of } & 76 \\ \text { " } & \because & \text { Trial of } \quad \ldots & 77\end{array}$

Hawkins, Sir J̈onn $\quad$... $\quad$... 49

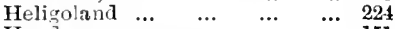

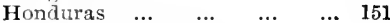

Hudson's Bay Company... $\quad$... 129

India, British Rule in ... $\quad \ldots \quad 51$

,, Governors-General of ... 107

,Transference to Crown... 88

$\begin{array}{lllll}\text { Indian Unrest } & \ldots & \ldots & \ldots & 100\end{array}$

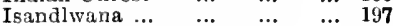

Jackson, Port, Settlement at 153

$\begin{array}{lllll}\text { Jamaica } & \ldots & \ldots & \ldots & 145,152\end{array}$

", Capture of $\quad \ldots \quad$... 145

". Slave Trade in ... $\quad \ldots . .146$ $\begin{array}{lllll}\text { Johannesbur } & \ldots & \ldots & \ldots & 212 \\ \end{array}$

$\begin{array}{lllll}\text { Kaffir Wars } & \ldots & \ldots & \ldots & 186\end{array}$

Kafferia, British ... $\quad \ldots . \quad \ldots .6192$

Farmatik, French in the... $\quad \ldots .60$

lieate Award, The $\quad \ldots . \quad \ldots .6205$

Krurer, President of Transvaal 208

Lagos ...

191,232

Lansdowne, $\begin{array}{lllll} & \ldots & \ldots & & \\ \text { Lord } & \ldots & \ldots & \ldots & 95\end{array}$

Laurier, Sil Wilfred $\quad \ldots . \quad \ldots . \quad 133$

Lawrenee, Sir John $\quad$... $\quad \ldots .99$

$\begin{array}{llllll}\text { Lexington } & \ldots & \ldots & \ldots & \ldots & 116\end{array}$

Loan, The Pepper... $\quad \ldots . \quad \ldots . \quad 54$

Lucknow, The siege of $\ldots . .6 . \quad \ldots .86$

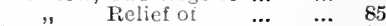

Lytton, Lord $\quad \ldots \quad \ldots . \quad \ldots .93$

Macdonald, Sir John $\quad \ldots \quad \ldots \quad 137$

Main, The Spanish $\quad \ldots . \quad \ldots .144$

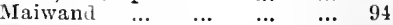

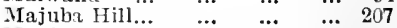

$\begin{array}{llllll}\text { Manitoba } & \ldots & \ldots & \ldots & \ldots & 132\end{array}$

Maories, Degeneration of $\quad \ldots .6170$

Maori King ...

$\begin{array}{lllll} & \text { Wars... } & . . & \ldots & 172,180\end{array}$

Märaetahi, Battle of $\quad \ldots . \quad \ldots r 1$

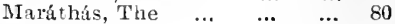

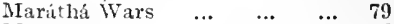

Maroons, The $\quad \ldots . \quad \ldots . \quad \ldots .146$

Maryland, Foundation of $\quad \ldots \quad 110$

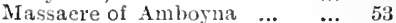

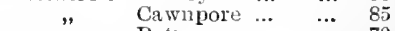

$\begin{array}{lllll}, & \text { Patna } & \ldots & \ldots & 70\end{array}$

Mrayfower, Voyage of The $\quad$... 110

$\begin{array}{lllll}\text { Mayo, Lord ... } & \ldots & \ldots & \ldots & 91\end{array}$

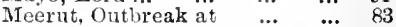

Merchants, Bristol, The ... $\quad \ldots .63$

Minto, Lord ... $\quad \ldots \quad$... $\quad \ldots \quad 100$

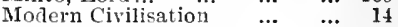

Morgan, Sir Henry $\quad$... $\quad \ldots .46$

Mutiny, The Indian $\quad \ldots .6 \quad \ldots .89$

Mysore Wars, The $\quad \ldots . \quad{ }^{74,78}$

Nana Sahib... $\quad \ldots \quad \ldots \quad$... 84

$\begin{array}{lllll}\text { Natal ... } & \ldots & \ldots & \ldots & 190,197\end{array}$

, Annexation of $\quad \ldots . \quad \ldots \quad 169$

$\begin{array}{lllll}\text { New Guinea... } & \ldots & \ldots & \ldots & 223\end{array}$

$\begin{array}{llllll}\text { New Spain } & \ldots & \ldots & \ldots & \ldots & 16\end{array}$

New Zealand $\quad \ldots . \quad \ldots . \quad 169,179$

" . $\quad$ Governors of $\quad \ldots \quad 183$

$\begin{array}{lllr}\text { Northbrook, Lord ... } & \ldots & \ldots & 93\end{array}$

North-IVest Passage $\quad \ldots . \quad \ldots \quad 42$

$\begin{array}{lllll}\text { Nora Seotia ... } & \ldots & \ldots & \ldots & \mathbf{1} 20\end{array}$

Navigators, The Early $\quad . . . \quad \ldots \quad 33$

$\begin{array}{llll}\text { Orange Free State } \quad \ldots & \ldots & 188\end{array}$

Oudah, Annexation of $\quad \ldots . \quad \ldots .68$

$\begin{array}{llll}\text { " } & \text { The Begams of } \quad \ldots & \ldots & 77\end{array}$

$\begin{array}{lllll}\text { Pahekas, The } & \ldots & \ldots & \ldots & 171\end{array}$

Patna, Massacre of $\quad \ldots . \quad \ldots .70$

Pitt and Canada, Scheme of Con. $\begin{array}{llllll}\text { quest } & \ldots & \ldots & \ldots & \ldots & 123\end{array}$ 


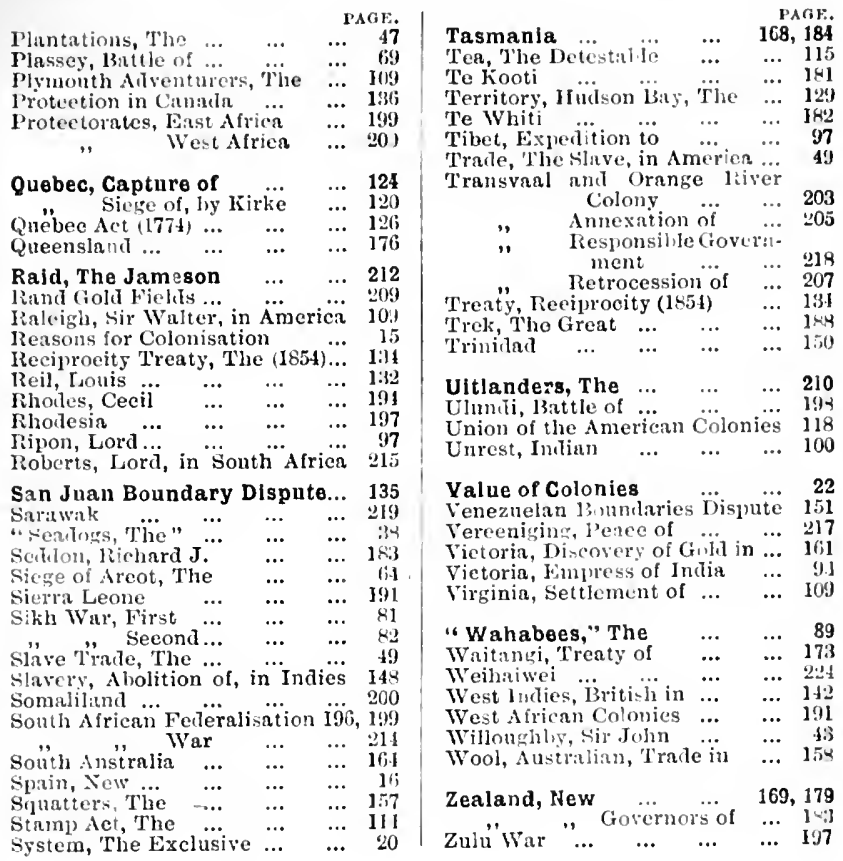

Printed by Hexiry Palsier \& Co., London. 


$$
\approx
$$




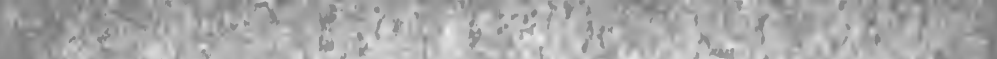

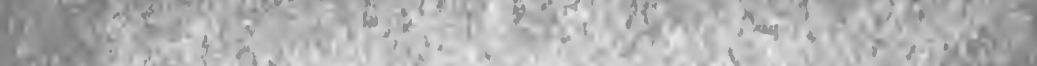
taxis

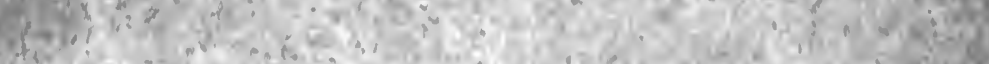

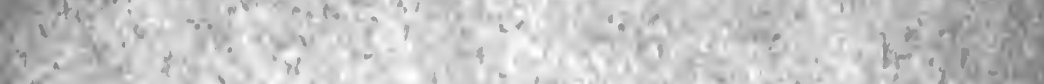

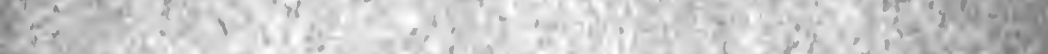
(2)

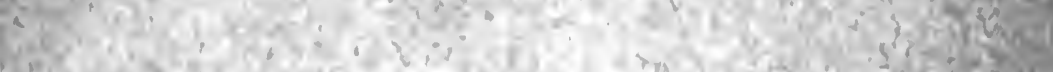

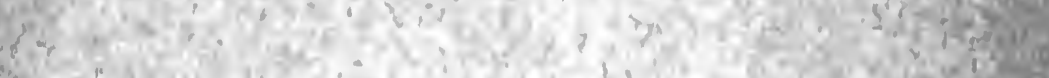

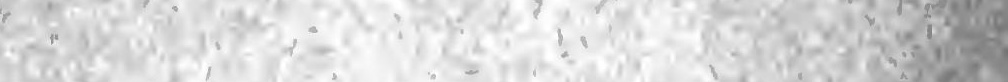

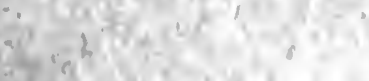
1) 18

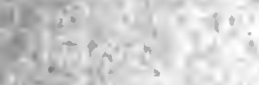

$x^{2}+1+$

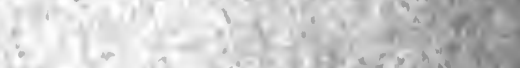

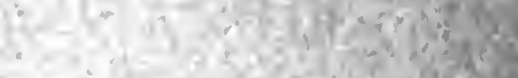

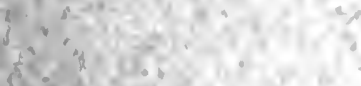

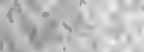
$y^{2} ;=$

r

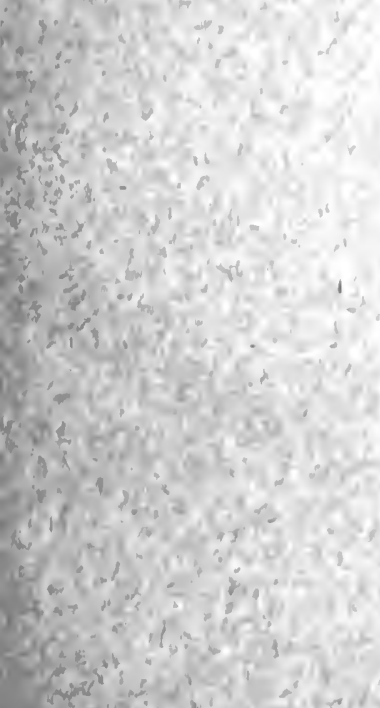


UNIVERSITY AF ILIF FORNIA LIBRARY

$r=$ 'igelt' 'es

date stamped below.

UNIVERSITY OF CALIFORNLA

AT

LOS ANGELES

LIBRARY 


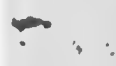




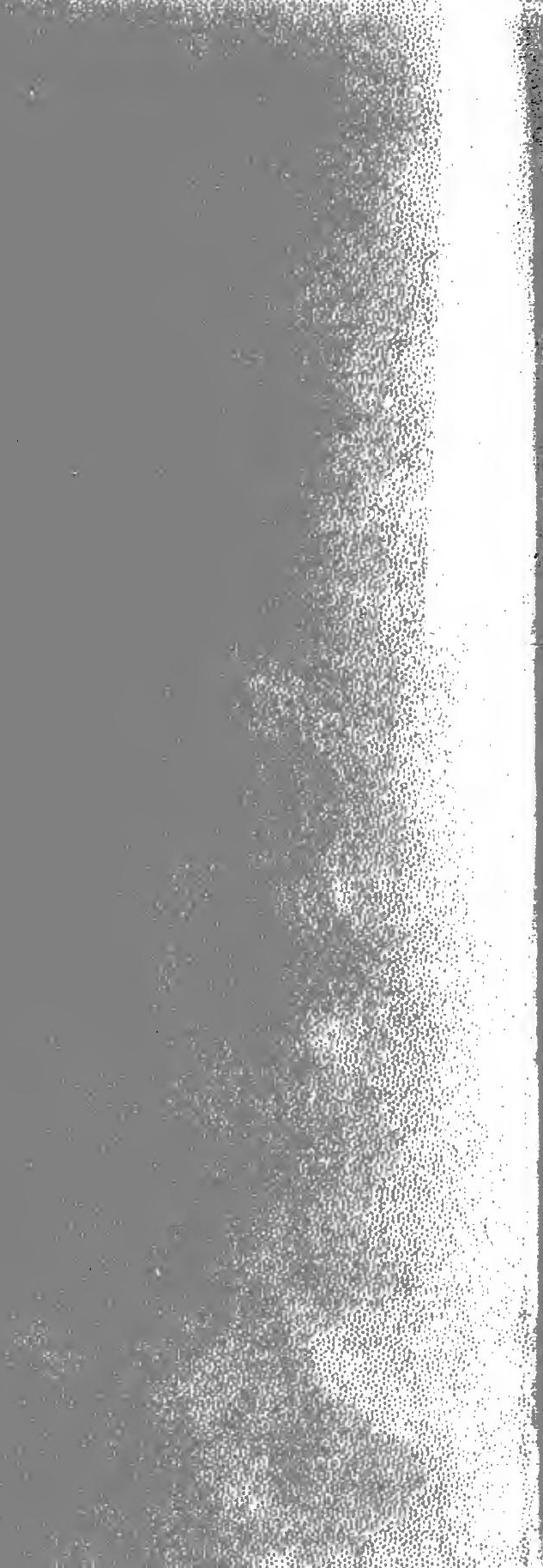

